\title{
Cist burials and an Iron Age settlement at Dryburn Bridge, Innerwick, East Lothian
}

\author{
by Andrew Dunwell \\ CFA Archaeology Ltd, The Old Engine House, Eskmills Park, \\ Station Road, Musselburgh EH21 7PQ \\ based upon excavation records and interim accounts produced by \\ Jon Triscott and David Pollock \\ with contributions by \\ B Finlayson, H E M Cool, T Cowie, \\ A Heald, F Hunter, D Ingemark, M Jay, J Roberts, \\ A Sheridan and J Thoms
}


Published by the Society of Antiquaries of Scotland, www.socantscot.org.uk with Historic Scotland, www.historic-scotland.gov.uk and the Council for British Archaeology, www.britarch.ac.uk

Editor Debra Barrie

Produced by Archetype Information Technology Ltd, www.archetype-it.com

ISBN: 0903903938

ISSN: $1473-3803$

Requests for permission to reproduce material from a $S A I R$ report should be sent to the Director of the Society of Antiquaries of Scotland, as well as to the author, illustrator, photographer or other copyright holder.

Copyright in any of the Scottish Archaeological Internet Reports series rests with the SAIR Consortium and the individual authors.

The maps are reproduced from Ordnance Survey material with the permission of Ordnance Survey on behalf of The Controller of Her Majesty's Stationery Office. CCrown copyright 2001. Any unauthorized reproduction infringes Crown copyright and may lead to prosecution or civil proceedings. Historic Scotland Licence No GD 03032G, 2002.

The consent does not extend to copying for general distribution, advertising or promotional purposes, the creation of new collective works or resale. 


\section{Contents}

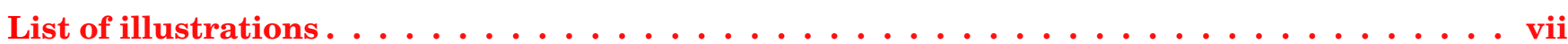

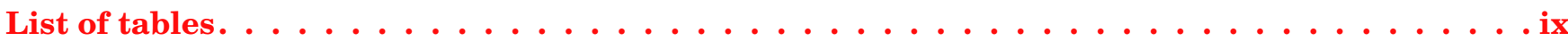

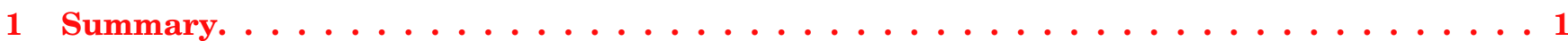

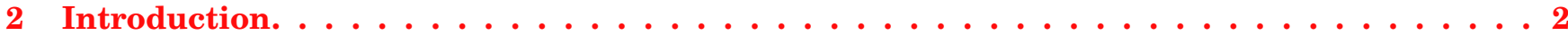

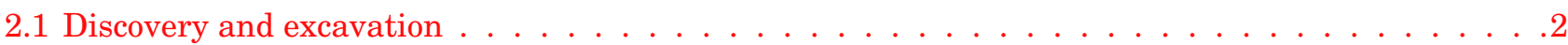

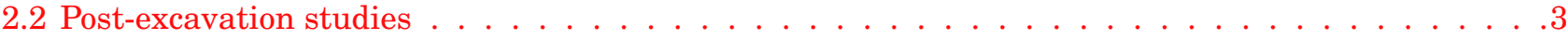

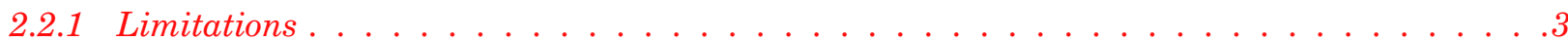

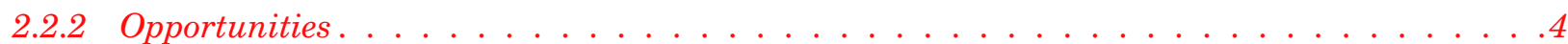

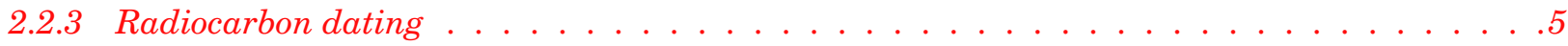

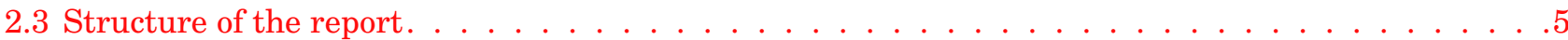

3 Early Prehistoric Activity: Excavation Results . . . . . . . . . . . . . . . 6

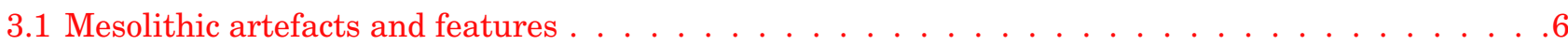

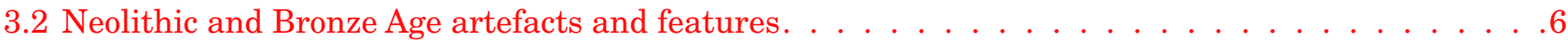

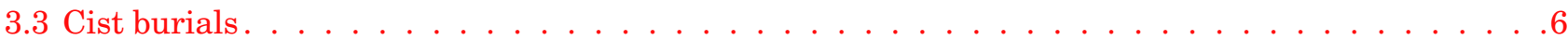

3.3 .1 Cist 1 (Burials 4 and 5$) \ldots \ldots \ldots \ldots \ldots \ldots \ldots \ldots \ldots \ldots \ldots \ldots \ldots \ldots \ldots . \ldots \ldots \ldots$

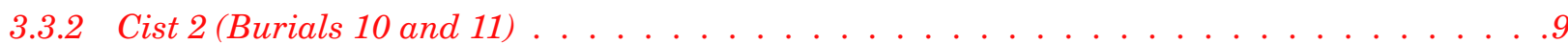

4 Early Prehistoric Activity: The Finds . . . . . . . . . . . . . . . . . . . . . 12

4.1 Chipped stone by Bill Finlayson . . . . . . . . . . . . . . . . . . . . . . . . 12

4.2 Late Neolithic pottery by Hilary Cool \& Trevor Cowie . . . . . . . . . . . . . . . . . . . . . . . . 12

4.3 Beaker vessel by Alison Sheridan. . . . . . . . . . . . . . . . . . . . . . . . . . 14

4.4 Human remains from the cists by Julie Roberts . . . . . . . . . . . . . . . . . . . . . . . . . . . 18

4.4 .1 Introduction . . . . . . . . . . . . . . . . . . . . . 18

4.4 Preservation . . . . . . . . . . . . . . . . . . . . . 19

4.4 .3 Age at death and sex . . . . . . . . . . . . . . . . . . . . . . 19

4.4 .4 Cranial metric data . . . . . . . . . . . . . . . . . . . . . . . . . . . . . 19

4.4 .5 Post-cranial metric data . . . . . . . . . . . . . . . . . . . . . . 20

4.4 .6 Non-metric data . . . . . . . . . . . . . . . . . . . . . . . 20

4.4 .7 Health and disease . . . . . . . . . . . . . . . . . . . . . . . . 21

4.4 .8 Burial catalogue . . . . . . . . . . . . . . . . . . . . . . . . 24

5 Early Prehistoric Activity: Radiocarbon Dates from the Human Remains . . . . . . . . . 26

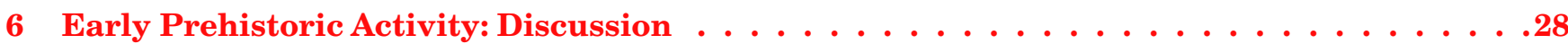

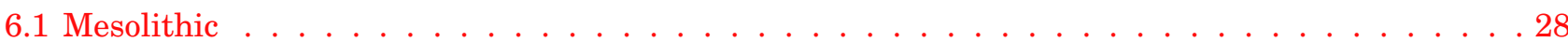

6.2 Late Neolithic/Early Bronze Age . . . . . . . . . . . . . . . . . . . . . . . . . 28

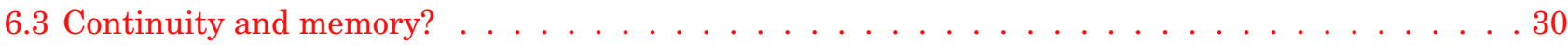


7 The Iron Age Settlement: Excavation Results $\ldots \ldots \ldots \ldots \ldots$

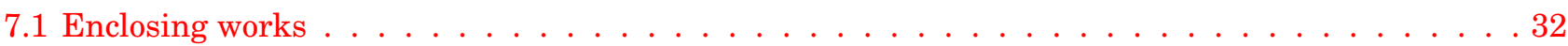

7.1 .1 Outer enclosure. . . . . . . . . . . . . . . . . . . . . 32

7.1.2 Possibly related external works . . . . . . . . . . . . . . . . . . . . . 34

7.1 .3 Inner enclosure . . . . . . . . . . . . . . . . . . . . . . . . . 35

7.1.4 Relationship between the two enclosing works . . . . . . . . . . . . . . . 35

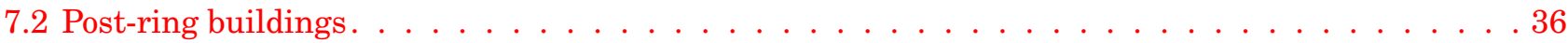

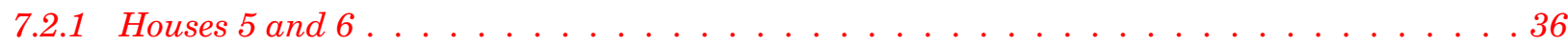

7.2 .2 House 1. . . . . . . . . . . . . . . . . . . . . . . . . . . . . . . . . . . . . . .

7.2 .3 House 4. . . . . . . . . . . . . . . . . . . . . . . . . . . 42

7.2 .4 House 10?. . . . . . . . . . . . . . . . . . . . . . . .44

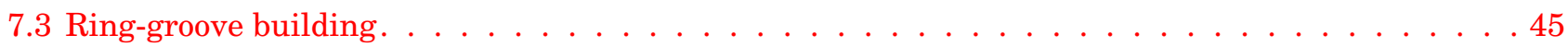

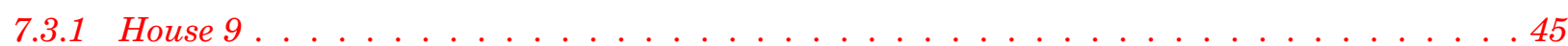

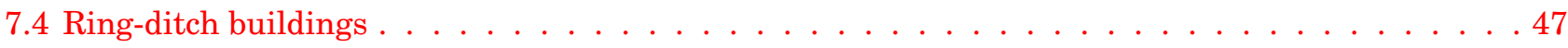

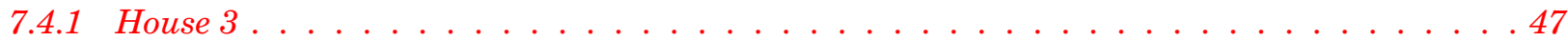

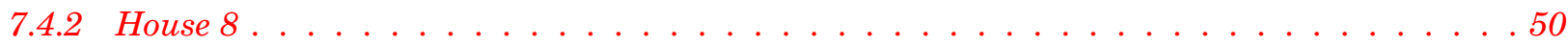

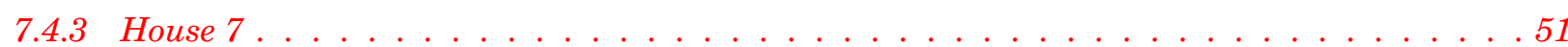

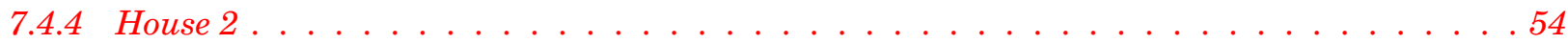

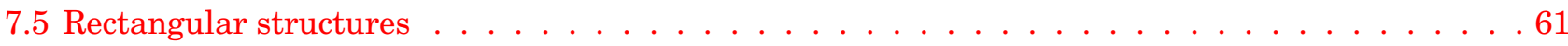

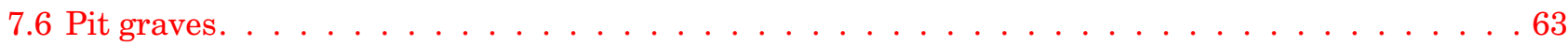

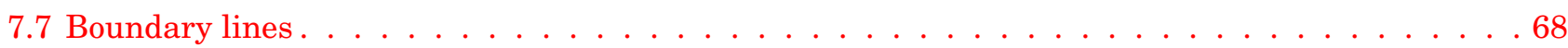

7.7.1 Fence-line associated with House $7 \ldots \ldots$. . . . . . . . . . . . 68

7.7 .2 Pitted boundaries articulating with House 8 porch . . . . . . . . . . . . . . . . 68

7.7.3 Pitted boundary north-west of House 7? . . . . . . . . . . . . . . . . . . . 69

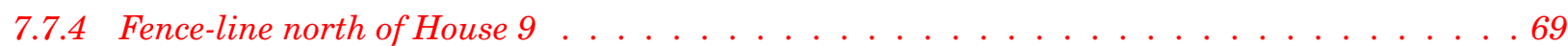

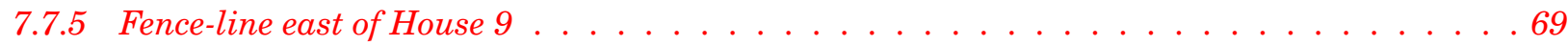

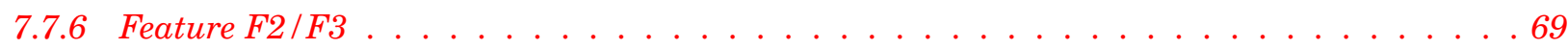

7.7 .7 Feature O36. . . . . . . . . . . . . . . . . . . . . . 669

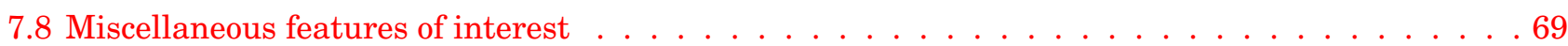

7.8.1 Feature M69 and intercutting remains . . . . . . . . . . . . . . . . 69

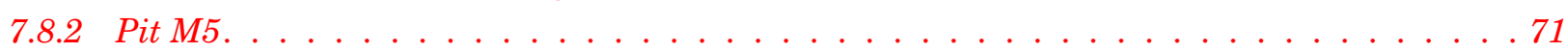

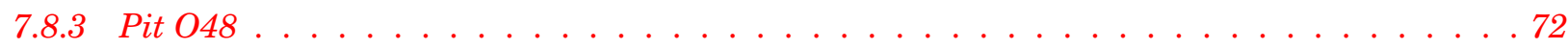

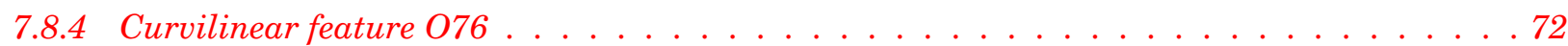

8 The Finds from the Iron Age Settlement $\ldots \ldots \ldots \ldots \ldots \ldots \ldots$

8.1 Pottery by Hilary Cool . . . . . . . . . . . . . . . . . . . . . . . . . . . . . . . . . . . . .73

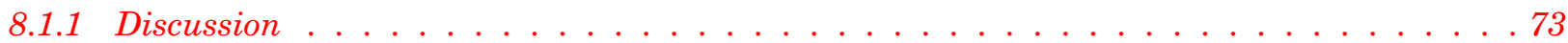

8.1 .2 Catalogue of illustrated forms . . . . . . . . . . . . . . . . . . . . . 74

8.2 Coarse stone tools by Hilary Cool . . . . . . . . . . . . . . . . . . . . . . . . . . . .75

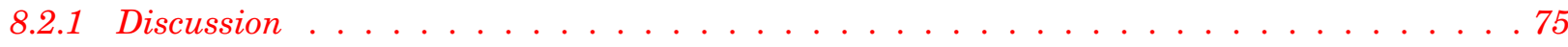

8.2 .2 Catalogue of illustrated coarse stone artefacts . . . . . . . . . . . . . . . . . 77

8.3 Copper alloy by Fraser Hunter . . . . . . . . . . . . . . . . . . . . . . . . . . 78

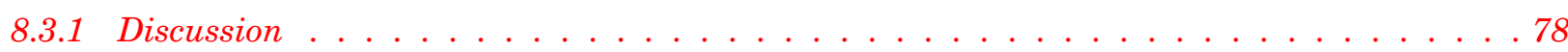

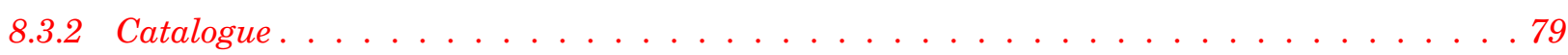

8.4 Iron by Fraser Hunter . . . . . . . . . . . . . . . . . . . . . . . . . . . . . . . . . . . . 79

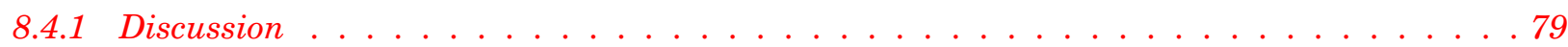

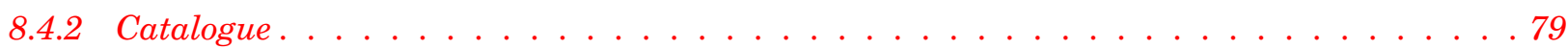

8.5 Roman glass by Dominic Ingemark . . . . . . . . . . . . . . . . . . . . . 80 


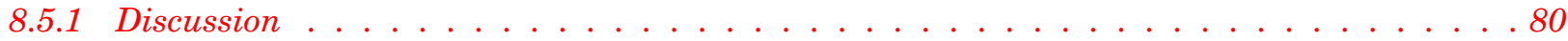

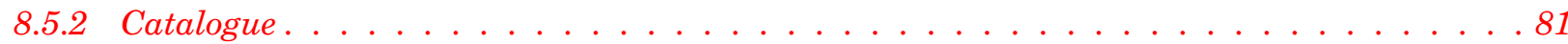

8.6 Oil shale and cannel coal by Fraser Hunter. . . . . . . . . . . . . . . . . . . . . . . . . . 81

8.6 .1 Discussion . . . . . . . . . . . . . . . . . . . .81

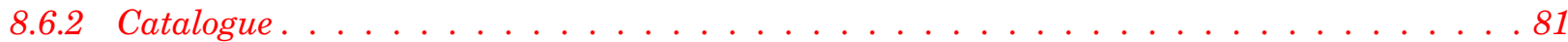

8.7 Slag by Andrew Heald . . . . . . . . . . . . . . . . . . . . . . . . . . . . . . . . . . .81

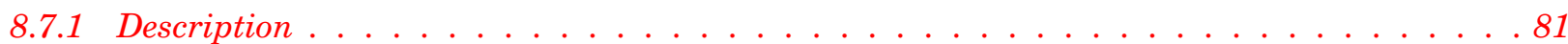

8.7 .2 Discussion . . . . . . . . . . . . . . . . . . . . 82

8.8 Antler by Fraser Hunter . . . . . . . . . . . . . . . . . . . . . . . . . . . . . 82

8.9 Discussion of the artefact assemblage by Fraser Hunter . . . . . . . . . . . . . . . . . . . . 83

8.9 .1 Nature of the assemblage. . . . . . . . . . . . . . . . . . . . . . . 83

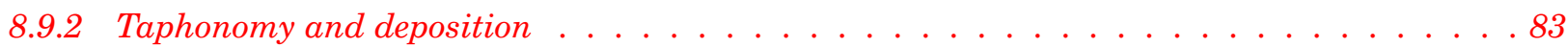

8.9 .3 Regional patterns. . . . . . . . . . . . . . . . . . . . . 84

9 Faunal and Human Remains from the Iron Age Settlement . . . . . . . . . . . . . . .86

9.1 Animal bone by Jennifer Thoms. . . . . . . . . . . . . . . . . . . . . . . . . 86

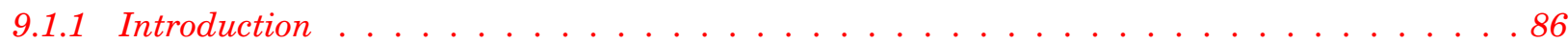

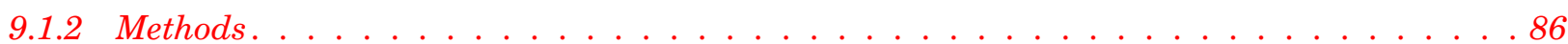

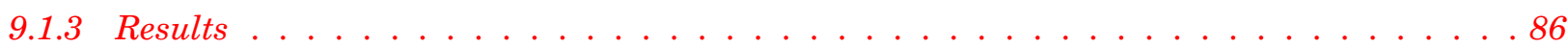

9.1 .4 Outer enclosure palisade trench . . . . . . . . . . . . . . . . . . . . .86

9.1.5 Inner enclosure palisade trench . . . . . . . . . . . . . . . . . . . 86

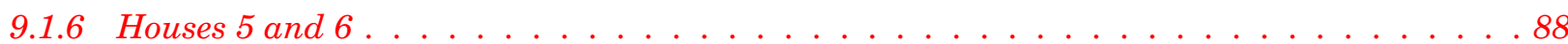

9.1 .7 House $7 \ldots \ldots \ldots \ldots \ldots \ldots \ldots$

9.1 .8 House 2. . . . . . . . . . . . . . . . . . . . .88

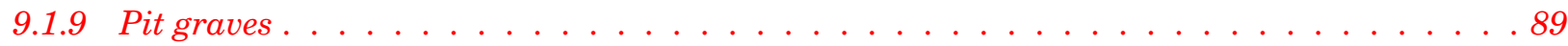

9.1 .10 Pitted boundaries articulating with House 8 porch . . . . . . . . . . . . . . . . . . . . 89

9.1 .11 M69 and $d o g$ burial (M43) . . . . . . . . . . . . . . . . . . . . . .90

9.1 .12 Pit $048 \ldots \ldots \ldots$. . . . . . . . . . . . . . . . . . . . . . 90

9.1 .13 Conclusion . . . . . . . . . . . . . . . . . . . . .91

9.2 Human remains from the pit graves by Julie Roberts . . . . . . . . . . . . . . . . . . . . . .91

9.2 .1 Introduction . . . . . . . . . . . . . . . . . . . . . .91

9.2 .2 Age at death and sex . . . . . . . . . . . . . . . . . . . . . . . . . . . . . . . . .

9.2 .3 Metric data . . . . . . . . . . . . . . . . . . . . . . . . . . . .92

9.2 .4 Health and disease . . . . . . . . . . . . . . . . . . . . . . . . . 92

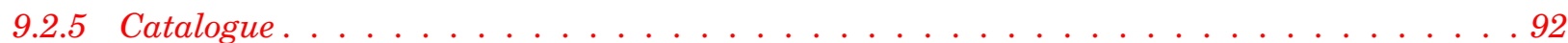

9.3 Stable isotopes from the human and faunal remains by Mandy Jay . . . . . . . . . . . . . . . . 93

10 Radiocarbon Dates from the Iron Age Settlement. . . . . . . . . . . . . . . . . . .96

11 The Iron Age Settlement: Discussion $\ldots \ldots \ldots \ldots \ldots \ldots \ldots$

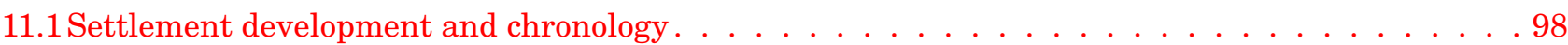

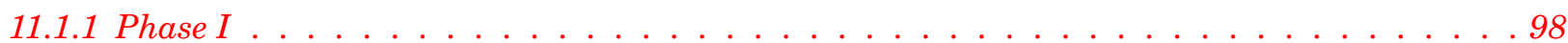

11.1 .2 Phase II . . . . . . . . . . . . . . . . . . . . . . . . . . . 100

11.1 .3 Phase III . . . . . . . . . . . . . . . . . . . . . . . . . . . . . . . . . . . . 101

11.1.4 From enclosed to unenclosed settlement - between Phases II and III . . . . . . . . . . . 102

11.1.5 Population growth/settlement expansion . . . . . . . . . . . . . . . . . . . . 102

11.2 The palisaded (outer) enclosure . . . . . . . . . . . . . . . . . . . . . 103

11.3 Roundhouses . . . . . . . . . . . . . . . . . . . . . . . . . . 103 
11.3.1 Post-ring structures. . . . . . . . . . . . . . . . . . . . . . . . 103

11.3.2 Ring-ditch buildings . . . . . . . . . . . . . . . . . . . . . . . 103

11.3.3 Ring-groove construction. . . . . . . . . . . . . . . . . . . . . . . . . 104

11.3.4 Houses as cultural and chronological indicators? . . . . . . . . . . . . . . . . . . . 104

11.3.5 Orientations and cosmology . . . . . . . . . . . . . . . . . . . . . . . . 104

11.4 Rectangular structures. . . . . . . . . . . . . . . . . . . . . . 105

11.5 Souterrain-related features . . . . . . . . . . . . . . . . . . . . 105

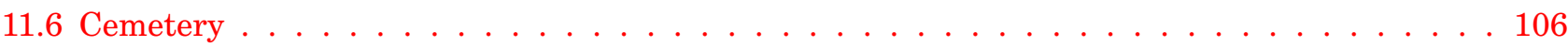

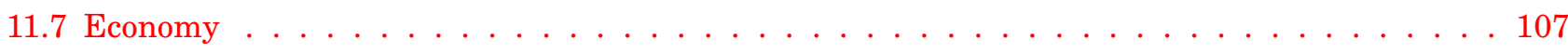

11.8 Wealth and status of the settlement. . . . . . . . . . . . . . . . . . 107

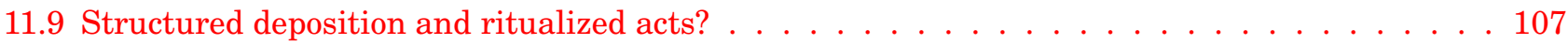

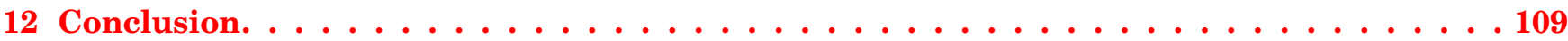

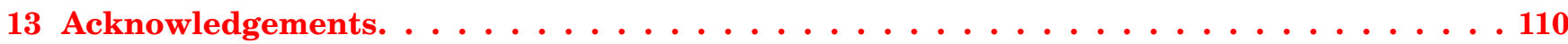

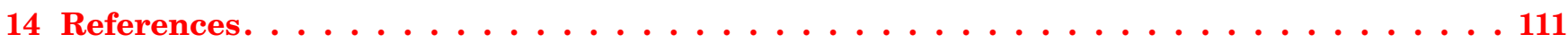

Appendix I: Osteoarchaeological Analysis Methodology . . . . . . . . . . . . . . . 117 


\section{List of Illustrations (all Crown copyright: Historic Scotland unless otherwise stated)}

Location maps; showing distribution of other archaeological sites in the vicinity mentioned in the text: 1, West Pinkerton cist; 2, East Barns cist; 3, Skateraw 1 cist; 4, Skateraw 3 cist; 5, Skateraw 2 cist; 6, Dryburn; smaller palisaded enclosure . . . . . . . . . . . . . . . . .2 Aerial photograph of site during excavation; from the north-east. (CCrown copyright:

RCAHMS; $\operatorname{ref} 4061 / \mathrm{CN}) \ldots \ldots \ldots \ldots \ldots \ldots \ldots$

Site plan; with principal excavated structures and features highlighted . . . . . . . . . . . . . .

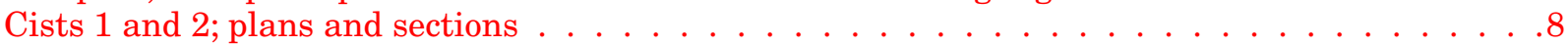

Cist 1 ; showing disturbed capstones; from south-west . . . . . . . . . . . . . . . . 9

Cist 1 ; showing Burials 4 and 5 ; from north-east. . . . . . . . . . . . . . . .

Cist 2; showing capstone overlain by flat slabs; and Beaker vessel; from west . . . . . . . . . . 10

Cist 2 ; showing Burials 10 and 11 ; from west. . . . . . . . . . . . . . . . . . 11

Late Neolithic Impressed Ware . . . . . . . . . . . . . . . . . . . . . . 13

Beaker from above Cist $2 \ldots \ldots \ldots \ldots \ldots$

Reconstructed Beaker; overhead view . . . . . . . . . . . . . . . . . . 15

Reconstructed Beaker; 'narrow side' view. . . . . . . . . . . . . . . . . . . . . 16

Reconstructed Beaker; "broad side' view. . . . . . . . . . . . . . . . . . . . . . . 17

Radiocarbon dates for Scottish Beakers (courtesy of Alison Sheridan). . . . . . . . . . . . . 18

Burial 11; widening and remodelling of nasal aperture; and resorption of the alveolar process

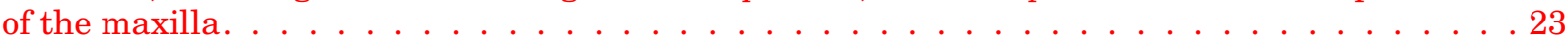

Burial $11 ;$ rhino-maxillary changes in profile. . . . . . . . . . . . . . . 23

Looking east towards inner enclosure entrance in foreground and outer enclosure north-east

entrance in background . . . . . . . . . . . . . . . . . . . . . . . 32

Inner enclosure entrance and outer enclosure north-east entrance; plan . . . . . . . . . . . . . 33

Outer enclosure east side; with south-east entrance in foreground . . . . . . . . . . . . . . . 34

Inner enclosure; sample section of palisade trench. . . . . . . . . . . . . . . . . . 35

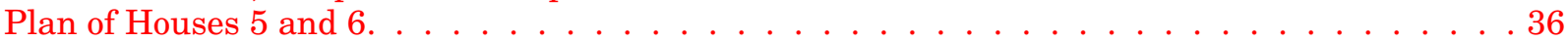

House 5 photograph from the west . . . . . . . . . . . . . . . . . 37

House 6 photograph from the north-west looking along the entrance passage in the

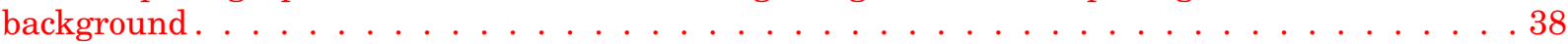

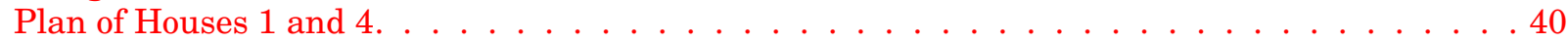

$25 \quad$ House 1; from south-east looking along its entrance passage with the inner enclosure

boundary in the background. . . . . . . . . . . . . . . . . . . . . 41

Linear features on the west side of House 1; and post B84. Feature B91 is visible fully

excavated behind the scale bar . . . . . . . . . . . . . . . . . . . . 41

House 4 as first revealed; from the south-west . . . . . . . . . . . . . . . . . . 43

House 4 as excavated; from the south-west. . . . . . . . . . . . . . . . . . 43

Plan of putative House 10 and rectangular structure $\mathrm{H} \ldots \ldots \ldots \ldots \ldots$

House 9 plan . . . . . . . . . . . . . . . . . . . . . . . 46

House 9 during excavation; from south-west; the sections of ring-groove detected only as

drying marks are not visible on this shot . . . . . . . . . . . . . . . 46

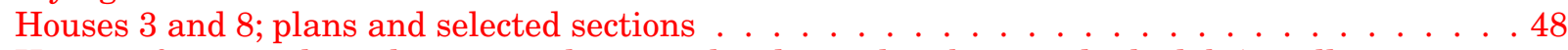

33 House 3 from south; with outer enclosure palisade overlain by ring-ditch slab (see illus

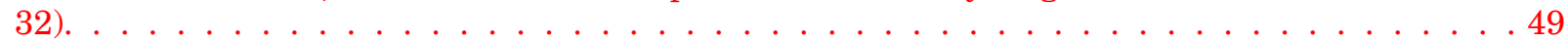

$34 \quad$ House 3; as excavated; showing slightness of ring-ditch and porch post F6 truncating linear

feature F2 (illus $3 ; f$ ) in foreground . . . . . . . . . . . . . . . . . . . . 49

House 8 ; detail of paving within ring-ditch; from south $\ldots \ldots \ldots \ldots$

House 7 ; plan. . . . . . . . . . . . . . . . . . . . . . . 52

House 7; showing variable depth of soil overlying foundations; from north-east . . . . . . . . 53

House 7; showing excavated foundations and entrance structure; and feature K2. The sheep

burial in the foreground is considered to be a modern; intrusive feature . . . . . . . . . . . . 53

House 2 ; plans showing foundation features; and phase plans . . . . . . . . . . . . 55

House 2 ; selected sections . . . . . . . . . . . . . . . . . . . . . 56

House 2; as initially uncovered; from east showing scoop filled with post-abandonment

infill and band of hillwash CAC in foreground from east . . . . . . . . . . . . . . 57 
House 2; showing section of cobble deposit filling the ring-ditch and sealing the inner

ring-groove (with packing stones still in situ) in north-west quad; from south-west . . . . . . . .58

House 2 ; showing paving overlying cobble infill of ring-ditch; from south-east . . . . . . . . . 58

House 2 ; detail of paving sealed beneath abandonment deposits . . . . . . . . . . . . . . . 59

House 2; the late curving ditched feature cutting through the cobble fill of the ring-ditch;

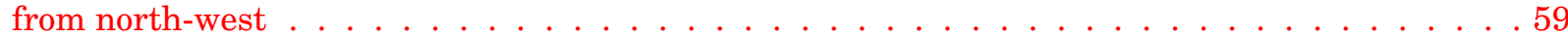

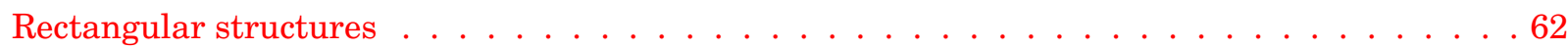

Iron Age pit burials; plans and sections. . . . . . . . . . . . . . . . . . . . . 64

49

Burial 1; cut across partly excavated outer enclosure palisade; from south-west. . . . . . . . . 66

Burial 7 and palisade trench; half-section; with partly excavated outer enclosure palisade

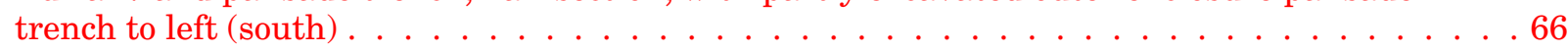

51 Burial 13; showing preserved human remains; with outer enclosure palisade packing

partially visible top right . . . . . . . . . . . . . . . . . . . . 67

Burial 14; truncating outer enclosure palisade (with packing left in situ); from north-west . . . . 67

Feature M69; showing excavated profile; from east . . . . . . . . . . . . . . . . . . 70

Stone-lined pit M5 . . . . . . . . . . . . . . . . . . . . . . . 71

Pit $\mathrm{O} 48$ showing partly exposed antler . . . . . . . . . . . . . . . . . . . . . 71

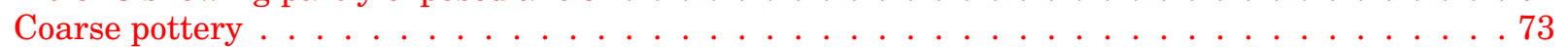

Selected saddle-querns . . . . . . . . . . . . . . . . . . . . . . 75

Other coarse stone items . . . . . . . . . . . . . . . . . . . . . 76

Copper alloy and iron objects . . . . . . . . . . . . . . . . . . . 78

Glass and oil shale objects. . . . . . . . . . . . . . . . . . . . . . . . 80

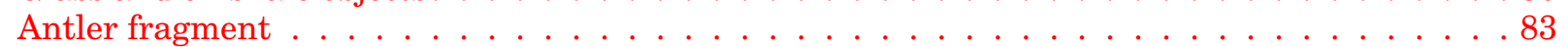

Stable isotope values plotted for individual humans and fauna . . . . . . . . . . . . . . 94

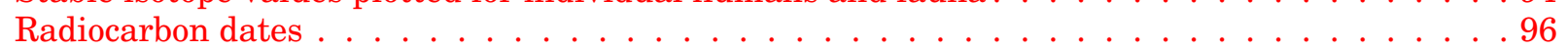




\section{List of Tables}

1 Composition of the chipped stone assemblage . . . . . . . . . . . . . . . . 12

2 Summary of ages at death and sex of burials from cists . . . . . . . . . . . . . . . 19

3 Cranial measurements of the adult skeletons from the cists . . . . . . . . . . . . . . 19

4 Post-cranial metric data for the skeletons from the cists . . . . . . . . . . . . . . . 20

5 Average British male height through time . . . . . . . . . . . . . . . . . . 20

6 Radiocarbon dates from Cists 1 and $2 ; 1979 / 1980$. . . . . . . . . . . . . . . . . . . . 26

7 Radiocarbon dates from Cists 1 and $2 ; 2005$. . . . . . . . . . . . . . . . . . . . . 26

8 Radiocarbon dates from House 9 . . . . . . . . . . . . . . . . . . . . . . . . . 47

9 Radiocarbon dates from House 2 . . . . . . . . . . . . . . . . . . . . . 61

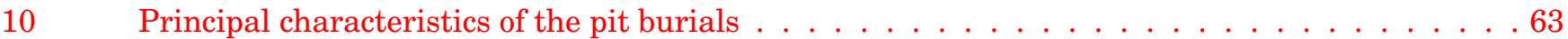

11 Radiocarbon dates from the pit burials . . . . . . . . . . . . . . . . . . 65

12 Summary of coarse stone assemblage. . . . . . . . . . . . . . . . . . . . . 77

Distribution of slag. . . . . . . . . . . . . . . . . . . . . . . . . . . .82

Distribution of finds at Dryburn Bridge (excluding features with few finds) . . . . . . . . . . . . 84

The animal bone retrieved from various features at Dryburn Bridge. . . . . . . . . . . . . . 87

Fragmentation and preservation of animal bone. . . . . . . . . . . . . . . . . . . 89

Summary of ages of death and sex of Iron Age burials. . . . . . . . . . . . . . . . . . . . . 91

Isotopic results for human samples . . . . . . . . . . . . . . . . . . . . . . . . . . . 94 


\section{Summary}

This report provides an account of the excavations of a cropmark enclosure and other prehistoric remains at Dryburn Bridge, near Innerwick in East Lothian. The excavations were directed over two seasons in 1978 and 1979 by Jon Triscott and David Pollock, and were funded by the Ancient Monuments Branch, Scottish Development Department. Features and artefacts of various periods were discovered during the excavations, including a Mesolithic chipped stone assemblage and pits associated with Impressed Ware pottery. A pair of distinctive burial cists dating to $c$ 2300-2000 cal BC was discovered, each containing two inhumations, one articulated and the other disarticulated; a Beaker vessel was found directly above one of the cists. By the mid first millennium cal BC a settlement had been founded on the site. Three successive settlement layouts can be interpreted from the excavated structures. The first two phases represent continuous occupation, dating to before $400 \mathrm{cal} \mathrm{BC}$, and consisted of timber roundhouses, other rectangular structures and a small cemetery of pit graves located within a palisaded enclosure. The final occupation phase, which extended into the Roman Iron Age and may have occurred after a break in occupation, consisted of an unenclosed settlement of ring-ditch houses. Historic Scotland and predecessor bodies funded the post-excavation studies and publication of this report. 


\section{Introduction}

\subsection{Discovery and excavation}

This report provides an account of the excavations of a cropmark enclosure and other prehistoric remains at Dryburn Bridge, near Innerwick in East Lothian (NT 724 755; illus 1). The excavations were directed over two seasons in 1978 and 1979 by Jon Triscott and David Pollock, and were funded by the Ancient Monuments Branch, Scottish Development Department (now Historic Scotland). A summary statement of results was published in the Proceedings of the Prehistoric Society (Pollock \& Triscott 1980), and an

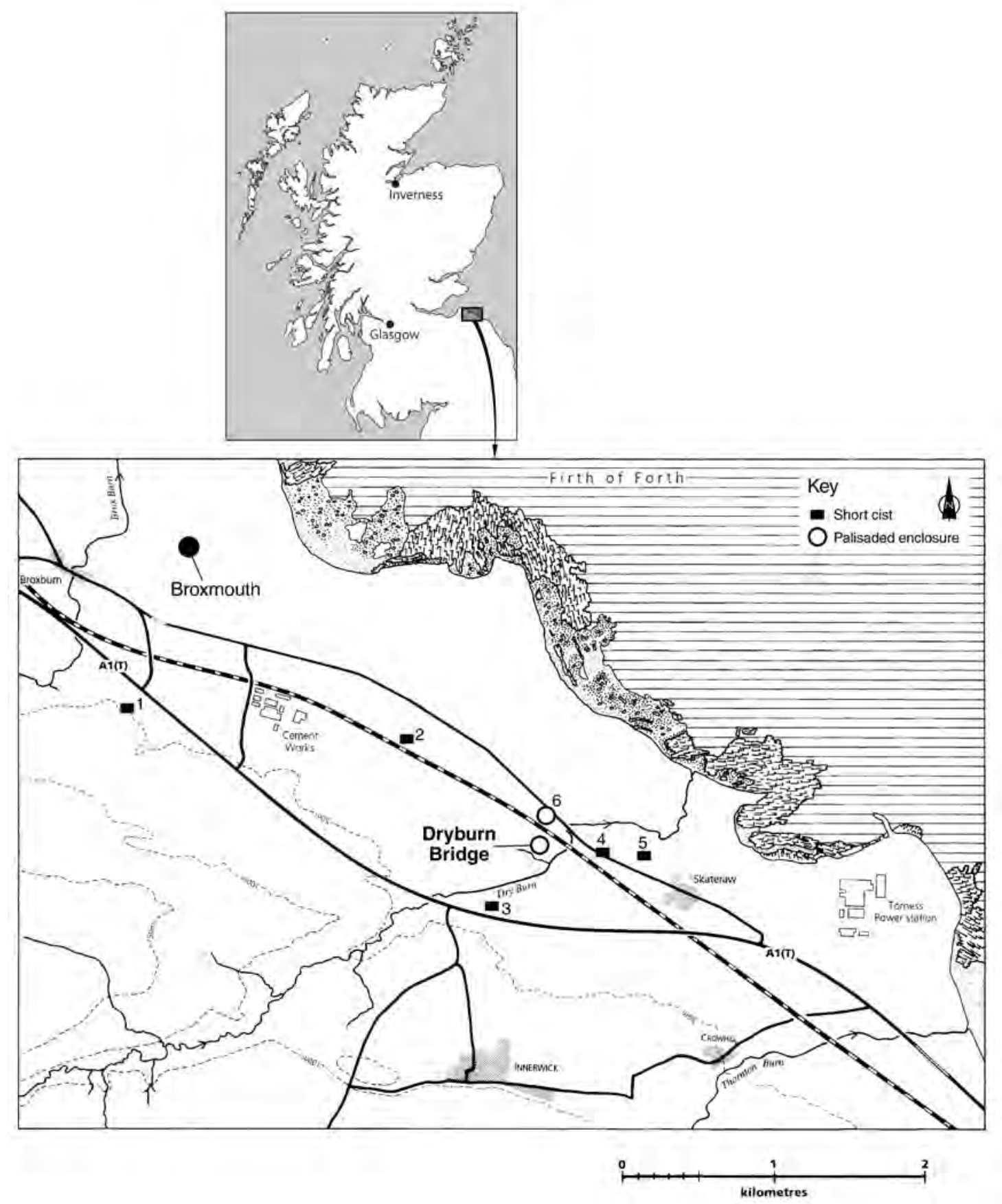

Illus 1 Location maps; showing distribution of other archaeological sites in the vicinity mentioned in the text: 1, West Pinkerton cist; 2, East Barns cist; 3, Skateraw 1 cist; 4, Skateraw 3 cist; 5, Skateraw 2 cist; 6 , Dryburn; smaller palisaded enclosure 
interim report was published in an edited volume on the later prehistoric settlement of south-east Scotland (Triscott 1982). Historic Scotland subsequently commissioned the Centre for Field Archaeology, University of Edinburgh and latterly CFAArchaeology Ltd (CFA), to undertake the production of this final excavation report. The directors of the excavations were made aware of these arrangements by Historic Scotland.

The site at Dryburn Bridge is situated $c 5.5 \mathrm{~km}$ south-east of Dunbar and $c 1 \mathrm{~km}$ from the North Sea coast, immediately to the south of the East Coast railway line (illus 1 ). It lies on a low ridge of banded glacial outwash sands and gravels on the north side of the Dry Burn. Its locality contains a dense distribution of recorded prehistoric sites, and evidently formed an attractive area for early settlement.

The site was discovered in 1974 as cropmarks on aerial photographs taken by Fairey Survey Ltd (Ref: 20/986-91) during an aerial survey of the Dunbar coastal strip. Those photographs reveal an elongated oval enclosure defined by a palisade trench and measuring $c 90 \mathrm{~m}$ by $50 \mathrm{~m}$. At least one circular structure is visible within the enclosure on those photographs, together with a small circular cropmark outside the palisade to the south-west.

The site was excavated as a result of the threat posed to it by limestone quarrying operations.
The first season of excavation took place between October and December 1978, and was designed as a large-scale trial to assess the archaeological potential of the site. This comprised the investigation of the northern half of the enclosure. Following this, excavation continued between April and July 1979, exposing the whole of the enclosure and adjacent areas, with the aim of recording the structural evidence located (illus 2). Plough-truncation was noted to have been relatively severe (Triscott 1982,119 ), with at least $0.3 \mathrm{~m}$ of the subsoil having been removed across most of the interior of the enclosure, increasing to as much as $1 \mathrm{~m}$ to the north and south-east, where the preservation of archaeological remains was much reduced.

In 2004 , when the author visited the site, limestone quarrying had encroached into the west side of the excavation site, although much of the site area remained intact.

\subsection{Post-excavation studies}

\subsubsection{Limitations}

There are inevitable drawbacks to excavation reports being compiled belatedly by a third party with no

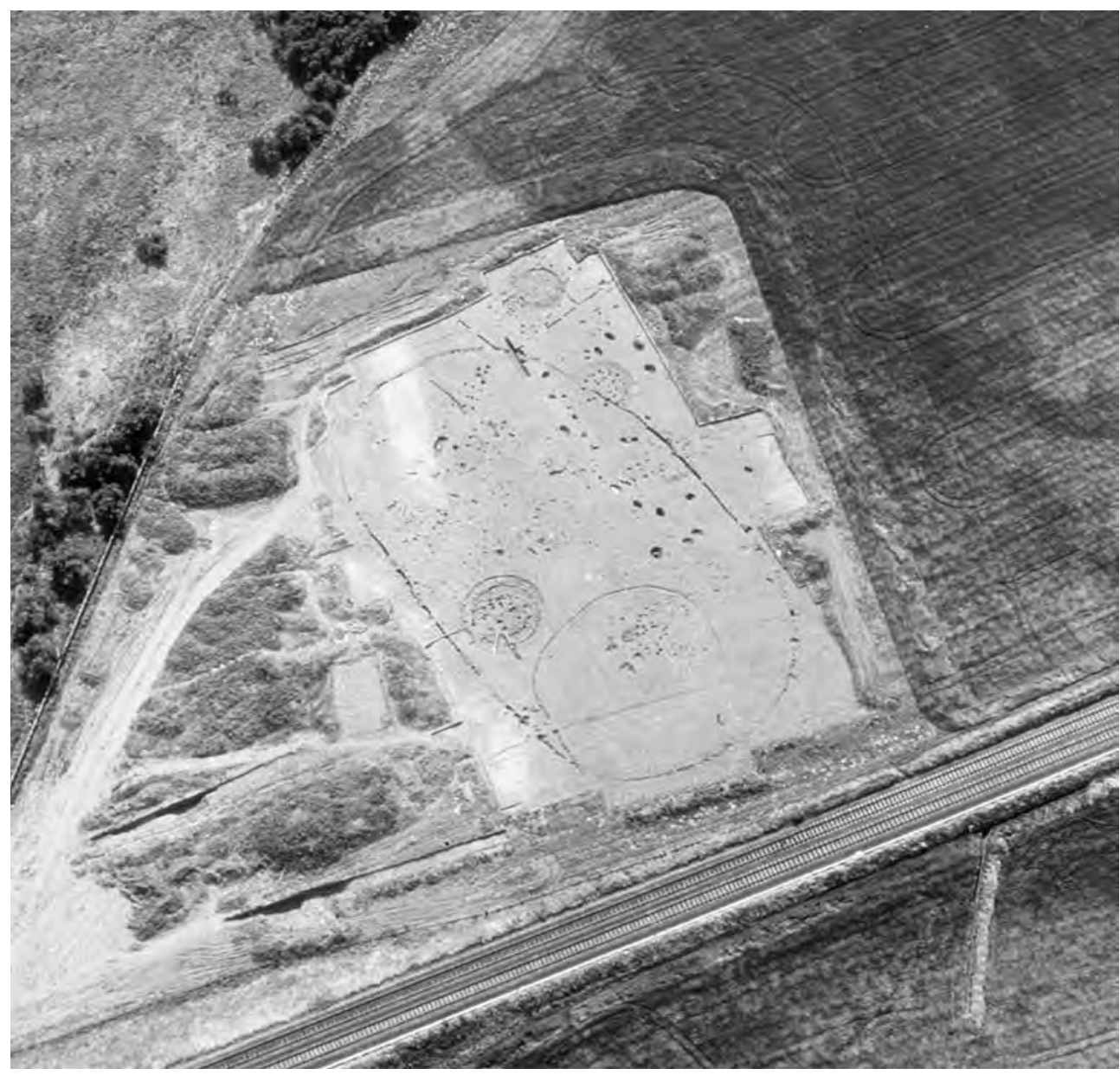

Illus 2 Aerial photograph of site during excavation; from the north-east. (CCrown copyright; RCAHMS; ref $4061 / C N)$ 
first-hand experience of the site, owing to the distance between the author and the source data. In the case of Dryburn Bridge, however, this problem is considerably mitigated by the excellent site archive loaned to CFA by the National Monuments Record of Scotland (NMRS). The site records include site diaries, context record forms, field drawings and interpretative inked drawings, a monochrome photograph record and a variety of concordance lists. To allow cross-reference between this report and the archive, the original context and feature numbers are retained, although their use is restricted to the minimum necessary to describe the key features of the site.

Unfortunately, the archive does not contain a concordance list between small finds numbers and context codes. Much of this information could be retrieved from specialist reports and individual context records; however, much of the chipped stone assemblage (Section 4.1) is not catalogued in the context records, and the small finds numbers on the finds bags cannot be linked to specific contexts. While this is regrettable, as one large collection of material which appears to have come from the same feature cannot be provenanced, it does not significantly detract from the interpretation of the site as a whole.

At the time of writing (2006) most of the artefactual material is housed at the National Museums of Scotland (NMS). However, the whereabouts of the prehistoric pottery, apart from the Beaker vessel, and some of the coarse stone items are unknown, despite an extensive search. Specialist reports and finds illustrations were produced for some of the materials in the years around 1980. Hilary Cool examined the pottery (apart from the Beaker vessel) and coarse stone tools, and Mary Harman analysed the human and animal bone assemblages. During this final phase of report preparation the human and faunal remains have been re-examined, by Julie Roberts and Jennifer Thoms respectively, to take into account considerable research advances in these subject areas over the last two decades. Mary Harman's reports are contained within the site archive. Hilary Cool's reports are included here, as the absence of much of the material did not permit meaningful re-analysis. The absence of a proportion of this material is to be regretted because, as noted by Hilary Cool (pers comm in 2000 to D Alexander) in relation to the pottery report, the research questions asked of later prehistoric artefact assemblages have moved on considerably. These developments have occurred both through methodological advances and through the development of different paradigms as to how the deposition of artefact assemblages on later prehistoric settlement sites across Britain can be understood (eg Hunter 1996 and Hunter 1997 for the Iron Age in northern Britain). The various other artefact materials do not appear to have been considered around 1980, and were examined for the first time as part of this final phase of work.

The excavations pre-dated the practice of routine soil sampling and sample processing for the recovery of palaeoenvironmental materials ( $\mathrm{R}$ McCullagh, pers comm), and as a result much ecofactual material was probably not recovered.

In the following account the descriptions of, and stratigraphic relationships between, excavated features follow those proposed by the excavators except where otherwise stated following interrogation of the site records by the author, on the understanding that the authors of the site records were closer to the source data. Any errors in interpretations made beyond those of the excavators are solely the responsibility of the present author.

\subsubsection{Opportunities}

The delay between the completion of the Dryburn Bridge excavation and the final publication of its results has had some unintended benefits. These derive from the considerable paradigm shift which developed during the 1990s as to how we should understand Iron Age societies and interpret the physical remains of their settlements and burial grounds (for example papers collected in Hill \& Cumberpatch 1995; Gwilt \& Haselgrove 1997; see also Parker Pearson et al 2001, 125-6 for a summary of recent theoretical developments). The importance of structured deposition and roundhouse organization, as well as cosmology, have been proposed by many as fundamental to Iron Age life (cf Parker Pearson 1996; Fitzpatrick 1997; Oswald 1997; Parker Pearson 1999a), although more recently still doubts about the relevance of these ideas are emerging. The interpretation presented here for the organization and development of the Iron Age settlement at Dryburn Bridge has benefited from these fresh avenues of enquiry.

The Dryburn Bridge excavation took place at broadly the same time as several other important investigations of later prehistoric settlement sites in south-east and eastern Scotland, including those in East Lothian at St Germains (Alexander \& Watkins 1998) and Broxmouth (Hill 1982a), and in Angus at Douglasmuir (Kendrick 1995). Interim results of those works were published in a volume of conference proceedings edited by Harding (1982). The principal research concerns addressed in that volume relate to the comprehensive undermining of the model of Iron Age settlement development based on the Hownam Rings sequence (Piggott 1948) as universally applicable over a wide geographical area. Within this 'initial burst of 'post-Hownam' research' the Dryburn Bridge and Broxmouth excavations were considered to have proved fatal to the Hownam model (Armit 1999a, 71), and alternative methods for constructing chronologies were explored, such as through roundhouse morphologies (Hill 1982b) and artefact studies (Cool 1982). A more complex relationship between enclosed and unenclosed settlement forms was propounded. The interim report for Dryburn Bridge (Triscott 1982) is routinely referred to in what remains an area of considerable interest (Ralston 1996; Armit 1999a; Harding 2001), which has been enhanced by more recent large-scale 
excavations such as those of the Port Seton enclosures (Haselgrove \& McCullagh 2000).

With the benefit of hindsight nourished by additional site data gathered in the last 20 years, as well as theoretical and methodological developments, and not least the results of the post-excavation work, it is now possible to re-assess to what extent the Dryburn Bridge results can contribute to the post-Hownam research directions that were initially driven by Dryburn Bridge itself and Broxmouth.

\subsubsection{Radiocarbon dating}

Several radiocarbon dates were obtained from excavated samples of wood charcoal and human bone in the years around 1980, and are cited in the interim report (Triscott 1982; also Hill 1982b, 42). Those samples were dated at the University of Glasgow (refs: GU-1149, 1257, 1283-7, 1404-6, 1408-10, 1412, 1414). Calibrated age ranges are cited in this report based upon both the original lab error quoted and the adjusted errors recommended by Ashmore et al for University of Glasgow samples up to GU-1500 (Ashmore et al 2001).

The breadth of the adjusted errors associated with these determinations provides for very wide calibrated age ranges in most cases, rendering meaningful chronological interpretation impossible. To offset the problems associated with these initial dates, fresh samples were submitted for dating from human remains, animal bone, antler and wood charcoal, in many cases replicating materials previously dated.

The new samples were submitted to the Scottish Universities Environmental Research Centre (SUERC), who forwarded prepared samples for measurement at the University of Arizona AMS Facility. The results obtained from wood charcoal are cited in this report (AA-53703-5). However, the results returned for several of the dated human bone samples were surprising and outwith the expected age ranges, being significantly younger than had been anticipated and in some cases at considerable variance with samples of the same entities dated around 1980, raising significant problems for site phasing and interpretation. Subsequent investigation revealed that some of the samples had contained insufficient collagen for reliable measurement, and this probably accounted for the unexpected results (G Cook, pers comm).

In light of this, further samples of human and faunal material, including both previously dated and new sample material, were dated by the Scottish Universities Environmental Research Centre (SUERC). This final dating work provided results for the most part within the anticipated ranges, and consistent with the results of the initial dates obtained. The most recent radiocarbon measurements are cited in this report (SUERC-4068-74, 4078-9, 4082-4, 4088, 4412, 4938-9).

The measurements obtained from human and faunal remains during the intermediate dating work are rejected as a group and are not cited in this report, even though the most recent measurements of some samples concurred with the results obtained during the intermediate dating. The results of the intermediate dating work are published in Discovery and Excavation in Scotland 2003 (DES 2003, 158-9; lab refs: AA-53706-21), but it is recommended that they are not cited.

\subsection{Structure of the report}

The results are divided into two parts. The earlier prehistoric remains are presented and discussed first. While the presence of at least some of these remains may have been recognized and respected by the occupants of the Iron Age settlement, these features are chronologically distinct from it, as well as from each other in certain cases.

In describing the settlement site, a building block approach was considered to be the best method of underpinning the final interpretation of settlement development offered. For plough-truncated cropmark sites such as Dryburn Bridge, the opportunities for identifying meaningful stratigraphic relationships and datable deposits are limited, and those discovered are nearly always less than wished for. Such phased sequences as may be constructed are often not unassailable, but reflect the best judgement of the author/s (as is evident from this account, which refines the broad phasing sequence proposed in the interim account (Triscott 1982) in certain ways). It was felt that simply to describe this site based upon interpreted phases (cf St Germains, Alexander \& Watkins 1998) or by area (for example Port Seton East, Haselgrove \& McCullagh 2000) would obscure the sometimes subtle evidence that underpins the phasing model and render the account less comprehensible to future researchers seeking to deconstruct this model and propose an alternative.

Description of the physical remains of the Iron Age settlement is thus ordered by categories of features present - enclosing works; roundhouses (grouped by ground-plan morphologies); rectilinear structures pit graves; fence-lines and other boundaries; miscellaneous features - in each case highlighting the stratigraphic and spatial relationships between these and other features used to contribute to the overall sequence. Following the presentation of the results of the artefact studies and radiocarbon dating, the combined evidence is marshalled to put forward a relative and absolute chronology for the settlement.

Use of the term 'House' has been retained from the published interim report (Triscott 1982) to describe the timber-built roundhouses excavated, although it should be noted that the use of this terminology is not intended to imply a function for the structures as domestic dwellings. 'Iron Age' is also used as a convenient shorthand to describe the broad date of the settlement, although the date of settlement foundation could stretch back into a period conventionally termed 'Late Bronze Age'. 


\section{Early Prehistoric Activity: Excavation Results}

\subsection{Mesolithic artefacts and features}

A collection of chronologically diagnostic chipped stone artefacts indicates Mesolithic activity on the site. These items include 15 microliths, including a microburin, and probably also a number of blades (see Section 4.1). The microliths mostly occurred as residual items in three features associated with the Iron Age settlement: a porch post-hole of House 1; a pit cutting the outer enclosure boundary (M69); and a large pit in the southern sector of the outer enclosure (O48). Other items were recovered from the postabandonment infill of House 2. A feature that could not be identified from the site records contained 55 chipped stone pieces including four microliths, and this concentration may indicate the presence of unrecognized Mesolithic features on the site.

\subsection{Neolithic and Bronze Age artefacts and features}

Three pits (EDP, EDQ, MAA) located at the west side of the excavation area, outside the Iron Age outer enclosure, produced sherds of pottery, some of which were decorated and comparable to Late Neolithic Impressed Ware (Cool \& Cowie; Section 4.2). While these pits lay in the same part of the site, only pits EDP and EDQ can now be located precisely (illus $3)$. This may indicate that the relatively discrete, $c$ $8 \mathrm{~m}$ wide, sub-circular scatter of pits located to the west of House 3 represents an area of Late Neolithic activity, possibly even a structure of some sort, albeit flimsy by comparison to the Iron Age roundhouses in the vicinity. Certainly, none of those features produced diagnostically later prehistoric artefacts.

Moreover, there is a possibility that House 4, which previously has been assumed to be an Iron Age construction (eg Triscott 1982) may be of early date. The structural characteristics of this presumed building, in as far as they can be reconstructed, are again less regular and substantial than those of the other Iron Age buildings, and do not conform to a morphologically recognizable Iron Age type. However, as there is no clear stratigraphic or dating evidence to support the reattribution of this structure to a Late Neolithic horizon, the description of this feature is contained within the Iron Age settlement section, in which context its presence had originally been understood by the excavators (Section 7.2.3). Given the problems in relating House 4 to the overall sequence of Iron Age settlement development, combined with the aforementioned problems of structural reconstruction, there is certainly a temptation definitely to remove it from an Iron Age context altogether; however, this would be unnecessarily to transpose speculation into interpretation.

Elsewhere, a small number of bifacially retouched artefacts have been interpreted by Finlayson (Section 4.1) as related to Late Neolithic/Early Bronze Age activity. These derived from two pits within the southern interior of the outer enclosure, as well as from the topsoil. Of these, Pit O104 (illus 3), a large elongate excavation $3.5 \mathrm{~m}$ long, $1.2 \mathrm{~m}$ wide and 0.35 $0.5 \mathrm{~m}$ deep, contained several other chipped stone pieces. In the absence of any Iron Age material from its fills, this pit could represent a Late Neolithic or Early Bronze Age feature. However, it occurs in an area of the site that contained several other large pits, one (O48) notably of similar size that contained both chipped stone and diagnostically later prehistoric artefacts.

\subsection{Cist burials}

Two exceptionally deep Late Neolithic/Early Bronze Age burial cists were identified $c 10 \mathrm{~m}$ apart, and represent further evidence of pre-Iron Age activity. Although both cists lay within the circuit of the Iron Age outer enclosure boundary (illus 3), they had not been disturbed by subsequent activity on site, perhaps suggesting that their presence was recognized and respected during the occupation of the Iron Age settlement.

\subsubsection{Cist 1 (Burials 4 and 5) (illus 4; illus 5; illus 6)}

This feature was initially assumed to represent a small stone-filled pit, and it was not until the capstones had been encountered that the larger pit containing the cist was recognized. This discrepancy was caused by the nature of the backfill of the construction pit surrounding the stones, which was almost indistinguishable from the surrounding gravel subsoil. The smaller feature which was initially sectioned was interpreted by the excavators as a possible post-setting, or marker, over the cist (illus 4). The capstones were encountered $c 0.4 \mathrm{~m}$ below the present day surface of the subsoil. Although the capstones were found to have collapsed, the excavators believed that this disturbance had occurred during site clearance rather than in antiquity.

Two capstones covered the major part of the cist, with the gaps between them spanned by smaller fragments of stone (illus 5). The excavators recorded these fragments as the shattered remnants of a 


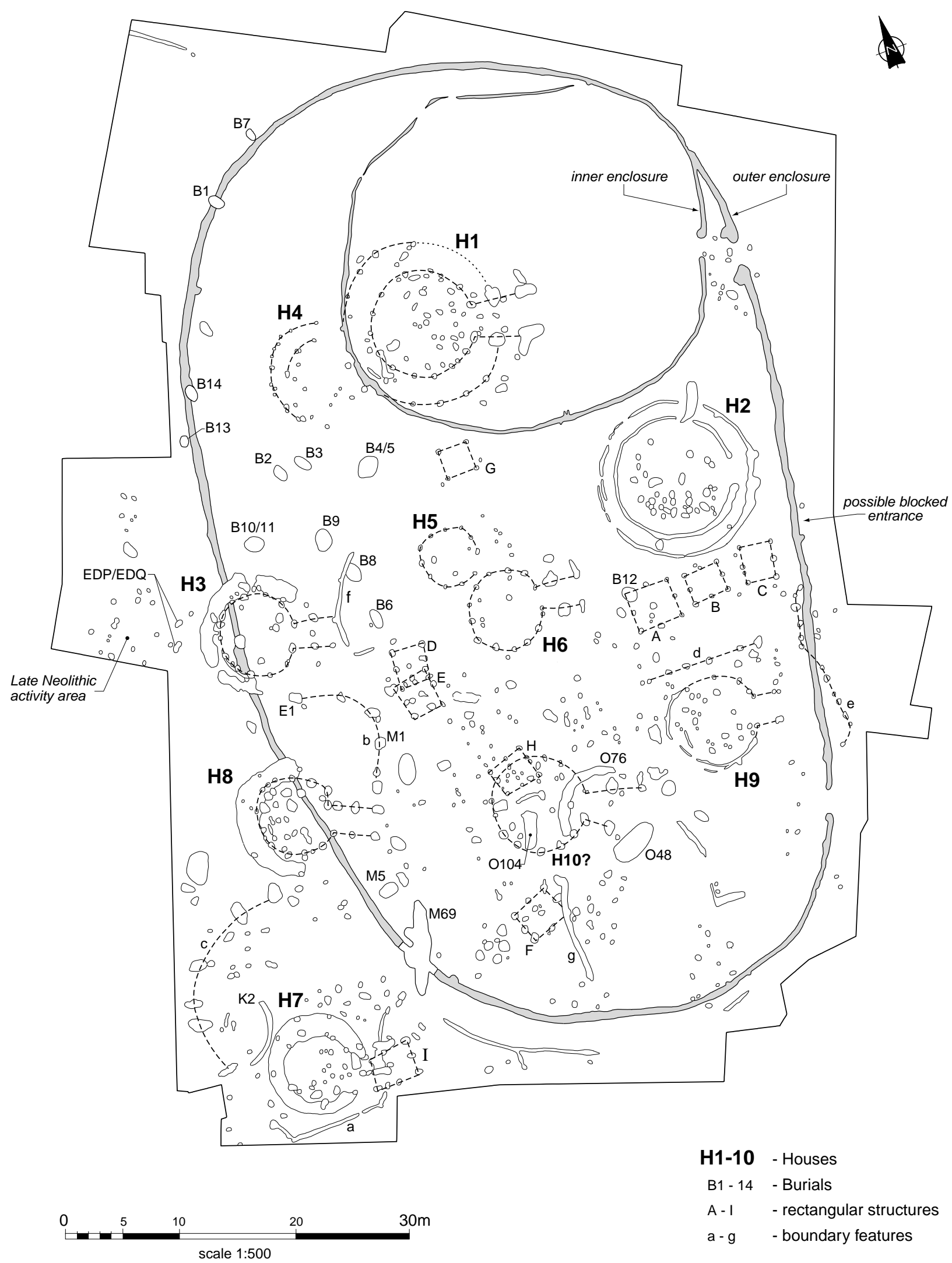

Illus 3 Site plan; with principal excavated structures and features highlighted

larger stone, which originally may have been a third covering slab. Further fragments of this broken slab were encountered in the backfill of the pit above the capstones.
The cist walls were largely formed by four upright slabs standing $c 0.6 \mathrm{~m}$ high and $c 0.1 \mathrm{~m}$ thick. A smaller stone, $0.2 \mathrm{~m}$ long, filled a gap between the north-west and north-east side slabs, at the north 


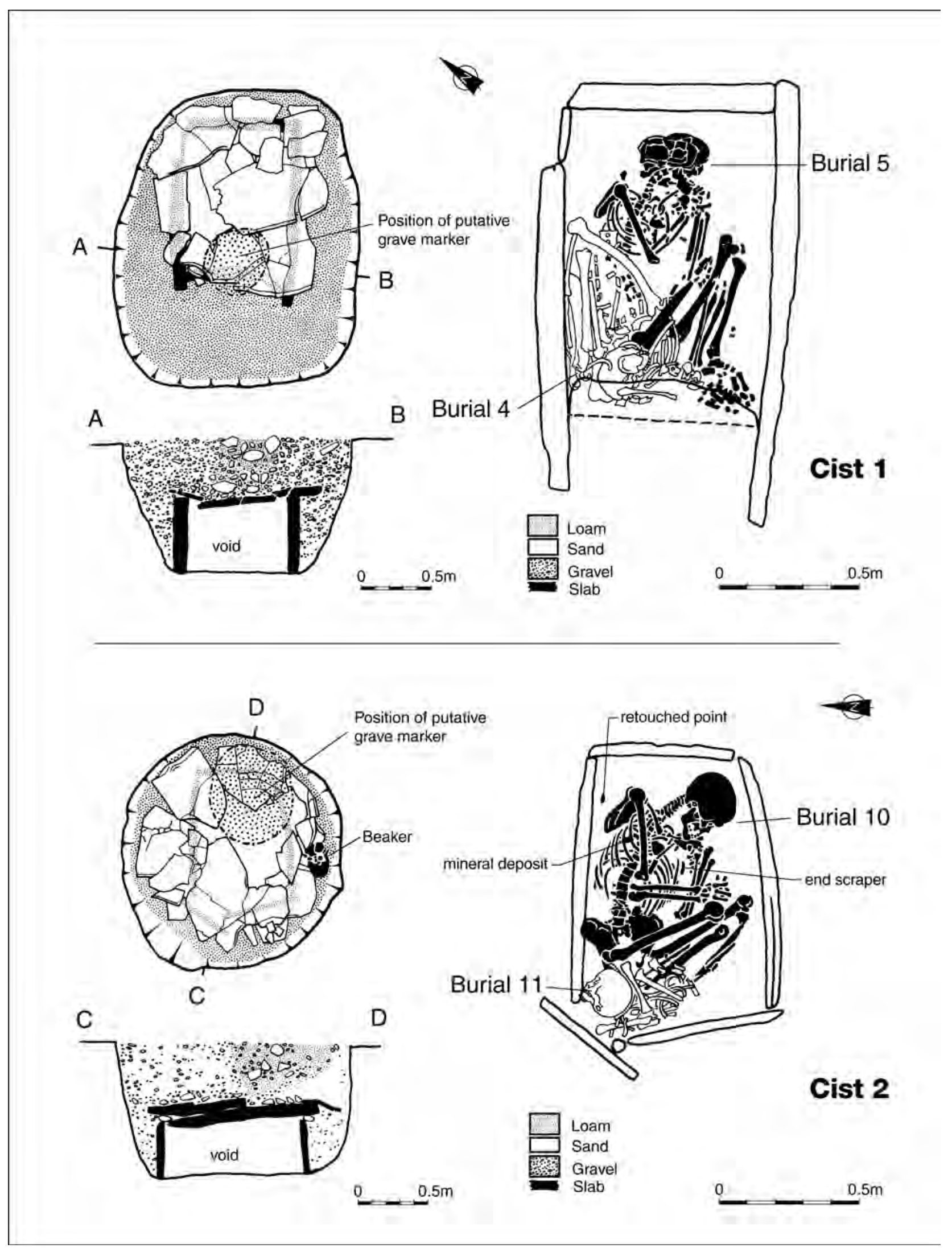

Illus 4 Cists 1 and 2; plans and sections

corner of the cist. Moreover, the south-west wall slab appeared slighter than the other main upright slabs, and it did not lie flush with the south-west ends of the north-west and south-east walls, almost as if the south-west stone were a secondary insertion shortening the cist. These surviving wall slabs defined 


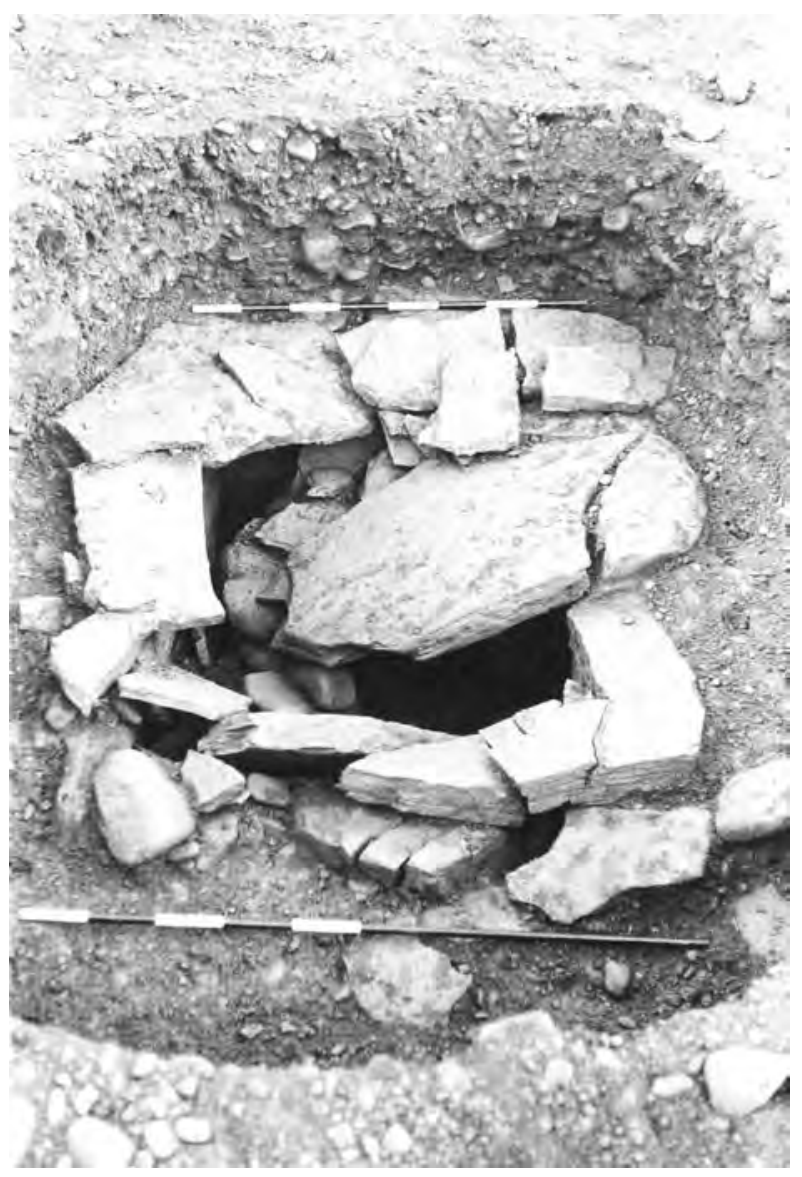

Illus 5 Cist 1; showing disturbed capstones; from south-west

a rectangular area measuring $c 1.1 \mathrm{~m}$ north-east/ south-west by $0.75 \mathrm{~m}$ north-west/south-east. All the slabs used in the construction were of calcareous sandstone, possibly derived from outcrops on the shore about $1 \mathrm{~km}$ to the east.

The skeletal remains within the cist were covered only by a thin layer of sand and gravel that had fallen in as a result of the modern disturbance, and the rest of the cist remained void. There was no laid floor to the cist. Two burials were present - a wellpreserved, crouched inhumation (Burial 5) with the remains of a disarticulated and incomplete skeleton (Burial 4) lying over the pelvis and abdomen of the former (illus 6). Burial 5 lay on its left side, with the head placed to the north-east and facing south-east. Both hands had been drawn up to the mouth and the legs were drawn up towards the chest, but the position was not tightly contracted. The skull had been smashed by the collapse of one of the capstones and the lower vertebrae and the pelvic area had been almost completely destroyed by post-mortem decay. Burial 4 comprised an apparently disordered collection of most of the large bones of one individual. The near absence of small bones is of interest as, because the preservation of bone was good, this appears not to be simply a result of post-depositional bias but the result of selective introduction of skeletal material into the cist. The skeletal remains of Burial 4 overlay

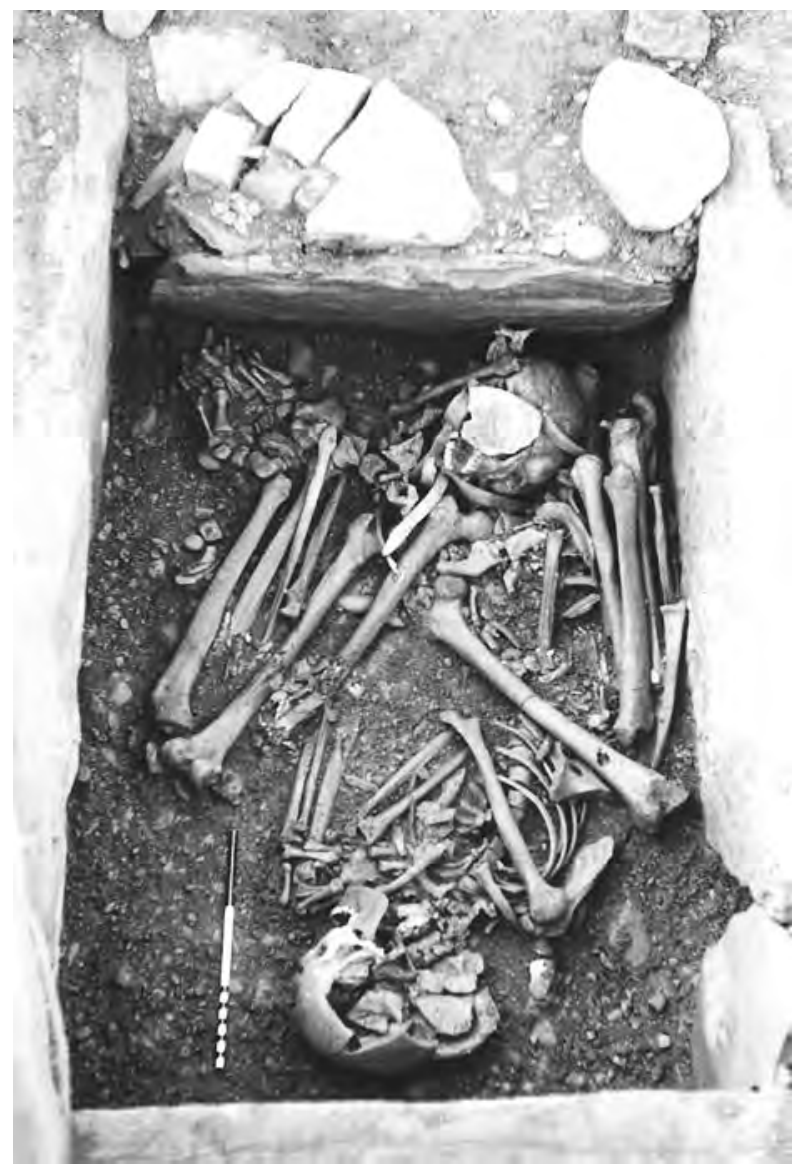

Illus 6 Cist 1; showing Burials 4 and 5; from north-east

that part of Burial 5 which demonstrated poor bone preservation, a situation presumed to relate in some way to taphonomic factors. Both individuals were mature adult males (Section 4.4.3).

The construction pit, when fully excavated, measured approximately $2 \mathrm{~m}$ north-east/southwest by $1.7 \mathrm{~m}$ with a sub-rectangular surface plan, steeply sloping sides and a slightly rounded base, the deepest point of which was about $1 \mathrm{~m}$ below the surface of the subsoil. The side slabs of the cist rested directly on the base of the pit, although noticeably off-centre to the north-east. The sand and gravel fill above and around the cist was uniform, and no doubt derived from the material quarried when the pit was excavated.

No artefacts were recovered from the cist or grave pit, but the radiocarbon dates from Burials 4 and 5 (Section 5) preclude this being an Iron Age deposit.

\subsubsection{Cist 2 (Burials 10 and 11) (illus 4; illus 7; illus 8)}

As with Cist 1 the true dimensions of the construction pit were not immediately recognized and, again, it was not until the capstones had been encountered that the nature of what was being excavated became clear. Similarly the excavators interpreted the small 


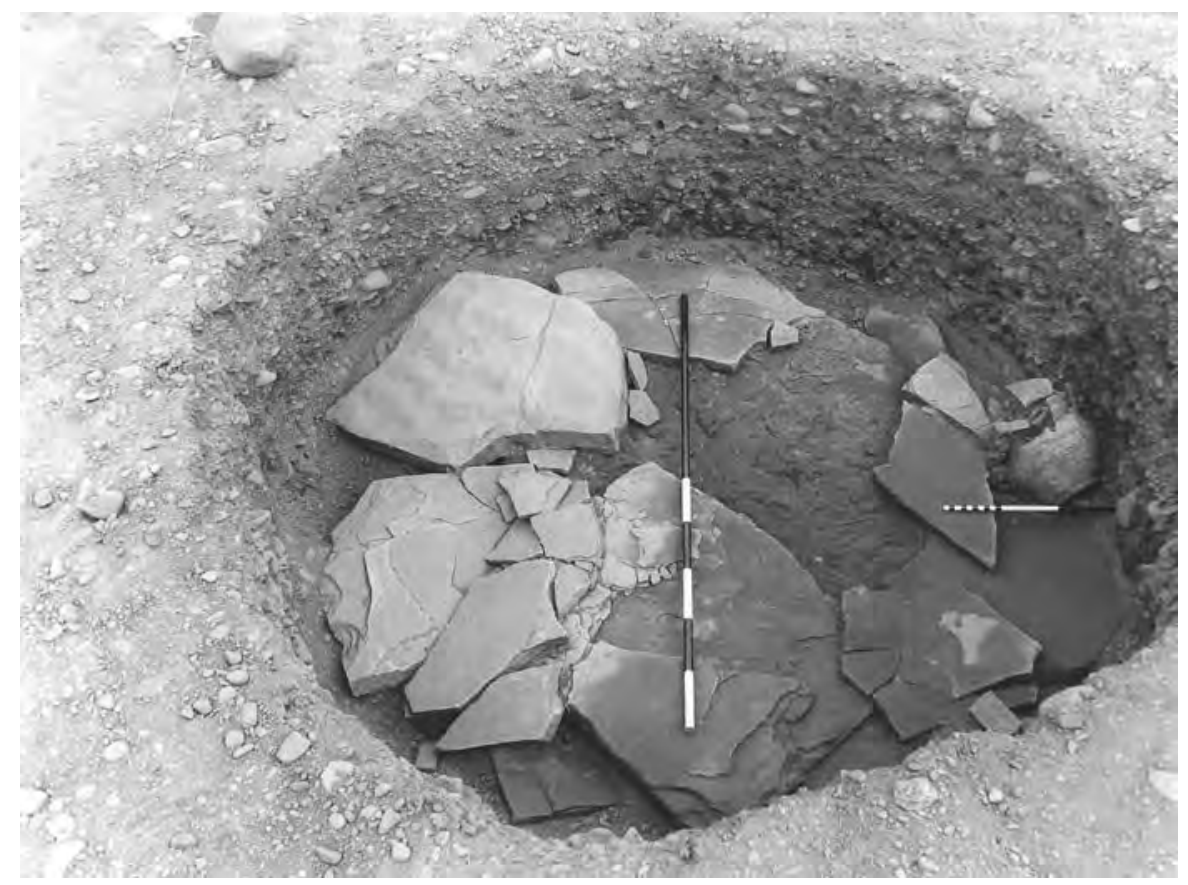

Illus 7 Cist 2; showing capstone overlain by flat slabs; and Beaker vessel; from west

pit initially investigated on the surface of the construction pit backfill as a marker (discussed further in Section 6.3).

The characters of the construction pit and cist were similar to those recorded for Cist 1 . The grave pit was sub-circular in surface plan, with near-vertical sides and a level base (illus 4). It measured $c 1.6 \mathrm{~m}$ across at the subsoil surface level, and reached a depth of $c 0.95 \mathrm{~m}$ below that level. The upright wall slabs of the cist were again placed directly on the base of the construction pit, but were of smaller dimensions than those of Cist 1 , being only $c 0.04-0.06 \mathrm{~m}$ thick and standing $c 0.4 \mathrm{~m}$ high. The wall slabs defined a sub-rectangular area measuring $0.95 \mathrm{~m}$ east/west by $0.65 \mathrm{~m}$ north/south. Four large slabs defined the sides of the cist although, as a result of either poor or deliberate design, a fifth upright had been placed obliquely across the north-west corner to plug a sizeable gap left between the north and west uprights. The remainder of the base of the construction pit, outside the cist walls, was filled with gravel barely distinguishable from the natural subsoil cut through by the pit.

The cist was not provided with a laid floor. As in this case the capping material had not collapsed, the cist remained almost completely void apart from a small amount of material that had filtered down from above. The cist was covered for the most part by a roughly triangular slab, the gaps left at the corners being closed by smaller slabs. The area between the tops of the cist walls and the edge of the pit at that level was defined by a layer of flat slabs, most of which had fragmented after deposition (illus 7).

At the southern edge of the pit, and immediately overlying the peripheral slabs, was a Beaker pot laid on its side (illus 7). The weight of backfill above this vessel had flattened and distorted it somewhat but it remained surprisingly intact with only a small portion of the rim being detached. There were no deposits within the Beaker other than clean gravel derived from the backfill. Pollen analysis of a scraping from the base of the vessel produced only one grain of Compositae pollen (Sjoerd Bohncke, pers comm to $\mathrm{J}$ Triscott).

The capstone, peripheral slabs and Beaker lay $c 0.4 \mathrm{~m}$ below the subsoil surface, and were sealed beneath a deposit of sand and gravel, which appears to represent the deliberate backfilling of the construction pit using subsoil. The postulated grave marker had been subsequently inserted into the upper part of this backfill. This upper backfill was indistinguishable from the material surrounding the cist walls at the base of the pit, reflecting primarily that unmodified subsoil had been used in both cases. There was no surviving trace of a burial, either inhumed or cremated, in the upper part of the grave pit, either associated with the Beaker or in the backfill material above this.

Within the cist itself the remains of two individuals were present (illus 8), one articulated and crouched (Burial 10) and the other disarticulated and incomplete (Burial 11). Burial 10 comprised an adult male, while Burial 11 was the remains of a 6 - to 8-yearold child (Section 4.4.3). Bone preservation was more complete than in Cist 1, however a small hole in the skull of Burial 10 had been caused by water seepage: once exposed during the archaeological excavation this hole became considerably larger. The lower leg bones of Burial 10 were less well-preserved, where they had been overlain by Burial 11 . 


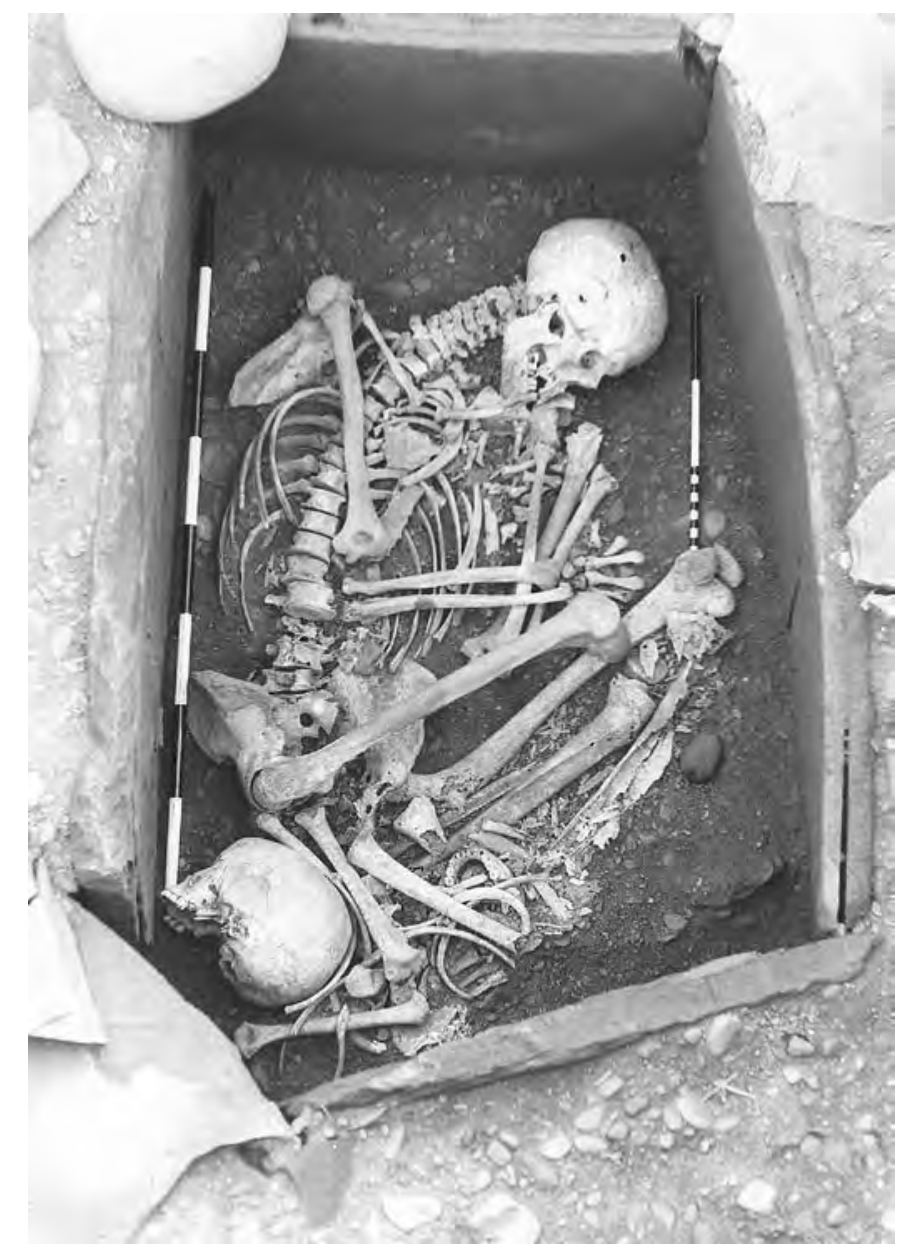

Illus 8 Cist 2; showing Burials 10 and 11; from west

Burial 10 lay on its left side, with its head to the east and facing south. The right arm lay across the body, flexed at the elbow, so that the hand rested between the knees. The left arm was tightly flexed at the elbow with its hand drawn up to the mouth. As with Burial 5 the body was not tightly contracted. The disarticulated remains of Burial 11 lay partly over the feet and lower legs of Burial 10, and partly in the gap between its pelvis and the walls of the cist. As with Burial 4, the bones present were mainly the larger ones, such as long bones, skull and pelvis; smaller bones were under-represented. The irregular and slightly bulging north-west corner of the cist, described above, may have been deliberately constructed in anticipation of the deposition of the second inhumation in this area.
Cleaning around the skeletal remains of Burial 10 revealed a bilaterally retouched point made on a blade lying by the right shoulder while an end scraper lay amongst the ribs, apparently having fallen through the chest during decay (illus 4). In addition, on the uppermost two right ribs, a greenish white deposit was present, seemingly containing some fibrous material. This deposit deteriorated rapidly on exposure, and although it was removed as a unit with the ribs it did not survive intact. It seems likely that this was a mineral deposit altered by water dripping from the capstone. If this were the case, then it is possible that it could have formed around some copper alloy object already in that position, such as a pin or an awl. 


\section{Early Prehistoric Activity: The Finds}

\subsection{Chipped stone by Bill Finlayson}

An assemblage of 312 pieces of chipped stone was recovered during the excavation. These items were mostly recovered from Iron Age settlement features (see Section 3.1), although it has not been possible to identify the contexts of recovery in all cases. The assemblage was analysed using a modification of a system developed previously (Wickham-Jones 1990), refined in a number of studies by the author. Most of the diagnostic material appears to reflect Mesolithic activity, with some Late Neolithic/Early Bronze Age forms also present. However, the assemblage shows evidence for a wide range of techniques, suggesting that knapping from many periods may be represented. This allows for the possibility that at least some of the material is directly related to the Iron Age settlement (see Young \& Humphrey 1999 for a recent review of the use of chipped stone tools in the Iron Age).

The raw materials employed comprise flint (159 pieces), chert (134 pieces), chalcedony (14 pieces), jasper (two pieces), agate (one piece), quartz (one piece) and a single piece of an unidentified material. This range is typical of assemblages from the eastern Borders (cf Mulholland 1970). Few pieces of less than $10 \mathrm{~mm}$ were recovered. This apparent bias may be the result of recovery methods.

Primary reduction techniques include blade production from prepared blade cores and flake production from a variety of core types, including prepared platform cores, amorphous flake cores and bipolar cores. All stages of primary knapping are present, ranging from a pebble to core rejuvenation products, indicating that this activity occurred in the vicinity. The assemblage composition (Table 1) shows that although the material is dominated by flakes, a fairly high proportion (12.5\%) of blades (defined as regular flakes, more than twice as long as wide, made by blade technique) are present. This ratio of blades to flakes is indicative of Mesolithic industries. The chunks (broken blocks, not formed by conchoidal fracture) are mostly chert, and simply reflect the tendency of the Southern Uplands chert to splinter along bedding planes.

An extremely mixed collection of retouched tools is present. As with primary technology, these were produced by a number of techniques. These range from the manufacture of microliths, involving microburin production, to bifacially invasive pressure flaked tools more typical of the Bronze Age. Fifteen of the retouched tools are microlithic. Possible resharpening flakes are also present. A full catalogue of chipped stone pieces, including detailed descriptions of the retouched items, forms part of the site archive.
Table 1 Composition of the chipped stone assemblage

\begin{tabular}{lr}
\hline Blades & 40 \\
Flakes, inner irregular & 102 \\
Flakes, inner regular & 58 \\
Flakes, secondary & 74 \\
Chunks & 19 \\
Cores & 15 \\
Bipolar pieces & 3 \\
Pebbles & 1 \\
\hline
\end{tabular}

It appears clear from the lithic material that the site of Dryburn Bridge occupies an area used as a Mesolithic camp. The microliths form $4.8 \%$ of the entire assemblage, which is an unusually high proportion, even for an entirely Mesolithic assemblage. It can be assumed that the large number of blades also mostly derive from this Mesolithic occupation.

Two well-made retouched flint artefacts were associated with Burial 10 in Cist 2. They are a bilaterally retouched point made on a blade and an end scraper. Both artefacts are made on a similar good quality grey flint and the point, at $66 \mathrm{~mm}$ long, is the largest retouched artefact in the assemblage.

Most of the other retouched artefacts are not chronologically diagnostic, although one, from the topsoil, with bifacial invasive retouch covering both faces, is probably Late Neolithic or Bronze Age. A small number of other bifacially retouched tools and fragments probably date to this phase. There is no worked material that could be confidently proposed as being of Iron Age origin.

The usage of raw materials suggests a move towards an increased use of flint in the post-Mesolithic phases. All the bifacially retouched tools are of flint, whereas seven of 15 microliths are made of chert. While this may simply reflect the technological requirements of bifacial working, it may also reflect access to more distant sources of different raw material, possibly through exchange.

\subsection{Late Neolithic pottery (illus 9) by Hilary Cool \& Trevor Cowie}

Three pits produced sherds of decorated pottery comparable to Late Neolithic Impressed Ware (Cat nos $45,46,49,50$ and 54). Plain sherds from the same pits (Cat nos 47, 48, 51, 52, 53 and 55) are presumably from contemporary vessels. These decorated sherds display twisted cord and bird-bone impres- 


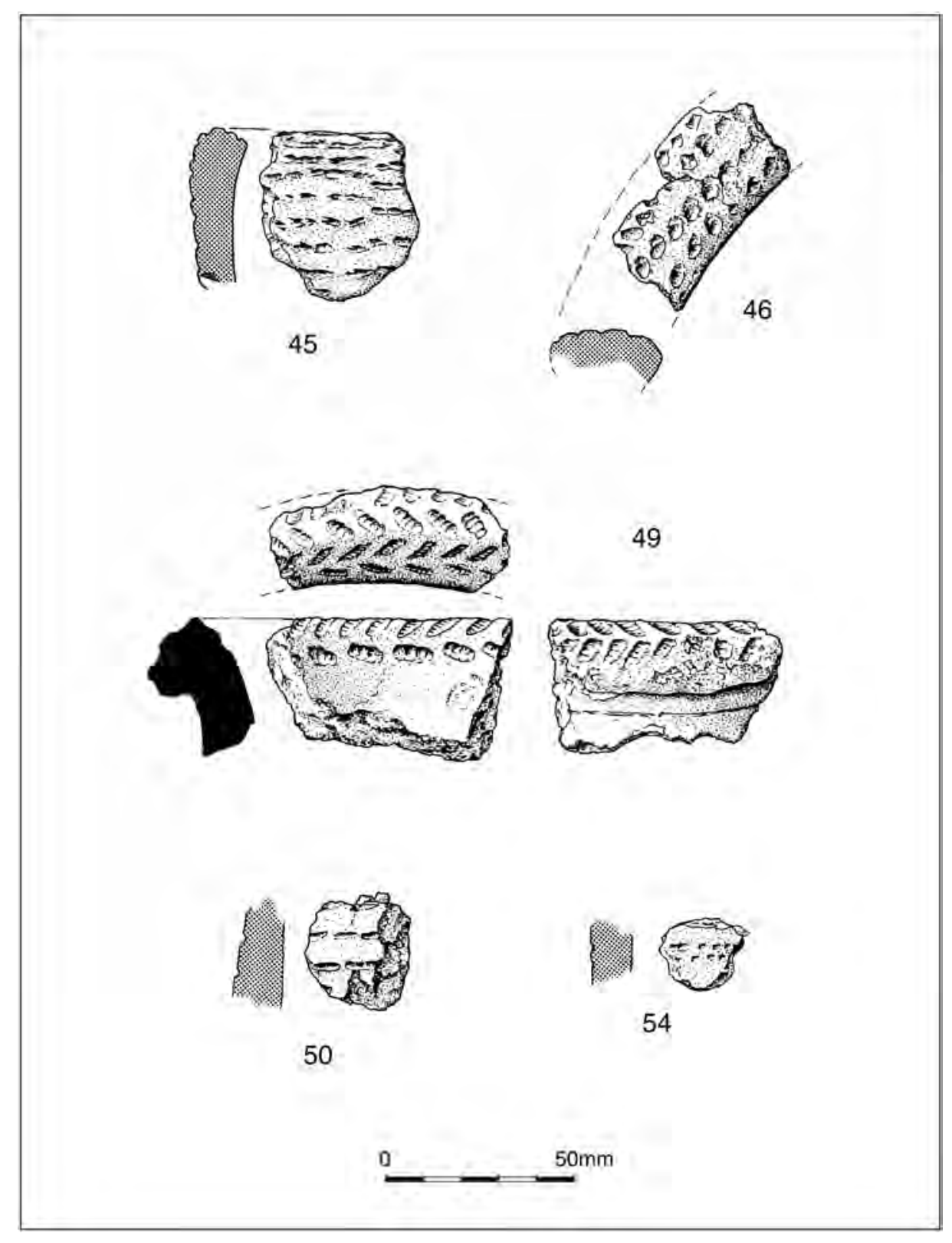

Illus 9 Late Neolithic Impressed Ware

sions and stab-marks characteristic of Impressed Ware (McInnes 1969). At the time of analysis (1982) this material could not be divided into various styles, as can the equivalent Peterborough wares of southern Britain. However, there have for some time been indications that eventually regional styles within the northern material may be isolated (Longworth 1967, 72; Burgess 1976, 173; cf Cowie $1993 b, 125-6)$. These wares vary in the combination of decoration and form from site to site and too few sherds were recovered from Dryburn Bridge for an analysis to find the most commonly used decorative techniques, the most similar assemblage and so on to be meaningful. All that can be usefully achieved is to point out general parallels.

There are, for example, obvious similarities to the assemblage from Hedderwick, East Lothian
(Callander 1929, 67-72) where twisted cord impressions in lines, 'maggots' and bird-bone impressions occur. Cat no 46 may come from a bowl similar to several that were found at Brackmont Mill, Fife (Longworth 1967, fig 5.14 and 15). Cat no 49 has similarities to a vessel from Meldon Bridge, Peeblesshire (Burgess 1976, fig 9.7, top; see also Johnson 1999) which shares the narrow neck and herringbone pattern of impressed cord around the rim. Cat no 51 should be noted as it is an unusual fragment and may be from a lug.

\section{Catalogue of illustrated sherds}

451 flat-topped rim sherd tempered with angular white and grey grits (up to $8 \mathrm{~mm}$ in length). Fabric fired buff/ 


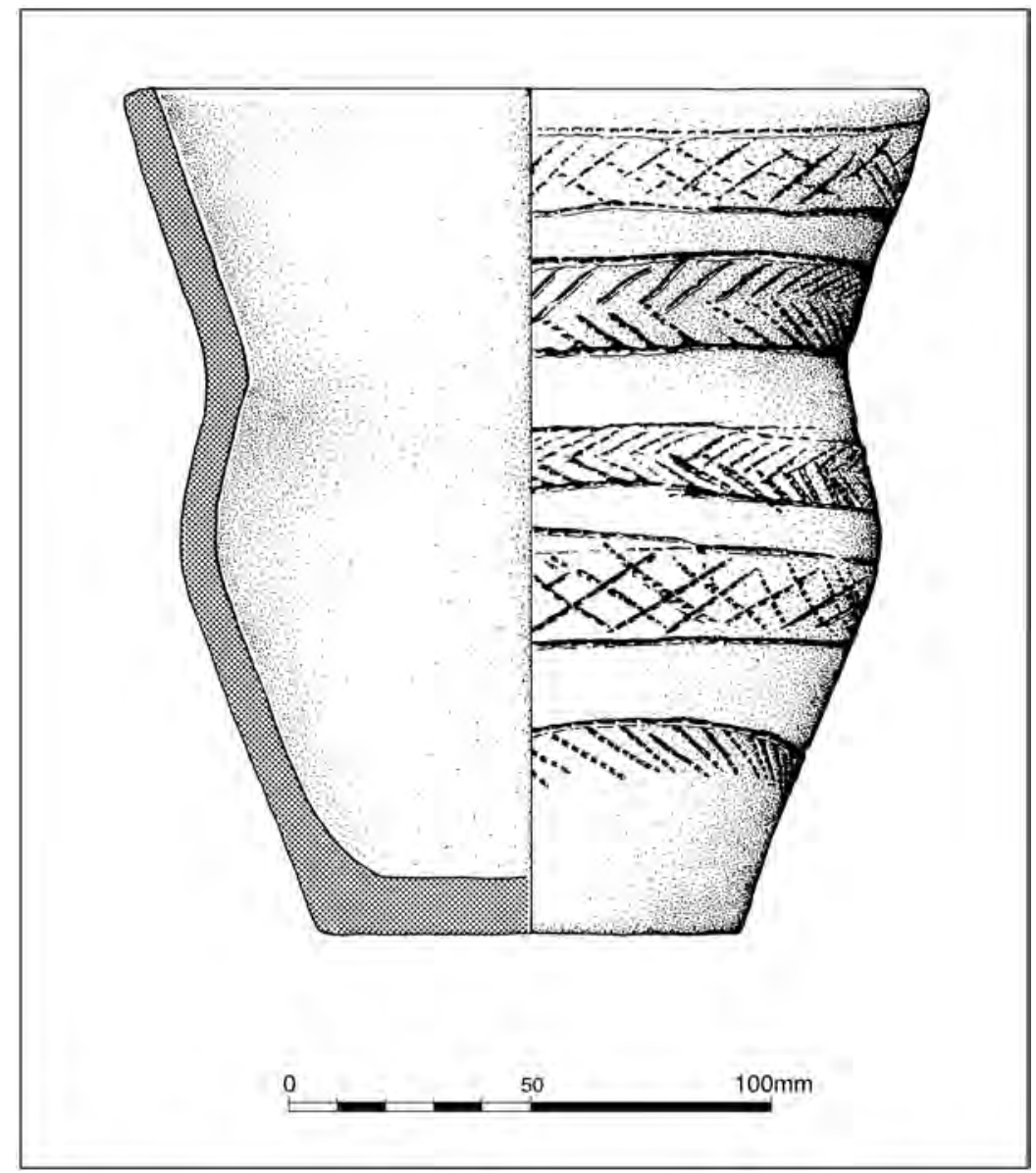

Illus 10 Beaker from above Cist 2

brown on rim top and interior surface, dark grey in core and on exterior surface. Top of rim decorated by three diagonal twisted cord impressions; exterior decorated by seven rows of elongate stab marks. Context: Pit EDP.

463 rim sherds with outer surface only (1 illustrated). Rim has internal bevel and shape of wall suggests sherd came from a bowl. Tempered with angular grey grits (up to $10 \mathrm{~mm}$ in length). Fabric fired buff/red/orange. Exterior surface decorated by four rows of deep kidney-shaped, probably bird-bone, impressions. Context: Pit EDP.

491 rim sherd, rim out-turned with straight diagonal bevel and straight neck, clay beneath out-turn messily smoothed. Tempered with grey and black and white crystalline grits (up to $4 \mathrm{~mm}$ in length). Fabric fired dark grey in core and interior, brown/pink on exterior surface. Rim decorated by five rows of diagonal twisted-cord 'maggots' arranged in a herring bone pattern - one row on inside of rim, two rows on bevel and two rows on curve of bevel. Deep groove on neck body junction. Context: Pit EDQ.

501 body sherd tempered with dark angular grits (up to $8 \mathrm{~mm}$ in length). Fabric fired dark grey with brown, cracked interior surface. Exterior decorated by two rows of elongate stab marks. Context: Pit EDQ.

541 body sherd tempered with angular grey and black and white crystalline grits (up to $6 \mathrm{~mm}$ in length). Fabric fired dark grey. Exterior decorated by two rows of small triangular impressions. Context: Pit MAA.

\subsection{Beaker vessel (illus 10; illus 11; illus 12; illus 13) by Alison Sheridan}

This vessel was found lying on its side, resting on the slabs above the cist at the southern edge of the pit for Cist 2. The weight of the pit backfill had distorted the pot so that most of the body had been flattened into an oval shape, measuring $195 \times 130 \mathrm{~mm}$ at its rim (illus $11)$; its current height of $c 185 \mathrm{~mm}$ may therefore be slightly different from its original height. Although thus warped and cracked, the pot is essentially intact, with only a few fragments missing.

The pot has a gently squared-off rim, slightly flaring neck around $60 \mathrm{~mm}$ in height, slightly bulbous upper belly, and flat base (whose interior is also flat). The pot's profile varies considerably thanks to its distortion: viewed narrow side on (as in illus 12), it appears fairly slender, whereas if viewed broad side on (as in illus 13), the belly appears plumper. The base diameter is $91-2 \mathrm{~mm}$ and the wall thickness at the neck is $c 8.5 \mathrm{~mm}$. The fabric of the pot is fairly fine, and although it contains fairly numerous angular and sub-angular grits of black and speckled white-black stone (up to $12 \times 7 \mathrm{~mm}$ in size), the surfaces had been carefully smoothed, so relatively few protrude. The exterior and interior surfaces had been slipped prior 


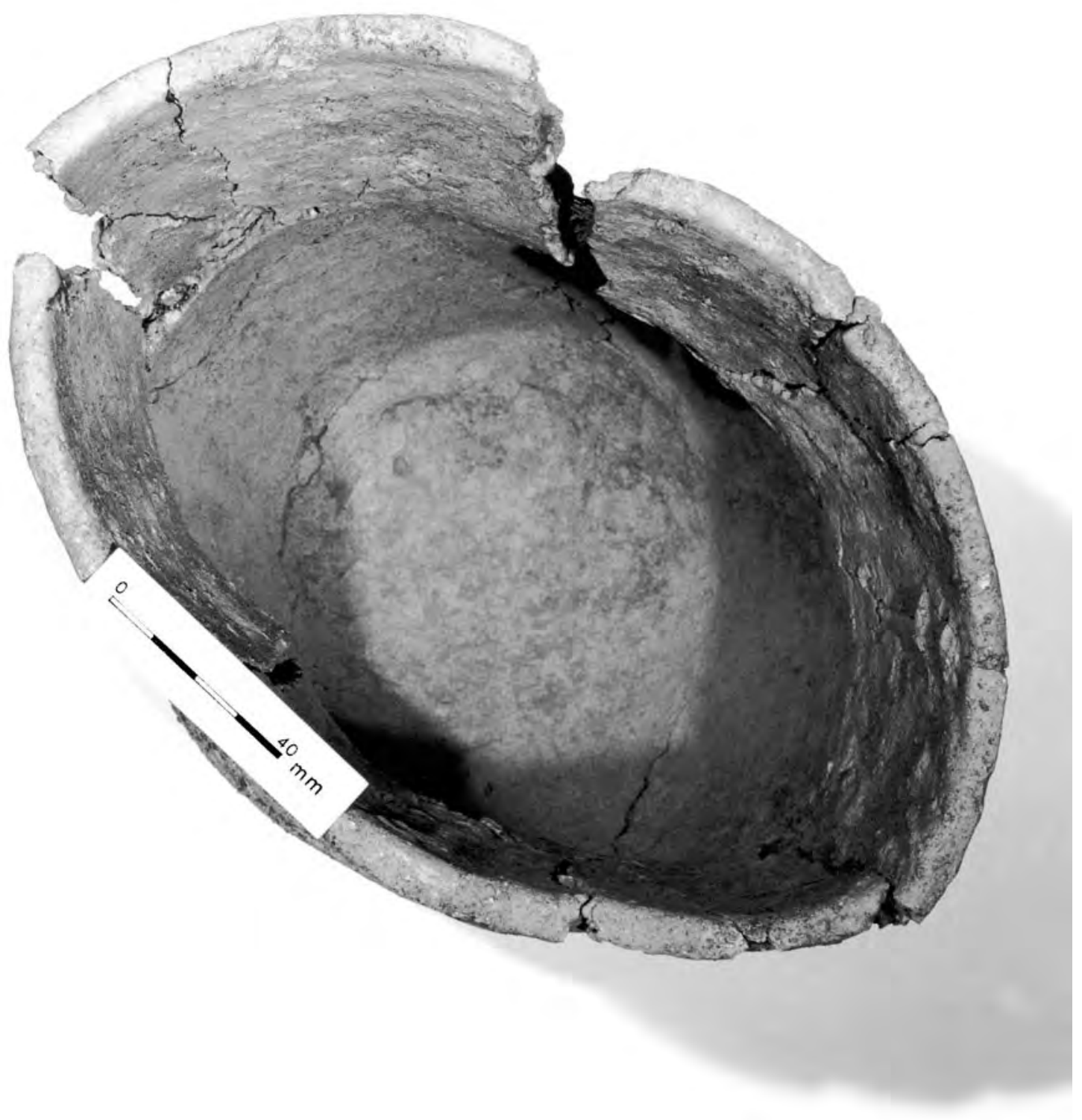

Illus 11 Reconstructed Beaker; overhead view

to the pot's decoration. Decoration consists of impressions of rectangular-toothed combs, arranged in zones. On the neck are two bands, the upper one consisting of a criss-cross design, the lower of horizontal running chevrons; each is framed top and bottom by a continuous horizontal line. This scheme is repeated in reverse on the upper belly, and below that there is a horizontal line with diagonal impressions below it. Three combs may have been used to create this decoration, with lengths of around 20,30 and $50 \mathrm{~mm}$, respectively; each comb was $1-1.5 \mathrm{~mm}$ wide.

The outside of the pot is a mottled reddish-brownbuff-mid brown colour; the reddish-brown extends through the wall and into the interior, indicating that the pot had been fired for long enough to burn out any organic material in the clay. There were no obvious traces of encrusted organic residues on the interior (cf Bohncke's negative results from pollen analysis, Section 3.3.2), although there is a small patch of very thin, blackish material on the outside of the neck.
Whether this relates to the pot's former contents (if any) is uncertain.

The Beaker finds its closest parallels in terms of shape and decorative scheme among those vessels classified by Clarke as 'Developed Northern' (N2) and 'Developed Northern (long-necked)' (N2(L); Clarke 1970) and by Lanting \& van der Waals as 'step 5' (Lanting \& van der Waals 1972), in their scheme for north-east England and south-east Scotland. The Beakers found elsewhere in East Lothian are not generally very similar to the Dryburn Bridge pot, the least dissimilar example being an N2(L) Beaker from Nunraw (Clarke 1970, fig 558), which includes zones of horizontal running chevron comb impressions.

In terms of dating, the Beaker's position with respect to the cist makes it hard to tell whether it had originally belonged with the disarticulated body (Burial 11) or with the articulated body (Burial 10). However, given that these two bodies are chronologically indistinguishable in radiocarbon terms (Section 


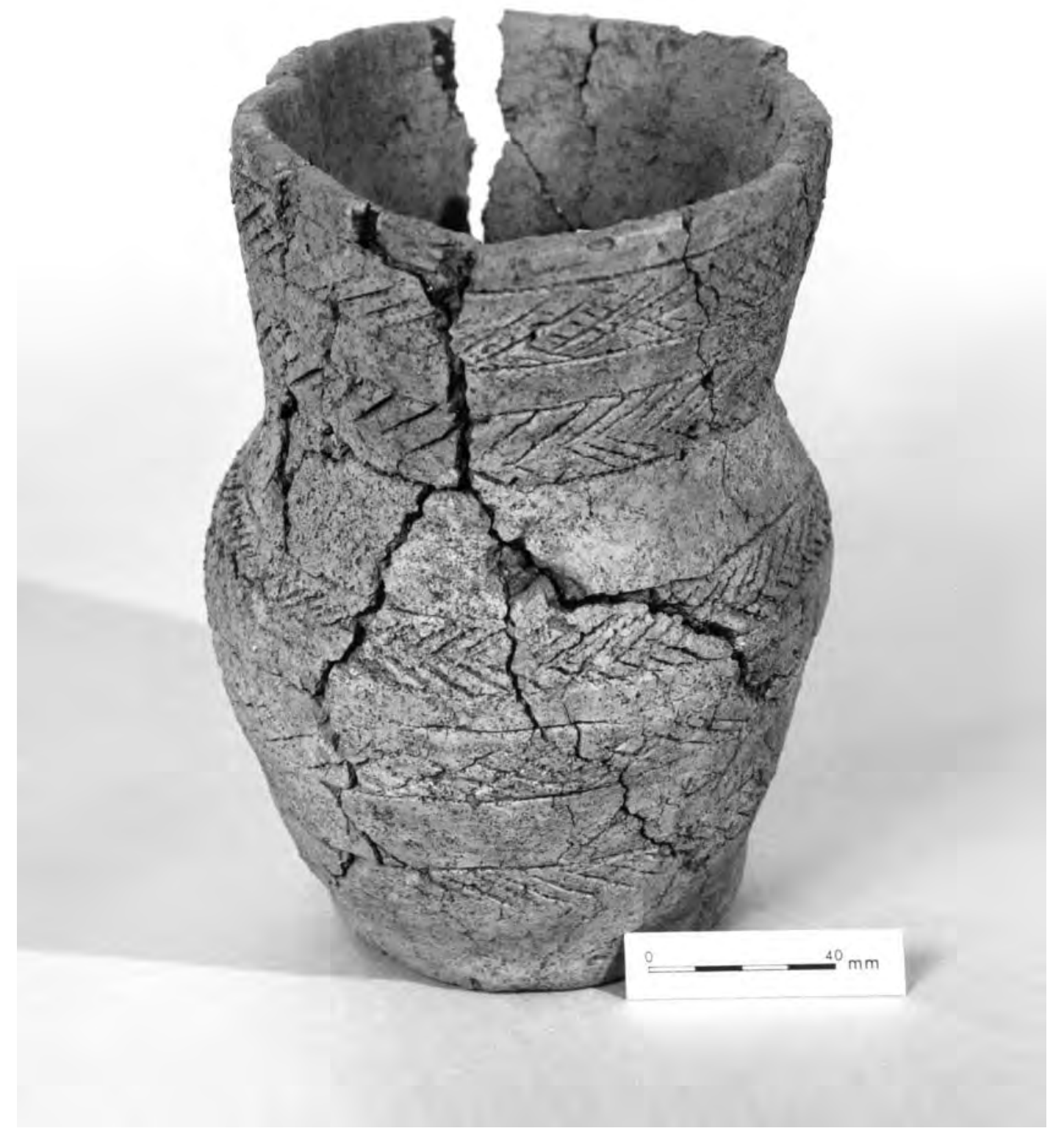

Illus 12 Reconstructed Beaker; 'narrow side' view

5), this uncertainty of association is irrelevant. When viewed within the overall range of reliable dates for Scottish Beakers (illus 14), both dates for Cist 2 fall comfortably within the overall range for Beaker currency in Scotland. This extends from 2500/2400 BC to $c 1800 \mathrm{BC}$, with most examples falling within the range 2300-1950 BC (which coincides with the overall Dryburn Bridge Cist 2 date range of 2290-1970 cal BC at 2-sigma). The other dated Beakers of Clarke's N2 and N2(L) types (from Cists 1 and 2, Broomend of Crichie and Tavelty, Aberdeenshire) are not especially similar to the Dryburn Bridge example, and of these the Broomend of Crichie Cist 2 examples are associated with a date of $3932 \pm 35$ BP (OxA-11243) that is markedly, and inexplicably, earlier than other Scottish Beaker dates.

As noted elsewhere in this report, the position of the Beaker above the cist is very unusual, and the significance of this placement is hard to ascertain. It appears to have been deposited immediately before the cist pit was backfilled, and on top of the slabs that have been interpreted as evidence for paving, a pit lining or a two-tier structure (Section 6.2). That it had probably been deposited upright, and had tipped over by the weight of the backfill, is suggested by the gravel found inside it. 


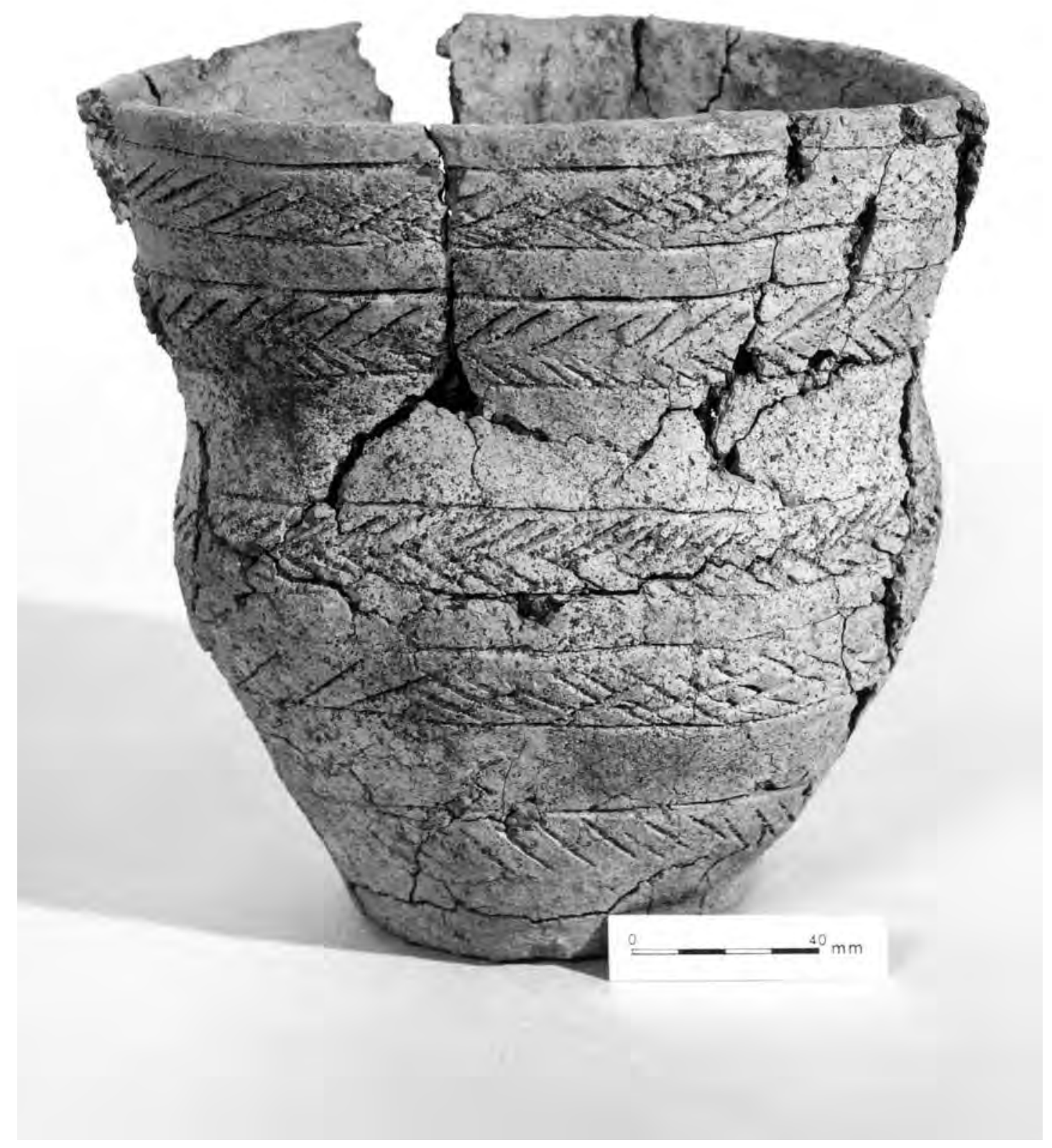

Illus 13 Reconstructed Beaker; 'broad side' view

Other examples where Beakers (or parts thereof) have been found above graves do not provide an exact parallel for the practice here. At Chapelden, Aberdeenshire, fragments of an incomplete second Beaker were placed on the capstone of a cist containing a complete Beaker (Greig et al 1989). Here the practice was interpreted in terms of an act of mourning, perhaps the smashing of a pot to make a libation over the closed cist, or depositing fragments of a pot used by the mourners to drink to the deceased. Other examples of mourning practices were cited by the authors: patches of burning on top of two Beaker cists in the cemetery at Borrowstone, Aberdeenshire, and the deliberate breakage of jet pendants at Barns Farm, Fife (Greig et al 1989, 78). On Biggar Common, a Beaker smashed into nearly 200 sherds was found at various locations in and over a grave containing a handled Beaker: on the floor of the burial pit, within the cairn covering it, and on top of the cairn (Sheridan 1997, 211, 213-5). Here, once more, the pot's deliberate breakage and deposition during the course of the burial was regarded as part of the mourning rituals. At Dryburn Bridge, however, the Beaker was deposited intact, as if it should have been inside the 


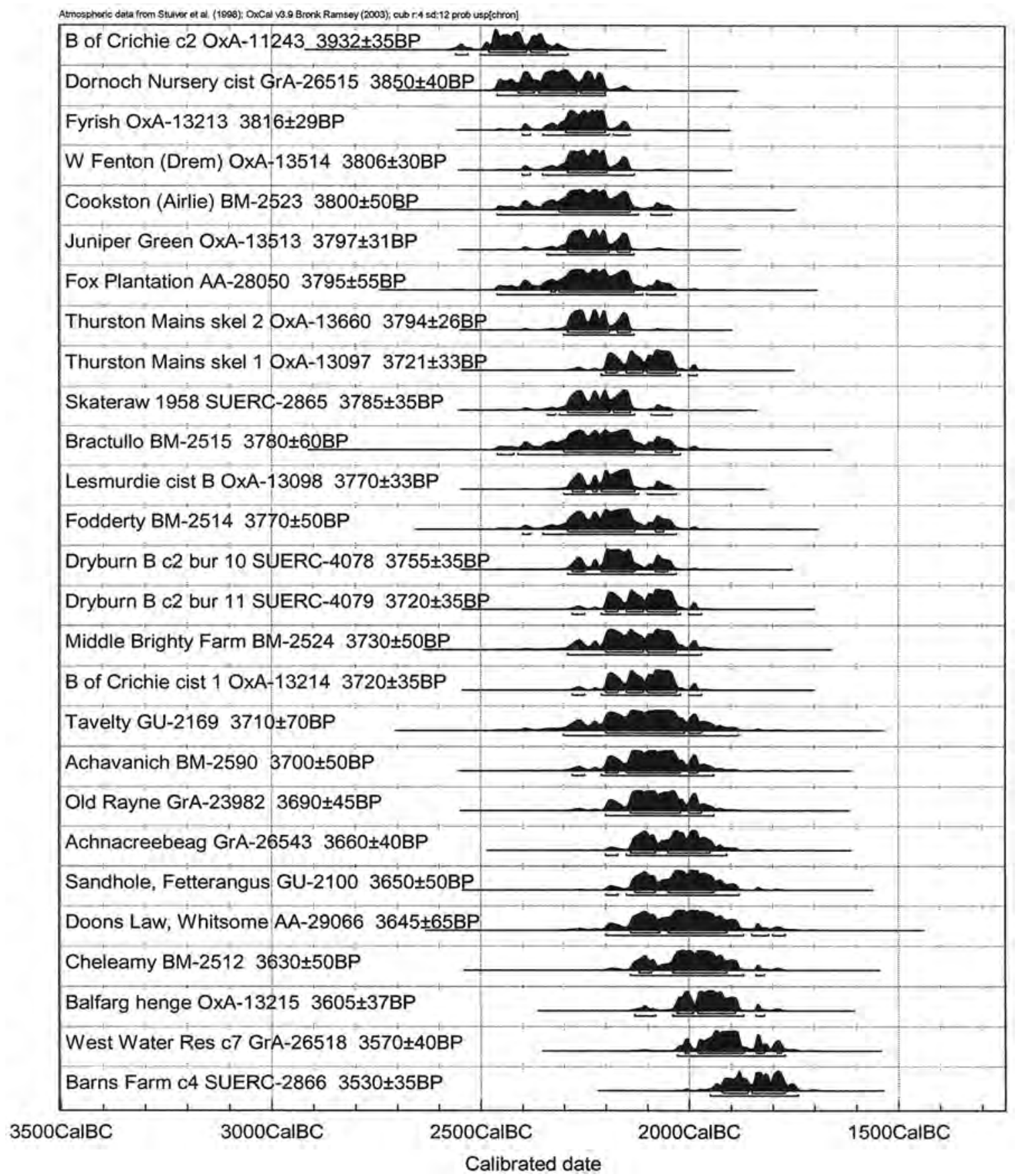

Illus 14 Radiocarbon dates for Scottish Beakers (courtesy of Alison Sheridan)

cist accompanying the deceased on their journey to the afterlife. The uncertainty over whether it had originally been intended as a grave good for Burial 10 or Burial 11 (or indeed as a votive offering for both) makes definitive interpretation impossible.

\subsection{Human remains from the cists by Julie Roberts}

\subsubsection{Introduction}

The skeletons recovered from the cists were originally analysed $c 1980$ (Harman, typescript in project archive deposited with National Monuments Record for Scotland). Burials 4, 10 and 11 were dated by radiocarbon methods in $1979 / 80$, a process that involved the destruction of substantial quantities of bone (by comparison to the much smaller sample sizes now required). This was particularly unfortunate in the case of Burial 11 where the dated elements (both tibiae) might have helped to confirm the diagnosis of leprosy (see Section 4.4.7). In resampling the remains for fresh dating (Section 5) an attempt was made to take the minimum amount of bone necessary for the dating to be successful. Methodologies used in the analysis of the skeletal remains are recorded in Appendix I. 


\subsubsection{Preservation}

In general terms the cist burials were in a far better state of preservation than the Iron Age pit burials (Section 9.2). The former had been protected from taphonomic agents, such as fluctuating water levels and mechanical disturbance (animal or human), by the stone slabs of the cist. They had not been physically disturbed by Iron Age, or later, activity until the time of the 1978 excavations. An assessment of the state of preservation of each skeleton was made, based on the percentage of the skeleton surviving, the amount of fragmentation present and the degree of surface erosion to the bones.

The two disarticulated skeletons (Burials 4 and 11) were in a fair condition (40-70\% complete) and the two articulated skeletons (Burials 5 and 10) were in a good state of preservation (over $70 \%$ complete). If it is assumed that only one burial event took place within each cist, an explanation for the differential states of preservation and articulation of the burials within the cists might relate to the condition of the bodies when they were actually placed within them. If the occupants of the cist had not died at the same time it would have been necessary to store the body of the individual who had died first, perhaps above the ground or in another temporary grave, until such a time that they could be buried with their 'partner'. Excarnation prior to burial would certainly have speeded up the decomposition process and could also have caused the skeleton to become disarticulated (cf Carr \& Knüsel 1997). The same could have resulted from temporary burial and subsequent exhumation. Either of these practices might account for the under-representation of the hand and foot bones in Burials 4 and 11.

\subsubsection{Age at death and sex}

Table 2 summarizes information on age at death and sex of the four individuals interred in the two cists. Despite using multiple methods (including dental attrition) wherever possible, in almost all cases the ages at death estimated using methods developed since the time of Harman's original report corresponded closely with those proposed initially by Harman, based on dental attrition alone.

Table 2 Summary of ages at death and sex of burials from cists

\begin{tabular}{lll}
\hline Burial no & $\begin{array}{l}\text { Age at death } \\
\text { (years) }\end{array}$ & Sex \\
\hline 4 & $35-45$ & Male \\
5 & $30-35$ & Male \\
10 & $45-60$ & Male \\
11 & $6-8$ & Unknown \\
\hline
\end{tabular}

\subsubsection{Cranial metric data}

Table 3 shows all the cranial measurements taken on each adult skeleton. Unfortunately, although most of the cranium of Burial 5 was present, it was fragmented and had been glued back together in such a way that any measurements taken would have been inaccurate.

Table 3 Cranial measurements of the adult skeletons from the cists. -, measurement not possible; /, L/R

\begin{tabular}{lccr}
\hline Measurements (mm) & \multicolumn{3}{c}{ Burial no } \\
& $\mathbf{4}$ & $\mathbf{5}$ & $\mathbf{1 0}$ \\
\hline Maximum cranial length & 195 & - & 180 \\
Maximum cranial breadth & 151 & - & 154 \\
Bi-zygomatic diameter & 145 & - & 140 \\
Basion-bregma height & 150 & - & 153 \\
Upper facial height & 70.5 & - & 68 \\
Minimum frontal breadth & 103 & - & 98 \\
Upper facial breadth & 110 & - & 106 \\
Nasal height & 53 & - & 48 \\
Nasal breadth & 26 & - & 24 \\
Orbital breadth & $42 / 44$ & - & $43 / 42$ \\
Orbital height & $31 / 30$ & - & $33 / 33$ \\
Inter-orbital breadth & 15.8 & - & 15 \\
Foramen magnum length & 39 & - & 34 \\
Foramen magnum breadth & 28.8 & 30 & 30 \\
Mastoid length & $34 / 36$ & 35 & $35 / 36$ \\
Chin height & 37 & 32 & 30 \\
Mandibular length & 105 & 98 & 91 \\
Bi-gonial breadth & - & 109 & 105 \\
Bi-condylar breadth & - & - & 129 \\
Maxillo-alveolar breadth & 62 & - & 53 \\
Maxillo-alveolar length & 52 & - & 48 \\
\hline
\end{tabular}

It was possible to calculate the cranial index, upper facial index, nasal and orbital index of Burials 4 and 10. Burial 4 had a mesocranic/medium-shaped head, while Burial 10 had a brachycranic/broadshaped head (values of 77.4 and 85.5, respectively). Both individuals had wide faces, average nasal apertures and wide orbits (values being 48.6 in both individuals for upper facial index, 49 and 50 for nasal indices and 73 and 76 for orbital indices). The metric data actually belied the appearance of Burial 10 who had distinctive facial features that gave the impression of being narrow. This was perhaps due to the fact that he had a prominent overbite and large hooked nasal bones. It was his comparatively short jaw that caused the prognathism (overbite), rather than any abnormalities of the maxilla. 


\subsubsection{Post-cranial metric data}

Table 4 Post-cranial metric data for the skeletons from the cists

\begin{tabular}{|c|c|c|c|c|}
\hline \multirow[t]{2}{*}{ Measurements } & \multicolumn{4}{|c|}{ Burial no } \\
\hline & 4 & 5 & 10 & 11 \\
\hline Clavicle length & $-1-$ & $-/ 154$ & $-1-$ & $-1-$ \\
\hline Glenoid length & $-/ 38$ & $-/ 40$ & $37 / 37$ & - \\
\hline Glenoid breadth & $-/ 30$ & $-/ 30$ & $28 / 29$ & - \\
\hline Humerus head diameter & $47 / 46$ & $-/ 46$ & $-/ 50^{*}$ & NA \\
\hline $\begin{array}{l}\text { Humerus epicondylar } \\
\text { width }\end{array}$ & $-/ 60$ & - & $-/ 64$ & NA \\
\hline Humerus length & $-/ 321$ & - & $-/ 315$ & $-/ 200$ \\
\hline Radial head diameter & $21 / 23$ & - & - & NA \\
\hline Radius length & $253 / 255$ & - & - & $-/ 146$ \\
\hline Ulna length & $-/ 280 *$ & - & - & $-/-$ \\
\hline Femoral head diameter & $-/ 47$ & $50 /-$ & & NA \\
\hline Femur A-P diameter & $-/ 28$ & $25 /-$ & $25 /-$ & NA \\
\hline Femur M-L diameter & $-/ 36$ & $35 /-$ & $37 /-$ & NA \\
\hline Platymeric index & 79 & $71 /-$ & $67 /-$ & NA \\
\hline Femur length & $-/ 446$ & $-1-$ & $446 /-$ & $-1-$ \\
\hline Femur bicondylar & $-1-$ & $-1-$ & $-1-$ & NA \\
\hline Tibia A-P diameter & $38 / 39$ & $36 / 36$ & $-1-$ & NA \\
\hline Tibia M-L diameter & $24 / 24$ & $20 / 21$ & $-1-$ & NA \\
\hline Platycnemic index & $63 / 61$ & $56 / 58$ & - & NA \\
\hline Tibia length & $369 /-$ & $383 /-$ & $-1-$ & $-/-$ \\
\hline Fibula length & $-1-$ & $-1-$ & $-1-$ & $-1-$ \\
\hline
\end{tabular}

From the data in Table 4 it was possible to calculate the statures and examine the upper femoral shape of the three males from the cists, and the upper tibial shape of two of the males. The three males measured $168 \pm 3.27 \mathrm{~cm} / 5^{\prime} 5^{\prime \prime}$ (Burial 10), $171 \pm 3.37 \mathrm{~cm} / 5^{\prime} 6^{\prime \prime}$ (Burial 4), and $175 \pm 3.37 \mathrm{~cm} / 5^{\prime} 7^{\prime \prime}$ (Burial 5) in height. This gave a mean value of $171.3 \mathrm{~cm}$, which was comparable to the average height of a British male in the Neolithic (see Table 5; also see Roberts \& Manchester 1997). It is likely that the men buried at Dryburn Bridge had been sufficiently well nourished to achieve their full growth potential, and these findings are consistent with the virtual absence of stress indicators and nutritional disorders.

Table 5 Average British male height through time

\begin{tabular}{lc}
\hline Time period & Height $(\mathbf{c m})$ \\
\hline Neolithic & 171.8 \\
Bronze Age & 176.4 \\
Iron Age & 167.8 \\
Anglo-Saxon & 173.2 \\
Medieval & 171.8 \\
British 1979 & 175 \\
\hline
\end{tabular}

The long bone lengths of the child (Burial 11) indicated that ( $\mathrm{s}$ )he was within the correct height range for their age, as they were consistent with the dental development age. In a sickly or malnourished child this is often not the case as although dental development is well buffered against environmental influences, the growth of the rest of the skeleton (with the exception of the clavicles) can be affected. This implies that the child was adequately nourished and reasonably healthy during their short lifetime, although this contradicts the pathological findings.

It was possible to calculate the platymeric index of the three adult males, using the right femur in one case and the left in the other two. All of the femora were platymeric (flattened from front to back in the region of the proximal shaft). Values ranged from 67 to 79 , with the mean being 73 . These findings are consistent with other pre-modern populations where the predominant femoral shape is platymeric (Roberts 1999).

It was possible to calculate five cnemic indices relating to the tibiae of two males (Burials 4 and 5). Values ranged from 56 to 63 . Burial 5 had platycnemic tibiae that were flattened from side to side, and the other male had one platycnemic and one mesocnemic (moderately rounded) tibia. The mesocnemic tibia was the left and it only just fell within that range, so that the difference was barely discernible.

The causes of platymeria and platycnemia are uncertain. The former relates to the degree of anterior-posterior (front to back) flattening of the femoral shaft, and the latter to the degree of medio-lateral (side to side) flattening of the tibial shaft. The extent of flattening is thought to be related to physical activity (Brock \& Ruff 1988). The shape and robusticity of the leg bones are thought most likely to be related to biomechanical factors, activity and terrain (Jackes et al 1997, 649). Flattening of the femora is suggested to be related to greater mechanical stresses on the bone and may be related to a more rugged terrain or more strenuous work.

\subsubsection{Non-metric data}

Tables illustrating the frequency rates of all the cranial and post-cranial non-metric traits recorded can be found in the project archive (Roberts 2002). When interpreting the results, the very small sample size must be taken into account.

Common cranial traits in this group included parietal foramina, open foramen spinosum and foramen of Huschke.

Burial 4 had some unusual features of the cranium. A raised area running from the bregma along the anterior half of the sagittal suture gave the appearance of a small sagittal crest, and there was also a slight bulge along the line of the metopic suture, which had fused and was no longer visible. A slight occipital bun was also present. These anomalies all relate to the fusion of the cranial sutures and 
may be an indication that this had occurred slightly prematurely.

Few post-cranial traits were observed. Those that occurred most frequently were right and left lateral tibial squatting facets and right and left double anterior calcaneal facets. All three adults had one or both traits. Both traits may be related to habitual activity. It has been suggested that an habitual squatting posture, such as that adopted by various populations in India, can cause squatting facets on the tibia, but they have also been seen in fetuses of both Indian and European origin (Kennedy 1989).

Pronounced muscle insertion points on the bone can sometimes indicate heavy or repeated usage of a particular muscle. Burial 5 had a well-developed insertion point for the right deltoid muscle and a large indentation (with lipping around the edges) at the insertion site for the costo-clavicular ligament on the right clavicle. These muscles relate to the shoulder girdle and upper arm, and are involved such activities as lifting, pushing and pulling. Unfortunately, the left humerus was not available for comparison, but there was no such anomaly/ feature on the left clavicle, suggesting that the repeated activity might have been unilateral. The same individual also had a pronounced indentation at the insertion point for gastrocnemius, a muscle used extensively in walking. The right femur was not present for comparison.

The left femur of Burial 10 had a lateral flange, widening and flattening of the lateral aspect of the proximal shaft, and both patellae were elongated laterally. Both of these regions are insertion points for the quadriceps muscle vastus lateralis, which is a powerful extensor of the knee.

\subsubsection{Health and disease}

Dental disease The preservation of the dentition was generally good. Even in cases where the roots and pulp of the crown had degraded leaving only the outer enamel shell it was still possible to examine the teeth for oral pathologies such as caries and dental enamel hypoplasia. A total number of 98 teeth were present from the individuals buried in the cists.

Four carious lesions were identified, giving an overall prevalence rate of $4 \%$. This is comparable to that of $4.2 \%$ observed in European Neolithic populations (Roberts \& Manchester 1997). All affected teeth belonged to the oldest male, Burial 10, who also suffered from a total of six dental abscesses. All of the affected teeth were mandibular molars and all of the lesions observed were large and deep. The abscesses and the caries together would have caused him a considerable amount of pain. A small periapical abscess was observed in Burial 4.

Only one individual, the unfortunate Burial 10, suffered from ante-mortem tooth loss (AMTL), having lost seven teeth prior to death. AMTL generally occurs as a result of periodontal disease, a term used to describe the inflammatory changes that can occur in the soft tissues and bone around a tooth in response to plaque. As the disease progresses, resorption of the alveolar bone of the maxilla and mandible may occur and if the periodontal ligament becomes affected then the result can be the loss of the tooth.

It was difficult to assess the amount of dental calculus (mineralized plaque) present on the teeth because many were loose and broken off at the cervix. Some of the teeth also had the appearance, evident by slight discolouration, of calculus once having been present but subsequently having flaked off either during excavation, cleaning or simply while being handled. Where calculus was observed, it was generally slight (categorization after Brothwell 1981).

No dental enamel hypoplasia was observed. Dental enamel hypoplasia is the name given to the defects, linear grooves and pits, which appear in the enamel of the teeth representing a cessation in amelogenesis (growth and development of the tooth). These defects are considered to be indicators of various types of physiological and even psychological stress. The absence of the condition amongst the individuals from Dryburn Bridge is further evidence that they were well nourished and healthy during childhood.

Traumatic injury Two individuals showed evidence of traumatic injury. Burial 4 had a wellhealed fracture of the right ulna. The bone was well aligned but there was still a considerable amount of callus evident. The position of the fracture, in the lower third of the midshaft, might indicate that it was sustained while warding off a blow, although it was located more distally than the midshaft 'parry fracture' typically associated with this action. The individual had also suffered a compression fracture of the 10th thoracic vertebra and there were secondary degenerative changes associated with that in the same vertebra and also in the 11th and 12th thoracic vertebrae. This type of injury is normally associated with a vertical compression force transmitted directly along the line of the vertebral bodies while the spine is flexed, for example during a heavy fall on the feet or buttocks (Crawford-Adams 1987). In this instance the damage was restricted to the anterior portion of the vertebra, and the posterior ligaments would probably have remained intact. As a result the fracture would have been held in a stable position and there would have been little chance of complications involving the spinal cord.

Burial 10 also had similar types of vertebral fractures in the 12th thoracic and 2nd lumbar vertebrae (the first lumbar vertebra was missing). The actual fractures were less obvious in this instance and the bodies of vertebrae were compressed on the right side. Burial 10 was the older male and it is possible that these fractures were age-related. Again there were secondary arthritic changes in the vertebrae, most noticeably in the 12 th thoracic. In addition to the vertebral fractures, 
this individual also had a well-healed fracture of a left middle rib and a healed fracture of the nasal septum, which had caused it to deviate slightly. This type of injury would have been caused by a blow to the nose, which may, or may not, have been the result of interpersonal violence.

Degenerative joint disease The most frequently identified disease found in any archaeological population is osteoarthritis, which, together with osteophytosis, is often termed degenerative joint disease. The aetiology of the disease is multifactoral, the most common causes being age and repeated stress. It may be primary or secondary, occurring subsequent to traumatic injury when the stresses on a joint have been realigned, or when the actual joint surface has been damaged. In the osteoarchaeological record certain joints do appear to be more susceptible than others, most notably the spine, elbow, shoulder and knee, although the prevalence rates vary between populations (Ortner \& Putschar 1981; Larsen 1984). The system used to categorize the severity of the disease observed in the Dryburn Bridge burials was a modified version of that devised by Jurmain, adapted by King in her analysis of a group of medieval skeletons from the Isle of May (Jurmain 1990; King 1994). Schmorl's nodes were not included in the figures for prevalence rates of spinal degenerative joint disease, and are discussed separately below.

Severe degenerative changes were observed in only one individual, the 45- to 60-year-old male, Burial 10. The right acromio-clavicular and sternoclavicular joints showed evidence of severe porosity, moderate to severe osteophytes and flattening of the joint surfaces. There was also moderate degenerative disease of the right head of humerus and slight changes in the right glenoid fossa. These joints all relate to the right shoulder, and the condition was most likely related to repeated wear and tear on this joint over the years. The same changes were not evident in the left shoulder joint, although the left proximal humerus was not available for examination. This unilateral degenerative joint disease suggests that it was related to a specific righthanded activity that involved repeated movement of the shoulder. Moderate degenerative changes were also identified at the distal ends of the right radius and ulna (the wrist), but there were only slight changes in the carpals and metacarpals of the right hand.

Burial 10 also suffered from spinal joint disease, with all of the 23 vertebrae present being affected. The condition was slight in the upper cervical region, becoming more severe in the region of $\mathrm{C} 6$ to T1. Severe changes were also observed in the lower thoracic and lower lumbar regions.

Burial 4 also suffered from moderate degenerative joint disease of the spine, most of the changes being related to the traumatic injury described above.

Prevalence rates of spinal degenerative joint disease in this small group were as follows: seven out of 12 cervical vertebrae $(58 \%), 15$ out of 28 thoracic vertebrae (54\%) and four out of five lumbar vertebrae $(80 \%)$.

Other spinal pathology Burial 5 suffered from changes to the spine characterized by Schmorl's nodes only. Schmorl's nodes are thought to represent herniations of the contents of the inter-vertebral discs onto the superior and inferior surfaces of the vertebral body. They tend to occur in older juveniles and young adults in whom the discs are still turgid. Often they are the result of a compression force, which might be sustained during heavy lifting or in a fall onto the feet, and they may accompany actual compression fractures. They have also been associated with repeated flexion and lateral bending and may have an underlying congenital cause (Kennedy 1989). Further research into the lesions, which may alter the above interpretation, is currently being undertaken (McNaught, pers comm).

Infectious disease Burial 11 displayed abnormalities of the facial bones that were characteristic of leprosy (illus 15; illus 16). These changes comprised resorption of the nasal spine and the region around and above the central incisors, remodelling of the bone and widening of the nasal aperture and slight pitting of the palatal surface. There was evidence of slight new bone growth on the inner surfaces of the nasal bones, and when the face was looked at in profile it had a dished appearance around the nose and mouth area. The central incisors themselves had been lost post-mortem.

The changes described and observed above are typical of rhino-maxillary syndrome, which is in itself pathognomic of leprosy (Manchester 1989, Aufderheide \& Rodriguez-Martin 1998; C Roberts \& M Lewis, pers comm). In order to make a definite diagnosis of leprosy, some researchers state that characteristic lesions should also be present in the hands, feet and tibiae (D Brothwell, pers comm), although it has been noted that changes in these areas are often very slight and sometimes even absent in juveniles (M Lewis, pers comm). Unfortunately, in this instance, it was not possible to examine other potentially affected regions, as the hands and feet were missing at the time of excavation and both tibiae had been sent previously for radiocarbon dating. The early date of the skeleton also casts doubt on a diagnosis of leprosy. Current perception of the disease is that it was introduced into Europe in the fourth century BC by the armies of Alexander the Great, returning from their campaigns in India. The earliest known example to date in Britain is from the Roman period, although the disease did not become widespread until the 11th century (Roberts \& Manchester 1997).

DNA analysis of portions of the skull in order to attempt to identify the potential leprosy invasion was considered to be the only method available to confirm the morphological changes (Roberts et 


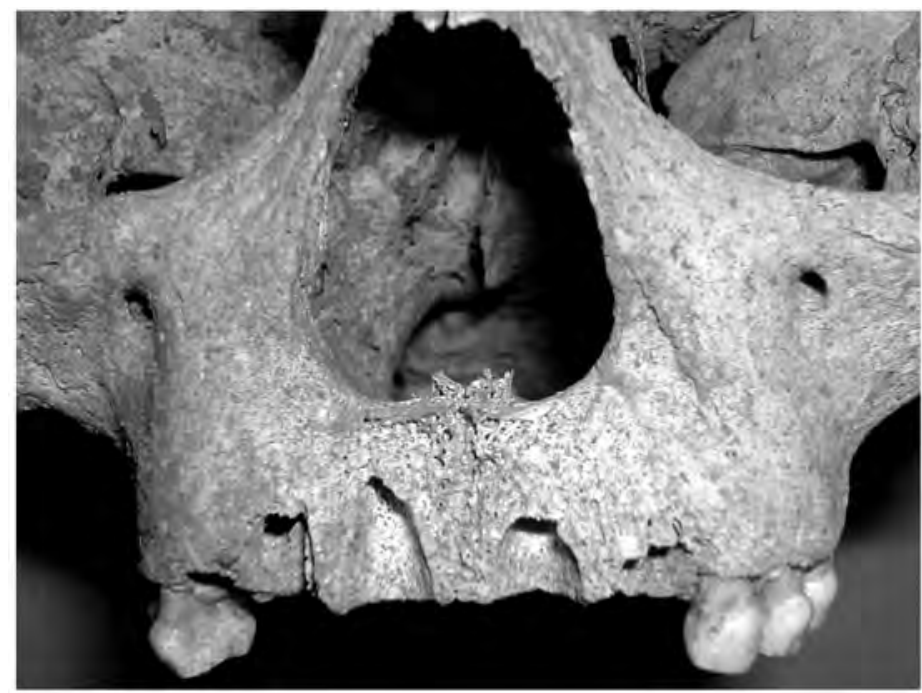

Illus 15 Burial 11; widening and remodelling of nasal aperture; and resorption of the alveolar process of the maxilla

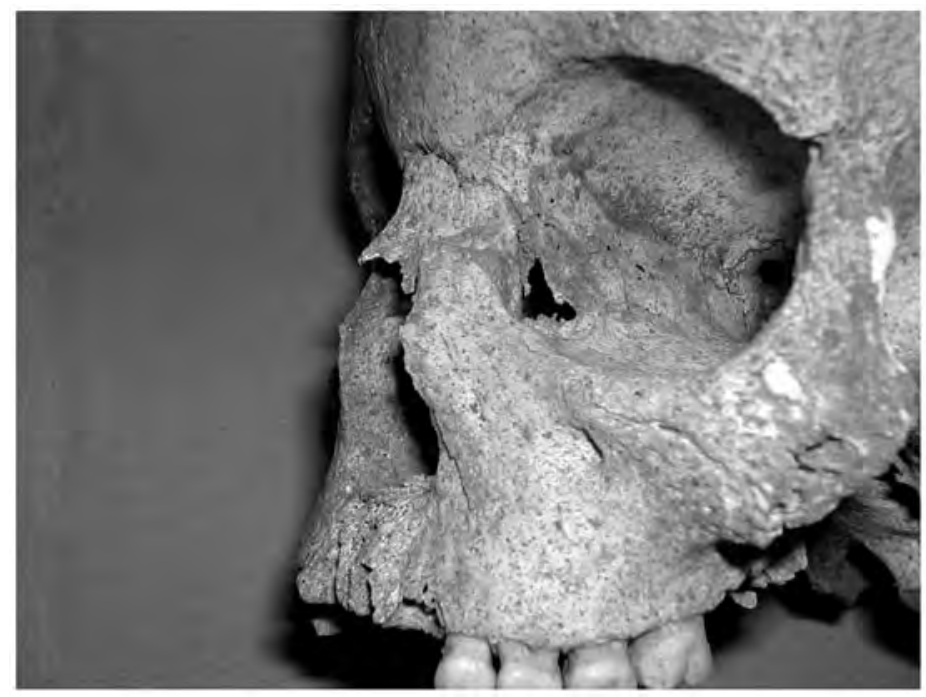

Illus 16 Burial 11; rhino-maxillary changes in profile

al 2004). It was thought that DNA analysis had a reasonable chance of success, as the pathogen is distinctly non-human and therefore not prone to contamination to the same degree as human DNA. Scrapings of bone were taken from the nasal and palatal areas by two independent researchers, Dr Will Goodwin (University of Central Lancashire) and Dr Michael Taylor (Imperial College London). No evidence of Mycobacterium leprae DNA was detected, indicating either that the child had not been infected with leprosy, or that any $M$. leprae DNA which had been present had degraded to the point where it was no longer traceable. One of the researchers, Dr Taylor, noted the presence of $M$. tuberculosis, although the results were not repeatable owing to a lack of further sample material. The skeletal changes observed in Burial 11 were not typical of tuberculosis, but the facial bones can become involved in rare cases as a result of secondary infection from longstanding tuberculosis of the facial skin and soft tissues. Destruction of the nasal bones can occur, as in leprosy (Ortner \& Putschar 1981, 164).

No evidence of infection was identified on the older male buried with the child.

With the exception of the above, only one possible example of a superficial infection was identified. Evidence of periostitis, inflammation of the periosteum surrounding the bone, was observed on the left tibia of Burial 4. Scanty patches of striated lamellar bone were located on the medial aspect of the proximal shaft. This type of remodelled bone indicates an inflammation that had subsided and was no longer active at the time of death. The cause of the inflammation may have been a superficial infection, or even simply direct trauma, perhaps transmitted from the type of soft tissue injury that is common in the lower leg, for example kicks or bangs to the shins. There 
was no evidence to suggest that it was associated with a more serious widespread specific infection.

Metabolic disorder The skeletons were remarkably free from stress indicators such as dental enamel hypoplasia, and iron deficiency anaemia (Larsen 1984; Stuart Macadam 1992; Grauer 1993). The one possible exception to this was Burial 5 who displayed some of the characteristics associated with porotic hyperostosis. Porotic hyperostosis is one of the skeletal manifestations of iron deficiency anaemia, whereby the skull becomes thickened and the outer surface pitted. There are many causes of iron deficiency anaemia, amongst the most common being lack of absorbable iron in the diet and a high pathogen load within the body (Stuart Macadam 1992). The changes observed in Burial 5 were, however, not very convincing, with porosity being the only feature evident. Although this was fairly widespread, affecting the posterior part of the frontal bones, the medial parts of the left and right parietal bones and all of the occipital except for the most lateral part, it was not particularly severe and neither was there any thickening of the cranium.

\subsubsection{Burial catalogue}

\section{Skeleton number: 4}

Preservation: Fair. 60\% complete. Minimal surface erosion. Cranium intact.

Elements present: Cranial: intact cranium with exception of fragmented ethmoid.

Dentition: All maxillary dentition except left central incisor and 2nd premolar, lost post-mortem (pm). All mandibular dentition except right central incisor and canine and left lateral incisor, lost pm.

Post-cranial: Right scapula and clavicle, left and right humerus radius and ulna, left ilium and pubis, right femur and patella, left and right tibia, fibula, min no six left and five right ribs, 5 th metacarpal, left talus, one hand phalanx, six thoracic, one lumbar and three sacral vertebrae.

Age at death: $\quad 35-45$ years

Sex: Male

Stature: $171.6 \pm 3.37 \mathrm{~cm}\left(5^{\prime} 6^{\prime \prime}\right)$.

Pathology: Dental disease, healed fracture of the right ulna, healed compression fracture of T10, degenerative joint disease of the spine, mild porotic hyperostosis, slight periostitis left tibia.

Non-metric traits: Bilateral parietal foramen, left ossicle at parietal notch, bilateral mastoid foramen extrasutural (and accessory foramen), posterior condylar canal open, open foramen spinosum, accessory palatine foramen, absent zygomatico-facial foramen, accessory supra-orbital foramen, and occipital bun. Right Allen's fossa, bilateral lateral tibial squatting facets.

Additional information: Left femur previously sent for C14 dating (Lab Code GU-1406).

Skeleton number: 5

Preservation: Good, although some fragmentation and cranium glued back together. 90\% complete. Minimal surface erosion.
Elements present: Cranial: left and right mandible, frontal, parietal, occipital, temporal, sphenoid, and zygomatic bones. Fragment of right maxilla, incomplete ethmoid, vomer.

Dentition: All maxillary and mandibular dentition in very good condition.

Post-cranial: All postcranial elements present except the right femur, right patella, left lunate, pisiform, scaphoid, trapezoid and hamate, right lunate, triquetrum, pisiform, trapezoid, capitate, two cervical, two thoracic and all lumbar vertebrae.

Age at death: $30-40$ years (closer to 30 than 35-40).

Sex: Male.

Stature: $175 \pm 3.37 \mathrm{~cm}\left(5^{\prime} 7.5^{\prime \prime}\right)$.

Pathology: Schmorl's nodes.

Non-metric traits: Left parietal foramen, bilateral foramen of Huschke, precondylar tubercle, left double anterior condylar canal, left bridging of supra-orbital notch. Bilateral lateral tibial squatting facet, acetabular crease, left acromial articular facet, bilateral double anterior calcaneal facet. Small mandibular tori, larger on right.

Additional information: Well developed insertion for right deltoid (left incomplete). Also enthesopathy/large indentation at insertion for right costo-clavicular ligament, not present on left. Pronounced indentation for gastrocnemius left distal femur.

\section{Skeleton number: 10}

Preservation: Good. $>75 \%$ complete. Cranium intact except for defect in right parietal. Minimal surface erosion.

Elements present: Cranial: all elements present. Dentition: right maxillary lateral incisor, canine and 1st molar, central incisor and both premolars lost pm, 2nd and 3rd molars lost am. Left maxillary canine and 1st premolar, incisors lost pm, 2nd premolar and all molars lost am. All right mandibular teeth present, but crown of canine broken off and root has polished appearance. All left mandibular teeth present except for 2nd molar. Canine as on right side.

Post-cranial: all elements present except sternum, left pubis, left scaphoid, lunate and pisiform, left 4th and 5th metacarpals, right pisiform, trapezoid and 1st metacarpal. Left talus, cuboid, navicular, all cuneiforms and 4th and 5th metatarsals. L1 and S5.

Age at death: $45-60$ years.

Sex: Male.

Stature: $168 \pm 3.27 \mathrm{~cm}\left(5^{\prime} 5^{\prime \prime}\right)$

Pathology: Degenerative joint disease, spinal joint disease, healed fracture of rib, fractured nasal septum?, dental disease - caries and abscesses.

Non-metric traits: Ossicle at lambda, right ossicles in lambdoid, bilateral parietal foramen, foramen of Huschke, mastoid foramen absent, right double anterior condylar canal, bilateral open foramen spinosum, maxillary foramen, accessory supra-orbital foramen. Right acromial articular facet, double anterior calcaneal facet, C7 transverse foramen bipartite.

Additional information: Right femur previously sent for C14 dating (GU-1408). Ossified thyroid and cricoid cartilage. Lateral flange and noticeable flattening of proximal shaft of femur. Slender although muscle insertions rugged.

\section{Skeleton number: 11}

Preservation: Cranial good, post-cranial fair. $40 \%$ complete. Minimal surface erosion to cranium, moderate to mandible and post-cranial remains.

Elements present: Cranial: all elements.

Post cranial: Right scapula, left clavicle, right and left 
humerus, radius, left ilium, pubis, right femur and fibula, min no seven left and eight right ribs, left talus, one thoracic and one lumbar.

Age at death: $6-8$ years.

Sex: NA

Stature: NA.
Pathology: Possible congenital abnormality of the facial bones, possible infectious disease affecting maxillo-nasal region.

Non-metric traits: NA.

Additional information: 'Tibiae' (right and left?) previously sent for C14 dating (GU-1409). 


\section{Early Prehistoric Activity: Radiocarbon Dates from the Human Remains}

In 1979/80, samples of human bone from Burials 4, 10 and 11 were submitted for dating to the Department of Chemistry, University of Glasgow. Table 6 provides the determinations returned, containing calibrated ranges at 2-sigma ( $95.4 \%$ confidence) based upon both the original lab error quoted (as cited by eg Sheridan, in Clarke \& Hamilton 1999, 196) and the adjusted errors recommended by Ashmore (Ashmore et al 2001). Calibrated ranges based upon original errors were calculated using OxCal v 3.5 (Bronk Ramsey 2000), and those relating to the adjusted errors are the ranges produced previously (Ashmore et al 2001).

The scale of the errors associated with these determinations allowed the burials to be dated only in broad terms. To offset the problems associated with these dates, fresh samples were submitted for dating from each of the four skeletons. Samples were submitted to SUERC (see Section 2.2.3 for discussion of the rejection of an intermediate set of dates). The results are collated in Table 7, with calibrations obtained by SUERC using OxCal v 3.5 (Bronk Ramsey 2000).
These determinations have much tighter calibrated ranges than can reliably be interpreted for the original radiocarbon dates, and all fall almost wholly within the calibrated ranges of the earlier dates. The date ranges of the four burials are generally consistent, albeit that a result from one of the dated samples from Burial 5 (SUERC-4072) has a slightly younger range than the others. The results indicate that all four individuals most probably died within the period 2300-2000 cal BC. Assuming that the Beaker vessel recovered from above the burial chamber in Cist 2 formed part of the burial rites associated with Burials 10 and 11, its implied date fits well with the dates of other dated Beaker vessels (Sheridan in Section 4.3, illus 14).

There is no dating evidence to indicate a chronological sequence of burial within either cist. It is not justifiable to attempt to combine the radiocarbon dates from the burials within each cist, based upon the assumption of contemporaneity of death of the two individuals, in order to tighten the calibrated range (cf Ward \& Wilson 1978). This is because it

Table 6 Radiocarbon dates from Cists 1 and 2; 1979/1980

\begin{tabular}{lllllllll}
\hline Lab no & $\begin{array}{l}\text { Sample } \\
\text { context }\end{array}$ & Material & $\begin{array}{l}\text { Lab } \\
\text { Age }\end{array}$ & $\begin{array}{l}\text { Lab error } \pm \\
\text { 1 sigma }\end{array}$ & $\begin{array}{l}\text { 2-sigma range } \\
\text { using lab } \\
\text { error (cal Bc) }\end{array}$ & $\begin{array}{l}\text { Adjusted } \\
\text { Error } \div \\
\text { sigma }\end{array}$ & $\begin{array}{l}\text { 2-sigma range } \boldsymbol{\delta}^{13} \mathbf{C}(\%) \\
\text { using adjusted } \\
\text { error (cal BC) }\end{array}$ \\
\hline GU-1406 & $\begin{array}{l}\text { Burial 4, Femur } \\
\text { Cist 1 }\end{array}$ & 3850 & 160 & $2900-1800$ & 225 & $2900-1600$ & -21.4 \\
GU-1408 & $\begin{array}{l}\text { Burial 10, Femur } \\
\text { Cist 2 }\end{array}$ & 3620 & 85 & $2300-1700$ & 120 & $2400-1600$ & -20.6 \\
GU-1409 & $\begin{array}{l}\text { Burial 11, Tibiae } \\
\text { Cist 2 }\end{array}$ & 3550 & 80 & $2140-1680$ & 110 & $2200-1600$ & -23.1 \\
\hline
\end{tabular}

Table 7 Radiocarbon dates from Cists 1 and 2; 2005

\begin{tabular}{|c|c|c|c|c|c|c|}
\hline Lab no & Sample context & Material & Lab age & $\begin{array}{l}\text { Lab error } \pm \\
1 \text { sigma }\end{array}$ & $\begin{array}{l}\text { 2-sigma range } \\
\text { (cal bc) }\end{array}$ & $\delta 13 \mathrm{C}(\%)$ \\
\hline $\begin{array}{l}\text { SUERC-4071 } \\
\text { (GU-12240) }\end{array}$ & Burial 4, Cist 1 & L Ulna & 3765 & 35 & $2290-2030$ & -20.4 \\
\hline $\begin{array}{l}\text { SUERC-4082 } \\
\text { (GU-12251) }\end{array}$ & Burial 4, Cist 1 & Rib and scapula & 3760 & 40 & 2300-2030 & -20.1 \\
\hline $\begin{array}{l}\text { SUERC-4072 } \\
\text { (GU-12241) }\end{array}$ & Burial 5, Cist 1 & L Humerus & 3615 & 40 & $2140-1820$ & -21.8 \\
\hline $\begin{array}{l}\text { SUERC-4083 } \\
\text { (GU-12252) }\end{array}$ & Burial 5, Cist 1 & L Radius & 3725 & 35 & $2280-1980$ & -21.0 \\
\hline $\begin{array}{l}\text { SUERC-4078 } \\
\text { (GU-12246) }\end{array}$ & Burial 10, Cist 2 & R Ulna & 3755 & 35 & 2290-2030 & -21.2 \\
\hline $\begin{array}{l}\text { SUERC-4079 } \\
\text { (GU-12247) }\end{array}$ & Burial 11, Cist 2 & $\begin{array}{l}\text { Thoracic } \\
\text { vertebra }\end{array}$ & 3720 & 35 & 2280-1970 & -21.7 \\
\hline
\end{tabular}


cannot be demonstrated on archaeological grounds that the burials contained in each case died at the same time (discussed further in Section 6.2).

The determinations from the skeletons from the two cists are statistically indistinguishable, suggesting that these burials structures were in use broadly, if not exactly, at the same time. However, this does not mean that the cists were necessarily constructed at the same time: it cannot be assumed that a full record of burial within each cist remained at the time of excavation, and that the primary burials for which each cist had been built were preserved. 


\section{Early Prehistoric Activity: Discussion}

\subsection{Mesolithic}

Dryburn Bridge has produced a range of features and artefacts that considerably pre-date the use of this location as an Iron Age settlement. These indicate sporadic activity over a long time period. It is not uncommon for large-scale excavations such as this to reveal traces of earlier activity (for example the Beaker activity at St Germains: Alexander \& Watkins 1998).

The microlithic component of the chipped assemblage attests to Mesolithic activity at the site. Finlayson (Section 4.1) has proposed that Dryburn Bridge was the site of a camp. It is unfortunate, given the lack of coherent evidence for Mesolithic settlement in the Lothian plain, that little more can be said of the nature of the activities at Dryburn Bridge (G Warren, pers comm). This is because, where their provenance is known, the artefacts were found redeposited within Iron Age or superficial contexts. The contexts of the microlithic pieces are known for the most part, and these tend to concentrate in the south part of the excavated area, although they do occur across much of the site. Our understanding of the nature of the Mesolithic presence in this area should be considerably enhanced as a result of the recent discoveries of a substantial Mesolithic post-built structure and associated artefacts at East Barns (NGR: NT 7121 7686), c $2 \mathrm{~km}$ north-west of Dryburn Bridge (DES 2003, 56-7) and other finds made during the upgrading of the A1 road between Haddington and Dunbar in 2001-2 (G MacGregor, pers comm).

\subsection{Late Neolithic/Early Bronze Age}

The extent of Late Neolithic/Early Bronze Age activity present at Dryburn Bridge is debatable. A minimal interpretation can be put forward, based purely upon what can be confidently dated by diagnostic material remains. In this scheme, features attributable to this span would include two burial cists, pits containing pottery and other chipped stone artefacts re-deposited in later contexts.

However, many of the features excavated across the site are undatable and, while in most cases they could well relate to the Iron Age settlement, an earlier origin for at least some cannot be ruled out. Features possibly associated with Late Neolithic/ Early Bronze Age activity include (in decreasing order of likelihood): a cluster of pits spatially associated with those containing Impressed Ware pottery, which may represent an activity area or possibly even the remains of a light structure; House 4; and pit 0104.

The discovery of Impressed Ware pottery at Dryburn Bridge fits in with what is known of its distribution and contexts of recovery in south and east Scotland (Cool and Cowie, Section 4.2; also MacSween 1999, 79). As noted previously (MacSween 1999), where contexts have been established for Impressed Ware, they are normally pits (a recently published example being Cameron's 2002 excavations at Dubton, Brechin). Although the specific functions of the Dryburn Bridge pits are not known, it is perhaps significant that at least one (EDP) contained sherds belonging to more than one vessel. The possible structural association mentioned above would, if accepted, provide a good context for the small assemblage from Dryburn Bridge.

The two burial cists form a distinctive feature of the site. Each cist contained two individuals, with an articulated burial overlain by the disarticulated remains of a second. Three of the skeletons were of mature adult males. These men had suffered from a range of traumatic injuries, dental problems and arthritic conditions typical of physical lifestyles and advancing years. The fourth skeleton was of a child who had suffered from an undiagnosed infectious disease.

The radiocarbon evidence indicates that both cists were in use between approximately 2300 and 2000 cal BC, during the period in which the Beaker burial tradition occurred widely across the British Isles (Sheridan in Section 4.3; Kinnes et al 1991). Cist 2 at Dryburn Bridge was associated with a Beaker vessel and, although the vessel came from above and not within the burial cist, the feature can be interpreted reasonably as falling within the Beaker burial tradition. Cist 1 cannot be so readily interpreted as a Beaker tradition burial, because of the lack of a Beaker vessel from within the funerary structure.

The close similarities between the character of the funerary structures and the burial forms of the two cists indicate beyond reasonable doubt that these were conceptually linked features. Given their spatial proximity and the comparable radiocarbon dates for the human skeletal remains, there seems little reason to doubt that the two cists relate to the same community, and that they formed broadly contemporary elements of the landscape.

The nature of the burial form merits consideration in more detail. There is more than one possible trajectory by which the final burial layout recovered by excavation in each cist could have been reached, and these are significant in terms of understanding whether the cists were repeatedly reused or each 
contained the outcomes of a single burial event. Three hypotheses can be constructed to explain the burial form within each cist:

1 The disarticulated skeletons represent the primary burials within each cist. These remains were disturbed and re-deposited over the remains of secondary articulated burials within each cist. This hypothesis requires two separate acts of burial activity.

2 Each cist contains two skeletons, reflecting a single burial event. This implies that in each case a corpse was interred along with the defleshed and disarticulated remains of a second individual.

3 The disarticulated remains represent secondary burials within each cist. This hypothesis also requires two burial events.

The osteoarchaeological evidence indicates that the disarticulated remains appear to represent those of individuals who had been de-fleshed elsewhere after their deaths, before partial skeletal remains were incorporated into the cists (cf Metcalf \& Huntington 1991). The selective nature of the disarticulated remains of Burials 4 and 11, in particular the absence of small bones, indicates that they were introduced into each cist as partial skeletons. There is no reason to regard the absence of small bones as a preservation bias. The potential circumstance of the disarticulated remains representing those of disturbed primary inhumations removed whole from the cists before partial remains of those skeletons were reinterred over the secondary burials is an alternative, if more complex and less satisfactory, explanation.

Combined with the osteoarchaeological evidence, the occurrence of the same burial form in adjacent cists at Dryburn Bridge suggests that the cists were not opportunistically reused for secondary burials, with the disordered remains of primary burials deposited back over the secondary inhumations. This reinforces the idea that the burial form reflects a meaningful pattern of careful, structured deposition. To invoke an explanation of essentially opportunistic reuse would run contrary to the widespread archaeological and anthropological evidence to suggest that the form and rites of burial were closely controlled and ritualized in prehistory, and that human remains were carefully curated (eg Parker Pearson 1999b). Thus hypothesis 1 cannot be sustained without special pleading.

Robertshas noted(Section 4.4) thateither exposure/ excarnation or burial/exhumation processes could have led to the loss of certain skeletal elements of Burials 4 and 11 through a variety of potential processes. Equally, however, those disarticulated elements introduced to the cists may reflect deliberate selection through ritual considerations it is now all but impossible to establish.

There was no certain archaeological evidence at the site for other graves or mortuary structures or enclosures that might have formed the loci for the de-fleshing of those skeletons (4 and 11) subsequently transferred to the burial cists. It is just possible that the four-post arrangement only $c 5 \mathrm{~m}$ east of Cist 1 (illus 3 and illus 47, G) was not an element of the Iron Age settlement (Section 7.5), but rather of a raised timber excarnation platform. Others (Barclay \& Russell-White 1993, 178-82) have considered the archaeological evidence for the excarnation rite and excarnation platforms, in the context of the Balfarg/Balbirnie excavations. The dialogue within that report between Hogg and Barclay (Barclay \& Russell-White 1993, 169-75) as regards the form of the excarnation structures present within two enclosures at that site is instructive, as it centred on whether four- or six-post foundations were present (as proposed by Hogg) or a series of two-post erections (preferred by Barclay). The plough-truncated remains of such a morphologically simple and undatable structure at Dryburn Bridge are interpretable in countless ways (Section 7.5), but the possibility of a pre-settlement origin and a use associated with the exposure of corpses should not be ruled out.

It thus can be accepted reasonably that the stratigraphic relationships between the skeletons within each cist reflect the true order in which the bodies first entered them. However, the archaeological evidence as to whether one or two burial events is represented in each cist is less definitive (hypotheses 2 and 3). There is some possible evidence for reworking of the burial structures that might support multiple burial events. The breakage of one of the capstones of Cist 1 could have occurred during an attempt to re-open the burial chamber, with some fragments used to reseal it and with the remainder discarded in the backfill of the pit. Contrastingly, no evidence was detected for a re-cut within the upper backfill material. The south-west wall slab and small slab inserted at the north-east corner of Cist 1 are unusual and may reflect re-arrangement of the cist particularly given its strange off-centre position within the base of the construction pit. However, none of this provides positive evidence for reworking of the cist, and Beaker burial cists with asymmetrical walls are known elsewhere (eg Balblair, Beauly: Hanley \& Sheridan 1994, 132, illus 3).

For Cist 2, the evidence of sequence is more ambiguous still. Here, the excavators interpreted the stones overlying the cist cover around the periphery of the pit as rough paving. However, the attitude of these stones was distinctive, for the most part with one side lying flush with the edge of the grave pit and with narrower, and in several cases pointed, edges facing towards the centre of the pit. This suggests that they might alternatively be interpreted as collapsed or pulled over upright stones that had formerly lined the upper edge of the construction pit, possibly even defining a two-tier burial chamber which was dismantled and filled in immediately before the final closure of the burial chamber. The positioning of the Beaker vessel above 
the cist and the slabs is noteworthy. It seems to have been deposited immediately before the final infilling of the construction pit. Beakers are well known as the intact contents of cist burials, and there are other contexts where they appear to have been smashed over burials (Sheridan 1997) although, as noted by Sheridan (Section 4.3), the particular context of the Dryburn Bridge Beaker is highly unusual. However, all the above could be explained within a single burial event, and as with Cist 1 no evidence for re-cutting was detected in the upper pit backfill to suggest re-opening of the cist.

Ultimately, the simplest and most likely explanation for the burial form is that it represents in each cist a single burial event (hypothesis 2). This interpretation is consistent with all the available structural, stratigraphic and radiocarbon dating evidence, and indicates the close similarity of the burial form in the cists as structured and meaningful. Hypothesis 3 lacks certain supporting evidence for reworking of the burial structures.

The burial rite in the Dryburn Bridge cists thus comprised the interment of an articulated corpse accompanied by the partial and disarticulated remains of a second individual. This raises wider issues as to the potential relationships of those buried. The presence of multiple bodies within a single burial structure could be explained as a reflection of familial relationships (cf Petersen 1973). The fact that three of the four individuals were adult males, with the other being a juvenile of unknown gender, may be significant in terms of social relations over the period represented by the skeletons. Although the sample is far too small to be statistically significant, it does appear to reflect the general trend for Beaker cist graves to be associated (at least in eastern Scotland) with the burial of males, particularly mature adults aged 35 and over (Bruce, in Shepherd 1986, 17-18).

The two cist burials at Dryburn Bridge can be added to the dense scatter of such discoveries in the immediate vicinity. Four separate discoveries of Beaker burials have been made within a kilometre of the site, three to the south-east and east, towards Skateraw (1, Stevenson 1940; Clarke 1970, nos 1647-8; 2, DES 1958, 39; 3, Close-Brooks et al 1979), and one to the north-west at East Barns (PSAS 1901). Other findspots within $3 \mathrm{~km}$ of Dryburn Bridge comprise West Pinkerton (Stevenson 1939), Thornton (Childe \& Lowe 1939; Clarke 1970, no 1635) and Thurston Mains (Stevenson 1940; Clark 1970, no 1636). Within this local context, the Dryburn Bridge cists are unusual in the depth to which they had been sunk. One exception may have been Skateraw 3, where road make-up rendered it impossible to assess the real depth of subsoil (CloseBrooks et al 1979, 1).

Even this small group displays a wide range of burial form. Skateraw 1 and 3, East Barns and Thornton all contained single inhumations, whereas West Pinkerton and Thurston Mains contained two bodies. Those inhumed comprise men and women, as well as a child at Thornton. It was suggested that the body within the Skateraw 2 cist had been decomposing at the time of its interment, because the arms were detached and had been placed on the wrong side of the body (DES 1958, 39). While they do occur less commonly than single burials, Beaker burials displaying double inhumations are not rare in Scotland: for example discoveries in north east Scotland at Hillhead of Fechil (Clarke 1970, no 1451; Shepherd 1986, 29, 36) and Broomend of Crichie (Chalmers 1870; Davidson 1870; Clarke 1970, nos 1433-7). Of those close to Dryburn Bridge, Thurston Mains (Stevenson 1940) contained the remains of two articulated adult females, identified by the excavator as apparently interred at the same time. (Those skeletons have recently been dated by radiocarbon methods to within the same age ranges as the Dryburn Bridge burials (illus 14) and, whilst the determinations returned are not identical their combination does not fail a chi-squared test, suggesting that they are not statistically significantly different and could relate to the same burial event.) By contrast, the form of West Pinkerton (Stevenson 1939) grave offers remarkable similarities to the Dryburn Bridge discoveries, containing the remains of two mature males, one articulated and the second disarticulated. Stevenson suggested that the burials had been deposited on two separate occasions, with the disarticulated remains being those of a disturbed primary inhumation. This explanation reflects a hypothesis specifically rejected for the Dryburn Bridge cists although in the absence of a published report on the West Pinkerton Thurston Mains skeletal remains it is not known if the disarticulated remains were of a whole or partial skeleton. The skeletal remains from West Pinkerton would merit revisiting through osteoarchaeological examination and radiocarbon dating.

The wide variety of burial form represented by Beaker burials, even in the vicinity of Dryburn Bridge, suggests that particular burial forms and rites may have been context-specific, and determined by any number of unknowable factors such as the status or role of the individuals in life or the particular circumstances of death. West Pinkerton and Dryburn Bridge together appear to demonstrate that this particular burial form was at least locally significant in both time and space.

\subsection{Continuity and memory?}

It seems likely that the activities represented by the Impressed Ware pottery pre-date the burial cists, although their date ranges do overlap. Based upon the radiocarbon dating evidence for comparable material from Meldon Bridge 07919156829 and other sites discussed by Cowie (Cowie 1993a; Cowie 1993b), a Late Neolithic date focusing upon the early third millennium cal BC would seem appropriate for the Impressed Ware pottery. The dates obtained 
from the human remains in the cists concentrate upon the period 2300-2000 cal BC at 2-sigma.

The latest pre-settlement activity, represented by the burial cists, probably took place over a millennium before the establishment of the Iron Age settlement (although an absolute date for the foundation of the latter was not established). Although there is conclusively no case for claiming direct continuity between the settlement and this earlier activity, the fact cannot be passed over that, as far as we can tell, the positions of the Early Bronze Age burial cists appear to have been respected during the lifetime of the Iron Age settlement, and indeed appear to have formed a focal point for a cemetery zone within the settlement (Section 7.6). Unless the juxtaposition is entirely coincidental, it appears that the Early Bronze Age burial cists were interpretable to the occupants of the Iron Age settlement. This presumes that their positions were in some way marked above the ground. The possibility that the construction pits of the cists were signalled by upright timbers or stones with their final closure has been mentioned above. If so, it seems clear that a timber marker would not have been visible a millennium later unless it had been repeatedly replaced (for which there is no supporting archaeological evidence). Alternatively, it is possible that the positions of the cists had been marked by boulders, cairns or barrows, and that these remained visible when the Iron Age settlement was founded. It is noteworthy that a cist cemetery recently discovered at Holly Road, Leven, Fife contained a cist, of similar form to the Dryburn Bridge examples, which was sealed beneath a large marker boulder (Cist J: Lewis \& Terry 2004, 28-30). If any such features had been present at Dryburn Bridge they must have been removed subsequently, either by levelling, robbing, clearance or plough-truncation (or a combination of factors). Despite the uncertainty as to how the cist burials remained visible above ground, the conceptual link between them and the Iron Age cemetery seems unlikely to be fortuitous. 


\section{The Iron Age Settlement: Excavation Results}

\subsection{Enclosing works}

\subsubsection{Outer enclosure (illus 3; illus 17; illus 18; illus 19)}

Description The enclosure visible on the aerial photographic coverage was fully exposed over the course of the two excavation seasons. The foundation for a palisade trench enclosed a sub-oval area measuring $c 87 \mathrm{~m}$ long (north/south) by up to $50 \mathrm{~m}$ at its widest point (illus 3 ), with a total length in the order of $c 260 \mathrm{~m}$. Where better preserved, generally to the south and east, this palisade trench was $c$ $0.7-0.8 \mathrm{~m}$ wide and $0.5-0.7 \mathrm{~m}$ deep, whereas to the north it diminished in scale to less than $0.3 \mathrm{~m}$ wide and deep. These varying dimensions probably reflect differential plough-truncation across the site as a whole rather than any differences in the scale of the features as originally constructed. Certain sections of the palisade trench were fully excavated, whereas others were only partly examined to reveal the stone packing. The packing was a continuous feature of the palisade trench, and in places individual postsockets could be defined within it. Where fully excavated, the palisade trench possessed a roughly squared profile; and where determined, it appears that timber uprights had been set in the trench at $0.3-0.4 \mathrm{~m}$ intervals. Apart from at the entrances, there was very little evidence for realignment or recutting of the palisade trench (although this does not rule out the replacement of posts or, at least, minimal adjustments to the pre-existing packing).

There were two entrances, and potentially the blocked remains of a third, all on the east side of the enclosure. The north-east entrance (illus 17; illus 18) was the most substantial and complex. On either side expanded palisade terminals defined a passage $c 2 \mathrm{~m}$ wide. Excavation demonstrated two structural phases to the substantial stone-packed terminal post-holes, with primary settings located just inside the boundary alignment and secondary sockets positioned along the palisade alignments.

These phased post-holes probably relate to two successive gateways. This entrance formed one component of a complex of features at this location, including the entrance to the inner enclosure (Section 7.1.3), and their interpretation as a group is returned to later (Section 7.1.4). The south-east entrance was also defined by a $c 2 \mathrm{~m}$ wide break in the palisade trench alignment (illus 19), with the likely presence of a gate defined by post-holes set in the palisade terminals. This entrance displayed no evidence of repair or rebuilding.

These two entrances lay just under $50 \mathrm{~m}$ apart. The site records document the possible presence of a blocked middle entrance, based upon two pits or postholes located $c 2 \mathrm{~m}$ apart exactly midway between the two confirmed entrances (indicated on illus 3). The southern feature abutted the palisade trench, but the stratigraphic relationship between the two could not be established. The presence of this third

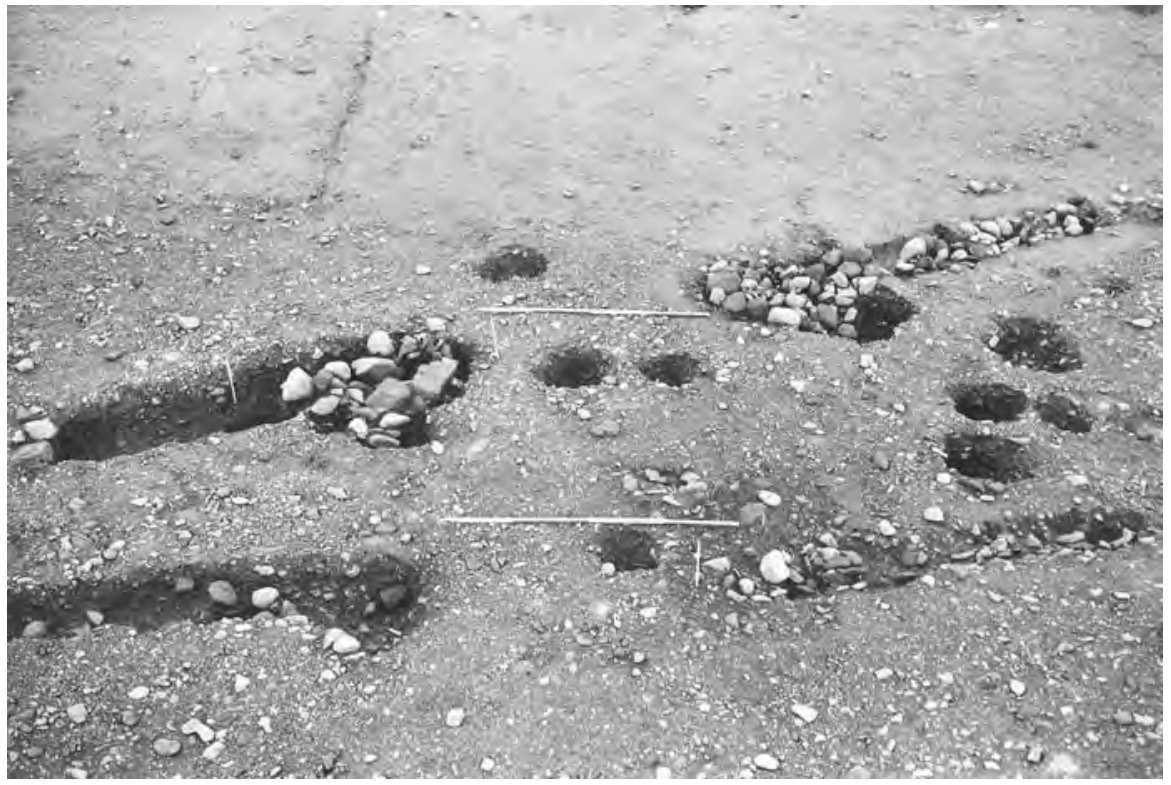

Illus 17 Looking east towards inner enclosure entrance in foreground and outer enclosure north-east entrance in background 


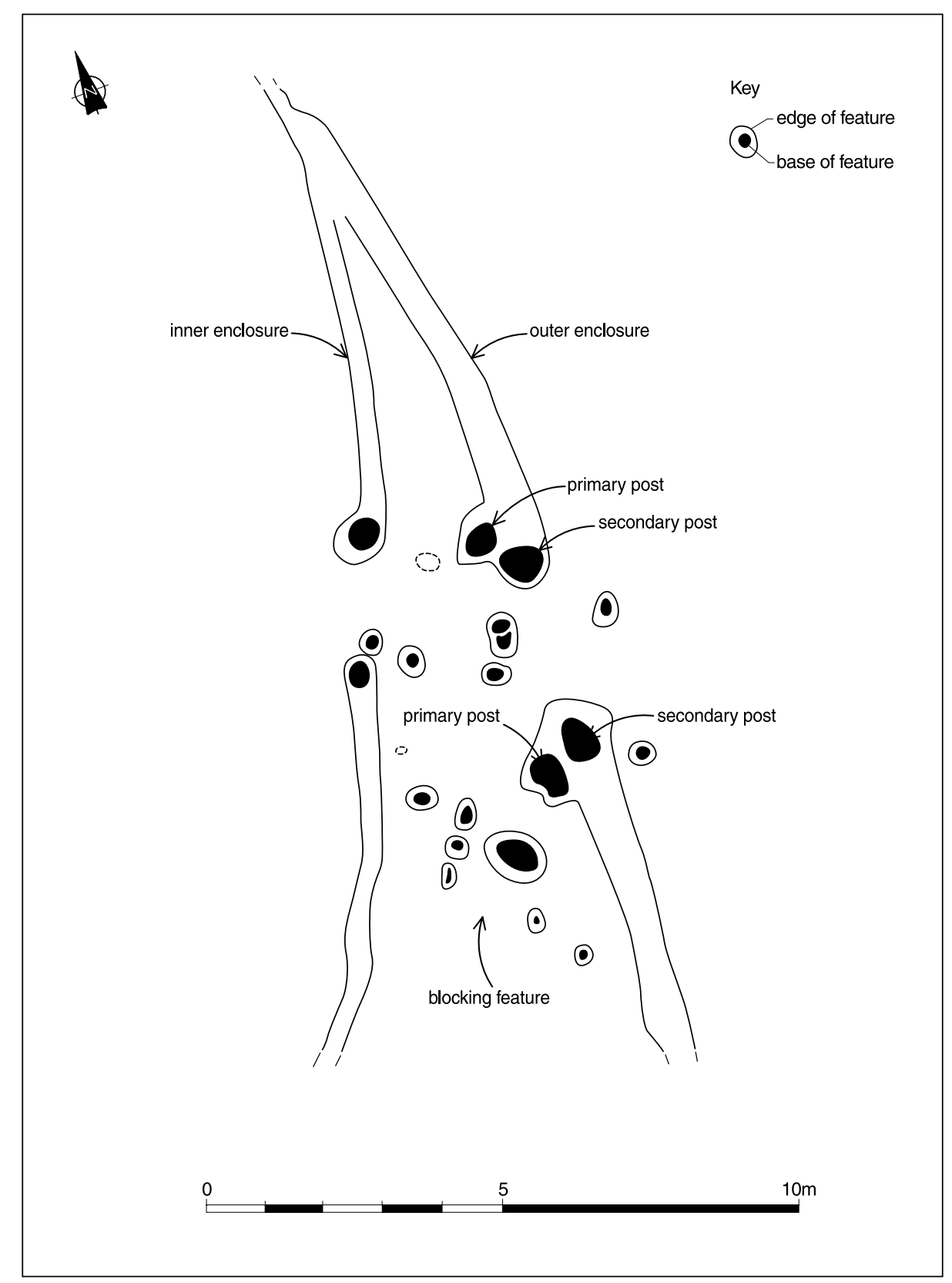

Illus 18 Inner enclosure entrance and outer enclosure north-east entrance; plan

entrance had been surmised by the excavators on the basis of abrupt changes in the width of the palisade trench (where a narrow section of trench was present between two wider sections), combined with variations in the character of the stone-packing. However, it is evident from the records that the excavators experienced considerable difficulty in providing any secure stratigraphic evidence to confirm the conjectured initial entrance here, such as by determining whether different sections of palisade were built by different teams to different specifications, or whether stretches were superimposed and cut each other. The possible existence of the middle entrance was at first proposed (Pollock \& Triscott 1980), but was subsequently dismissed by the excavators (hence its absence from the site plan published in Triscott 1982). Despite this, there are good a priori reasons (discussed further in Section 7.2.1) for believing that an entrance may once have been present at this location, and the former existence of such a feature is here considered possible but unproven.

Finds recovered from the outer enclosure palisade trench included: coarse pottery, mainly from around the north-east and putative middle entrances (Cat nos 1, 12-26, 29; see illus 58 for Cat nos 1 and 18), and a range of animal bones. No coarse stone items were recovered, and the absence of items reused as packing in the palisade trench is worth noting, contrasting as it does with evidence from the roundhouses and inner enclosure boundary. 


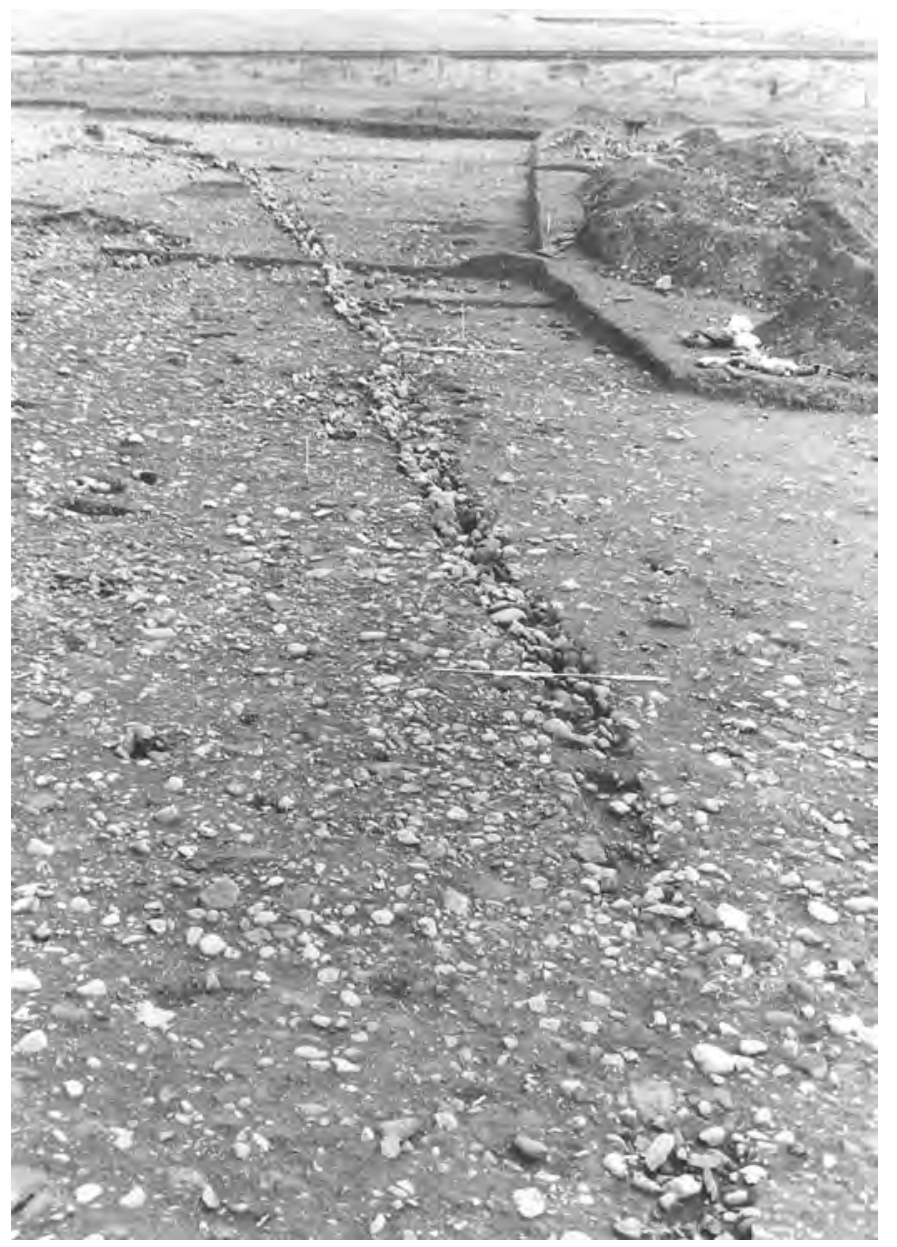

Illus 19 Outer enclosure east side; with south-east entrance in foreground

Stratigraphic and spatial relationships The palisade slot only intersected with a small number of features around its circuit. In the north-west it was truncated by two pit graves (Burials 1 and 14) and abutted by two more (Burials 7 and 13). To the west it was overlain by components of Houses 3 and 8 . At the south-west corner its relationship with linear feature M69 had been obscured by the successive insertions of a dog burial (M43) and a modern field drain. These truncated both points of intersection between the palisade trench and M69, although the dog burial had clearly truncated the palisade trench. However, artefactual evidence from the linear feature (Section 7.8.1) suggests it too must have been cut through the palisade. The relationship between the inner and outer enclosure boundaries is considered separately in Section 7.1.4 and Section 7.2.2.

\subsubsection{Possibly related external works (illus 3)}

Other linear features outside the outer enclosure appear to represent the foundations of fence lines that might have been associated with it, although neither stratigraphic nor dating evidence is available to confirm that hypothesis.
A $c 14 \mathrm{~m}$ length of a slight linear feature was located running $c 3 \mathrm{~m}$ outside and parallel to the southern boundary of the outer enclosure. Approximately midway along its length a $c 2 \mathrm{~m}$ long spur projected southwards. Approximately $14 \mathrm{~m}$ further east, a $c 3 \mathrm{~m}$ length of a similar feature was present $c 1.5 \mathrm{~m}$ outside the outer enclosure boundary. These remains defy any convincing interpretation, although their alignments do suggest that they were in some way related to the outer enclosure, either as parts of a precursor boundary or as components of related external works - the former interpretation was proposed in the interim account (Triscott 1982, 119). There is no reason to believe that they represent the denuded remains of the formerly continuous outer element of a double palisade structure.

At the very northern end of the site a linear feature, $c 0.3 \mathrm{~m}$ wide and on a north-west/south-east alignment, projected into the trench for $c 6 \mathrm{~m}$, terminating $c 10 \mathrm{~m}$ from the outer enclosure. It had a silty fill and nowhere survived greater than $0.1 \mathrm{~m}$ deep. A post-hole or pit close to its terminal may have been a related feature. The interpretation of this partially exposed feature is a matter of conjecture, although it might be related to a paddock or field associated with the outer enclosure. 


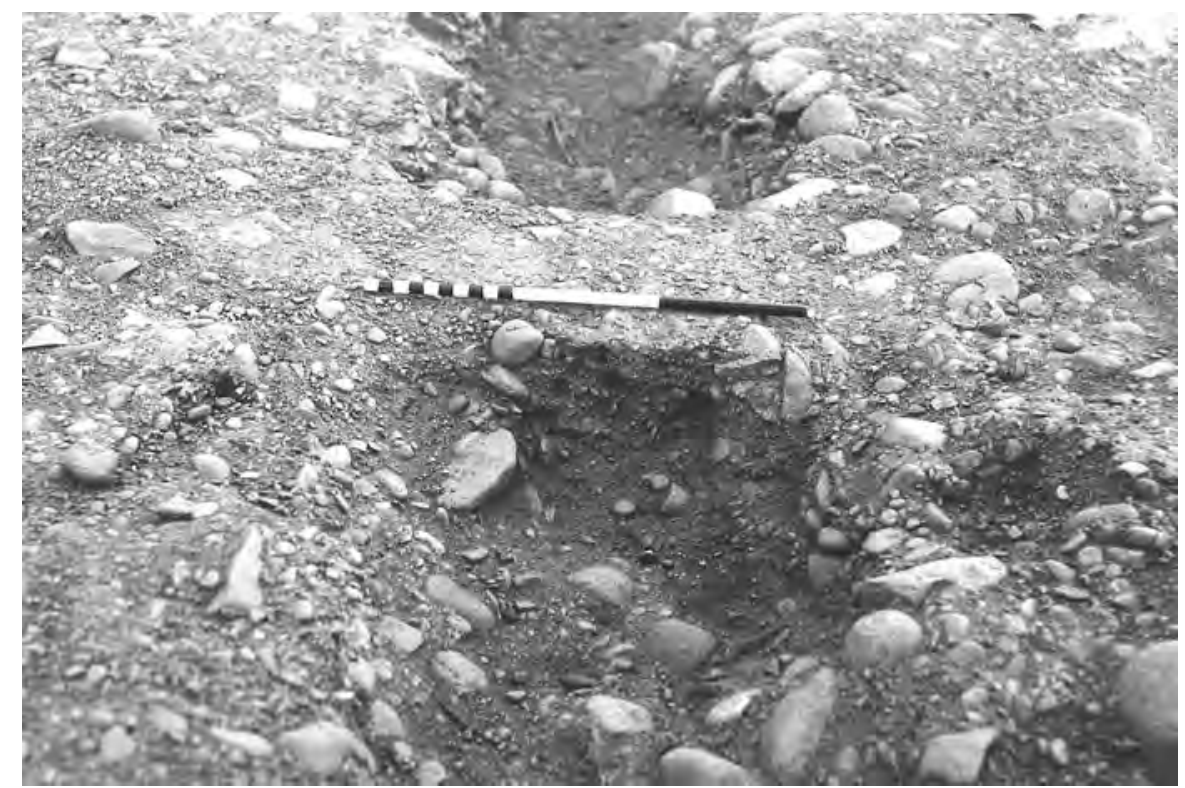

Illus 20 Inner enclosure; sample section of palisade trench

\subsubsection{Inner enclosure (illus 3; illus 20)}

Topsoil removal revealed the presence of a subrounded enclosure occupying the north-east interior of the outer enclosure. This inner enclosure measured $c 32 \mathrm{~m}$ north-west/south-east by $c 30$ $\mathrm{m}$. To the north-east the boundary of the inner enclosure was congruent with that of the outer enclosure for a length of $c 12 \mathrm{~m}$ (illus 3 ). Elsewhere, the smaller enclosure was bounded by a foundation trench which was generally less well-preserved than that defining the larger enclosure. To the south and west the trench was $c 0.2 \mathrm{~m}$ wide by up to $0.25 \mathrm{~m}$ deep, whereas to the north its discontinuous remains were very shallow or had been entirely truncated by ploughing. It contained noticeably less evidence of stone-packing than the palisade trench of the outer enclosure, suggesting a construction technique different to that implied by the surviving foundation of the larger enclosure. What stone-packing was present did not appear to remain in situ and post-sockets could not be readily established. Otherwise the fill was mostly featureless, containing few stones and pebbles (illus 20). There was no evidence to suggest repair or re-cutting of this foundation trench.

The inner enclosure had a single entrance $c 1.7 \mathrm{~m}$ wide on its east side, flanked on either side by a post-hole set within the palisade trench terminals (illus 17; illus 18). It lay $c 2 \mathrm{~m}$ inside the north-east entrance of the outer enclosure, and was offset slightly to the north of it.

Fragments of cattle and sheep tooth fragments were recovered from the fill of the inner enclosure palisade trench, as well as a stone with a ground depression (Cat no 46), and two plain body sherds of pottery (Cat nos 27-28).

\subsubsection{Relationship between the two enclosing works}

The chronological relationship between the two enclosures could not be resolved through establishing stratigraphic relationships at their points of intersection. The northern intersection point did not survive as the inner enclosure had been completely plough-truncated at this point, whereas the excavation at the eastern intersection revealed no meaningful information.

Despite this lack of evidence for sequence, it is apparent from plan evidence that the use of the two enclosures overlapped and at some stage both were standing. The coincidence of the two enclosure alignments strongly suggests this, but more conclusive information comes from the adjacent entrances (illus 17; illus 18). Here, the offset entrances created an entrance passage running obliquely to the alignments of the enclosure boundaries. A cluster of post-holes and pits was present along this passage area, from one of which a sherd of coarse later prehistoric pottery was recovered (Cat no 30). Some of these features may define the foundations of a passage or even gate structure passing between the two enclosure works, whereas others lay within the centre of the passage and may contrastingly be the foundations of blocking features. To the south of the entrance passage, and between the enclosing works, a linear group of pits can be interpreted as the foundations of a feature blocking access from the entrance passage to the main body of the outer enclosure (or vice versa). The very fact that this latter group of features runs between the two enclosures lines would appear to presuppose that they co-existed.

The chronological relationship between the two enclosures is discussed further in Section 7.2.2, as 


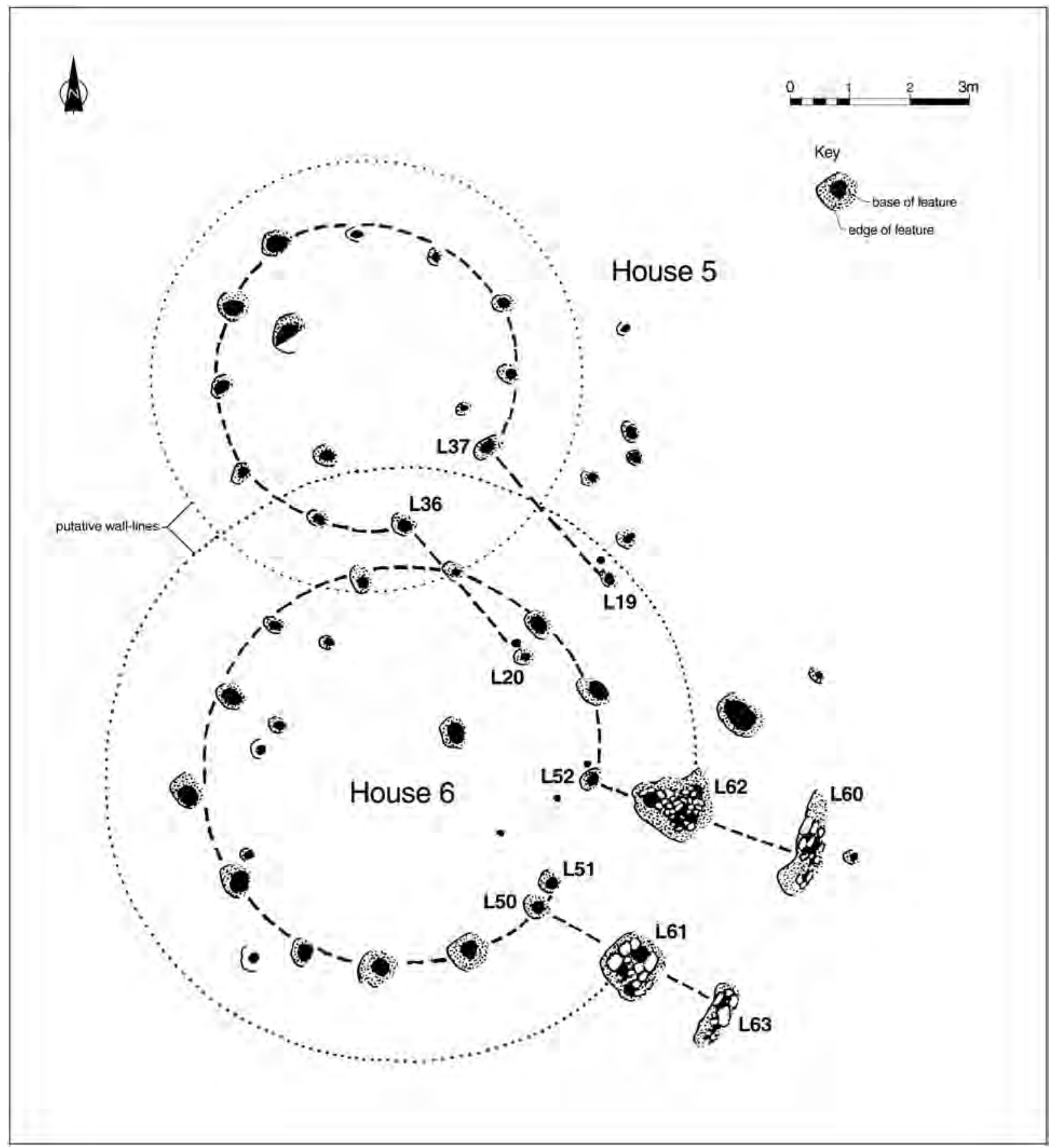

Illus 21 Plan of Houses 5 and 6

the relative alignments of the entrances to House 1 and the enclosures provide important circumstantial evidence in that regard.

\subsection{Post-ring buildings}

\subsubsection{Houses 5 and 6 (illus 21; illus 22; illus 23)}

Description Two adjacent post-ring structures were present towards the centre of the outer enclosure. They are considered together as their juxtaposition requires explanation in terms of their structural, functional and chronological relationships, in as much as this is possible given the heavily denuded character of the surviving remains.

House 5 comprised a ring of 11 post-settings, spaced at $0.8-$ to $1.2-\mathrm{m}$ intervals, and defining an internal space with a diameter of $c 5.2 \mathrm{~m}$ (illus 22 ). The post-pits varied in diameter between $0.2 \mathrm{~m}$ and $0.6 \mathrm{~m}$ and in depth between $0.05 \mathrm{~m}$ and $0.3 \mathrm{~m}$ (but mostly $0.1-0.15 \mathrm{~m}$ ). Some post-pits contained stone packing, in some cases largely intact and in others disturbed. While this evidence might indicate that the pits held posts of variable size, it is more likely that the observed pattern reflects 


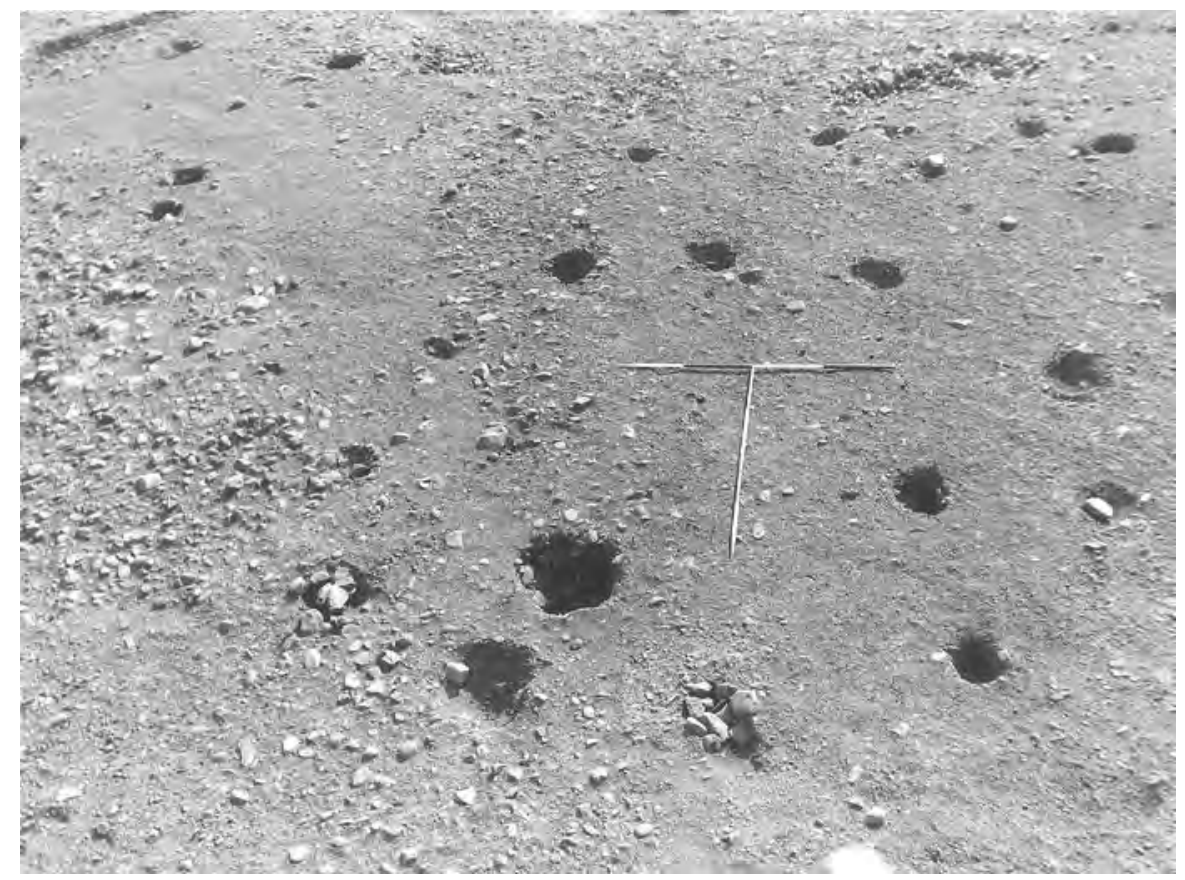

Illus 22 House 5 photograph from the west

primarily differential preservation. Three pits were identified towards the periphery of the floor space within the post-ring.

The entrance to House 5 is most probably defined by a $c 1.6 \mathrm{~m}$ wide gap between posts L36 and L37 on the SSE side of the building. The site records contain a suggestion that posts L19 and L20 may define the outer end of an entrance passage $c 3 \mathrm{~m}$ long. If accepted, this feature would have important implications for assessing the relationships between Houses 5 and 6 (see further below).

House 6 was slightly larger, comprising a ring of 13 posts, also spaced at $0.8-1.2 \mathrm{~m}$ intervals, which defined an internal space of $6.8 \mathrm{~m}$ diameter (illus 23). The character and dimensions of the post-pits were comparable to those of House 5. The floor space within the post-ring contained a few pits, which formed no discernible pattern and contained no indication as to their function.

The entrance to this roundhouse was to the southeast. It was defined within the post-ring by a $c 2 \mathrm{~m}$ gap between posts L50 and L52. A post-setting present within the entrance area (L51) may have been a door-post foundation. These features formed the inner end of an elaborate entrance structure projecting south-east of the building, formed by two opposing pairs of complex post-pits. The inner pair (L61, L62) were each sub-rectangular pits over $1 \mathrm{~m}$ across, containing three stone-packed post-settings. The posts appeared to have been substantial, for example the northernmost upright in L61 measured $0.4 \mathrm{~m}$ by $0.3 \mathrm{~m}$ in cross-section and survived to a depth of $0.4 \mathrm{~m}$ (considerably deeper than were all the components of the post-ring). The outer pair (L60, L63) were more linear in form, the northern $c 2 \mathrm{~m}$ long and $0.6 \mathrm{~m}$ wide, each containing a stonepacked post-setting.

No artefacts or ecofacts were recovered from either building, and no material suitable for radiocarbon dating was identified. Neither house contained any evidence of replacement or refurbishment.

Reconstruction While Houses 5 and 6 do not have any stratigraphic links with any other element of the site, their inter-relationship is of considerable importance. Given their broadly similar size and structural form (apart from at their entrances), and their juxtaposition, it is worth considering whether the two post-rings could represent elements of a single roofed figure-of-eight building. Buildings of this basic form are rare but not unknown within the later prehistoric settlement record in northern Britain, an example including the stone-walled structure at Ceann nan Clachan (Armit \& Braby 2002). Conjoined but independently entered 'tangential' hut circles have also been recorded in upland Perthshire (Harris 1984).

The surviving evidence from Houses 5 and 6, however, argues strongly against such a reconstruction. Firstly, the lack of alignment between the post-rings where they are almost tangential demonstrates effectively that there was no connecting passage between the two floor spaces. Secondly, both structures were provided with independent entrances on differing alignments.

If it is accepted that House 5 possessed a projecting entrance structure defined by posts L19 and L20, then this feature would have projected through the post-ring alignment of House 6, effectively demonstrating the non-contemporaneity of 


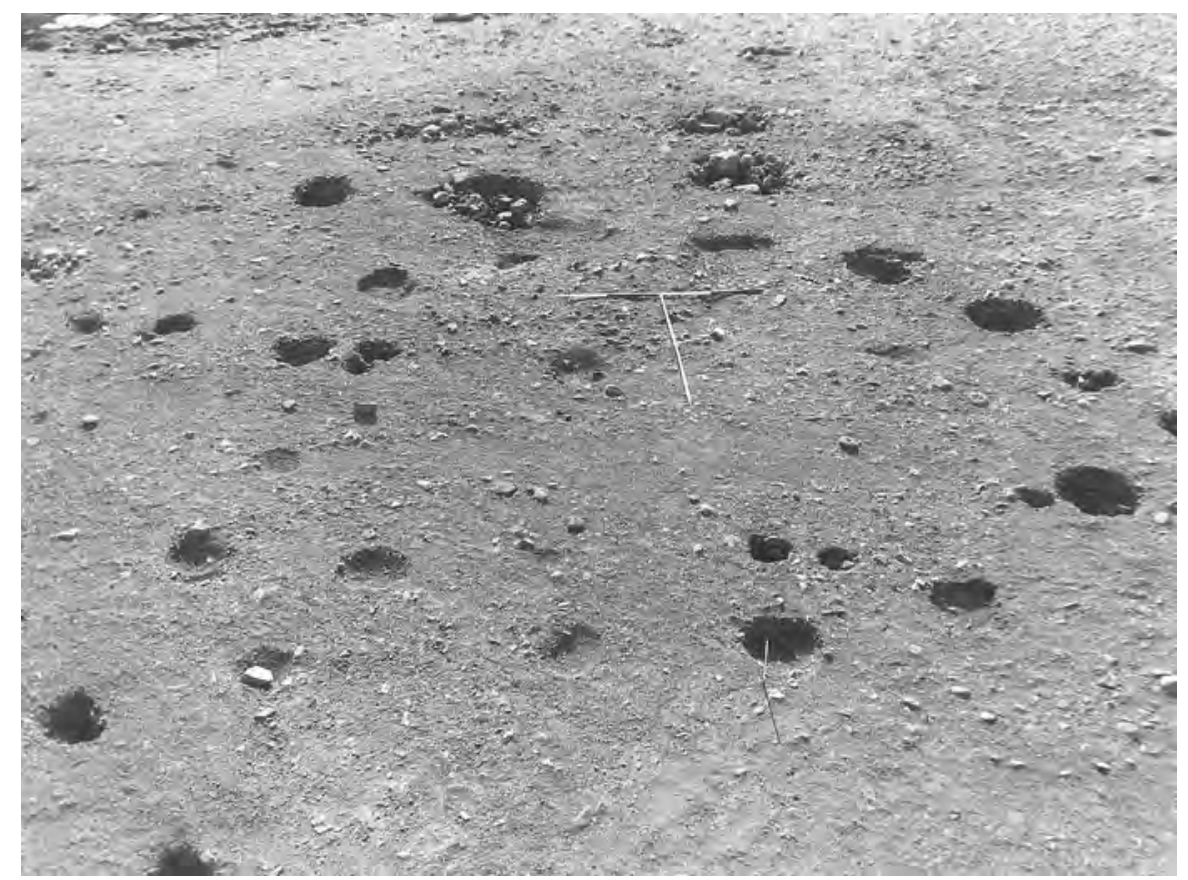

Illus 23 House 6 photograph from the north-west looking along the entrance passage in the background

the two structures. However, the evidence for this proposed entrance passage is less than conclusive. When compared to other post-ring roundhouses at Dryburn Bridge with more convincing evidence for entrance structures, the absence of intermediate foundation features between the four corner posts is noticeable. In addition, the slightness of the proposed foundations contrasts sharply with the scale of those surviving at House 6.

With the acceptance that Houses 5 and 6 form separate buildings, their reconstructed forms can be considered. The post-rings presumably formed roof support frameworks within the floor space of the building. The positions of the walls do not survive, and these may have been of turf or stone, all traces of which have been removed by ploughing. Using Hill's proposed ratio of 1:0.707 to determine the relative radii of post-rings and former walls within timber roundhouses (Hill 1984), diameters of $c 7.4 \mathrm{~m}$ and $9.6 \mathrm{~m}$ can be estimated for Houses 5 and 6 , respectively (the presumed wall lines based on this ratio are depicted on illus 21). The near-absence of other archaeological features within the zones between post-rings and presumed wall-lines of the buildings is noteworthy and may reflect variations in the spatial patterning of activities that took place within the buildings.

For House 6, the presumed wall alignment based on Hill's ratio coincides with the post-pits L61 and L62, suggesting that this building was provided with a projecting entrance structure $c 1.5 \mathrm{~m}$ long, its outer end defined by post-pits L60 and L63. The posts forming this structure were large in size, which tends to suggest that they were intended to bear the weight of a special feature, such as a porch. The three post-settings within each post-pit at the inner end of the porch could relate variously to the wall-ends, porch framework and a separate door-frame (cf Guilbert 1976, 308). As is routinely applied as a caveat to the interpretation of function of timber roundhouses, there is nothing in the excavated evidence of these structures to suggest directly whether they were used as domestic residences or otherwise (cf Dunwell 1999, 348-50) and the former interpretation is often accepted faute de mieux.

By contrast, there are no surviving archaeological remains to suggest that the predicted wall line of House 5, applying Hill's ratio, is accurate. Barclay has discussed how not all excavated building dimensions, where both post-ring and wall alignments are known, conform to this ratio (Barclay 1993, 265-6), and indeed some vary considerably from it - for example, House 1 at Dryburn Bridge (Section 7.2.2) has a ratio of 0.652 . The possibility that posts L19 and L20 define the wall alignment is worth considering. This would indicate a ratio of 1:0.47 and an overall building diameter of $c 11.4 \mathrm{~m}$. While structures displaying this sort of ratio are not unknown (Barclay 1993), they are uncommon, and to propose it for House 5 would be to stretch the evidence considerably. L19 and L20 may in fact not be part of an entrance structure at all; they could alternatively form part of a curving line of pits running to the east of House 5 (illus 3).

Stratigraphic and spatial relationships Given that the two buildings occupied the same space and thus could not have been contemporary, in which order were they constructed? There are no physical stratigraphic relationships to rely on, and thus the evidence is circumstantial and relates to 
the significant spatial relationships of House 6. If the $c 2 \mathrm{~m}$ wide axis of the entrance to House 6 is projected south-east (illus 3), it is striking that the approach is lined on its south side by rectangular structures A-C and Burial 12 (Section 7.5; Section 7.6). Occasional pits are also present that might define the north side of this passage, although these lie within the outer wall-line of Structure 2 and could also relate to that building. The projected approach alignment intersects the outer enclosure at precisely that point on its east side where the excavators suspected, but could not conclusively demonstrate, the presence of a central entrance. Thus it is possible to envisage that the entrance to House 6 would have been visible directly ahead, to those entering the palisaded enclosure through any former (but unproven) entrance at that location. This arrangement is paralleled in the relationship between House 1 and the north-east entrance to the outer enclosure (Section 7.2.2). It is thus possible to extrapolate, on the basis of the weight of this circumstantial evidence, that House 6 was integral to the original design of the outer enclosure, as was House 1 .

This observation says nothing directly about the chronological relationship between Houses 5 and 6 . Whether one structure was a direct replacement of the other, as opposed to a significantly later construction, is not demonstrable. However, the lack of alignment between the entrances of Houses 5 and 6 is surely significant, reflecting different design considerations or changed site organization. These issues, which relate to overall site development, are further addressed in Section 11, as are the implications of the observation that the proposed approach to House 6 is cut by House 2. As there is no stratigraphic evidence for any other settlement features pre-dating the outer enclosure, it is the author's opinion that House 6 preceded House 5, although ultimately this conclusion is assertion rather than based upon empirical evidence.

\subsubsection{House 1 (illus 24; illus 25; illus 26)}

Description The surviving remains of House 1 can be grouped into four elements: an inner postring, which may demonstrate rebuilding; an outer post-ring; an elaborate entrance structure; and a scattering of internal features. Some of the features on the west side of the building may be components of House 4 (Section 7.2.3), although it is difficult to determine which ones. The northern side of the building survived less well than the southern, and appears to have been subject to greater ploughtruncation. The western interior was largely devoid of archaeological features, in contrast to the dense scatter to the east. It is apparent that the area with few features corresponds to a band of fine gravel and sand subsoil, whereas the denser spread of features were cut into a coarser cobble and pebble subsoil (illus 25). While it is possible that the observed distribution of features represents real patterning of activity within House 1, it more likely reflects variable preservation of the remains, with the softer, sandy subsoil areas more susceptible to biting and disturbance from the plough.

The inner post-ring was defined by at least 15 postsettings, generally spaced around $1.2 \mathrm{~m}$ apart, but with intervals decreasing to $0.8 \mathrm{~m}$ and increasing to $1.6 \mathrm{~m}$. These generally survived in the order of $0.5 \mathrm{~m}$ wide and $0.2 \mathrm{~m}$ deep. The posts define a space $9.4 \mathrm{~m}$ in diameter. A $2 \mathrm{~m}$ wide gap on the south-east side of the post-ring defines the alignment of the entrance passage. There are reasonable grounds for proposing that at some stage during the life of the building the inner post-ring was replaced by a secondary, more ovate, post-ring bounding a smaller space. An arc of five post-holes set at $1-1.4 \mathrm{~m}$ intervals was traced diverging from the southern side of the inner postring, suggesting that the original two post positions on the south-east side of the entrance passage may have been reused. To the north-east, at least three of the pits of the inner post-ring are accompanied on their south-west side by neighbouring post-settings that could also relate to the proposed replacement ring. This north-east arc may also have branched from the alignment of the original inner post-ring, reusing the two post positions on the north-east side of the entrance passage. The absence of connecting features between these two arcs is probably a facet of archaeological survival, as the intervening space is occupied by the softer subsoil. It is estimated that the refurbished inner post-ring defined an area of $c 8.7 \mathrm{~m}$ north-east/south-west by $7.3 \mathrm{~m}$ north-west/south-east.

The outer post-ring was only apparent in a coherent manner on its southern side, although the much truncated remains of at least two post-holes are preserved to the north. Those that do survive are spaced at $c 1.6-2.4 \mathrm{~m}$ intervals, defining an internal space with a diameter of $c 14.4 \mathrm{~m}$. They appear to have been paired approximately with settings of the inner post-ring, such that the post pairs for the most part lie approximately along alignments radiating from the centre of the building (defined on illus 25 by feature B71). Thus, for geometric reasons alone, it is reasonable to conclude that the inner and outer post-rings form part of a single design. It is perhaps significant that the posts of the outer ring and the replacement inner ring do not consistently form the same radial alignments. A $2 \mathrm{~m}$ wide entrance passage was present to the south-east, in alignment with the gap in the inner post-ring.

The entrance passage to House 1 was of complex form, being $c 5 \mathrm{~m}$ long and $2 \mathrm{~m}$ wide. Its inner end was defined by the inner post-ring, the terminal posts of which were no larger than other settings of that post-ring. The same is the case for the outer post-ring. However, between the two rings much more substantial post-pits were present, containing large stone-packed post-sockets preserved to $0.5 \mathrm{~m}$ deep (over twice as deep as the surviving foundations of the post-rings). These substantial posts were 


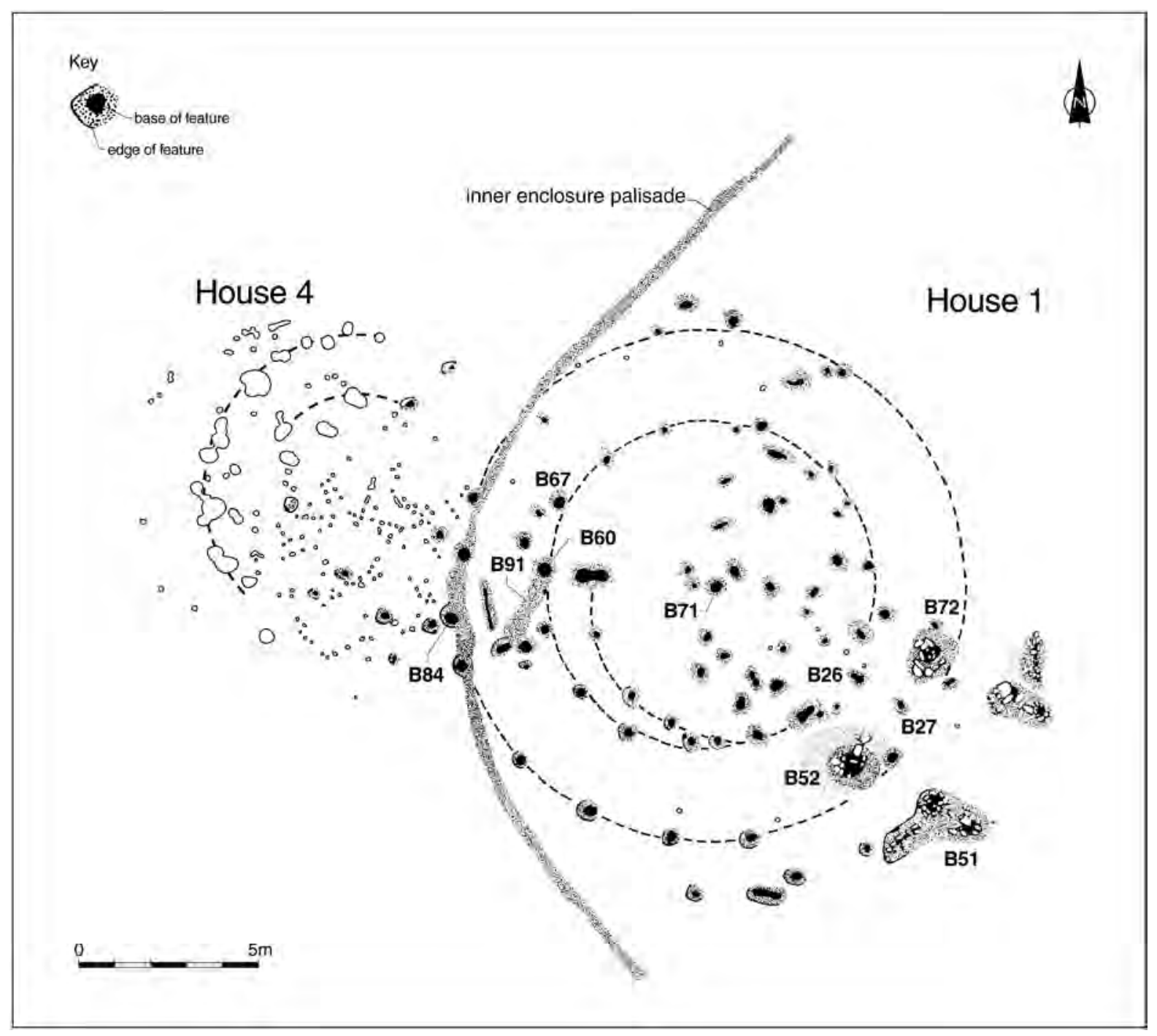

Illus 24 Plan of Houses 1 and 4

intended to bear a heavy load. Outside the outer post-ring were complex L-shaped post-pits to either side of the entrance passage, each containing two substantial stone-packed posts lining the entrance passage and stone-packed foundations slots running away perpendicularly from the entrance passage for c 1.5m. Posts B26 and B27 (illus 24; illus 25) are of particular interest in that they lay centrally within the entrance passage. They may have formed the foundations for a screen dividing the passage longitudinally into two separate corridors running between the two post-rings. They could have defined the positions of double doors running across the passage, although this explanation is not preferred as it seems more likely that any doors would have been hung off the terminals of the post-rings. The overall morphology of the entrance structure in ground plan is strikingly similar to that of House 6 .

The majority of internal features clustered in the eastern half of the building, within the inner postring although, as noted above, this may be a survival bias. A number of these features were post-holes of character and dimensions comparable to those in the post-rings. A stone-packed post-pit (B71) was present at the very centre of House 1 . While this feature could be interpreted as the foundation for a central roof support, the strength of the surrounding earthfast timber framework would certainly not have required an additional prop at this point. This central feature could alternatively be conceived as part of a support framework for an upper floor within House 1, along with other internal postholes. It is perhaps significant that the foundations of the proposed dividing screen within the entrance passage align with the central post-pit.

The floor space between the two post-rings was largely devoid of archaeological features, apart from to the west where two shallow linear hollows and adjacent post-pits were clustered (illus 26). One of these linear hollows appeared to incorporate one of the inner post-ring settings (B60). The functions of these features are not known. 


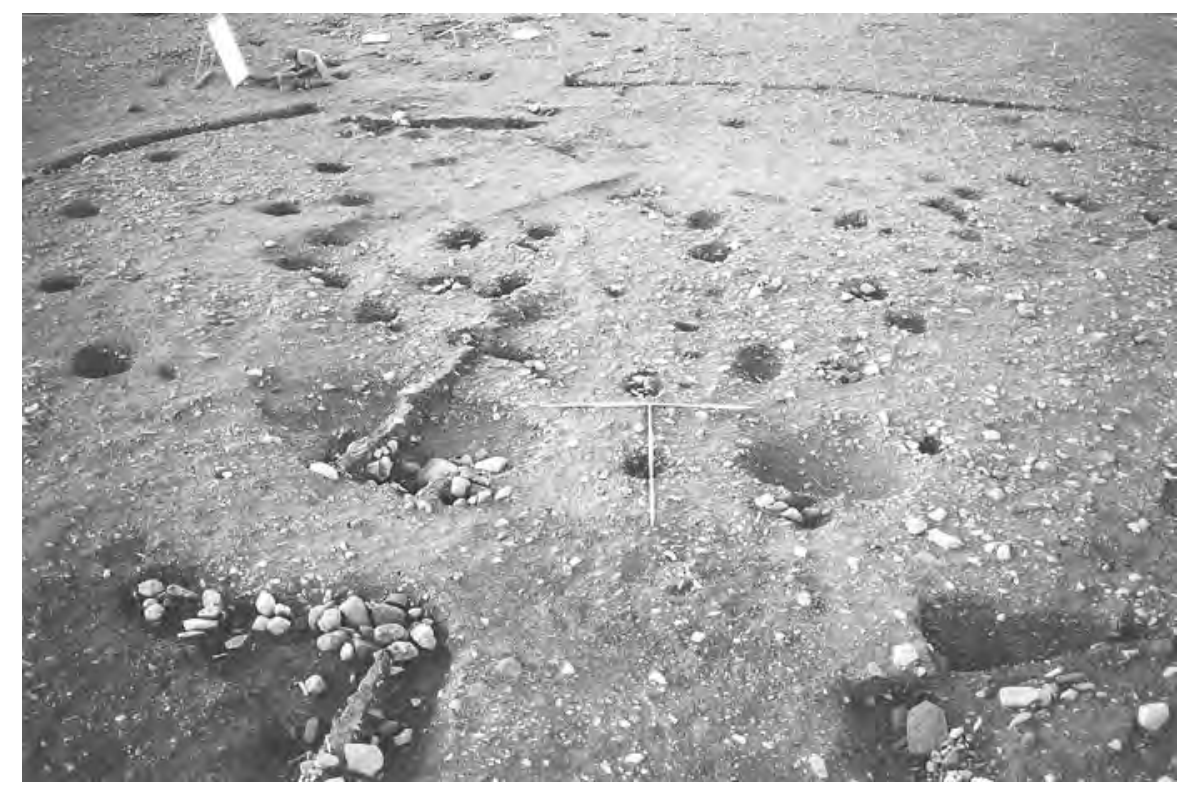

Illus 25 House 1; from south-east looking along its entrance passage with the inner enclosure boundary in the background

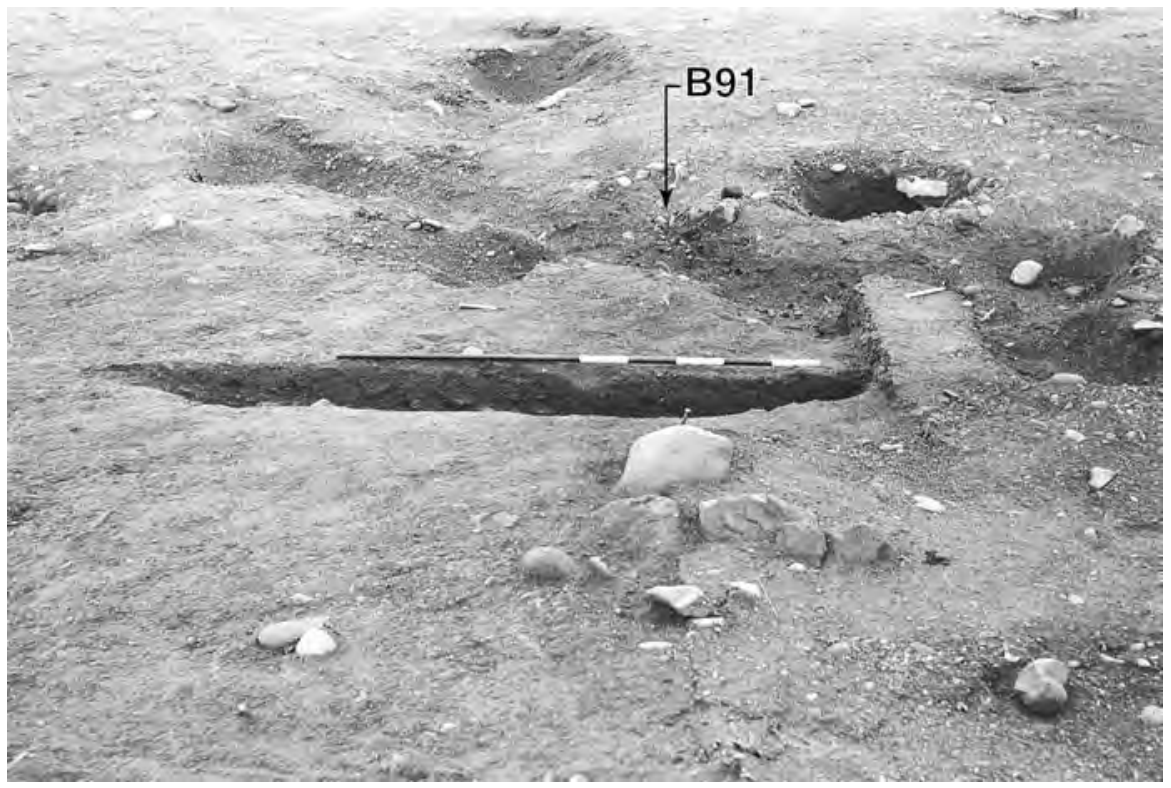

Illus 26 Linear features on the west side of House 1; and post B84. Feature B91 is visible fully excavated behind the scale bar

Finds recovered from House 1 were limited to an iron ring (Cat no 160, illus 61) and bone fragments found in dark loam above the packing of central post B71; pottery from one of the post-pits of the outer post-ring (B67, Cat no 41); and chipped stone and bone fragments from certain entrance post-pits (B51, B52). Nothing suitable for radiocarbon dating was recovered.

Reconstruction The interim report (Triscott 1982, 119-20) proposed a reconstruction of House 1 as a massive building $18 \mathrm{~m}$ in overall diameter, with two internal roof support post-rings and an outer wall, which did not survive, running concentrically outside them, its alignment indicated by the posts and slots defining the outer end of the entrance passage. Under this reconstruction the building possessed an internal lobby or corridor rather than an external porch (for a similar interpretation see Avery \& Close-Brooks 1969, on the Shearplace Hill roundhouse). Triscott drew parallels between House 1 and those at West Brandon (Jobey 1962), West Plean (Steer 1956) and Braidwood (Piggott 1958).

While such a reconstruction cannot be ruled out, not least because timber-framed roundhouses approaching $20 \mathrm{~m}$ in diameter are not unknown 
in south and east Scotland (reviewed by Hingley 1992, 27-9), there are good grounds for interpreting House 1 as a somewhat more modest, although still imposing, building. Comparison between House 1 and House 6 is instructive in this regard, as the two roundhouses have closely comparable entrance structure ground plans. Because House 6 has only a single post-ring, the outer two pairs of entrance foundations cannot both relate to wall-lines, and hence it has been posited that this building was provided with an elaborate projecting porch. The same logic can be applied to House 1, in which the outer post-ring represents the wall-line and the outermost entrance features are part of a similarly elaborate and substantial projecting porch. The linear slots present at the outer end of the entrance passage could have been the foundation for some form of elaborate façade visible to those approaching the building. In both cases, of course, depending upon the height of the wall and the pitch of the roof, the overall diameters of the buildings could have been more imposing.

Control of access arrangements appears to have formed an important consideration in the design of House 1. Once through the external porch, it appears that the passage between the two post-rings was divided into two. One can speculate almost endlessly as to potential explanations for this feature, ranging from functional explanations concerned with the control of circulating draughts; through structuralist-based social explanations such as the provision of a male and a female entrance; to cosmological explanations such as the provision of an entrance passage along the south passage, allowing for sunwise circulation around the building leading to an exit along the north passage (cf Fitzpatrick 1997; Parker Pearson 1999a). No additional evidence could be adduced in support of any of these propositions. It is hoped that the evidence from House 1 will contribute to wider studies of the organization of space and activities within later prehistoric roundhouses.

Within the building it is possible that the central area, within the inner post-ring, was used differently from the peripheral area between the inner post-ring and wall-line. The two could have been separated by screening or walling hung off the frame of the inner post-ring. There is good evidence for believing that the building was provided with an upper storey (as reconstructed by eg Reynolds 1982,51-3; and see Armit 1997, 33 for a ring-ditch house).

Stratigraphic and spatial relationships The reconstructed form of House 1 overlaps with the alignment of the inner enclosure boundary, and it is apparent (illus 24) that the two could not have formed contemporary elements of the settlement layout. The stratigraphic evidence is typically ambiguous in this regard, relying upon the relationship between three post-holes strung along the enclosure boundary line. Of these, B84 was inserted through the palisade, and therefore was secondary to it (it is shown prior to excavation in the foreground on illus 26). However, this feature does not appear to have formed part of the wall-line of House 1, as its position on the circuit of the outer post-ring was not matched by a corresponding post on the inner postring, and did not necessarily relate to that building at all. The excavated evidence from the other two post-holes, which probably did form components of the House 1 wall-line as they were in positions matched by post-settings on the inner post-ring, was not instructive as to sequence. This is inconvenient as it does not allow any conclusions to be based on stratigraphic evidence.

However, a good case can be made for the primacy of House 1, based upon evidence of spacing. The entrance to House 1 aligns with the north-east entrance of the outer enclosure, and it seems highly probable that the two were linked as part of a single deliberate scheme, forming part of the original design of the outer enclosure. A similar relationship has been posited above between House 6 and the suspected blocked middle entrance to the outer enclosure.

As discussed in Section 7.1.4, it is apparent from the excavated evidence of their adjacent entrances that the outer and inner enclosures must have coexisted. Because the inner enclosure boundary cut across the direct alignment between the outer enclosure entrance and the entrance to House 1 (illus 3), it is reasonable to propose that the inner enclosure was a secondary construction inserted into the outer enclosure following the demolition of House 1. It is not possible to construct a sustainable sequence in which the inner enclosure was primary and the clearly linked construction of House 1 and the outer enclosure were secondary, as the outer enclosure would require the continued presence of the inner enclosure (based upon the entrance morphology detailed in Section 7.1.4) and House 1 would require the inner enclosure to have been demolished (based upon the linked entrance alignments of House 1 and the outer enclosure)! This reconstructed sequence has important implications for understanding the phasing of the site as a whole. The proposal of a secondary origin for the inner enclosure revises the interpretation of this feature as a pre-settlement element proposed in the interim report (Triscott 1982, 119).

\subsubsection{House 4 (illus 24; illus 27; illus 28)}

Description A cluster of post-holes to the west of House 1 appears to represent the remains of another building. The most coherent structural evidence is provided by an arc of at least 12 post-holes, for the most part spaced less than $0.6 \mathrm{~m}$ apart and surviving to less than $0.2 \mathrm{~m}$ deep (illus 24; illus 28). Extrapolation of this arc to form a circle would indicate a ring with a diameter of $c 9 \mathrm{~m}$, overlapping with House 1 and the inner enclosure boundary to the east. Within the area defined by this arc are several other post-settings and pits, of which three can be linked 


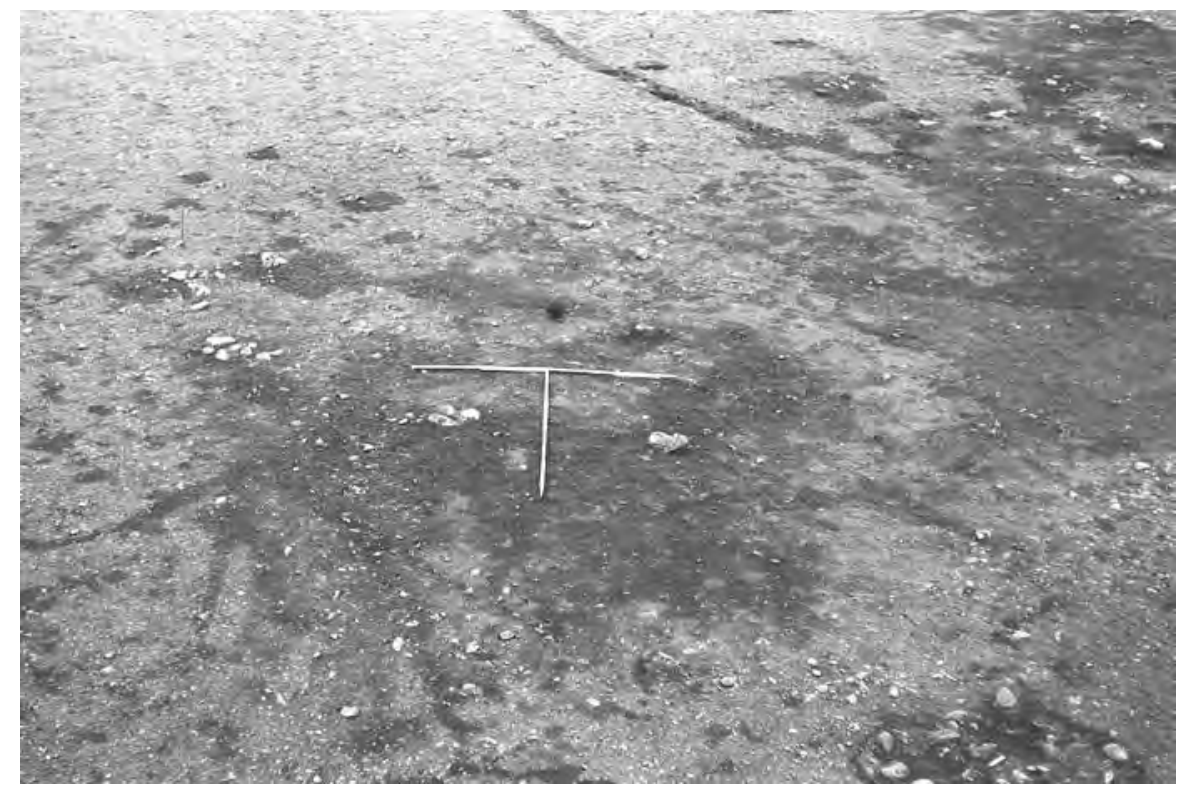

Illus 27 House 4 as first revealed; from the south-west

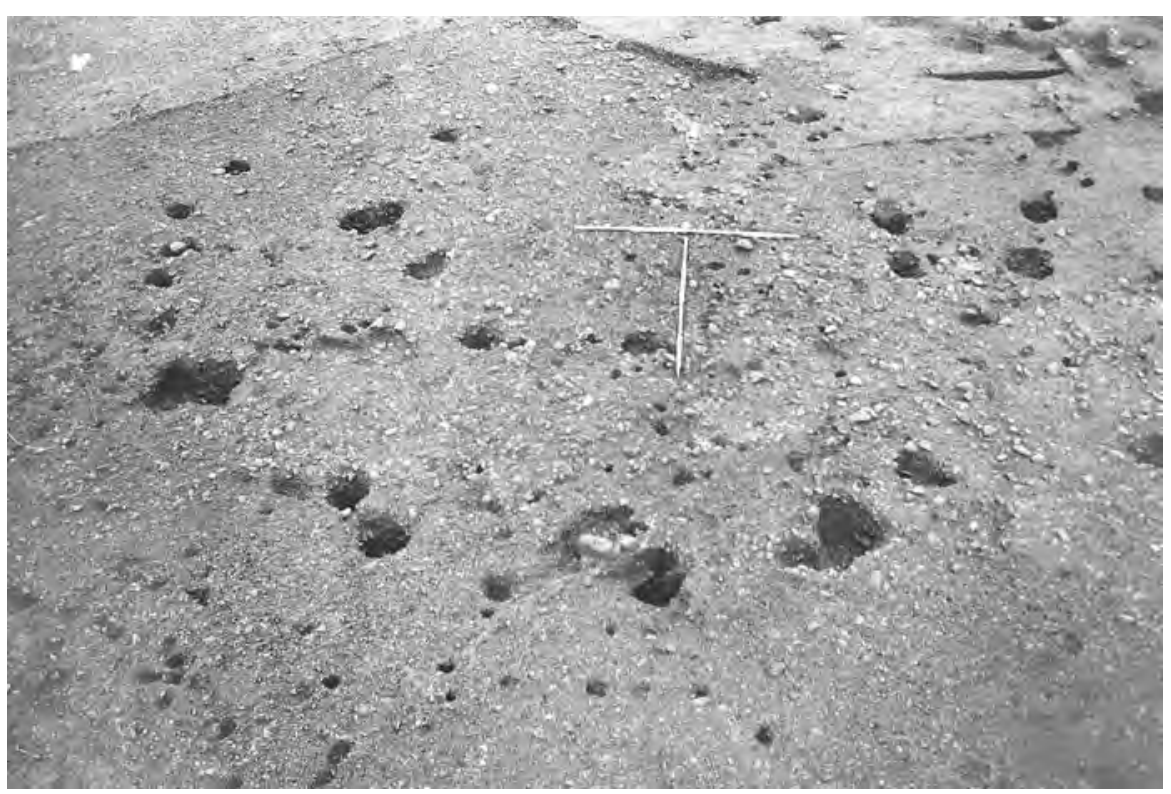

Illus 28 House 4 as excavated; from the south-west

to form an arc running parallel with the outer arc. A dense cluster of stake-holes was present in the same area, but these also extend west of the posthole arc (in the foreground on illus 27 and illus 28). The only artefacts recovered were flint chips from the basal topsoil overlying the remains (shown on illus 27). Nothing suitable for radiocarbon dating was recovered.

Reconstruction While it is theoretically possible to extrapolate the identified post-hole arcs to propose a double-ring roundhouse with a diameter of $9 \mathrm{~m}$, such a reconstruction does not bear close scrutiny. The principal objection lies in the lack of surviving evidence for the eastern side of such a building, for which no particular taphonomic considerations can be brought to bear. Post-settings were recorded in that area, which did not relate to House 1, and which thus may have belonged to House 4, but these still do not allow a coherent structural plan to be reconstructed.

Moreover, the post-settings are much more closely spaced than those forming the post-rings of other roundhouses excavated at this site. This probably indicates that House 4 was a type of construction different from the timber-built roundhouses elsewhere on the site, and could have been of less substantial build. With this in mind, there is no 
reason to believe that the construction represented by these remains was circular, or even of comparable date to the other structures. Perhaps the building was no more than a windbreak or temporary shelter. As noted previously, given the proximity of the Late Neolithic/Early Bronze Age burial cists, as well as a cluster of pits containing Late Neolithic pottery, the remains described as House 4 may have been of similar date.

The alignments of stake-holes surviving in sand in this area need not belong to the postulated structure. Stake-holes were not recorded in such densities anywhere else across the excavated area. Their relative isolation in the same part of the site as the Late Neolithic/Early Bronze Age burial cists may be significant, but any association is beyond proof.

\section{Stratigraphic and spatial relationships Given} the uncertainties regarding the reconstruction of this feature, it is not possible to make any meaningful statements in this regard. None of the components of the post-hole arcs have any stratigraphic relationships with any other surviving elements of the site. Given the significant differences in structural form there is no reason to regard Houses 1 and 4 as components of a single conjoined structure, and they may indeed have been very different in date.

\subsubsection{House 10? (illus 3; illus 29)}

Description The excavators identified nine roundhouses during the excavations at Dryburn Bridge (Houses 1-9). However, examination of the site records by the author revealed what may be the remains of a tenth structure, a post-ring roundhouse, occupying the central southern interior of the outer enclosure (illus 3 ; illus 29). The presence of such a structure cannot be regarded as certain, because it was not recognized during the excavations and has been distinguished from the site records by a third party. However, what evidence has been garnered in support of the interpretation suggests to the author that a building is likely to have been present.

The putative structure is defined by a single post-ring of what appears to be at least 14 postsettings that define an area of $c 8.2 \mathrm{~m}$ in diameter. The southern side of the post-ring is more readily detectable, being defined by an arc of six large features (between $\mathrm{O} 65$ and 098), equally-spaced c $1.5 \mathrm{~m}$ apart, most of which are described in the site records as packed post-holes $0.25-0.3 \mathrm{~m}$ deep (the packing disturbed). The north side of the building may be defined by smaller post-settings, also spaced at $c$ 1.5-m intervals, although with one exception (O73), which was $0.25 \mathrm{~m}$ deep, it was not possible to establish the depths of these features from the site records. Based upon these intervals, a post position would have been expected in the area of the postring occupied by curvilinear ditch O76 (Section 7.8.4). Two of the northern posts lay adjacent to or abutted posts forming part of rectangular structure $\mathrm{H}$ (Section 7.5). At least two of the posts on the north side of the putative structure consisted of two adjacent post-holes, possibly suggesting at least localized refurbishment of the putative structure.

The entrance to the putative structure is defined by a $c 2 \mathrm{~m}$ wide gap on the south-east side of the building, between post-settings $\mathrm{O} 73$ and $\mathrm{O} 65$. Post-pit 052, which survived $0.6 \mathrm{~m}$ deep, and posthole 054 may define the northern side of a porch structure comparable to those identified for Houses 1 and 6 . Certainly the plan view morphologies of the two pits are comparable respective features forming components of the entrances to those other structures, including what appears to have been a linear slot extending from the outermost post. Post-pit O49 may have formed part of the southern side of the entrance structure, although the outermost postsetting on that side is not evident, its likely position occupied by a large pit (O48).

Reconstruction Based upon what can be gleaned from the excavation records, it is possible to propose that the central southern interior was occupied by a post-ring roundhouse of similar character to Houses 1 and 6 , although with a floor area intermediate in size between those others. The putative structure had a diameter within its single post-ring of $c 8 \mathrm{~m}$. Application of Hill's ratio (Hill 1984) suggests that the wall-line, of which no archaeological trace can be distinguished, may have been on an alignment that defined an area $c 11.3 \mathrm{~m}$ in diameter. However, if the wall had aligned on the putative entrance post-pits $(\mathrm{O} 49, \mathrm{O} 52)$, as was probably the case for House 6, then a larger diameter in the order of $c 12.5 \mathrm{~m}$ could be anticipated.

The putative structure had a south-east-facing entrance provided with an external porch comparable in terms of ground plan morphology to those that characterize Houses 1 and 6 . The axis of the entrance is aligned closely on the south-east entrance to the outer enclosure (illus 3).

Stratigraphic and spatial relationships There are several archaeological features present within the floor area of putative House 10. Some of these could have been internal features of the building, although this is beyond proof, whereas others could not have co-existed with the putative roundhouse (illus 29). Feature O76 (Section 7.8.4) runs across the interior of the putative roundhouse, and if open during the lifetime of the roundhouse would have blocked direct access between its entrance and the rear of the building. It also runs across the north side of the post-ring alignment at the point where a post-hole could be expected to survive on grounds of spacing, but did not. It is suspected, therefore, that feature O76 was secondary to the putative House 10 , and was excavated following the removal of the roundhouse. The floor areas of putative House 10 and rectangular structure $\mathrm{H}$ (Section 7.5) overlapped, although examination of the site records provided no 


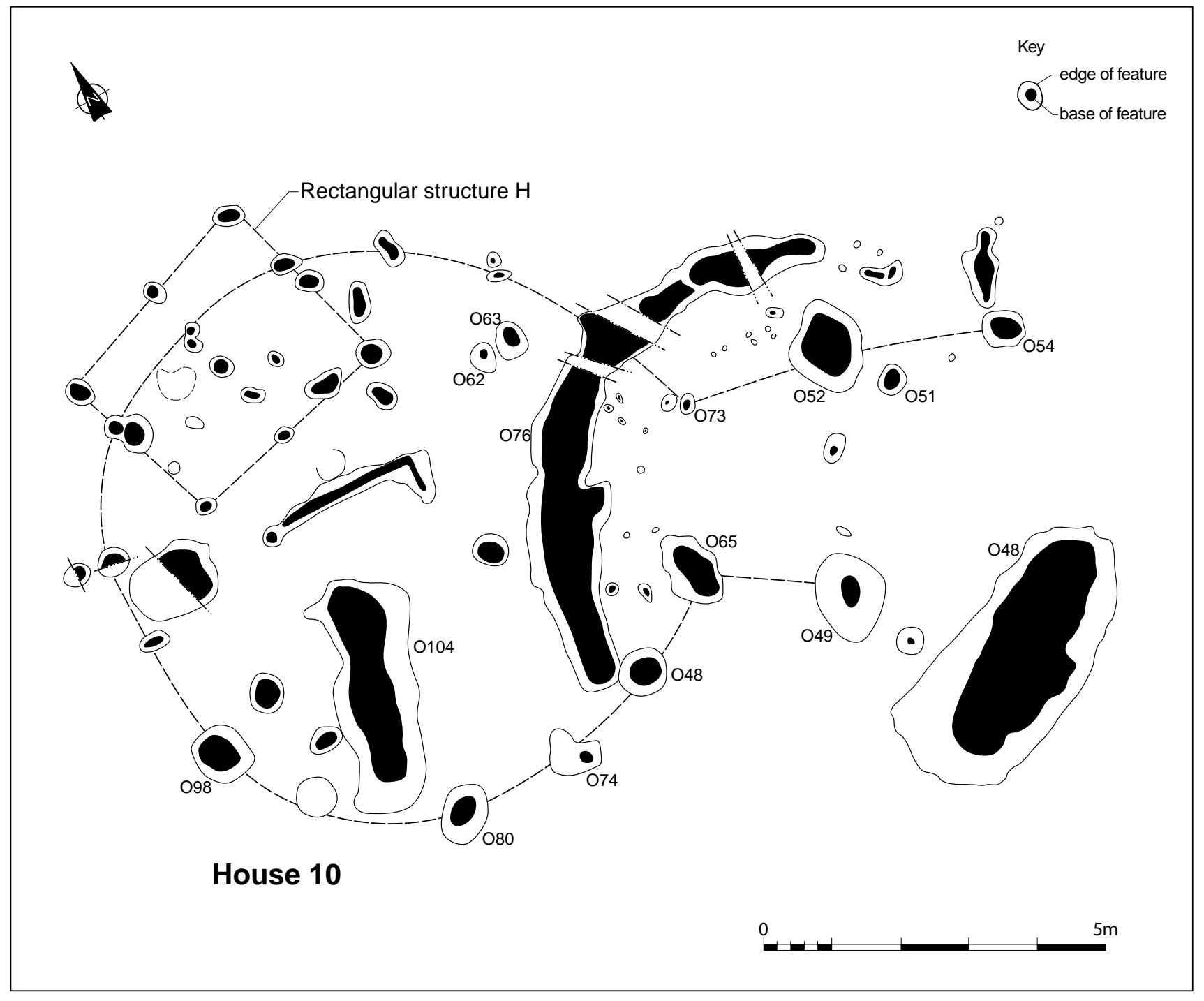

Illus 29 Plan of putative House 10 and rectangular structure $H$

confirmation of stratigraphic sequence at the point where posts belonging to both structures appeared to abut or intersect. Pit O104 appears too large and incongruous to have been an internal feature of the building, but it is admitted that this interpretation is an assertion without stratigraphic proof.

\subsection{Ring-groove building}

\subsubsection{House 9 (illus 30; illus 31)}

Description The poorly preserved remains of what appear to be a ring-groove building were located in the south-east quadrant of the outer enclosure, $c$ $10 \mathrm{~m}$ south-west of House 2. House 9 measured $c 8 \mathrm{~m}$ in diameter, and most of its surviving structural and internal features were only $0.2-0.3 \mathrm{~m}$ deep.

Its wall line was defined by the partial remains of a ring-groove and a curvilinear arrangement of post-holes, some of which were incorporated into the ring-groove. Two sections of ring-groove were preserved as definite archaeological features. Curving drying marks were visible during the excavation on the subsoil surface between these, and appeared also to define the wall alignment (shown on illus 30 but not visible on illus 31 ). Some drying marks indicated to the excavators the possibility of diverging walllines, with the implication of structural phasing, but the vestigial nature of this evidence urges caution in drawing any firm conclusions. The entrance to the building was on its south-east side, between posts L109 and L112. Two post-pits containing two separate sockets (L110-11; L129-30) may represent the foundations of the outer end of a projecting roofed porch or unroofed passage $c 1.7 \mathrm{~m}$ wide and long.

A scatter of pits, post-holes and scoops was present within the internal floor space. These formed no particular pattern, although the very centre of the floor space appears to have been clear of them. It was 


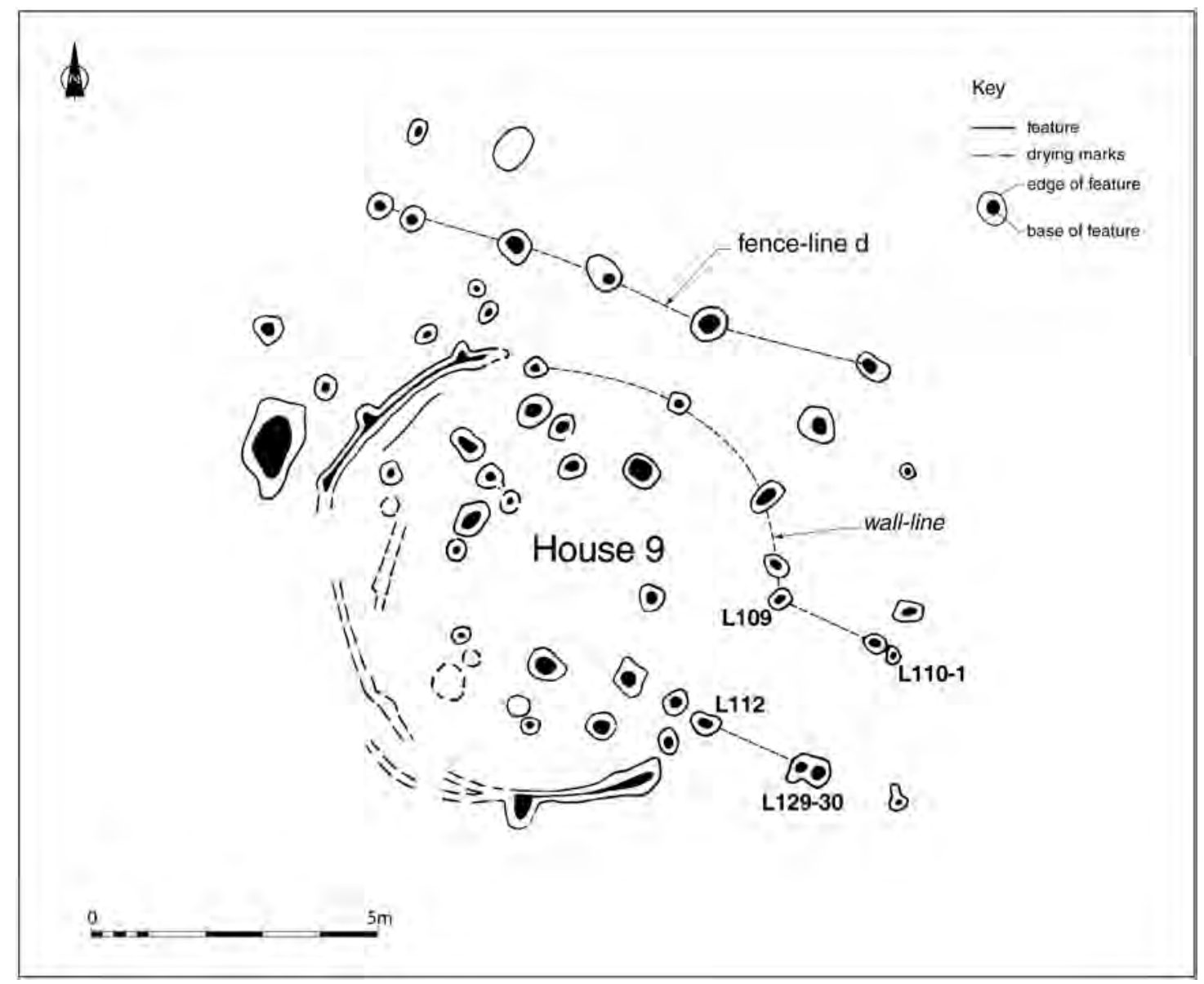

Illus 30 House 9 plan

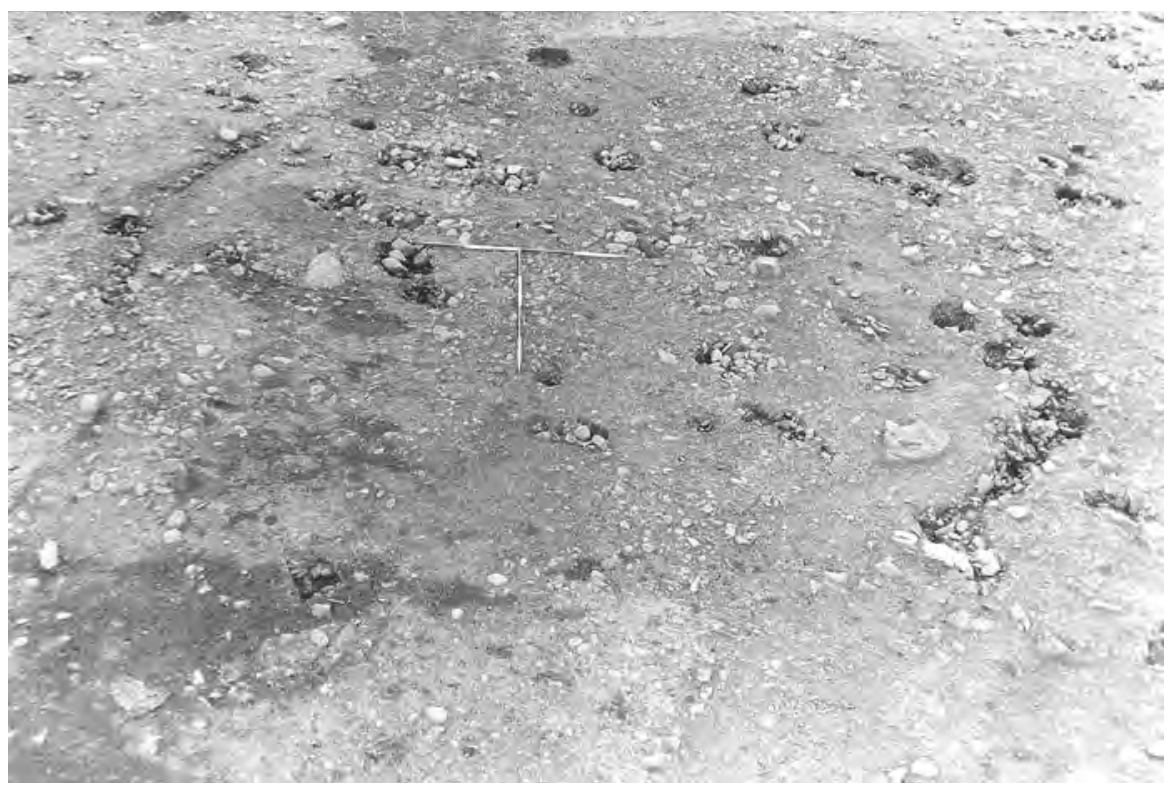

Illus 31 House 9 during excavation; from south-west; the sections of ring-groove detected only as drying marks are not visible on this shot

not possible to identify an inner post-ring, although given the small size of the building it is doubtful that such arrangements would have been necessary, practical or desirable. There was no evidence for a central roof support post-hole.

An oval boulder with a patch of polish on its surface 
was recovered from internal pit L118 (coarse stone, Cat no 59).

Reconstruction House 9 was relatively small by comparison to the other buildings identified at Dryburn Bridge. Its wall appears to have been timber-framed but, given the lack of evidence for any internal or external post-rings, this must have been strong enough to have been the primary support for the roof of the building (presuming that it had a roof). Possible evidence for structural phasing has been mentioned above, but cannot be substantiated given the inconsequential nature of the evidence encountered in excavation.

Stratigraphic and spatial relationships House 9 had no stratigraphic links with other elements of the site, although it is possible that a contemporary fence-line (illus 3, d; illus 30) was present on the north side of the building (see Section 7.7.4).

Radiocarbon date One of the inner entrance posts (L112) contained the burnt stump of an oak post. A sample was submitted to Glasgow University for radiocarbon dating $c$ 1980. Re-dating was undertaken in 2003 owing to concerns over the precision of the original date (see Section 2.2.3). The results of the two dates are shown in Table 8, with calibrated ranges in both cases calculated using $\mathrm{OxCal} v 3.5$ (Bronk Ramsay 2000).

The date returned falls within the well-known plateau in the calibration curve that spans the Early Iron Age and prevents close dating. Timber roundhouses with ring-groove foundations were built from the mid second millennium cal $\mathrm{BC}$ until the early first millennium cal AD, but concentrated in the first millennium cal $\mathrm{BC}$ (discussed in eg Cook 2000; Strachan \& Dunwell 2003), and thus the radiocarbon date for House 9 at Dryburn Bridge is uncontroversial.

\subsection{Ring-ditch buildings}

\subsubsection{House 3 (illus 32; illus 33; illus 34)}

Description The surviving remains of House 3 measured $c 9.8 \mathrm{~m}$ in external diameter. The preserved features of the building can be divided into four elements: the foundations of an internal post-ring; entrance foundations; the ring-ditch forming the peripheral internal floor space; pits within the central floor space. Ploughing appears to have removed any traces of deposits and features above the level of the subsoil surface, and archaeological survival was restricted to negative features.

The post-ring ran around the inner edge of the ring-ditch, with a diameter of $6.8 \mathrm{~m}$. It appears to have comprised 13 uprights set at $c 1 \mathrm{~m}$ intervals around its circumference. At some post positions, pairs of adjacent sockets were present, which may indicate the replacement of posts during the use-life of the building (for example E17/E18; E38/E39; E28/ E49). However, at the majority of positions there was no evidence for post replacement. The post-pits generally survived to $0.2-0.3 \mathrm{~m}$ deep, and frequently contained evidence of disturbed stone packing.

The entrance to House 3 was located on the southeast side of the building. Its position was defined on the interior by two large post-pits set $c 2 \mathrm{~m}$ apart (E22/E8), with a third located centrally between them (E9). Two further post-pits (F6, F40) appear on grounds of spacing to form the external face of the entrance structure, which was thus $c 1.5 \mathrm{~m}$ long and $c 2 \mathrm{~m}$ wide.

The ring-ditch defined the peripheral floor space of the building from its south to north-east sides, and approximately two-thirds of its circumference. This feature was $c 1.5 \mathrm{~m}$ wide, with a shallow and irregular profile up to $0.2 \mathrm{~m}$ deep (illus 34 ). The ring-ditch was filled by stones, sand and gravel, and there was no evidence for accumulations of occupation debris either within or beneath the filling material. A small number of pits were identified within the ring-ditch, particularly to the north, most of which were visible within the exposed surface of the ring-ditch fill. Flat slabs lay on the surface of the fill at various locations, but particularly to the west, and appear to represent deliberately laid paving. To the west, paving slabs were demonstrated to overlie infilled pit E46. There is thus sufficient stratigraphic evidence to be confident that the remains associated with the ring-ditch comprise at least two phases of use. In its first phase the ditch was an open, sunken feature. Its second was defined by the filling in and partial paving over of the ring-ditch. Interpretation of the stratigraphic relationship between the ring-ditch fill and the pits within the ring-ditch is not straightforward (see the description of House 8 in Section 7.4.2 for an elaboration of this point).

Six pits were present within the central floor space of the building, and seem likely to relate to the occupation of House 3. None of these features revealed

Table 8 Radiocarbon dates from House 9

\begin{tabular}{|c|c|c|c|c|c|c|c|c|}
\hline Lab no & $\begin{array}{l}\text { Sample } \\
\text { context }\end{array}$ & Material & $\begin{array}{l}\text { Lab } \\
\text { age }\end{array}$ & $\begin{array}{l}\text { Lab error } \pm \\
1 \text { sigma }\end{array}$ & $\begin{array}{l}\text { 2-sigma range } \\
\text { using lab } \\
\text { error (cal } \mathrm{BC} \text { ) }\end{array}$ & $\begin{array}{l}\text { Adjusted } \\
\text { error } \pm \\
1 \text { sigma } \\
\end{array}$ & $\begin{array}{l}\text { 2-sigma range } \\
\text { using adjusted } \\
\text { error (cal } \mathrm{BC})\end{array}$ & $\begin{array}{l}\delta^{13} \mathbf{C} \\
(\% o)\end{array}$ \\
\hline GU-1286 & $\begin{array}{l}\text { House } 9 \text {, post } \\
\text { L112 }\end{array}$ & Quercus & 2400 & 55 & $770-380$ & 110 & $800-200$ & -25.0 \\
\hline $\begin{array}{l}\text { AA-53704 } \\
\text { (GU-10812) }\end{array}$ & $\begin{array}{l}\text { House } 9 \text {, post } \\
\text { L112 }\end{array}$ & Quercus & 2475 & 40 & $770-410$ & & & -24.2 \\
\hline
\end{tabular}




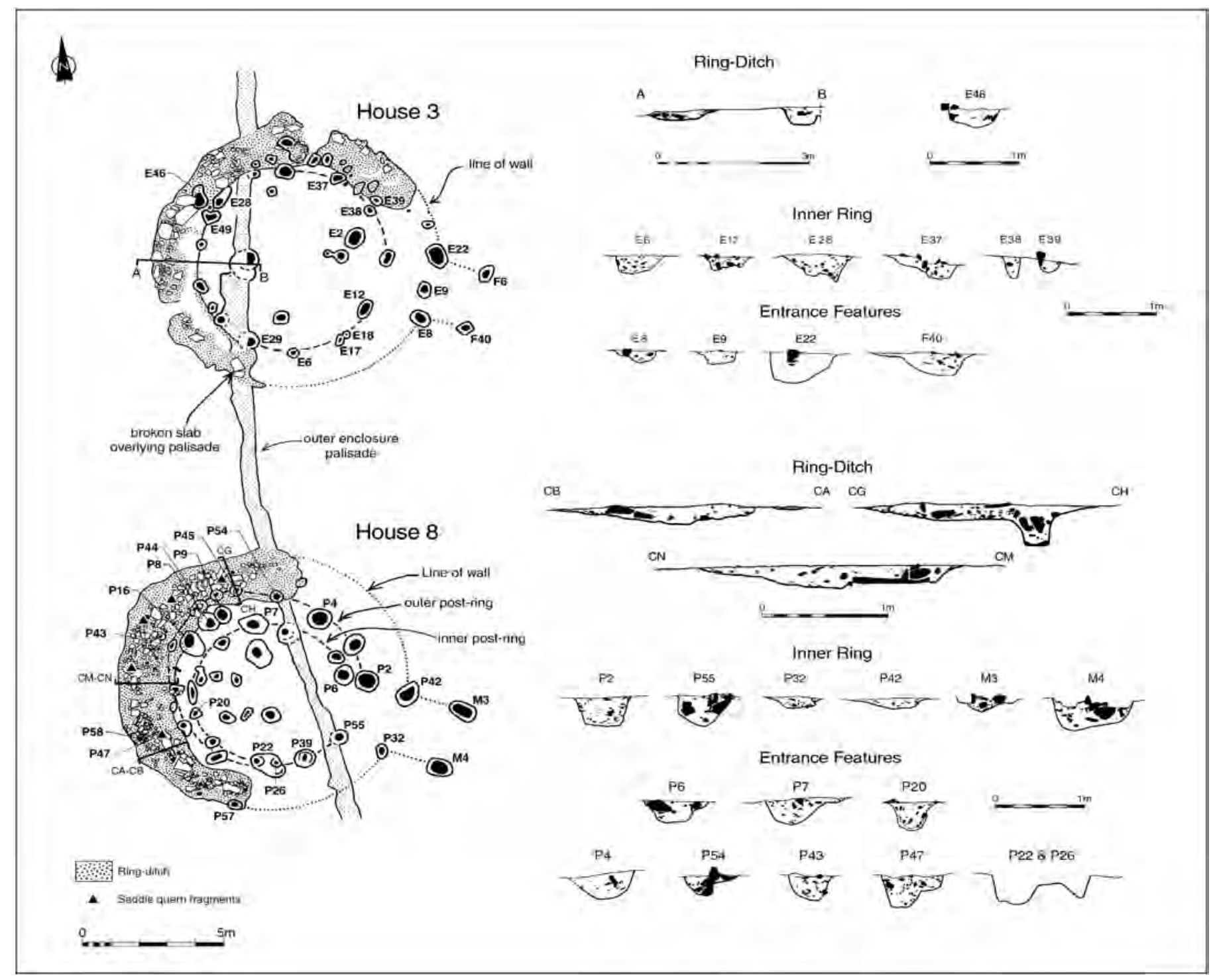

Illus 32 Houses 3 and 8; plans and selected sections

any evidence of function. There were no surviving remains of a hearth, and no evidence of scorching to suggest where it might have been located (in common with all other buildings excavated at the site).

A small assemblage of artefacts was recovered from the features of House 3. Coarse pottery came from the ring-ditch fill (Cat no 44) and from doorposts E22 and E8 (Cat nos 42-43; illus 58 for Cat no 42). A complete saddle-quern was contained within the upper fill of Pit E2 (coarse stone, Cat no 5), but was not placed in a useable position. A worked rectangular stone with a shallow cup on its upper face formed part of the ring-ditch paving on the west side of the building (coarse stone, Cat no 33), and another dished stone was also found in the ringditch fill (coarse stone, Cat no 47, illus 60). Modern glass from pit E2, along with modern glass, pottery and a clay pipe stem from the ring-ditch fill, must represent intrusive material introduced through plough disturbance. Animal bone comprised only a few fragments of unburnt bone, as well as calcined fragments from a range of contexts. No material suitable for isotopic dating was recovered.

Reconstruction House 3 comprises the remains of a roundhouse incorporating a peripheral ring-ditch. The roof of the building was probably supported both by the post-ring and the external house wall, of which no archaeological trace survived. The inside end of the entrance likely defines the wall alignment of House 3, which presumably ran around the outer edge of the ring-ditch for most of its circuit (as discussed by eg Reynolds 1982). Triscott had suggested that the wall lay between the outer edge of the ring-ditch and the paving within it (Triscott $1982,119)$ but, in the absence of foundation slots or post-sockets within the ring-ditch, such an interpretation is not preferred. Given the absence of any foundation slot/ring-groove running externally to and concentrically with the ring-ditch (for example as identified at High Knowes, Alnham, House 1, 


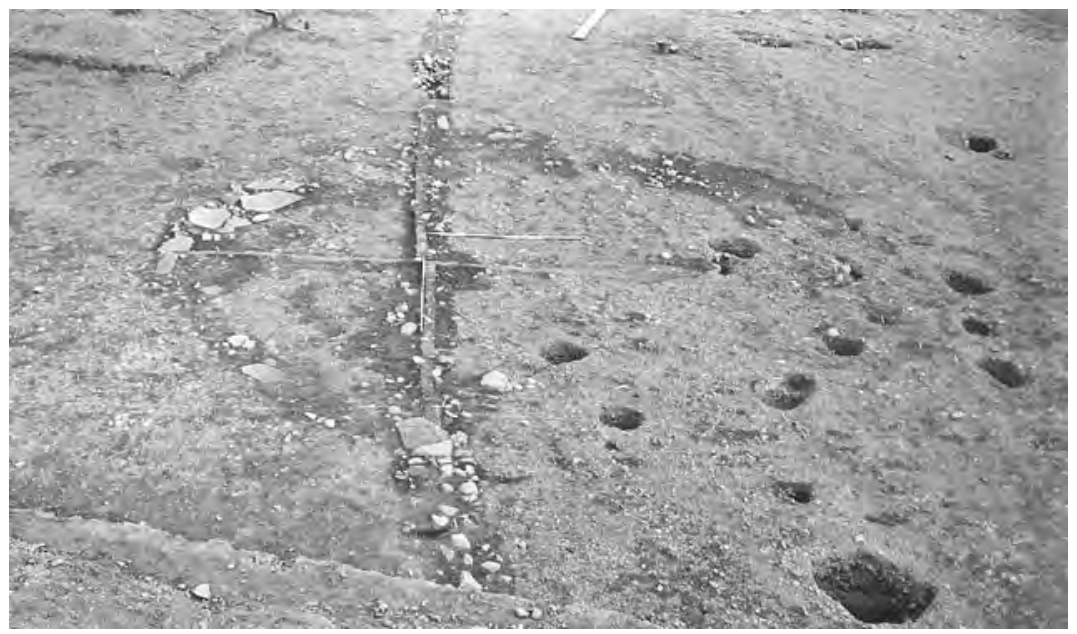

Illus 33 House 3 from south; with outer enclosure palisade overlain by ring-ditch slab (see illus 32)

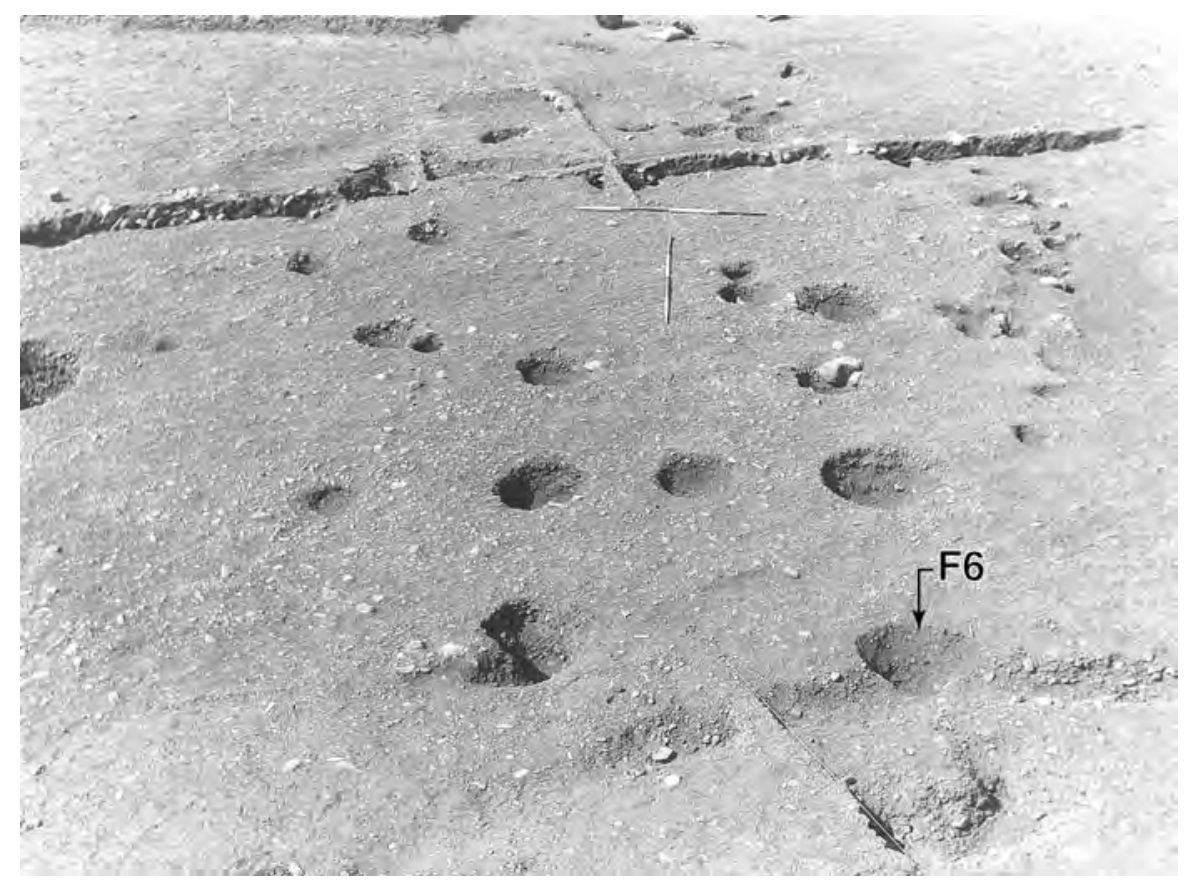

Illus 34 House 3; as excavated; showing slightness of ring-ditch and porch post F6 truncating linear feature F2 (illus 3; f) in foreground

Jobey \& Tait 1966; and Dryburn Bridge House 2, Section 7.4.4), a turf or stone wall construction can be countenanced (cf Kendrick's reconstruction of a Douglasmuir ring-ditch house; Kendrick 1995, 62 . The lack of archaeological evidence for either a foundation slot or a turf wall can be explained as an artefact of plough-truncation.

As the width of the house wall is not known, it cannot be determined whether the entrance foundations relate to an entrance passage set within the overall thickness of the house wall or to a porch structure projecting outside it, or indeed to a combination of both. The inner end of the entrance appears to have been provided with a double door, possibly with each door hung from the outside of the entrance passage and closing to the centre. A further door could have been present at the outer end of the entrance, thus providing a vestibule or porch.

Refurbishment is evidenced by the replacement of certain uprights of the post-ring and by the alterations to the ring-ditch, which must reflect a change in its principal function. It is tempting to conflate the stratigraphic evidence into two discrete structural phases, with the secondary phase defined by a replacement of some of the inner roof support uprights (and potentially the roof itself) and a change of function to the peripheral ring-ditch. However, better evidence from House 8 suggests a contrary sequence, although there is no reason to 


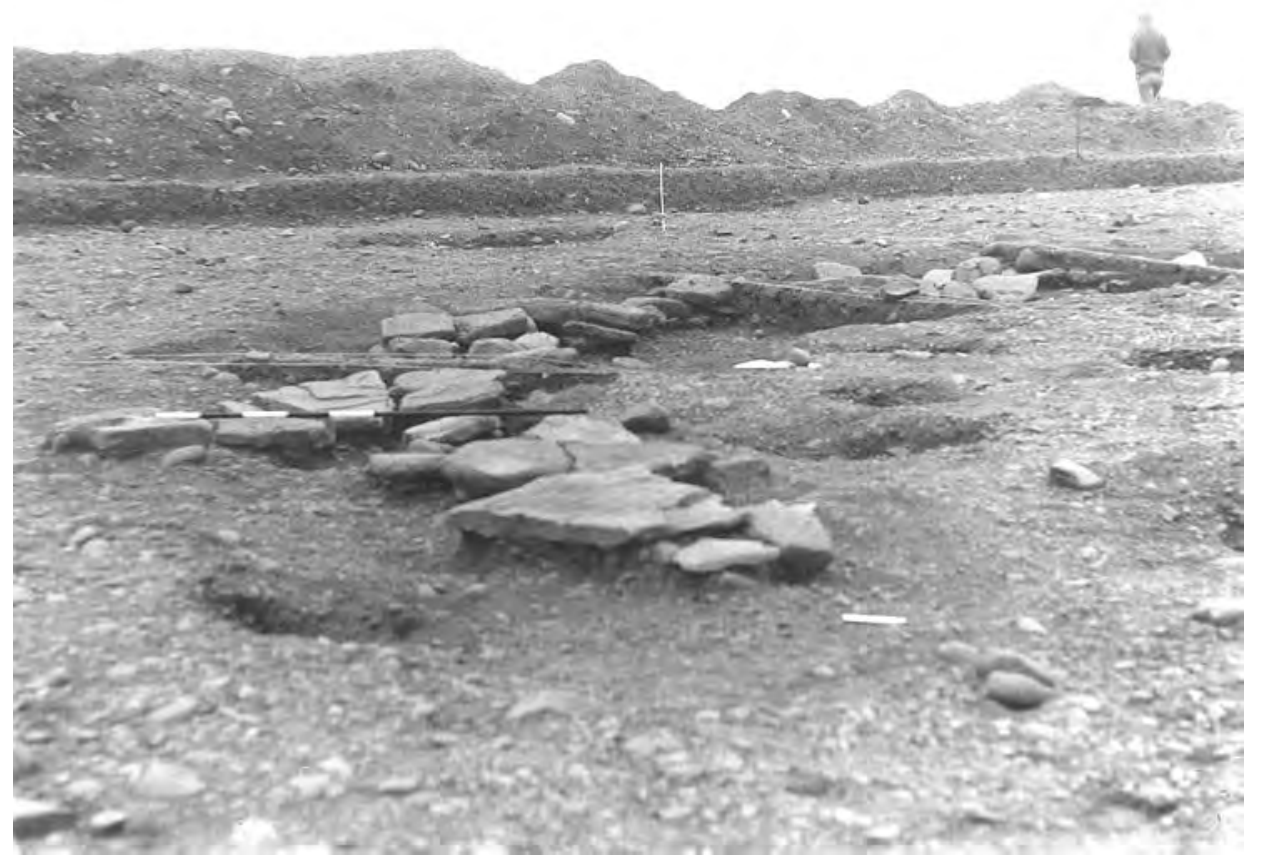

Illus 35 House 8; detail of paving within ring-ditch; from south

pre-suppose that the two buildings had identical structural histories.

Stratigraphic and spatial relationships Certain important stratigraphic relationships were established. The foundation trench of the outer enclosure was cut through by both the ring-ditch and post-pit E29 of House 3. The stratigraphic relationship between the outer enclosure palisade trench and ring-ditch is particularly clear in illus 33 , where a paving slab within the ring-ditch directly overlies the palisade trench alignment. Also of significance was the demonstration by the excavators that the outer porch post F6 truncated linear feature F2 (illus 34; illus 3, f). The linear feature itself partly truncated Burial 8 (see Section 7.7.6), providing good stratigraphic evidence that this burial predated the construction of House 3.

\subsubsection{House 8 (illus 32; illus 35)}

Description House 8 was of comparable size and character to House 3, and had been truncated by ploughing to a similar degree. Its surviving remains measured $c 10 \mathrm{~m}$ in external diameter, with an entrance to the south-east. Its preserved features can be divided into the same elements as noted for House 3, although in this case two non-concentric post-rings are demonstrable and relate to two successive building phases.

The outer post-ring described a slightly oval area of $c 7 \mathrm{~m}$ north-west/south-east by $6.5 \mathrm{~m}$. It comprised at least 13 post-pits set $c 1 \mathrm{~m}$ apart, with a $2 \mathrm{~m}$ spacing across the axis of the entrance passage (between
P2 and P55). Two additional features were present between the more regularly spaced post-pits, one occurring to the north and the other to the west. The post-pits generally measured $0.4-0.7 \mathrm{~m}$ wide by $0.2-0.4 \mathrm{~m}$ deep (illus 32 ), some containing evidence of disturbed stone packing. The four northernmost posts, in an arc from P43 to P54, were set along the inner edge of the ring-ditch.

The inner post-ring defined a circular space $c$ $5.5 \mathrm{~m}$ in diameter. This ring comprised either 11 or 12 post-settings comparable in character to those of the outer ring. Indeed, both rings appear to have shared settings P55 and P39, although neither displayed clear evidence of post replacement. Adjacent to these, however, a large post-pit at the point of divergence between the two rings appears to have contained a setting relating to both the inner (P22) and outer (P26) post-rings. The inner ring also had a $2 \mathrm{~m}$ wide spacing across the alignment of the entrance passage. In this case the alignment of the posts (P55, P6) was not perpendicular to the axis of the entrance passage, as was the case for the comparable posts of the outer ring (P55, P2). This irregularity provides circumstantial evidence that the outer post-ring was the earlier feature.

The entrance position was defined by two $0.15 \mathrm{~m}$ deep post-pits set $2 \mathrm{~m}$ apart (P32, P42). Two further post-pits (M3, M4) appear to define the outer end of an entrance structure comparable to that identified at House 3. As for House 3, the positions of the inner entrance posts (P32, P42) probably defined the alignment of the outer wall of House 8 , which presumably ran around the outer edge of the ring-ditch. Two post-settings identified along the outer rim of the ring-ditch may relate to the 
external wall (P57, P58) although, as for House 3, this wall was probably primarily a turf or stone construction.

The ring-ditch formed the peripheral floor space of the west half of House 8. It was $1.5-2 \mathrm{~m}$ wide, with a shallow and irregular profile $0.15-0.2 \mathrm{~m}$ deep which deepened to the north. It contained a brown sandy fill, within and upon which was laid a $c 1 \mathrm{~m}$ wide band of paving, comprised of flat slabs of various sizes forming a roughly level surface (illus 35). As identified at House 3, the paving thus does not appear to have formed a primary component of the ring-ditch feature. Of those post-pits of the outer post-ring that lay within the ring-ditch, at least one (eg P45, illus 32) was visible within the ring-ditch fill. While this evidence could be used to argue the post-pit as cut through, and thus secondary to, the ring-ditch fill, it also possible that the ring-ditch fill was deposited around a pre-existing post. This latter explanation implies that the post-pit was earlier than the ring-ditch fill, although not necessarily pre-dating the cutting of the ring-ditch; it is supported by the evidence from P44, where paving stones partly overlie the pit fill but appear to have been fitted around the post itself. In summary, the stratigraphic evidence tends to argue against the replacement of the outer post-ring by the inner as necessarily having been contemporary with the filling in and paving over of the ring-ditch, as the outer post-ring and paving in the ring-ditch appear to have co-existed.

Several pits were identified in the central floor space. These were of various sizes, but generally survived to no more than $0.2 \mathrm{~m}$ deep. None revealed any evidence as to their function. No trace of a hearth was identified.

The finds from House 8 were restricted mostly to a series of saddle-querns, both whole pieces and broken fragments. Five items had been incorporated into the paving within the ring-ditch (coarse stone, Cat nos 10, 17, 23, 26 \& 28), including one broken lower stone, two upper stones (one complete) and fragmented broken stones; the site records do not indicate whether or not the lower stone had been placed in a usable position (cf House 2, Section 7.4.4). Broken saddle-quern fragments had also been re-deposited within the packing of porch post M3 (coarse stone, Cat no 27). A copper alloy rod fragment was also recovered from the ring-ditch fill. Very little animal bone was found, burnt or otherwise.

Reconstruction The character of House 8 is closely comparable to that of House 3 , in as far as it can be reconstructed from its surviving remains, and is not discussed further to avoid repetition. However, the remains of House 8 revealed more stratigraphic complexity than those of House 3, demonstrating at least two construction phases. The two post-rings could not have co-existed rationally within a single building, and there are two phases of use of the ring-ditch. It is proposed that the building plan of the earlier house incorporated the outer post-ring and the ring-ditch as an open feature. The inner post-ring and the peripheral paving thus belong to a secondary construction phase. As noted above, however, the limited stratigraphic evidence suggests that both changes did not occur simultaneously, as there is some evidence to suggest that the paving within the ring-ditch was fitted around the outer post-ring. The secondary building thus appears to represent a substantial refurbishment of the primary roundhouse, rather than a de novo construction.

Stratigraphic and spatial relationships Excavation demonstrated that the ring-ditch and elements of the two post-rings of House 8 were cut through the foundation trench of the outer enclosure. This evidence of sequence concurs with that obtained for House 3.

\subsubsection{House 7 (illus 36; illus 37; illus 38)}

Description House 7 was slightly smaller than the neighbouring ring-ditch structures, its surviving remains, within the presumed wall line, measuring $c$ $8.5 \mathrm{~m}$ in diameter. It was poorly-preserved, with most features surviving less than $0.2 \mathrm{~m}$ deep. Moreover, the scatter of internal features was denser and less readily interpretable than for Houses 3 and 8 .

The ring-ditch formed the most distinctive element of House 7. It continued around most of the circuit of the building, apart from a $c 3 \mathrm{~m}$ gap to the south-east. The ring-ditch measured up to $2.5 \mathrm{~m}$ wide, surviving up to $0.5 \mathrm{~m}$ deep to the north but of negligible depth to the south (illus 36 , section). This variable preservation reflects the fact that House 7 was terraced slightly into a south-facing slope. The ring-ditch contained paving slabs around the west side of the building (illus 37), with cobbles present within the remaining areas. In contrast to Houses 3 and 8 , these stone features appear to have been set directly on the base of the scoop.

While the presence of a post-ring could be anticipated by comparison with Houses 3 and 8 , it is not readily detectable. Four post-holes were identified around the inner edge of the ring-ditch on the north side of the building, in an arc from K82 to $\mathrm{K} 51$, and may have formed components of a post-ring. However, these features survived only to $0.15-0.2 \mathrm{~m}$ deep, in that part of the site where quality of preservation was better. To the south only K65 and K61 could be reasonably interpreted as part of a post-ring, but K65 survived less than $0.1 \mathrm{~m}$ deep, emphasizing how much information may have been lost. Excavation revealed several features cut into the base of the ring-ditch, towards its outer edge on the north and west. Some were stone-packed post-holes and others were simply depressions (possibly post impressions) in the subsoil. These features occurred at $2-3 \mathrm{~m}$ intervals, and might be related to the wall 


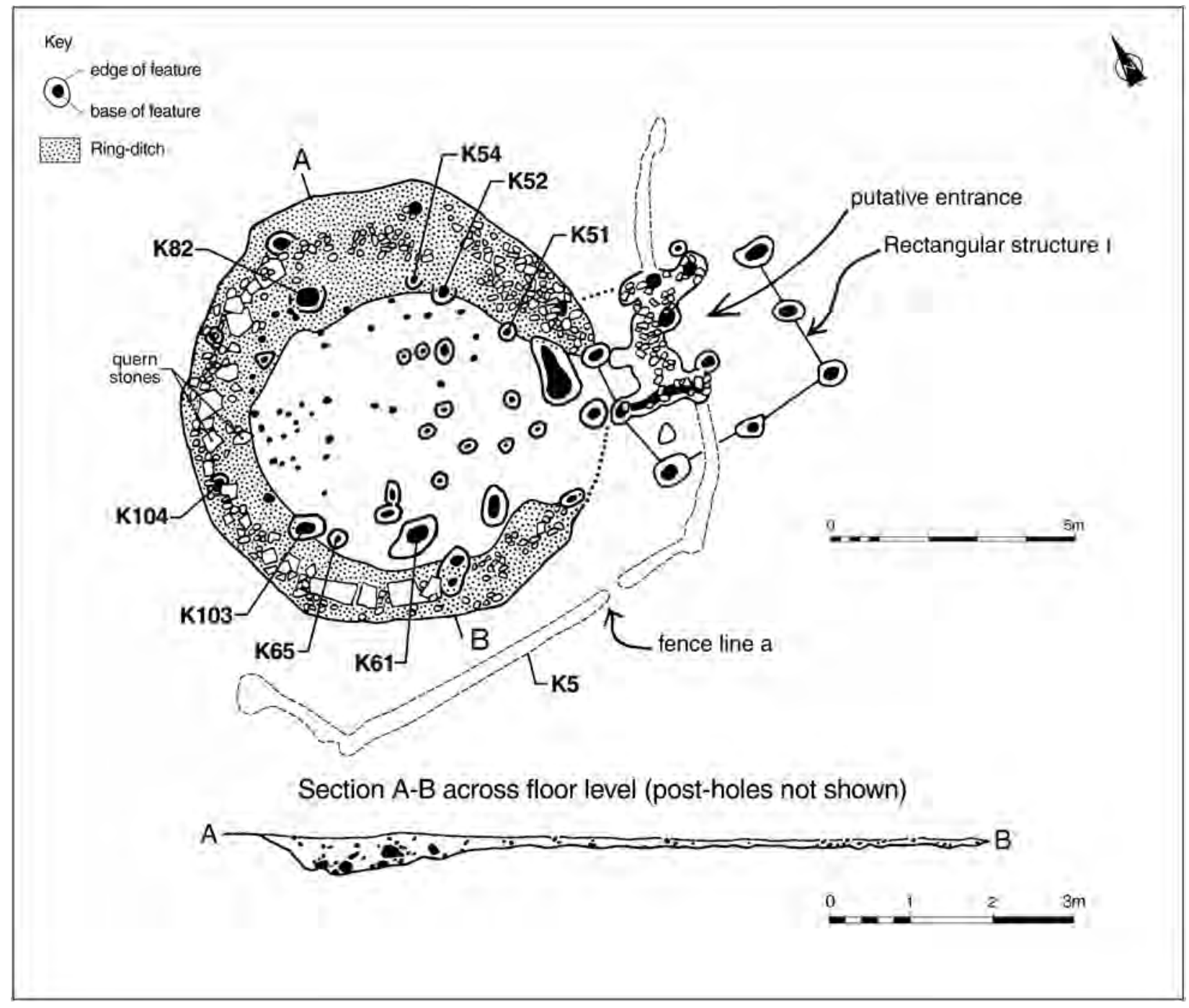

Illus 36 House 7; plan

of House 7, possibly representing the foundations for the timber framing of a wattle and daub wall. However, some of the features (eg K104) were sealed directly beneath paving within the ringditch, and thus cannot relate to the later use of the building.

The central floor space, within the ring-ditch, measured $c 5.5 \mathrm{~m}$ across. Excavation detected a density of post-holes, stake-holes, pits and stonefilled hollows in this area (illus 38 ). The stake-holes tended to be concentrated in the rear half of the building and the post-holes in the front half. It is possible to pick out alignments within the stakeholes that might be used to extrapolate the presence of stake-built structures, such as internal partitions. However, it would be unwise to extrapolate too far on the basis of these heavily truncated remains.

While it is clear that the entrance to House 7 lay on the south-east side of the building, reconstruction of its precise form is problematic, not least because of the complex series of features which coincide in the entrance area, including rectangular structure I (Section 7.5). The entrance arrangement suggested on illus 36 was proposed by the excavators, and comprises four posts defining a passage $c$ $2.5 \mathrm{~m}$ wide and $2 \mathrm{~m}$ long, with the south-west side of the passage appearing defined by a foundation slot that lay within the south-west end of an irregular stone-filled hollow. The hollow was probably not a deliberately excavated feature, but rather the archaeological manifestation of a series of closelyspaced and inter-cutting post-pits (although the sequence of pit cutting was not determined stratigraphically during the excavation). The outer posts of the entrance structure may have also formed the terminal posts of a fence-line (K5) forming a partial enclosure around the south and east sides of House 7 (described in Section 7.7.1). This reconstruction of the entrance morphology is not without significant drawbacks, however, as the north-west entrance post lies within the ring-ditch, which thus projects into the proposed entrance passage. An alternative, and less elaborate, entrance could have been defined 


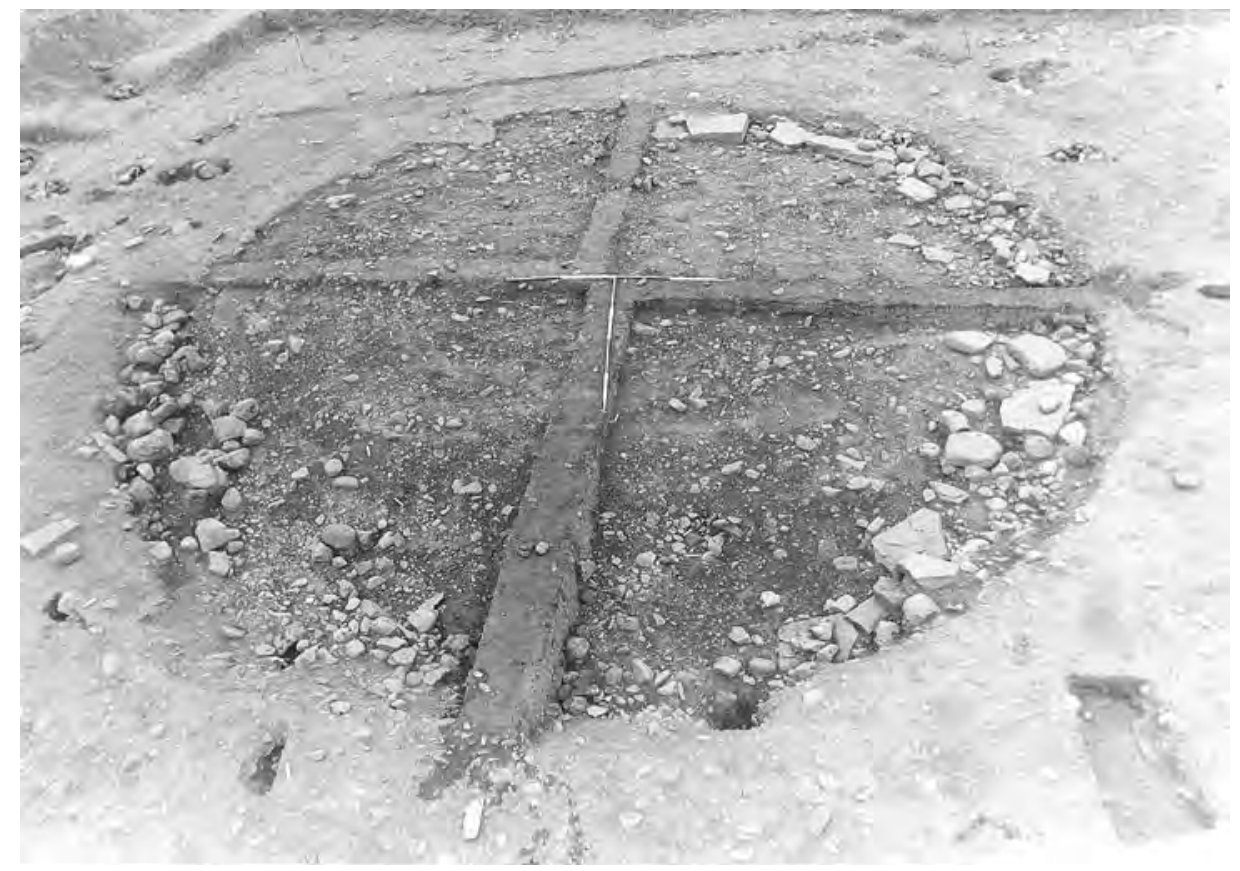

Illus 37 House 7; showing variable depth of soil overlying foundations; from north-east

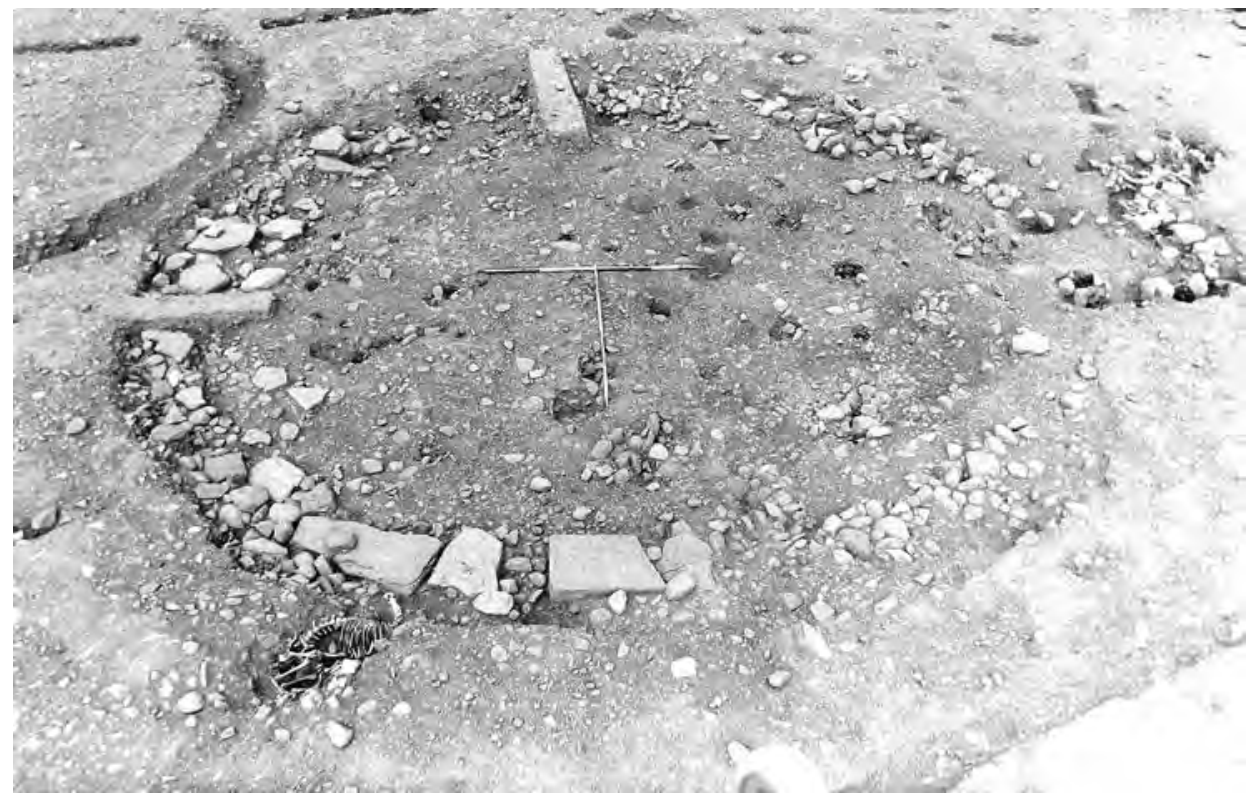

Illus 38 House 7; showing excavated foundations and entrance structure; and feature K2. The sheep burial in the foreground is considered to be a modern, intrusive feature

by the two post-holes present along the presumed wall line within the gap in the ring-ditch.

Finds recovered from House 7 included two complete saddle-quern lower stones (coarse stone, Cat nos 1, 4; illus 59) and a broken upper stone (coarse stone, Cat no 24) from the paving within the ring-ditch. Of these, the two saddle-quern lower stones were positioned side by side to the rear of the building (illus 36). Broken saddle-quern uppers had also been incorporated into the packing of internal post-holes (coarse stone, Cat nos 19 and
21, the latter from K61). Chert and flint flakes were found in the ring-ditch fill, and plain pottery was recovered from the irregular hollow within the proposed entrance structure (Cat nos 9-11, illus 58 for Cat nos 9-10). A very small assemblage of animal bone was present.

Reconstruction House 7 is comparable to Houses 3 and 8 in broad terms, comprising a peripheral shallow ring-ditch surrounding a central area containing pits and scoops. The paving is very 
similar to that recorded at House 8 and, as at both neighbouring houses, does not appear to have been a primary feature of the building. However, it is possible that the superstructure of House 7 varied from those of its neighbours. The lack of coherent evidence for a post-ring might suggest that the roof was supported by a different mechanism, although the absence of such a ring may simply be a facet of differential preservation. The posts beneath the peripheral paving suggest that, at least initially, the building may have possessed a timber-framed wall. Assuming this, then the building must have been rebuilt at some stage since the putative wall foundation posts were sealed beneath the paving. Such evidence of rebuilding would be consistent with the evidence from Houses 3 and 8.

Stratigraphic and spatial relationships The spatial relationships between House 7 and certain adjacent features are instructive. A squared curvilinear slot (K2, illus 3 ), $6 \mathrm{~m}$ long, $0.4 \mathrm{~m}$ wide and $0.3-0.5 \mathrm{~m}$ deep, runs adjacent to the north-west of the ring-ditch and is interpreted as the foundation for a fence-line or windbreak (illus 3; cf the U-shaped gullies identified at Port Seton East; Haselgrove \& McCullagh 2000). This feature could not have been contemporary with House 7, had the latter incorporated a wall of any thickness running outside the ring-ditch. A second fence-line (K5) probably formed part of a contemporary enclosure around House 7 and potentially linking with its entrance passage although, as discussed above, definitive stratigraphic proof was lacking. What appears to be a rectangular structure founded on a grid of nine post-pits was identified immediately to the east of House 7 (illus 36 ; see also illus 47, I). While no definitive stratigraphic relationships were determined between the rectilinear structure and roundhouse, the two cannot have been contemporary as the rectangular structure would have blocked access to the roundhouse.

A pit containing a sheep burial was recovered on the south-west edge of House 7, cutting into the ring-ditch (illus 38 ). The sheep had been decapitated prior to burial and the head placed beneath the torso. This burial, however, appears to have been relatively modern, given the good quality of bone preservation (compared to the human bone preserved within the Iron Age pit graves, Section 7.6), and the skeletal remains were not retained for analysis.

\subsubsection{House 2 (illus 39; illus 40; illus 41; illus 42; illus 43; illus 44; illus 45; illus 46)}

Description The remains of House 2 were located within the east central portion of the outer enclosure, $c 2 \mathrm{~m}$ within the outer enclosure boundary and a similar distance south of the inner enclosure boundary. This structure had the greatest amount of internal stratification of any present on site. The better level of preservation than elsewhere is owed to the scooping of the floor of the building into the slight south-facing slope. Features within the building had been preserved beneath a deeper accumulation of topsoil-derived material that filled the scoop after the abandonment of the building (visible on illus 41 and above paving on illus 45).

The foundation features of House 2 can be divided into the following principal elements: two ringgrooves representing wall-lines; scooped features between the ring-grooves; a ring-ditch and its fills; a post-ring representing the foundation for a roof support framework; and other internal features (illus 39). It was demonstrated that these related to more than one occupation phase.

The outer ring-groove measured $0.3-0.5 \mathrm{~m}$ wide, increasing in depth from $0.2 \mathrm{~m}$ to the south to $c 0.4 \mathrm{~m}$ to the north (illus 42 ). It had steeply sloping sides and a flat base (for example illus 40, A-B and B-D) and contained stone packing. Regularly spaced post impressions were detected on its base, particularly on the west side of the building. The ring-groove defined a circular space with a diameter of $c 13.2 \mathrm{~m}$. An entrance break was identified on its south-east side, adjacent to the outer enclosure palisade trench. It measured $c 2 \mathrm{~m}$ wide and was defined to either side by terminal post-settings $\mathrm{C} 4$ and $\mathrm{C} 5$. However, it was demonstrated that C5 had been cut through an earlier post-hole on the outer edge of the outer ringgroove at the same location (illus 40, E). The earlier post-setting projected out from, and appeared to pre-date, the construction of the outer ring-groove. A similar protuberance from the outer ring-groove was evident beside post $\mathrm{C} 4$, although in this case excavation did not confirm the presence of an earlier post. Within both $\mathrm{C} 4$ and $\mathrm{C} 5$ were the charred remains of radially split oak timbers, which presumably represent the burnt stumps of posts that formally flanked the entrance gap. An ill-defined trench ran across the entrance gap between the two terminal posts, and may be interpreted either as the foundation of a secondary blocking feature or potentially a drop-trench for a portcullis-style gate. Apart from at the entrance no evidence was detected for either replacement or refurbishment of the structure founded in the outer ring-groove.

The inner ring-groove was comparable in character to the outer, typically with a squared profile $0.4 \mathrm{~m}$ wide and $0.4 \mathrm{~m}$ deep (illus 40, A-B). It ran concentrically to the outer ring-groove, and defined an area $c 10 \mathrm{~m}$ in diameter. It incorporated a $c 2.2 \mathrm{~m}$ wide entrance to the south-east, defined to either side by terminal posts, which was aligned with that in the outer ring-groove. The terminal post to the southwest contained the charred remains of an oak timber. The north-east terminal post also appeared to have charred in situ, although in this case the timber had decayed more completely into an organic black soil. The remains indicated only a single phase of use for this feature.

A number of features were present in the zone between the two ring-grooves. In the north-west quadrant were several conjoined and irregular shallow scoops (illus 39). These features are 


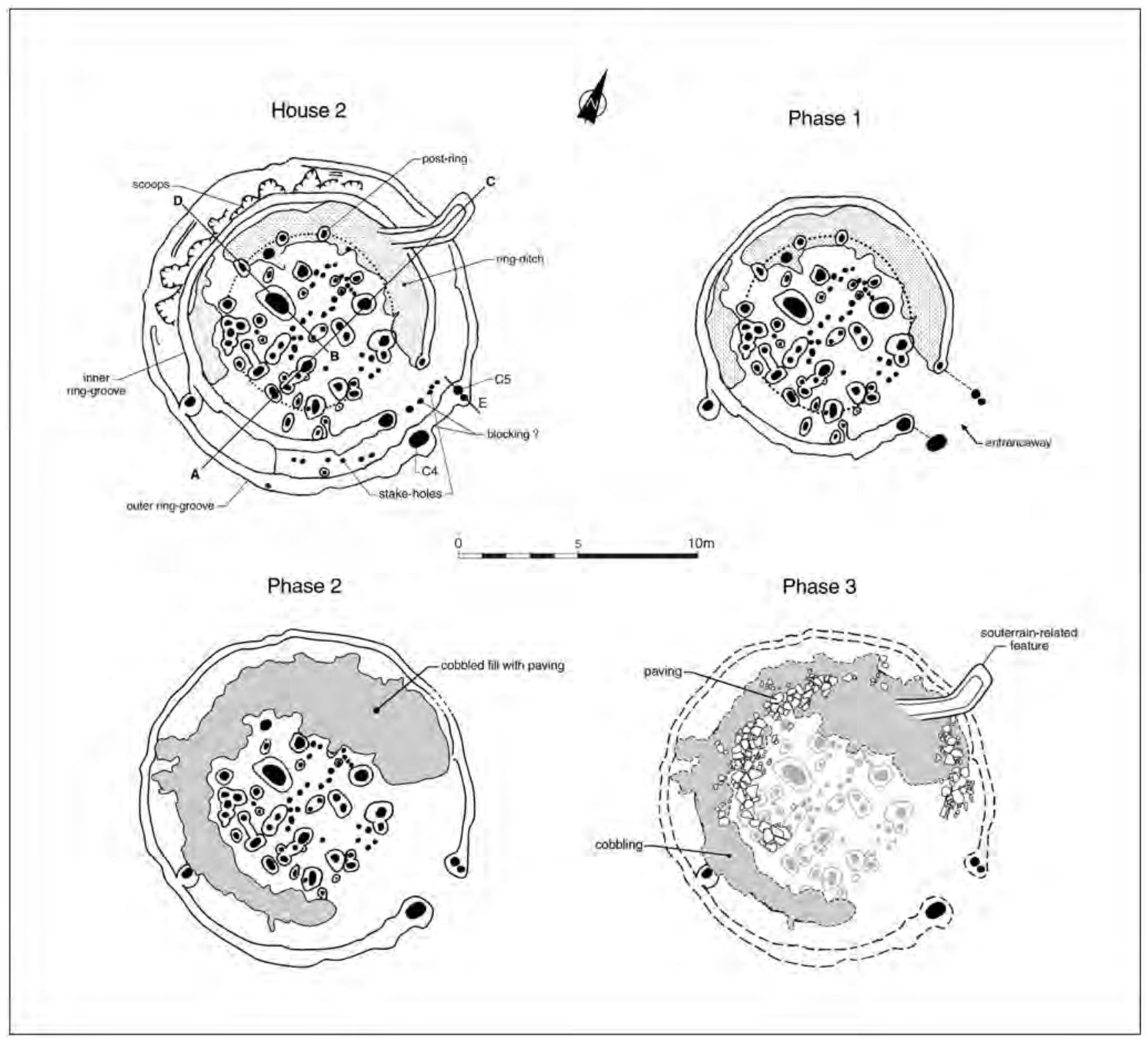

Illus 39 House 2; plans showing foundation features; and phase plans

described as a ring-ditch in the interim account (Triscott 1982, 120), and are comparable to features described as ring-ditches at other excavated sites (for example House 1 at High Knowes, Alnham: Jobey \& Tait 1966), although the scale and presumably also the function of these features differed from the more substantial ring-ditch referred to below. A row of stake-holes was present to the south-west of the entrance. A second row of five stake-holes ran across the entrance, and may be interpreted as the foundation for either a blocking feature or a screen designed to prevent direct access from the entrance to the centre of the structure. The remaining areas between the ring-grooves were devoid of archaeological features (for example on the right of illus 42 , where this zone appears as a raised area of subsoil between the cut foundation features).
Immediately within the inner ring-groove was a penannular ring-ditch comparable to those characterizing Houses 3, 7 and 8, although somewhat more substantial. It ran in an arc from the north side of the entrance around to the south-west side of the building, covering approximately two-thirds of its circumference. It was wider and deeper around the northern, up-slope side of the building, where it measured up to $c 1.5 \mathrm{~m}$ wide and $0.5 \mathrm{~m}$ deep, with sloping sides and a flat base (illus 43; illus 40, B-C). To the west the ring-ditch narrowed to less than $1 \mathrm{~m}$ wide. Its absence from the south side of House 2 is demonstrated graphically on illus 40, A-B. The ringditch had not been excavated with the intention of creating a level floor space, as to the north its base lay below that of the central floor space bounded by it. 


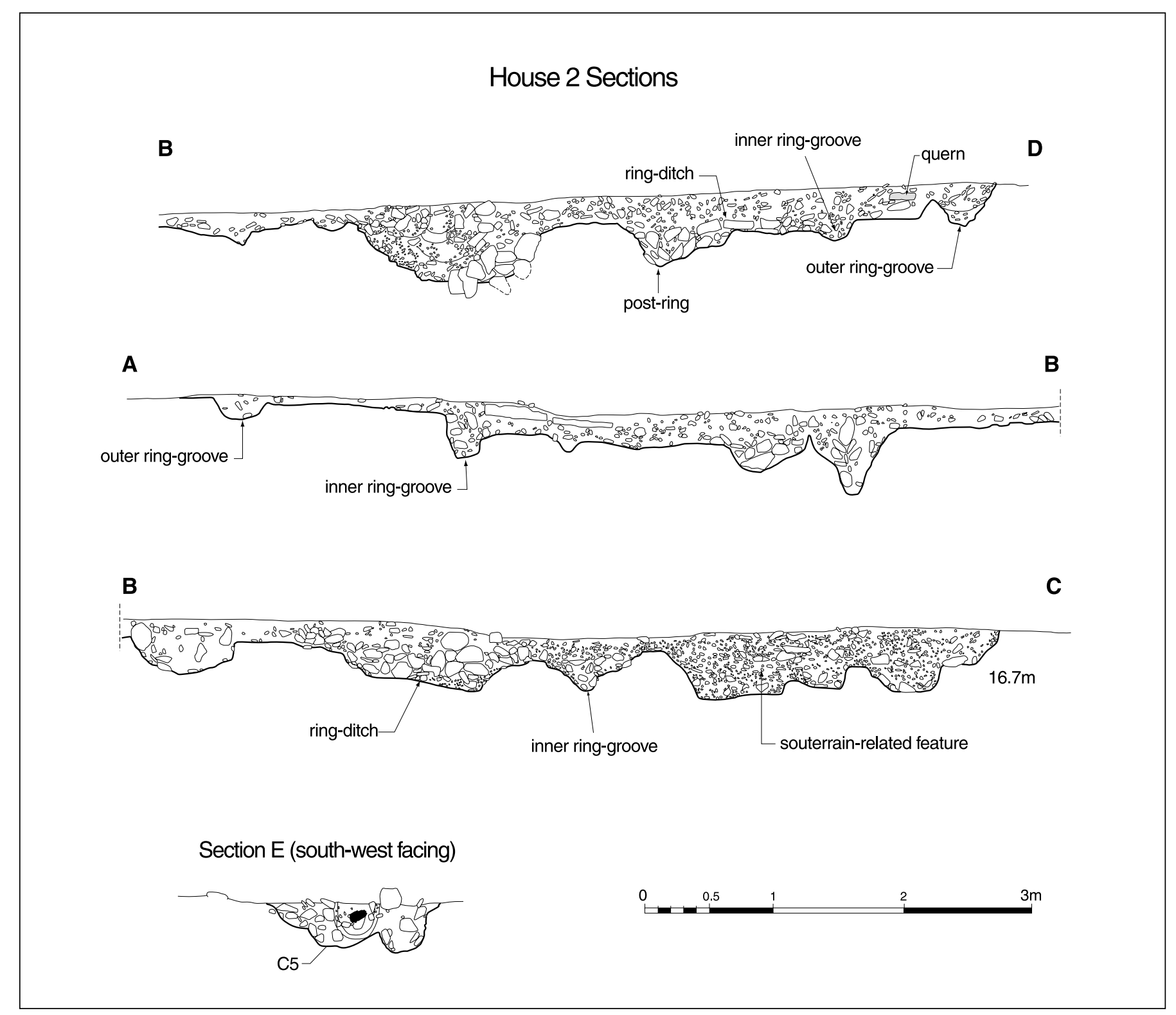

Illus 40 House 2; selected sections

The ring-ditch therefore appears to have been designed initially to function as a sunken floor space. However, this configuration was altered markedly at some stage by the infilling of the ring-ditch with a substantial deposit of cobbles and boulders to level up the floor surface across House 2 (illus 42; illus 43). The spread of cobbles sealed the inner ring-groove and the post-ring elements on the north side of the building (eg illus 40, B-C and B-D; illus 43). Both these structural elements must therefore have fallen out of use with this redesign of the internal floor space. To the south-west the cobble deposit appeared to incorporate flat stones on its surface, incorporating two saddle-quern lower stones, which may have acted as rudimentary paving (illus 42). For the most part this cobbling had a surface width of $c$ 1.5-2m and did not extend outside the circuit of the inner ring-groove, but to the north-east it widened to over $3 \mathrm{~m}$ and encroached almost to the outer ring-groove.

Set on the upper surface of the cobble deposit was a carefully laid band of paving (illus 44; illus 45). This was generally $1-1.5 \mathrm{~m}$ wide and was composed of limestone and sandstone slabs. It occurred in two arcs, the larger around the west half of the building and the smaller to the east, where it formed a less regular surface, perhaps due to the greater depth of unconsolidated cobble fill beneath it in that sector (illus 44).

On the northern side of the building excavation identified a distinctive curvilinear feature that had been cut obliquely through the ring-grooves and the cobble fill of the ring-ditch (illus 46). It measured $c$ $5 \mathrm{~m}$ long, and was $c 0.8 \mathrm{~m}$ wide and deepened to the north where it cut into the slope, reaching a depth of $0.5 \mathrm{~m}$ at its northern terminus. It had an earth and stone fill (illus 40, B-C; visible within the cobble fill 


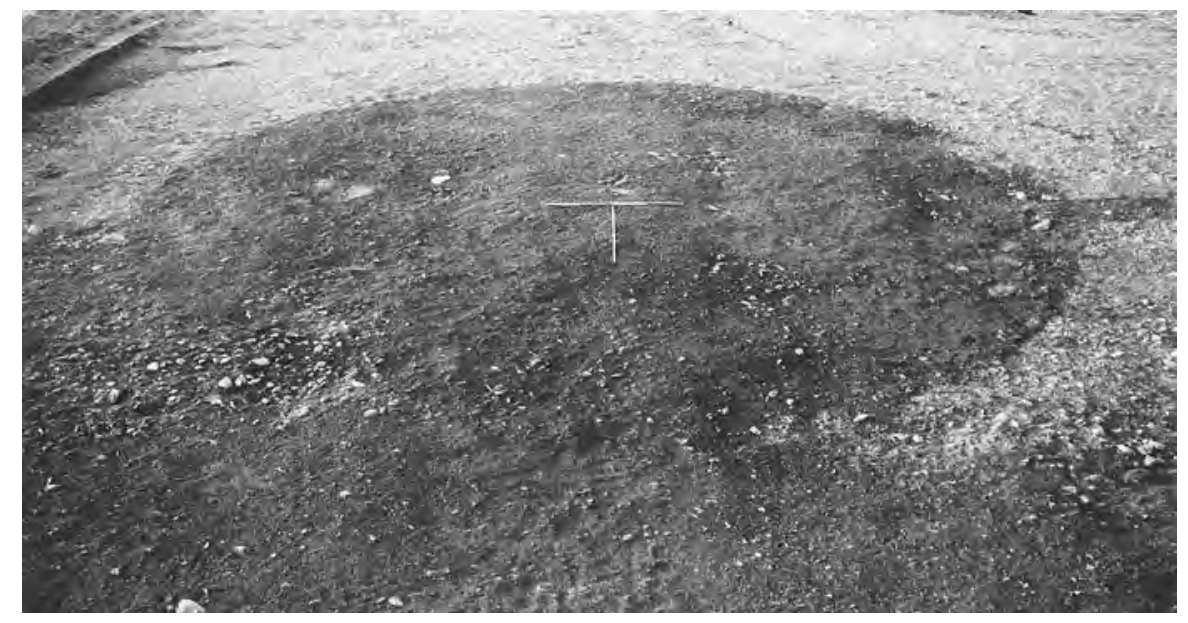

Illus 41 House 2; as initially uncovered; from east showing scoop filled with post-abandonment infill and band of hillwash CAC in foreground

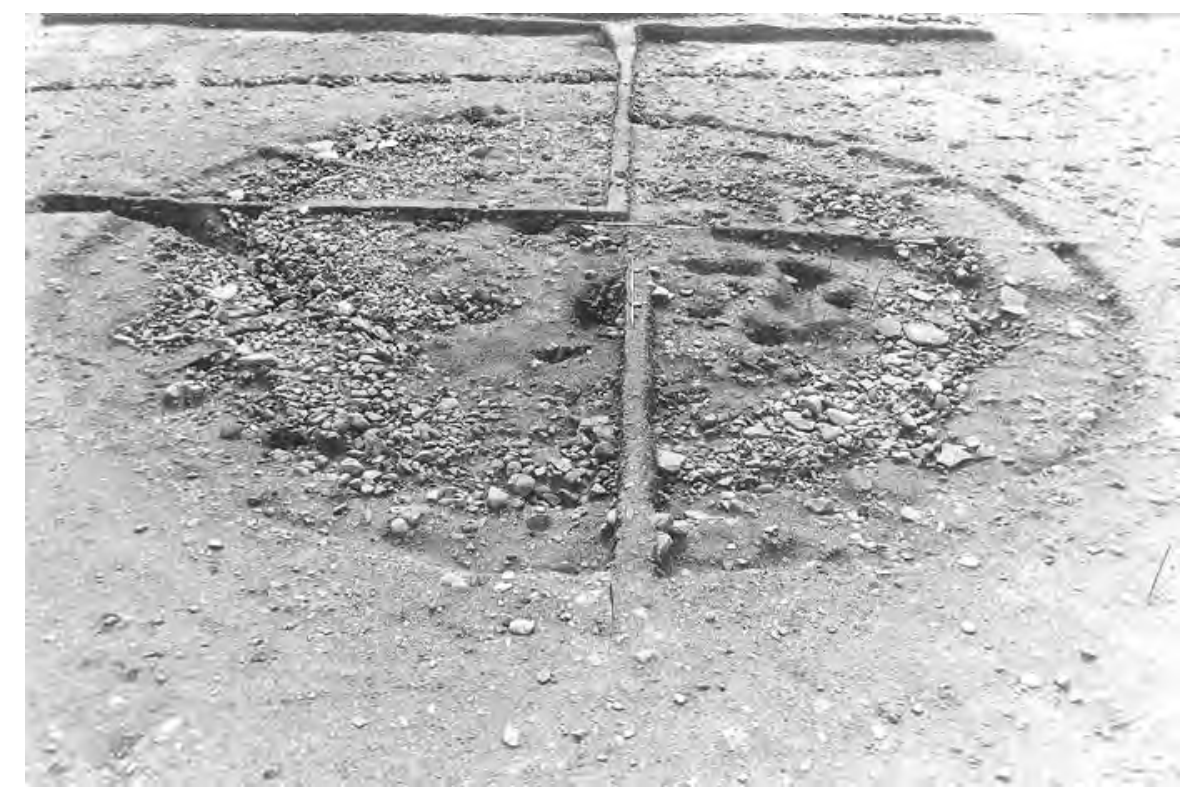

Illus 42 House 2; showing cobble fill of ring-ditch and associated paving; from north-west

of the ring-ditch on illus 46). There was no direct evidence for the function of this enigmatic feature. However, its morphology bears some similarity to that of a Dalladies-type souterrain (Watkins 1980), albeit in miniature, and perhaps it was a sunken storage feature relating to the latest stages of occupation of House 2. However, given its position within the sequence of excavated features, it could also have been created after the abandonment of House 2 (although before the scoop became infilled).

A post-ring was identified running for the most part around the inside of the ring-ditch (illus 39), although to the north three posts had been cut through the base of the ring-ditch beside its inner edge (one such is visible, filled with stones, in the right foreground on illus 43) and were sealed beneath its cobble fill. Ten stone-packed post-pits were identified, at intervals of $c 1.2 \mathrm{~m}$. No evidence for the post-ring was identified in the north-east quadrant of House 2, and its absence from this area must be regarded as puzzling and not readily explicable. The post-pits were typically $0.5 \mathrm{~m}$ wide and $0.3 \mathrm{~m}$ deep. The post-ring defined a central space $c$ $6.1 \mathrm{~m}$ in diameter. The presence of additional postsettings adjacent to certain elements of the post-ring in the south half of the building might indicate that this feature had been subject to repair.

The central floor space of House 2 contained a dense spread of stone-filled pits, post-holes and stake-holes. In several cases inter-cutting features were identified. Overlying the subsoil surface in the north-west quadrant was a near-rectangular spread of stones incorporating what the excavators described as a burnt soil matrix (visible on illus 44 to the right of the measuring scales). A rectangular stone-lined hollow, $c 0.5 \mathrm{~m}$ across internally and 


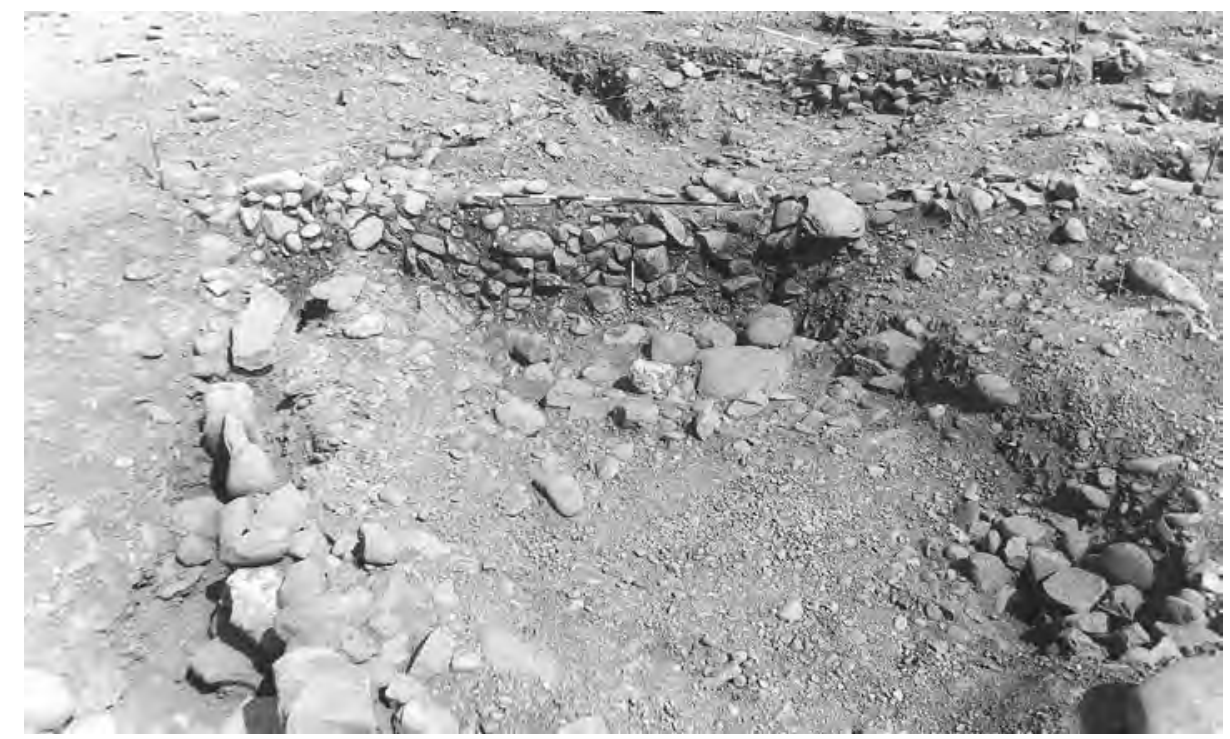

Illus 43 House 2; showing section of cobble deposit filling the ring-ditch and sealing the inner ring-groove (with packing stones still in situ) in north-west quad; from south-west

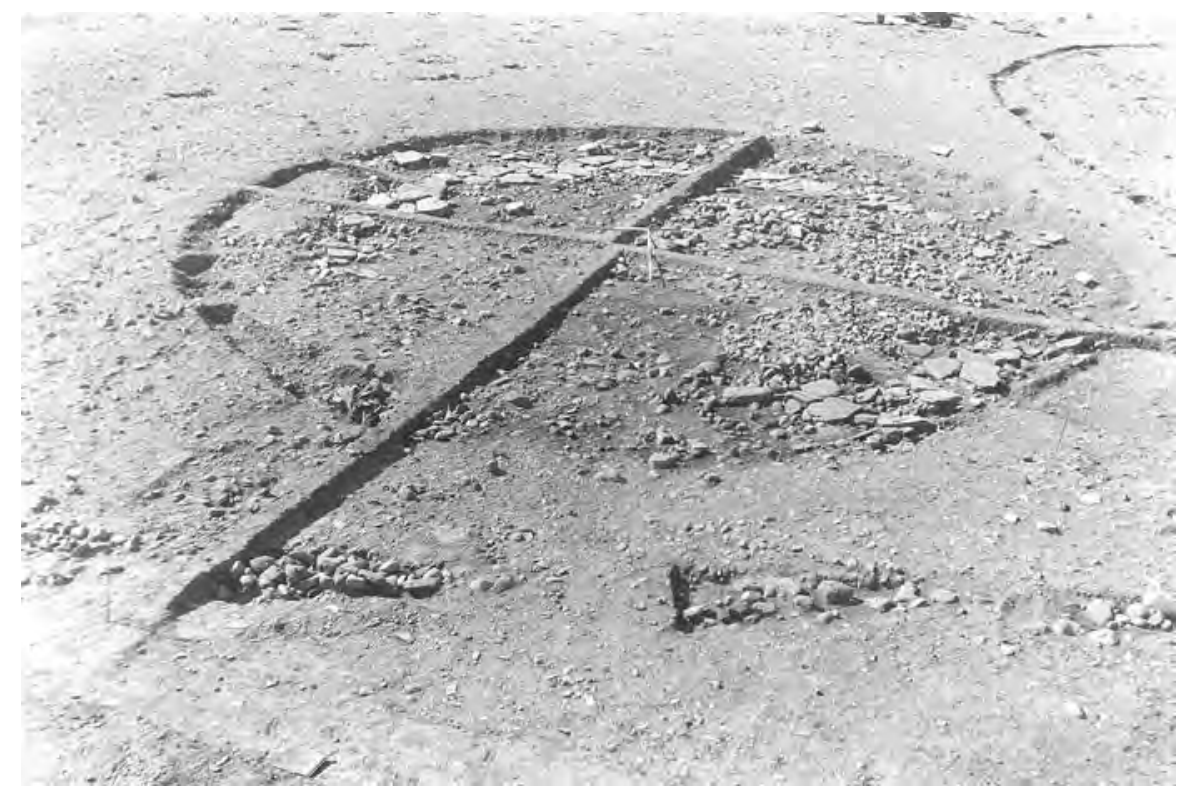

Illus 44 House 2; showing paving overlying cobble infill of ring-ditch; from south-east

$0.3 \mathrm{~m}$ deep, was present towards the very centre of the floor space: its function is unknown.

In terms of Dryburn Bridge, the finds assemblage from House 2 was substantial. Principal amongst these was an astonishing number of saddle-querns, both complete and broken. Most of these had clearly been reused, including a broken upper stone incorporated within the packing of the outer ring-groove (coarse stone, Cat no 18); broken lower stones from the inner ring-groove (coarse stone, Cat nos 12 and 15; illus 59 for Cat no 12); and one complete lower stone (coarse stone, Cat no 11) and other fragments (coarse stone, Cat nos 8-9 \& 30) from post-holes within the central floor space. Several querns were recovered from the cobble fill of the ring-ditch (coarse stone, Cat nos 2, 6, 13, 22 \& 31), including two complete lower stones incorporated in its surface paving on the south-west (coarse stone, Cat nos 2 and 6) and a complete upper stone from the cobbles below (Cat no 22). Other examples came from the rubble deposit overlying the northwest central floor space (Cat no 14) and from the post-abandonment deposit filling the house scoop. A considerable range of polished stones and enigmatic pebbles and cobbles with pecked depressions (Cool, Section 8.2) was recovered from the same range of 


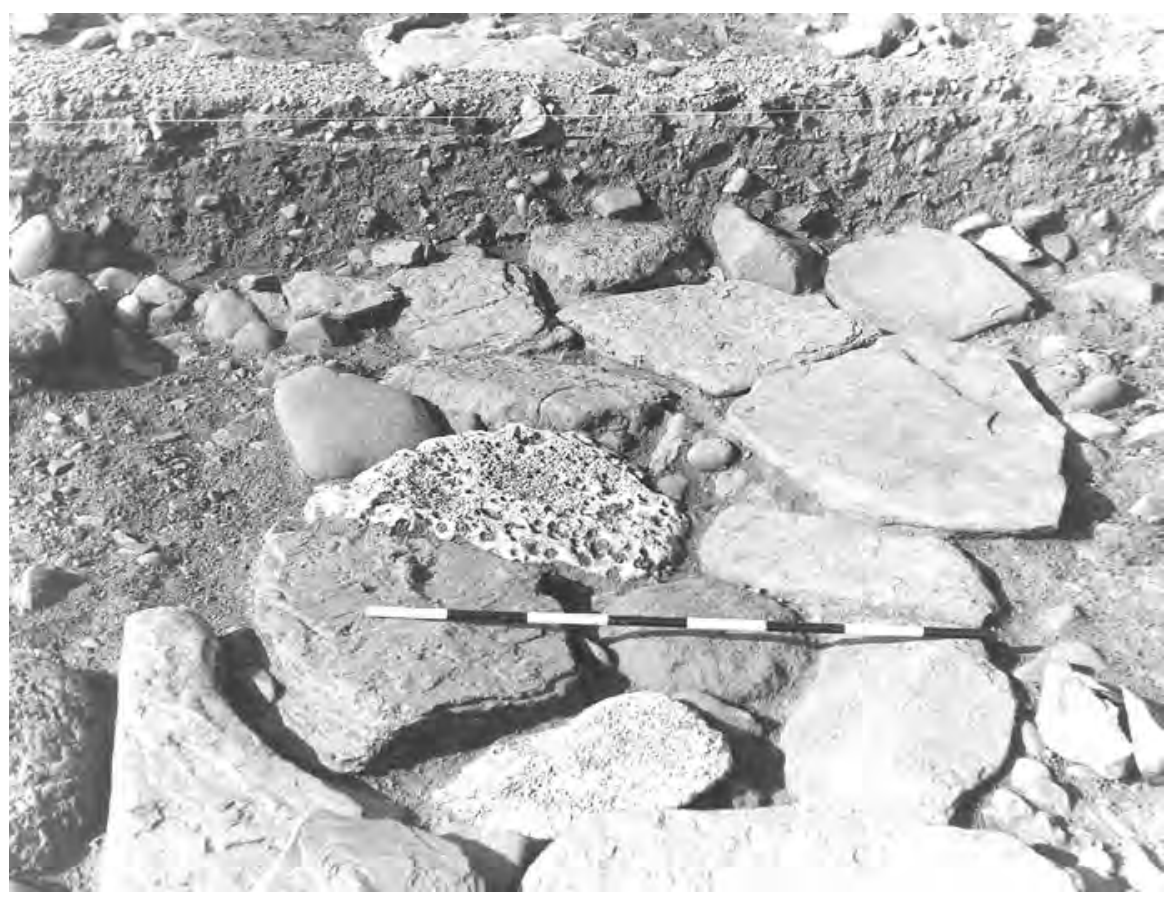

Illus 45 House 2; detail of paving sealed beneath abandonment deposits

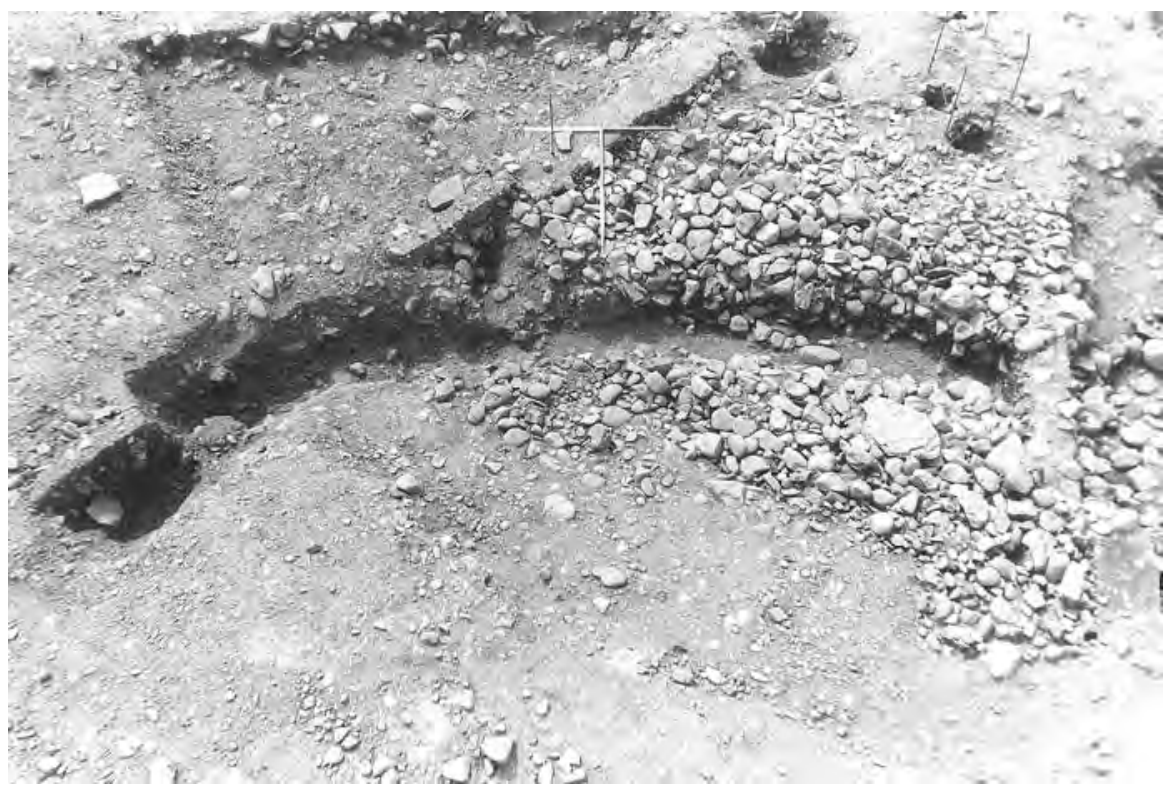

Illus 46 House 2; the late curving ditched feature cutting through the cobble fill of the ring-ditch; from north-west

contexts. A cannel coal bangle roughout was found in the fill of a post-hole in the central floor space (SF 842; Hunter, Section 8.6).

Other types of artefact were less well represented. A few sherds of pottery were recovered, all from the post-abandonment soil infilling the scoop (Cat nos $36-40$ ) or hillwash overlying the outer enclosure palisade immediately to the east of House 2 (this deposit is visible in the foreground on illus 41). Two pieces of iron slag were recovered from the cobble fill of the ring-ditch, and a third was recovered from the central floor area (Section 8.7). A copper alloy rod fragment was derived from the post-abandonment infill of the scoop, and a penannular hoop was found in the hillwash (SF $96 \&$ 97, Section 8.3; illus 61 for SF 97). Almost 20 chipped stone items from the post-abandonment infill of the scoop appear to be residual, as no items were found stratified within the House 2 floor and foundation deposits. Conversely, modern glass and pottery recovered from the same context must have been contaminants introduced by ploughing. 
Reconstruction The remains of House 2 were presented in the interim account (Triscott 1982, 120) as a structural form which was transitional between the early post-ring and later ring-ditch forms represented at Dryburn Bridge. The stratigraphic evidence allows for a more complex sequence to be proposed, incorporating at least three structural phases (illus 39). It is not possible to link all features conclusively to particular phases and the phase plans summarized on illus 39 thus provide the author's suggested interpretation.

House 2 as first built appears to have been a timber roundhouse with an internal diameter of $c$ 10m (Phase I). Its wall-line was defined by the inner ring-groove, with an internal post-ring forming the principal roof support (see Hill 1982b and Reynolds 1982 for comparanda). Its floor space included a sunken peripheral zone (the ring-ditch), with a level central area to which some of the many negative features relate. Its entrance was $c 2 \mathrm{~m}$ wide and, assuming that the post-hole cut by the outer ringgroove entrance terminal relates to this primary structure, was provided with a projecting porch $c$ $2 \mathrm{~m}$ long. The outer ring-groove could have formed an element of this primary structure although, if so, only if the idea of a projecting porch is rejected. In any case it is not an easy matter to propose a structural function for it. Therefore the basic form and size of this structure bears comparison to Houses 3 and 8 , apart from the different external wall construction and the greater scale of the ring-ditch.

House 2 appears at some stage to have been substantially remodelled (Phase II). The building was increased in diameter to $c 13.2 \mathrm{~m}$, its outer wall-line defined by the outer ring-groove. The scooped features between the two ring-grooves may have been excavated as part of the creation of a level house floor, although it has been suggested (Reynolds 1982, 51) that such features at comparable sites may have been formed through wear rather than by design. The primary ring-ditch was filled in with cobbles up to the level of the central floor space, and partly paved over, partly sealing beneath it the post-ring, which must have been removed by that time. Saddle-querns set within this paved surface to the west may indicate that grain- or food-processing activities took place around the periphery of the structure. However, it could not be established from the site records that the stones had their grinding faces uppermost. In any case, while saddle-querns incorporated into a roughly paved are potentially useable, such a position would have made them uncomfortable to use and it would have been hard to collect any processed material that fell from the stone, suggesting that operation of a quern in this position would have been wasteful and inefficient. This is in contrast to a quern set in an elevated position, where usage would have been less onerous to the operator and falling material could have been collected by receptacles or blankets placed on the floor around the quern (A Jackson, pers comm). As a result of these technical drawbacks the complete lower stones set within the paving are better interpreted as reused material rather than in situ fixtures.

It is not certain if or how this refurbished structure was roofed. The outer wall is unlikely to have provided the only support for what would have been a large roof. It is possible that the remains of a post-ring have remained undetected within the mass of negative features set within the central floor space, although if this were the case then the ratio between post-ring and wall diameters would have been considerably different from Hill's proposed golden ratio (Hill 1984). It seems possible that the roof may have had supports that are not archaeologically detectable, such as posts resting on stone pads. This structure was not provided with a projecting porch.

The enlarged building continued to be modified (Phase III), through the laying of a secondary band of paving over the infilled ring-ditch. Probably during the final stages of the use of the building, but also potentially after its abandonment, a ditched feature reminiscent of a Dalladies-type souterrain was cut through the periphery and wall of the building, into the slight hillslope. The stone features surviving above the subsoil surface in the centre of the building are also likely to belong to the terminal use of the House 2.

The pre-enclosure Period II, Phase III Building 2 at Broxmouth appears to have been a roundhouse very similar in character and date to Dryburn Bridge House 2, displaying many of the same foundation components (Hill 1982b, 13, figure 2a), including concentric ring-grooves, inner post-ring and ring-ditch. Full details of the character and phasing of that structure have yet to be published, although the published interim report (Hill 1982a, 153) indicates that it was larger than the Dryburn Bridge structure, its outer ring-groove defining an area $17 \mathrm{~m}$ in diameter, and that it had been refurbished several times with at least three structural phases.

Stratigraphic and spatial relationships The remains of House 2 did not have any physical relationships with other elements of the settlement, although its juxtaposition with neighbouring features requires scrutiny. Firstly, it is apparent that the wall-line of the building respected the projected approach to House 6 from the south-east, but only in its primary (Phase I) form. It may have been that when House 2 was first built House 6 was standing. By the time House 2 was extended across the approach alignment, House 6 could have been abandoned, although it could alternatively reflect the declining importance of the approach alignment (potentially as a result of the blocking of the putative middle entrance?) and altered access routes through the settlement.

The spatial relationship between House 2 and the adjacent outer enclosure boundary is an interesting one. In its first phase House 2 stood sufficiently 
far from the alignment of the outer enclosure that the two structures could have co-existed. With the enlargement of the building this becomes less clear. The absence of a projecting porch could be explained by the lack of available space between the building and the enclosure boundary. Conversely, the excavators recorded that the palisade packing adjacent to the entrance of the enlarged structure had been worn down, as if by trampling (Triscott 1982, 120 ), which was taken to imply that the enclosure ceased to function during the lifetime of House 2. Using the additional evidence presented here, it is possible to propose that in its first phase House 2 lay within the outer enclosure, but that its enlargement coincided with or followed the dismantling of the outer enclosure, at least in this sector. However, there is no convincing evidence either way in this regard.

Radiocarbon dates Four samples of wood charcoal from House 2 contexts were submitted $c$ 1980 for radiocarbon dating. All samples derived from the charred in situ remains of structural posts. Owing to subsequent concerns over the precision of those dates, additional samples of two surviving posts were submitted to SUERC in 2003 and were dated at the University of Arizona AMS Facility. The results are shown in Table 9 .

Both recently obtained dates encompass the Early Iron Age plateau on the calibration curve ( $c$ 800-400 cal $\mathrm{BC}$ ), and confirm that the original results from the same posts had been broadly accurate. The original dates encompass this period when adjusted errors are taken into account (Ashmore et al 2001), although most have extremely long dates ranges at 2 -sigma, which cover most of the first millennium cal BC.

This renders close dating of the two structural phases of House 2 impossible. Three of the posts appear to pre-date $c 400 \mathrm{cal} \mathrm{BC}$. However, it is not known from where within the oak timbers the sample material was obtained, which could be significant in terms of dating as oak is a long-lived species. The possibility cannot be ruled out that old wood from the Phase I structure was reused in the Phase II building and that the radiocarbon dates AA-53705 and GU-1284 do not accurately date the Phase II construction. GU-1283, from one of the secondary entrance posts, appears statistically more likely to date to an event occurring after 400 cal $\mathrm{BC}$ than before, but the evidence is not strong, especially as the other two dates from the same ring-groove date to before $400 \mathrm{cal} \mathrm{BC}$. The dates reveal nothing as to how long House 2 remained in use.

\subsection{Rectangular structures (illus 47)}

Description Several post-defined rectangular structures were identified during the excavation (illus 3, A-I). These occurred mostly within the southern portion of the outer enclosure, although one example (illus 3, G) occurred further north between Houses 1 and 5, and another (illus 3, I) occurred outside the outer enclosure and adjacent to House 7.

Three examples comprised an arrangement of nine post-holes (illus 3, F, H, I), based on a grid of three rows of three post-settings. These were of similar size, measuring between $3.4 \mathrm{~m}$ by $3 \mathrm{~m}$ (illus $3, \mathrm{H}$ ), and $4 \mathrm{~m}$ by $3.2 \mathrm{~m}$ (illus $3, \mathrm{I}$ ). Four examples were based on foundations of eight posts (illus $3, \mathrm{~A}, \mathrm{~B}, \mathrm{D}, \mathrm{E}$ ). These were of similar dimensions to the nine-post arrangements, ranging from $3.2 \mathrm{~m}$ by $2.7 \mathrm{~m}$ (illus $3, \mathrm{~B}, \mathrm{D}, \mathrm{E}$ ) to $4 \mathrm{~m}$ by $3.6 \mathrm{~m}$ (illus $3, \mathrm{~A}$ ), and were also based on three rows of posts. In one case (illus $3, \mathrm{~B}$ ) the central post was absent, in two (illus $3, \mathrm{~A}, \mathrm{E}$ ) a corner post was missing, and in the last (illus $3, \mathrm{D})$ a central side post was not present. It is not known whether these absences are deliberate structural characteristics or the result of differential survival. For structure A, the position of the missing post is occupied by a pit grave (Burial 12). The six-post structure (illus 3, C) was formed of two rows of three posts, although its size was the same as eight-post structures (illus 3,

Table 9 Radiocarbon dates from House 2. Duplicate sample marked thus * and **

\begin{tabular}{|c|c|c|c|c|c|c|c|c|}
\hline Lab no & Sample context & Material & $\begin{array}{l}\text { Lab } \\
\text { age }\end{array}$ & $\begin{array}{l}\text { Lab } \\
\text { error } \pm \\
\text { 1-sigma }\end{array}$ & $\begin{array}{l}\text { 2-sigma range } \\
\text { using lab } \\
\text { error (cal } \mathrm{BC} \text { ) }\end{array}$ & $\begin{array}{l}\text { Adjusted } \\
\text { error } \pm \\
1 \text {-sigma } \\
\end{array}$ & $\begin{array}{l}\text { 2-sigma range } \\
\text { using adjusted } \\
\text { error (cal } \mathrm{BC} \text { ) }\end{array}$ & $\delta^{13} \mathbf{C}(\%)$ \\
\hline GU-1257* & Outer ring-groove & Quercus & 2450 & 50 & $770-400$ & 110 & $850-200$ & -25.0 \\
\hline $\begin{array}{l}\text { AA-53705 } \\
\text { GU-10813* }\end{array}$ & Outer ring-groove & Quercus & 2500 & 40 & $800-410$ & & & -25.8 \\
\hline GU-1283 & $\begin{array}{l}\text { Outer ring-groove } \\
\text { terminal }\end{array}$ & Quercus & 2280 & 55 & $420-210$ & 110 & $800-50$ & -25.0 \\
\hline GU-1284 & $\begin{array}{l}\text { Outer ring-groove } \\
\text { terminal }\end{array}$ & Quercus & 2615 & 55 & $910-540$ & 110 & $1000-400$ & -26.3 \\
\hline GU-1287** & $\begin{array}{l}\text { Inner ring-groove } \\
\text { terminal }\end{array}$ & Quercus & 2550 & 55 & $830-410$ & 110 & $900-400$ & -25.0 \\
\hline $\begin{array}{l}\text { AA-53703** } \\
\text { GU-10811 }\end{array}$ & $\begin{array}{l}\text { Inner ring-groove } \\
\text { terminal }\end{array}$ & Quercus & 2455 & 40 & $770-400$ & & & -25.1 \\
\hline
\end{tabular}




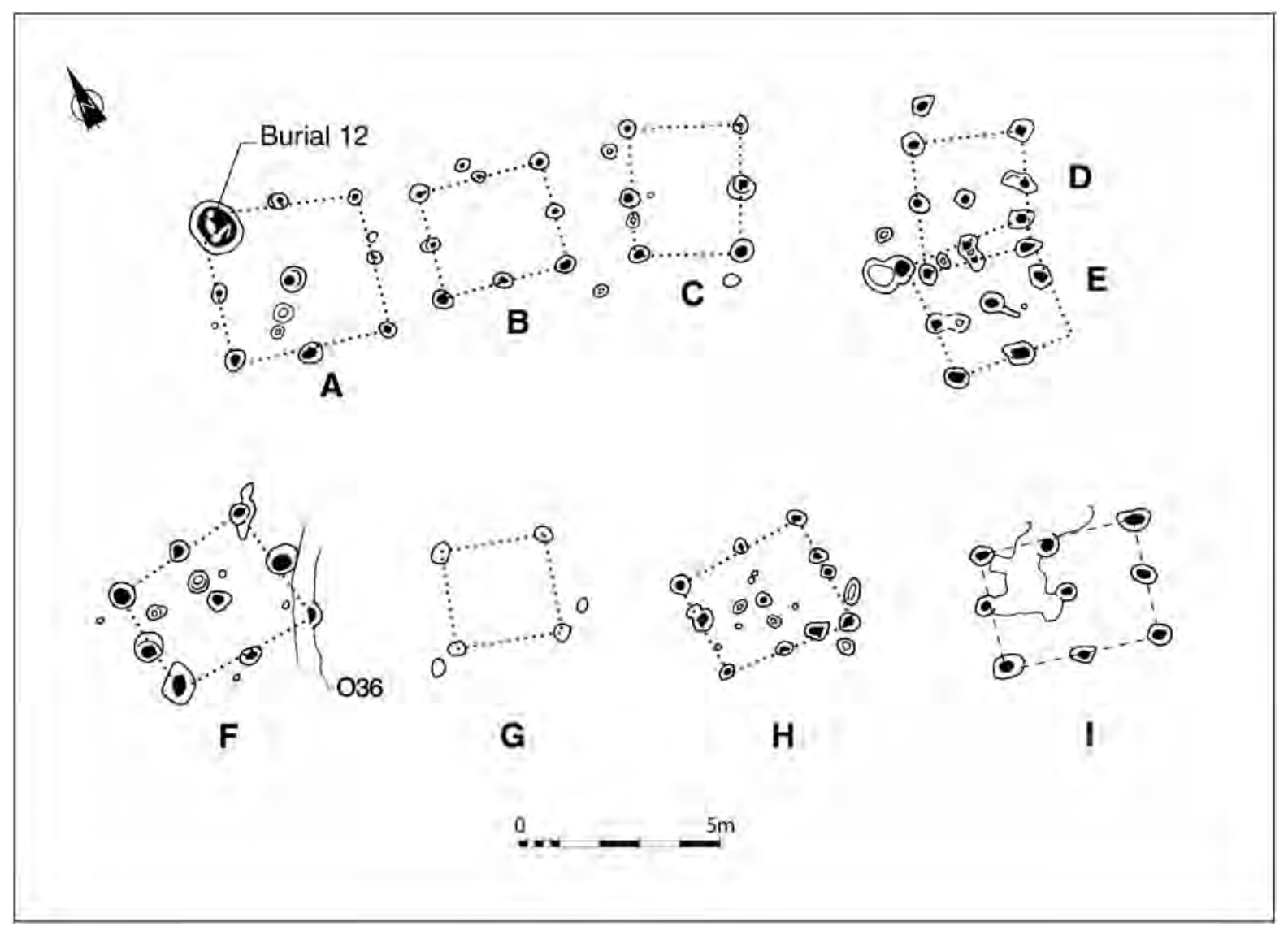

Illus 47 Rectangular structures

B, D and E). The four-post structure (illus 3, G) was smaller than the rest, measuring $c 2.6 \mathrm{~m}$ square.

The post-holes defining the structures were generally preserved $0.3-0.5 \mathrm{~m}$ in surface width and $0.1-0.25 \mathrm{~m}$ deep. The long axes of the structures tended to be orientated broadly east/west, although two examples were aligned north-east/south-west (illus 3, C, D).

It is possible that sub-rectangular arrangements of post-holes elsewhere across the site may have been the remains of comparable four and six post structures, but in areas where scatters of unstratified pits and post-holes exist there is a danger of 'joining the dots' to create structures where none existed. Only the more convincing structures have been presented here, but this may underestimate the number of rectangular structures that have occupied the site.

Artefacts were restricted to pottery recovered from two of the eastern posts of Structure C (L69 and L70, Cat nos 1-8 and 69; illus 58 for Cat nos 1-3) and the north-west corner post of Structure D (F4; Cat no 60). Pottery from vessel Cat no 1 was found in both posts L69 and L70, as well as from the fill of the outer enclosure palisade trench nearby. There were no deposits associated with the structures, and no material suitable for radiocarbon dating was recovered.
Reconstruction Little can be said of the form of the rectangular structures, and any reconstruction is largely determined by the perceived function of the building. Similar rectangular structures, predominantly founded on four or six posts, occurring in Iron Age settlement contexts, have generally been interpreted as raised granaries, based largely upon interpretation (Bersu 1940) of such structures at Little Woodbury (Ellison \& Drewett 1971, 185), but without any positive archaeological evidence in support. Alternative interpretations advanced at various times have included buildings and workshops, animal pens, watchtowers or fighting platforms, raised granaries, shrines, scaffold burials or exposure platforms, and also the porches of roundhouses of which no other archaeological trace survives (Ellison \& Drewett 1971; Guilbert 1975; Guilbert 1981; Kendrick 1995, 64 ). These options could entail the presence of raised buildings, raised platforms or ground-level structures. At Dryburn Bridge the more complex features, particularly those nine-post examples with a central post, tend to suggest heavy load-bearing structures, which supports their reconstruction as erections with raised floors.

Stratigraphic and spatial relationships A small number of stratigraphic relationships were observed between rectangular structures and other 
features. Most strikingly, structures D and E overlapped on slightly different alignments. They could not have stood simultaneously, and although it is not certainly known in which order the two were erected, structure $\mathrm{E}$ lies on the same alignment as $\mathrm{A}-\mathrm{C}$ and might have formed part of a contemporary group. Structure F was truncated by linear palisade trench O36 (illus 3, g), although as this latter feature is ill-understood (Section 7.7.7), the meaning of the stratigraphic relationship is difficult to interpret. Conversely, Structure I and House 7 cannot have co-existed, and while determination of the stratigraphic relationship would have been important, it could not be established during excavation. The putative House 10 and Structure $\mathrm{H}$ could not have coexisted.

The distribution of the rectangular structures across the area for the most part does not form any coherent pattern. The structures do not cluster in any particular sector of the site, and are not spatially discrete from the roundhouses (unlike the Phase II layout of Moel y Gaer, Wales; Guilbert 1975). The exception is the rough alignment followed by structures A, B and $\mathrm{C}$ (and possibly also $\mathrm{E}$ ), which form a row but lay on slightly different alignments from each other. As A-C form an asymmetrical ground plan they have been interpreted as the remains of three separate buildings as opposed to one composite structure (cf Guilbert 1976, 310), although this reasoning is far from incontrovertible. The north-east frontage of structures A-C roughly respects the alignment of the projected approach to House 6 , although structure $\mathrm{C}$ does project a little across the projected alignment between the southern side of the House 6 entrance and the south side of the putative blocked entrance of the outer enclosure. Nevertheless, this juxtaposition tends to suggest co-existence between the two elements, but in itself does not indicate any chrono- logical relationship (such as which was built first or whether both were contemporary foundations).

The presence of Structure I outside the outer palisade boundary is noteworthy, but this cannot be used to demonstrate a chronological relationship between the two. The stratigraphic relationship between Burial 12 and structure A is similarly indemonstrable (cf Triscott 1982, 122, who postulated Burial 12 as secondary), as it is not known whether the burial had truncated an earlier corner-post of structure A or whether the corner-post had been inserted into the earlier burial but all traces had been removed by subsequent plough-truncation. It seems unlikely that the two were contemporary (which would require that Structure A had never possessed a north-west corner post). Whatever the true relationship the positioning of the grave at this location appears a highly significant one.

\subsection{Pit graves (illus 48; illus 49; illus 50; illus 51; illus 52)}

Description Ten inhumations in pits were located, forming a distinctive spatial pattern (for a summary of key characteristics see Table 10). From the west central interior of the enclosure, a line of four graves was traced running north (B6, B8, B9, B2), with a fifth example (B3) located adjacent to B2 possibly forming part of this arrangement. Further to the north, four graves were identified along the outer palisade alignment around the north-west corner of the enclosure (B13, B14, B1, B7). An isolated example (B12) was discovered in the east central portion of the enclosure, to the east of the entrance to House 6 . The graves were relatively widely spaced, being separated by at least $3 \mathrm{~m}$ except for B2 and B3 which lay only $1 \mathrm{~m}$ apart.

Table 10 Principal characteristics of the pit burials

\begin{tabular}{|c|c|c|c|c|c|}
\hline No & $\begin{array}{l}\text { Surface } \\
\text { extent }(\mathrm{m})\end{array}$ & $\begin{array}{l}\text { Pit depth } \\
\text { (m) }\end{array}$ & Orientation & Burial details & Relationships \\
\hline 1 & $1.5 \times 1.0$ & 0.5 & N/S & Left side, flexed, head $\mathrm{N}$, face $\mathrm{E}$ & $\begin{array}{l}\text { Pit cuts across outer enclosure } \\
\text { palisade trench }\end{array}$ \\
\hline 2 & $1.5 \times 1.1$ & 1.0 & N/S & Left side, flexed, head $\mathrm{N}$, face $\mathrm{E}$ & - \\
\hline 3 & $1.6 \times 1.0$ & 0.8 & $\mathrm{~N} / \mathrm{S}$ & Left side, flexed, head N, face E & - \\
\hline 6 & $1.7 \times 1.0$ & $c 1.0$ & $\mathrm{~N} / \mathrm{S}$ & Right side, flexed, head S, face E & - \\
\hline 7 & $1.2 \times 1.1$ & 0.3 & $\mathrm{~N} / \mathrm{S}$ & $?$ & $\begin{array}{l}\text { Lies perpendicular to, and imme- } \\
\text { diately outside, outer enclosure } \\
\text { palisade trench }\end{array}$ \\
\hline 8 & $1.9 \times 1.3$ & 0.7 & N/S & Left side, flexed, head $N$, face $\mathrm{E}$ & Cut by linear feature F2 (illus $3, \mathrm{f}$ ) \\
\hline 9 & $1.9 \times 1.5$ & $c 1.0$ & NE/SW & Left side, flexed, head NE, face SE & - \\
\hline 12 & $1.5 \times 1.2$ & 0.5 & NW/SE & Right side, head NW, face SW & $\begin{array}{l}\text { Occupies position of corner post of } \\
\text { rectangular structure A }\end{array}$ \\
\hline 13 & $1.9 \times 1.5$ & 0.5 & N/S & Right side, flexed, head S, face E & $\begin{array}{l}\text { Immediately outside outer } \\
\text { enclosure palisade trench }\end{array}$ \\
\hline 14 & $1.2 \times 1.0$ & 0.4 & $\mathrm{~N} / \mathrm{S}$ & Head S & $\begin{array}{l}\text { Cuts into outer enclosure palisade } \\
\text { trench }\end{array}$ \\
\hline
\end{tabular}




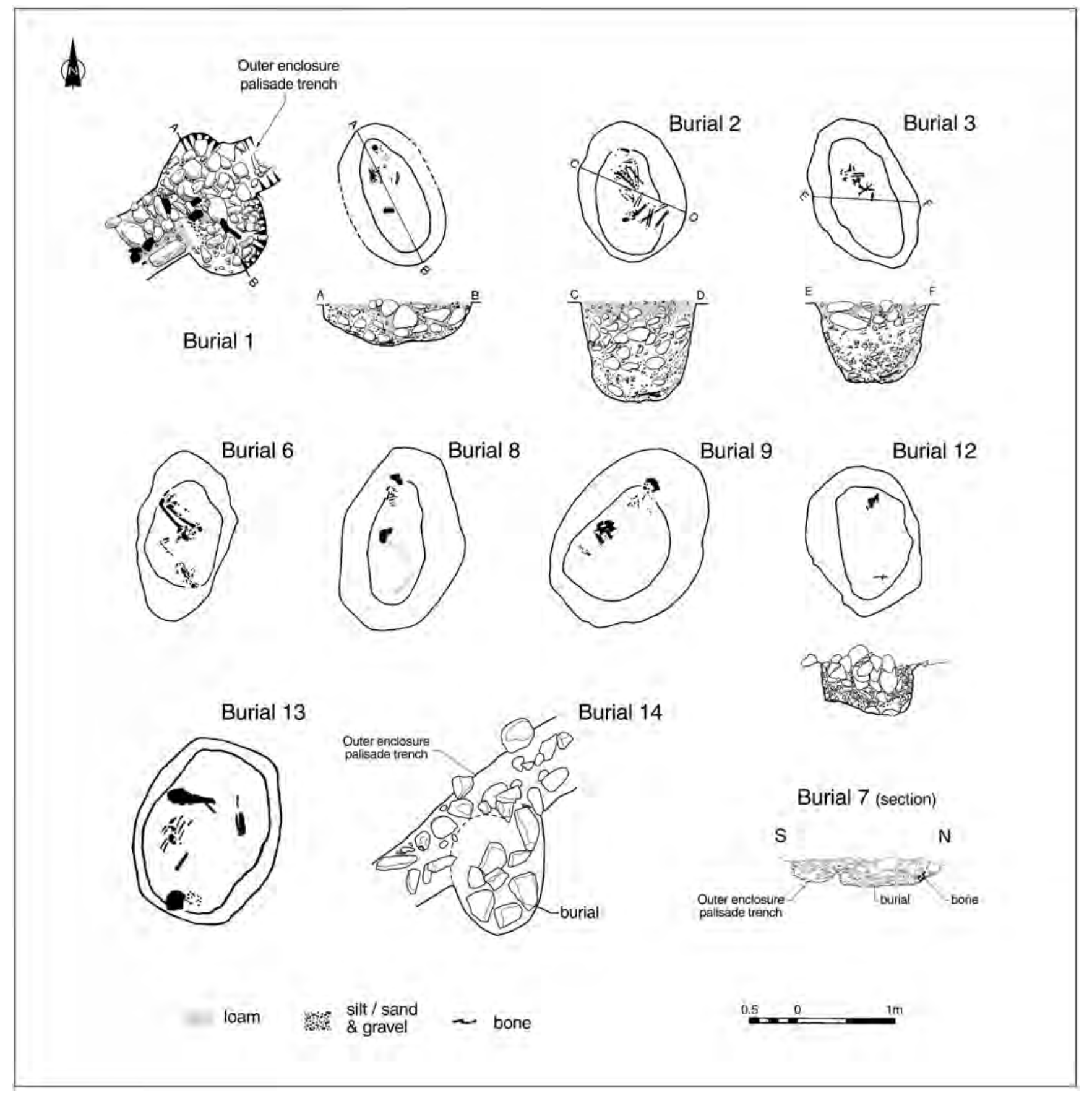

Illus 48 Iron Age pit burials; plans and sections

The grave pits were oval on plan, the smallest (B14) measuring $1.2 \mathrm{~m}$ by $1 \mathrm{~m}$ and the largest (B9, B13) $1.9 \mathrm{~m}$ by $1.5 \mathrm{~m}$. In profile they were steep-sided with a level base, and varied in surviving depth from as little as $0.3 \mathrm{~m}$ (B7) to $1 \mathrm{~m}$ (B2).

However, the linear group within the enclosure was noticeably more deeply cut $(0.7-1 \mathrm{~m})$ than those strung along the outer palisade $(0.3-0.5 \mathrm{~m}$; illus 49-52). The pits were generally orientated close to north/south.

Each pit contained a single inhumation laid on its base. The condition of the skeletal remains ranged from partial and fragmentary (eg B8, B12, B14) to moderate although incomplete (B2). The individuals in the graves comprised a group of adults (Roberts, Section 9.2). The fragmentary nature of the remains meant that only three could be confidently identified to gender, one female (B2) and two male (B6, B9), although one possible male (B12) and two possible females (B13, B14) were also present. Where bone preservation was sufficient for orientation and posture to be distinguished, the bodies had been laid in a flexed position, the majority resting on their left side (five out of eight) and mainly (five out of eight) with the head placed at the northern end of the grave. In all cases where the body was laid on the 
Table 11 Radiocarbon dates from the pit burials

\begin{tabular}{|c|c|c|c|c|c|c|c|c|}
\hline Lab no & Burial & Material & $\begin{array}{l}\text { Lab } \\
\text { age }\end{array}$ & $\begin{array}{l}\text { Lab } \\
\text { error } \pm 1- \\
\text { sigma } \\
\end{array}$ & $\begin{array}{l}\text { 2-sigma range } \\
\text { using lab error } \\
\text { (cal } \mathrm{BC} / \mathrm{AD})\end{array}$ & $\begin{array}{l}\text { Adjusted } \\
\text { error } \pm 1- \\
\text { sigma }\end{array}$ & $\begin{array}{l}\text { 2-sigma range } \\
\text { using adjusted } \\
\text { error (cal } \mathrm{BC} / \mathrm{AD})\end{array}$ & $\delta 13 \mathrm{C}(\%)$ \\
\hline GU-1149 & 1 & $\begin{array}{l}\text { Human bone } \\
\text { fragments }\end{array}$ & 2210 & 70 & $400-110 \mathrm{cal} \mathrm{вс}$ & 110 & $\begin{array}{l}550 \text { cal BC-cal AD } \\
100\end{array}$ & -21.5 \\
\hline $\begin{array}{l}\text { SUERC-4068 } \\
\text { (GU-12237) }\end{array}$ & 1 & $\begin{array}{l}\text { Cranium, rib, } \\
\text { long bone }\end{array}$ & 2485 & 35 & $790-410 \mathrm{cal} \mathrm{вС}$ & & & -20.4 \\
\hline GU-1404 & 2 & Tibiae & 2400 & 100 & $850-200 \mathrm{cal} \mathrm{BC}$ & 140 & $850-150 \mathrm{cal} \mathrm{BC}$ & -21.8 \\
\hline $\begin{array}{l}\text { SUERC-4069 } \\
\text { (GU-12238) }\end{array}$ & 2 & $\begin{array}{l}\text { Fragments of } \\
\text { R Humerus, L } \\
\text { Radius }\end{array}$ & 2435 & 35 & $770-400 \mathrm{cal} \mathrm{BC}$ & & & -21.1 \\
\hline GU-1405 & 3 & Assorted & 2665 & 165 & $1300-350 \mathrm{cal} \mathrm{BC}$ & 230 & $1500-200 \mathrm{cal} \mathrm{BC}$ & -20.4 \\
\hline $\begin{array}{l}\text { SUERC-4070 } \\
(\text { GU-12239) }\end{array}$ & 3 & $\begin{array}{l}\text { Ulna, long } \\
\text { bone, vertebra }\end{array}$ & 2455 & 35 & $770-400$ cal вс & & & -20.6 \\
\hline GU-1410 & 6 & Femur & 2415 & 80 & $790-390 \mathrm{cal} \mathrm{вС}$ & 110 & 800-200 cal BC & -20.9 \\
\hline $\begin{array}{l}\text { SUERC-4073 } \\
\text { (GU-12242) }\end{array}$ & 6 & Femur & 2380 & 35 & $760-380$ cal вс & & & -21.7 \\
\hline $\begin{array}{l}\text { SUERC-4084 } \\
(\text { GU-12253) }\end{array}$ & 6 & R Femur & 2400 & 35 & $760-390 \mathrm{cal} \mathrm{вС}$ & & & -21.2 \\
\hline $\begin{array}{l}\text { SUERC-4412 } \\
(\text { GU-12244) }\end{array}$ & 8 & $\begin{array}{l}\text { Long bone } \\
\text { and cranial } \\
\text { fragments }\end{array}$ & 1705 & 40 & cal AD $240-420$ & & & -23.6 \\
\hline GU-1412 & 9 & Femoral head & 2300 & 125 & $800-100 \mathrm{cal} \mathrm{BC}$ & 175 & $\begin{array}{l}800 \text { cal BC-cal } \\
\mathrm{AD} 50\end{array}$ & -21.6 \\
\hline $\begin{array}{l}\text { SUERC-4074 } \\
\text { (GU-12245) }\end{array}$ & 9 & Pubis & 2435 & 35 & $770-400 \mathrm{cal} \mathrm{вС}$ & & & -21.0 \\
\hline GU-1414 & 13 & Leg frags & 2040 & 180 & $550-450 \mathrm{cal} \mathrm{AD}$ & 250 & $\begin{array}{l}800 \text { cal BC-cal AD } \\
600\end{array}$ & -20.8 \\
\hline $\begin{array}{l}\text { SUERC-4088 } \\
\text { (GU-12254) }\end{array}$ & 13 & $\begin{array}{l}\text { Petrous } \\
\text { temporal }\end{array}$ & 2450 & 35 & $770-400$ cal вс & & & -20.8 \\
\hline
\end{tabular}

left side the head was placed to the north, whereas in two of the three cases where the body was laid on its right the head was to the south, the exception being the outlying B12. All the bodies in the west half of the site had thus been interred facing east, and this consideration would seem to have formed an important part of the burial rite.

The burials were sealed beneath stone backfill, apparently placed directly over the bodies (illus 49; illus 50). Because these fills did not represent quarry spoil from the digging of the pits they must have been brought from elsewhere. There was no evidence to suggest how, if at all, the graves had been marked above ground. Plough-truncation would have removed any traces of surface features, particularly unobtrusive features such as low mounds of soil or stones.

The lower molar of a sheep was found in Burial 3 , and indeterminate fragments of bone derived from the fills of Burials 2 and 12. A worn fragment of cannel coal working debris was recovered from Burial 2 (Section 8.6, SF 220), and a worked stone was found in Burial 12 (Section 8.2, Cat no 37). The cannel coal debris derived from an upper fill and is unlikely to have been a deliberate introduction to the grave. It has not been possible to establish the precise contexts of recovery of the molar and worked stone, and it is therefore not known whether they represent deliberate or accidental introductions.

Stratigraphic relationships In several cases the graves had important relationships with other structural elements. All four graves identified along the outer enclosure boundary appear to have been dug after the palisade was constructed. Two (B7, B13) had been excavated immediately outside the alignment of the palisade trench (illus 50; illus 51), their positions surely guided by its presence. B1 had been cut directly across the line of the palisade trench (illus 49), an event that probably occurred after the removal of the palisade. B14 clipped the edge of the palisade trench (illus 52), and could have been excavated either when the stockade was upstanding or after its removal. The latter interpretation seems more likely due to the destabilizing effect the cutting of the grave pit would have had on the palisade through the disturbance of its foundation packing. Elsewhere, B8 was clipped on its north side by a curvilinear ditch (F2, illus $3, \mathrm{f}$ ), and this latter feature was in turn cut by the porch of House 3 . Thus, in most cases the interments post-dated the 


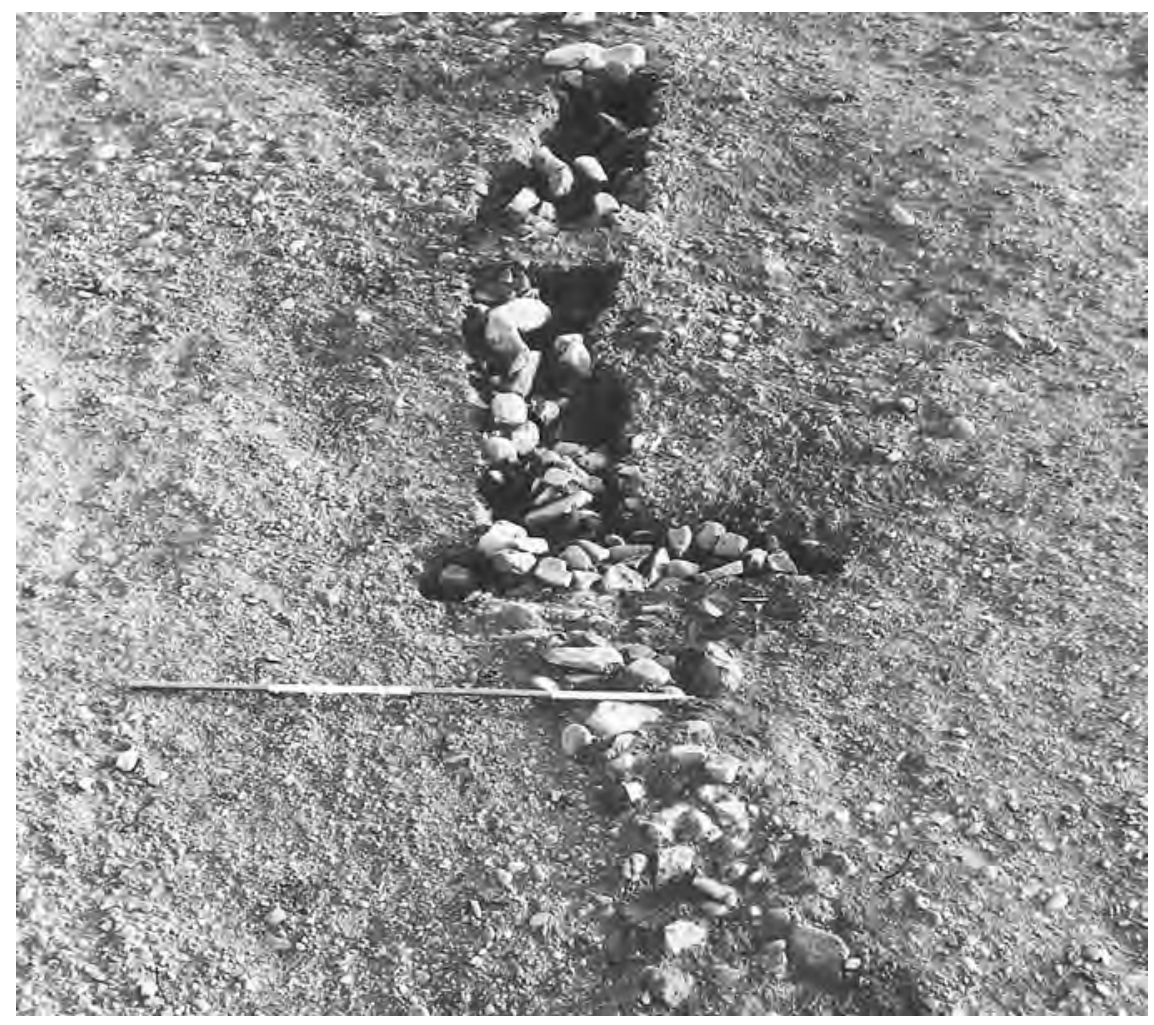

Illus 49 Burial 1; cut across partly excavated outer enclosure palisade; from south-west

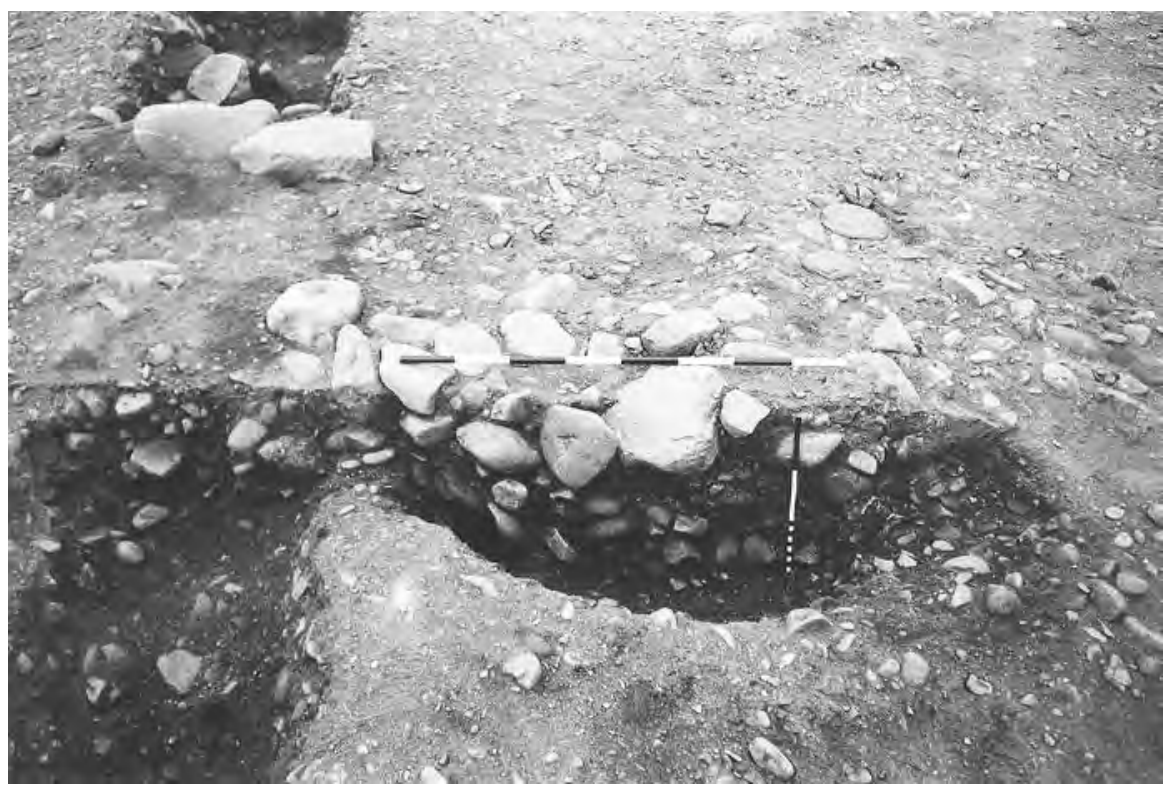

Illus 50 Burial 7 and palisade trench; half-section; with partly excavated outer enclosure palisade trench to left (south)

outer palisade trench but B8, uniquely, pre-dated at least two constructional phases.

Radiocarbon dates Samples of human bone from six pit graves were submitted to Glasgow University for radiocarbon dating in 1980 . Owing to concerns over the precision of these dates, and through a desire to date as many elements of the site as possible, additional samples from seven graves were submitted for dating to SUERC (see Section 2.2.3 for discussion of the rejection of an intermediate set of dates). All results returned are collated in Table 11, with calibrations obtained by SUERC using OxCal v 3.5 (Bronk Ramsey 2000).

Due to the substantial errors attached, most of the original determinations are largely unrewarding, 


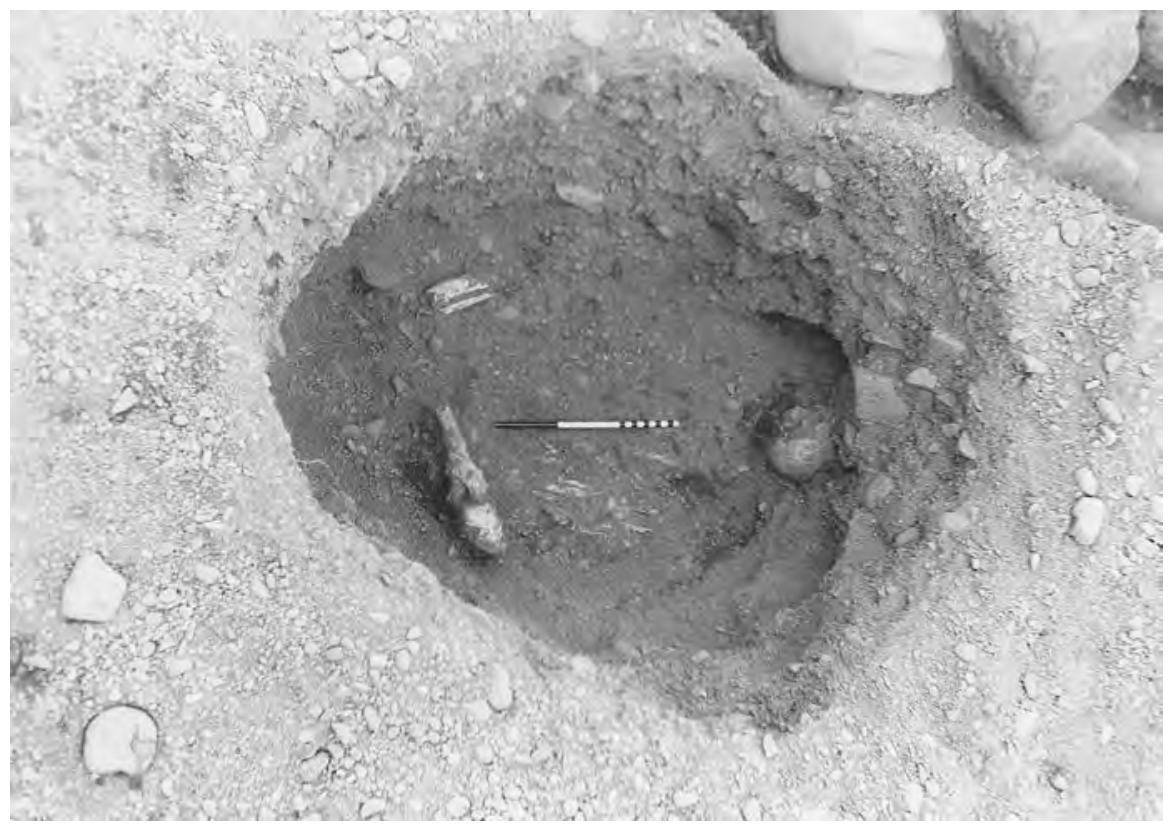

Illus 51 Burial 13; showing preserved human remains; with outer enclosure palisade packing partially visible top right

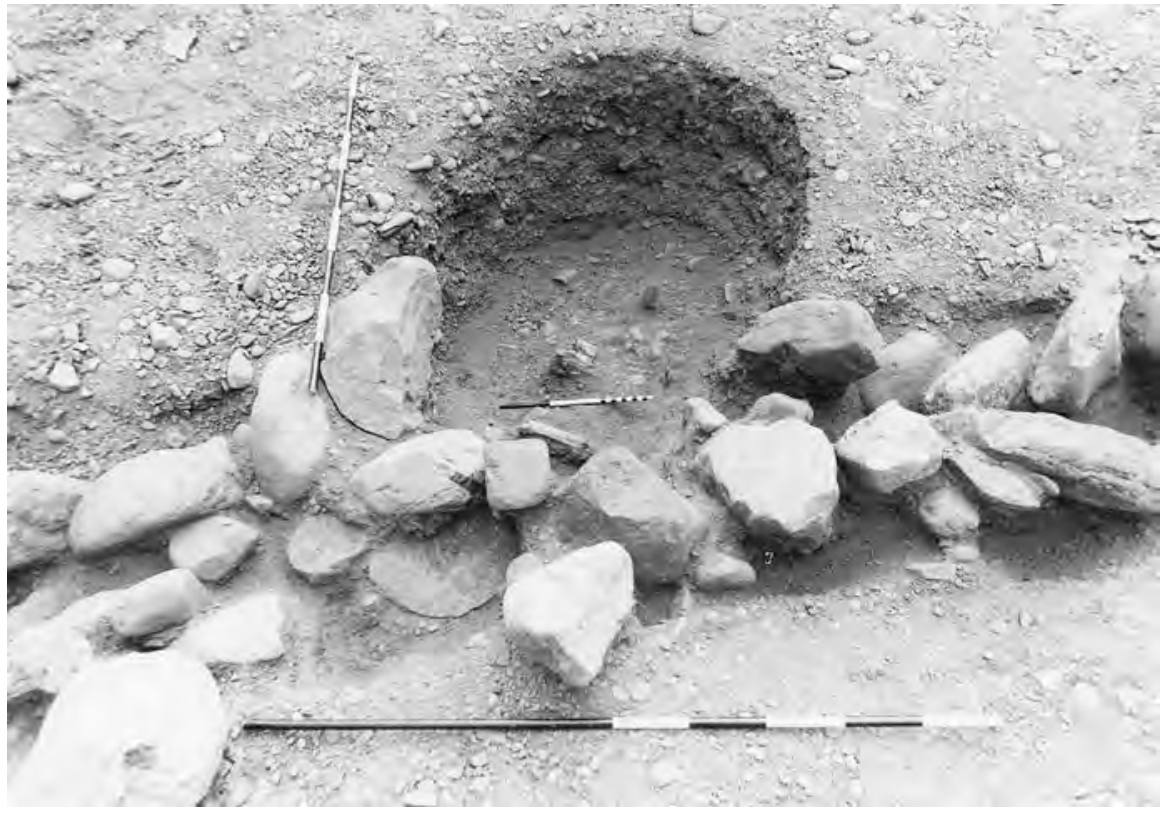

Illus 52 Burial 14; truncating outer enclosure palisade (with packing left in situ); from north-west

using the adjusted ranges the best being a wide range of 550 cal BC to cal AD 100 for Burial 1 (GU-1149). The recent dates have provided narrower ranges that in most case fall within the wide ranges provided by the initial dates.

With one exception the recent set of dates are consistent, and indicate that the individuals buried within Burials 1, 2, 3, 6, 9 and 13 lie within the period $800-400 \mathrm{cal} \mathrm{BC}$. This wide range reflects the flattening of the radiocarbon calibration at this period, and is not capable of tightening. As a result it is not possible to use the radiocarbon dates to estimate the length of time that the cemetery was in use, or to attempt to chart where the origins of the cemetery lay and how it expanded spatially over time.

The date obtained from Burial 8 (SUERC-4412) is radically different from the others, with a calibrated age range spanning the early third to early fifth centuries cal $\mathrm{AD}$ and a $\delta^{13} \mathrm{C}$ value at variance with other dated samples (and also a $\delta^{13} \mathrm{C}$ value obtained from a different bone from the same burial, Section 9.3, Table 18). However, the grave is of very similar character to the others, and had been cut by later phases of Iron Age settlement 


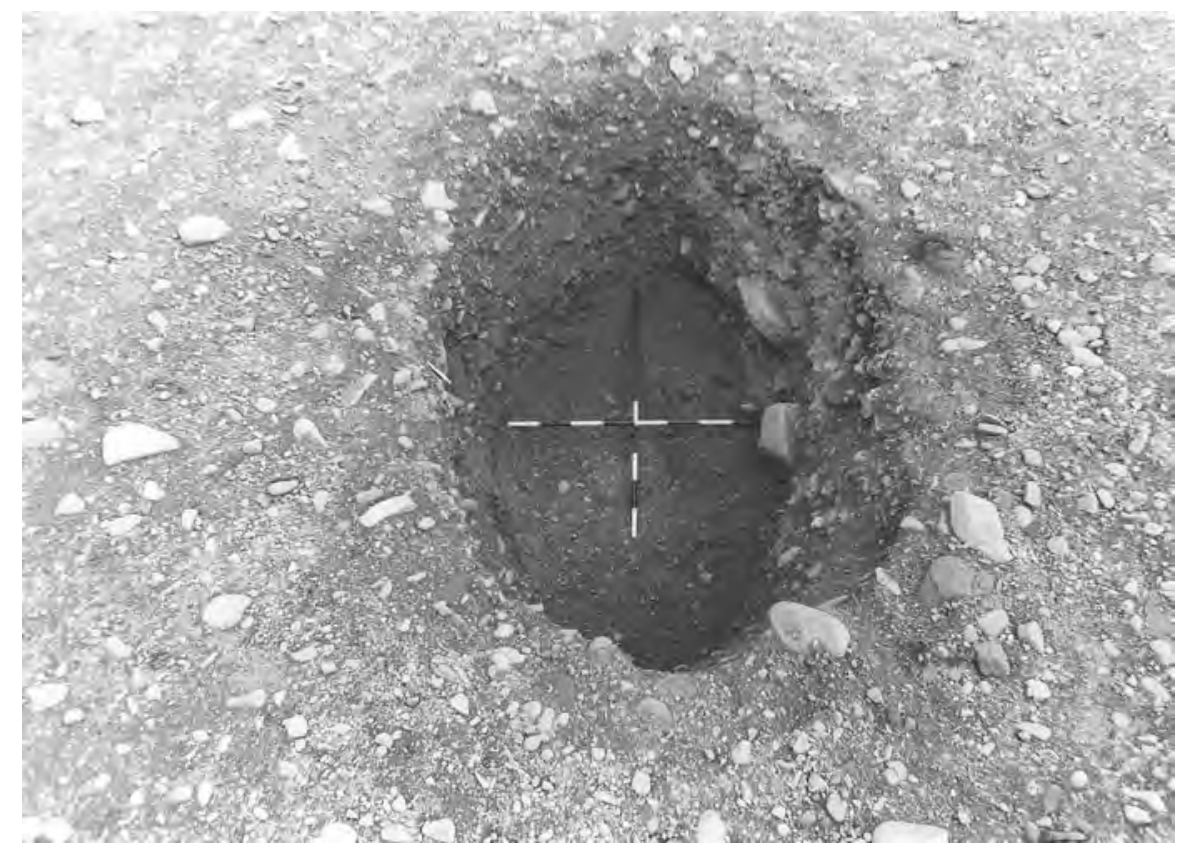

Illus 53 One of the large pits to west of Houses 7 and 8

activity. For these reasons, and because there are no other features or artefactual evidence of comparable date found anywhere else at Dryburn Bridge, it is the author's view that this date is likely unreliable, although the subjectivity of that statement is accepted.

\subsection{Boundary lines (illus 3)}

As discussed in relation to the rectangular structures (Section 7.5), there is a danger in reconstructing boundary lines from scatters of pits and post-holes that the interpretative task of joining the dots will create boundary features that never existed. The opportunities for such excesses at Dryburn Bridge are manifest. Nevertheless, there are certain features that stand out as representing boundary lines of varying character. Other possible alignments do catch the eye, but are considered less credible, although of course their significance may become apparent to future researchers reconsidering the excavation results.

\subsubsection{Fence-line associated with House 7 (illus 3 , a; illus 36)}

The foundation slot of a fence-line (K5) runs around the south and east sides of House 7 . The slot was preserved to $0.5 \mathrm{~m}$ wide by $0.2 \mathrm{~m}$ deep to the southwest, decreasing towards the north-east to $0.3 \mathrm{~m}$ wide by $0.1 \mathrm{~m}$ deep. This feature was interpreted in the interim report (Triscott 1982, 123) as skirting the collapsed remains of House 7. There is, however, no stratigraphic evidence to support such an interpretation, and it is also possible that the feature represents part of an enclosure around the roundhouse during its occupation. Indeed, the fence-line may well have articulated with the entrance passage to House 7 (illus 36). Lumps of iron slag and a hone (coarse stone, Cat No 70, illus 60) were recovered from the fill of the foundation slot.

A mixed sample of charcoal (hazel, birch, willow, alder) from the slot was submitted for radiocarbon dating. Using the adjusted errors proposed previosly (Ashmore et al 2001) a date calibrated at 2-sigma to cal AD 0-600 was returned (GU-1285; $1730 \pm 55$, adjusted to \pm 110 ). Reservations must be attached to the meaning of this date given the taphonomy of the sample, which raises the possibility that the determination represents an average of material of different dates (cf Ashmore 1999).

\subsubsection{Pitted boundaries articulating with House 8 porch (illus 3, b)}

Alignments of closely-spaced pits extended northeast and south-west from the outer end of the entrance to House 8, and may be interpreted as a pitted boundary line associated with this roundhouse. To the north-east it is possible that the pitted boundary turned north-west to abut the south side of House 3 (at pit E1), whereas to the south-west it may have articulated with feature M69 or have turned more sharply to the west (to pit M5). The pits were up to $1.5 \mathrm{~m}$ across in surface dimensions.

Finds from the features of this pitted boundary include pottery from pit E1 (Cat Nos 56-58; see illus 
58 for Cat No 56), and animal bone and an oil shale bead from M1 (SF657, Section 8.6, illus 62).

\subsubsection{Pitted boundary north-west of House 7? (illus 3, c; illus 53)}

At least six large oval pits, attaining over $2 \mathrm{~m}$ in length, $1 \mathrm{~m}$ wide and over $1 \mathrm{~m}$ deep, formed a curvilinear alignment running to the north-west of House 7. They contained sterile sand and gravel fills, possibly deliberate backfill, although the excavator noted that pea grits in their bases suggested that they had been left open for at least a short while. It is possible to interpret these features as components of a pitted boundary comparable to that associated with House 8, and they may even have defined a garden plot around House 7, articulating to the south with fence-line K5. The size and steepsided profiles of the pits might commend them as grave-pits. However, their lack of burial remains, combined with their lack of a common alignment, argues against this.

\subsubsection{Fence-line north of House 9 (illus 3, d; illus 30)}

A $c$ 11m long line of seven pits on a WNW/ESE orientation to the north of House 9 may represent the foundations of a fence-line. Its alignment ran parallel to that of rectangular structures A-C, which lie $c 4 \mathrm{~m}$ away. There were no finds from these pits.

\subsubsection{Fence-line east of House 9 (illus 3, e)}

A sinuous line of shallow post-holes was detected on a north/south alignment. These extended over a length of $c 15 \mathrm{~m}$, terminating at their north end beside rectangular structure $\mathrm{C}$. The alignment trended across the palisade trench of the outer enclosure, in its centre apparently incorporating two lines which ran to either side of the palisade slot and apparently respecting its alignment. There were no stratigraphic links between the post-holes and the palisade slot. Therefore the phasing and structural associations of this fence-line remain uncertain, although it does not appear to have been contemporary with the outer enclosure. There were no finds from the component features of this fence-line.

\subsubsection{Feature F2/F3 (illus 3, f)}

A $c$ 8m long stretch of shallow ditch (F2), c $0.4 \mathrm{~m}$ deep, was located running in a distinct curve northeast/south-west to the south-east of House 3. It had truncated Burial 8 , and was itself cut through by the porch of House 3. An adjacent section of slot (F3) may be related to it. This structure may be no more than the foundation of a windbreak or shelter, as opposed to a fence-line. There were no finds from these features.

\subsubsection{Feature O36 (illus 3, g; illus 47)}

A stone-packed slot, $c 10 \mathrm{~m}$ long by $0.4-0.6 \mathrm{~m}$ wide, ran roughly north/south within the southern interior of the outer enclosure. It appeared to represent the foundation for a length of fence or palisade, although its structural associations are unknown. It intersected the corner of rectangular structure $\mathrm{F}$, and was secondary to it. Pottery (Cat Nos 14-15 \& 68 ) was recovered from this feature.

\subsection{Miscellaneous features of interest}

The southern half of the excavated area contained in places a dense scatter of pits and post-holes, many of which did not have clear structural associations or provide any evidence as to their date or function. Full details of these are lodged with the site archive. However, within this group are a small number of features of notable interest.

\subsubsection{Feature M69 and intercutting remains (illus 54; illus 55)}

Feature M69 represents one of the most complex stratigraphic sequences identified at Dryburn Bridge. It was an elongate pit $c 8 \mathrm{~m}$ long on a northeast/south-west alignment. It measured $1.5 \mathrm{~m}$ wide in the centre, narrowing to $0.8 \mathrm{~m}$ at each end. It had very steep side-walls, shallower ends, particularly at the south-west, and a narrow rounded base, $c 1 \mathrm{~m}$ deep. Its fill comprised a series of cobbles, upright stone slabs and soil fills. The former could have related to internal fitting or partitions, but were not clearly interpretable. Although there was no artefactual or ecofactual evidence to support an interpretation of the function of this feature, it was comparable in terms of its size and profile to the small Dalladies-type souterrains excavated recently at Dubton Farm, Brechin (Cameron 2002).

This feature intersected the boundary of the outer enclosure. Unfortunately the stratigraphic relationships between the two had been obscured, at the north intersection point by the later insertion of a dog burial and at the south by the course of a modern field drain. However, in the latter case, it appears likely that pit M69 had truncated the palisade trench (illus 55). The position of M69 between the fence-line associated with House 7 to the south-west and the pitted boundary associated with House 8 to the north-east raises the possibility that the structure was incorporated into a boundary line associated with those ring-ditch structures.

The dog burial (M43) had been cut into feature 


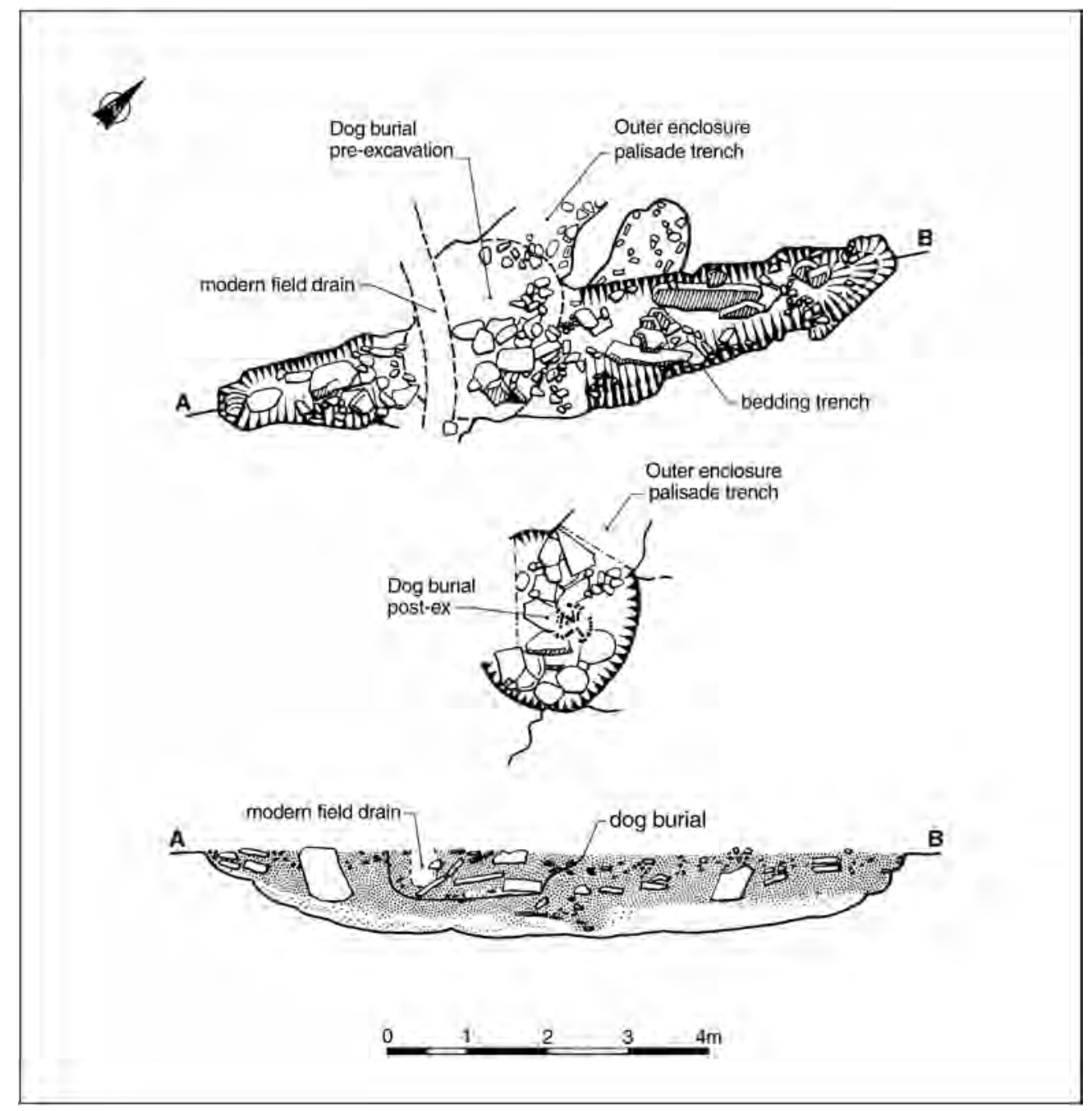

Illus 54 Feature M69 and later dog burial M43; plans and section

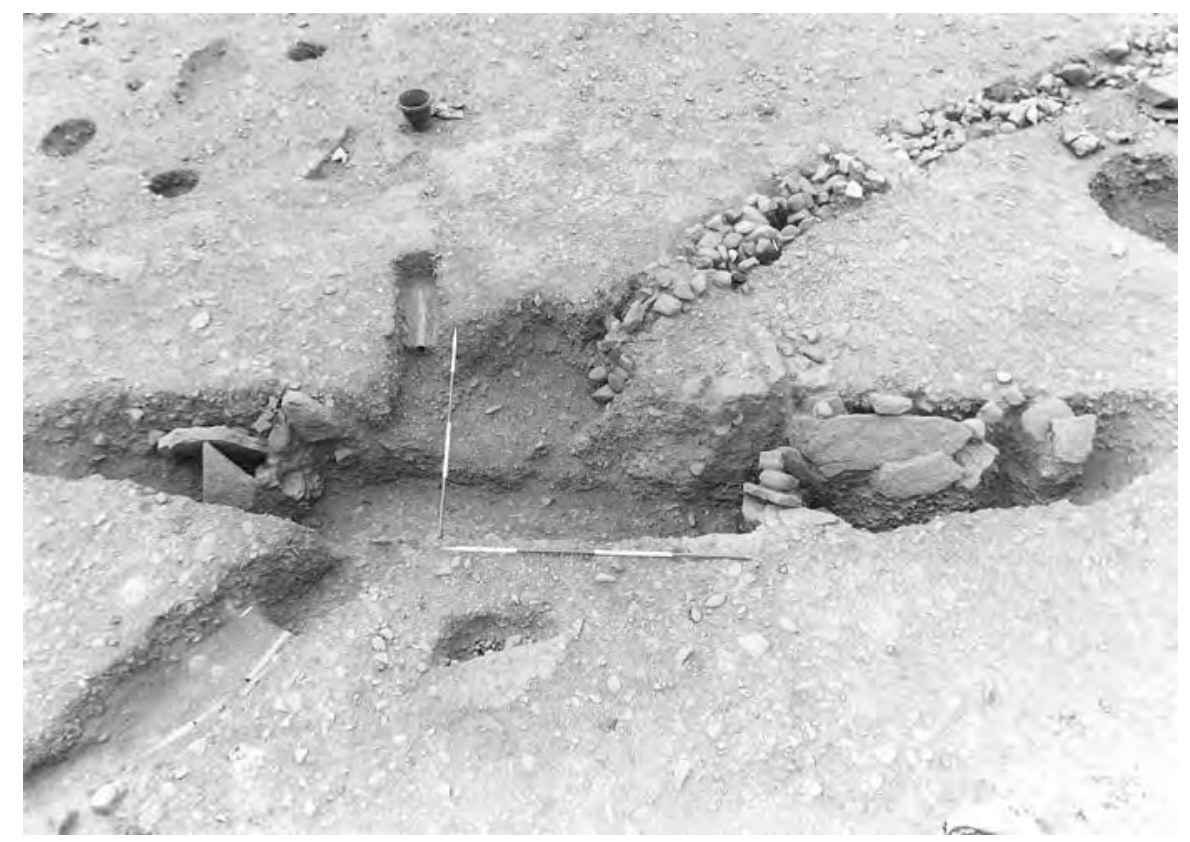

Illus 55 Feature M69; showing excavated profile; from east 


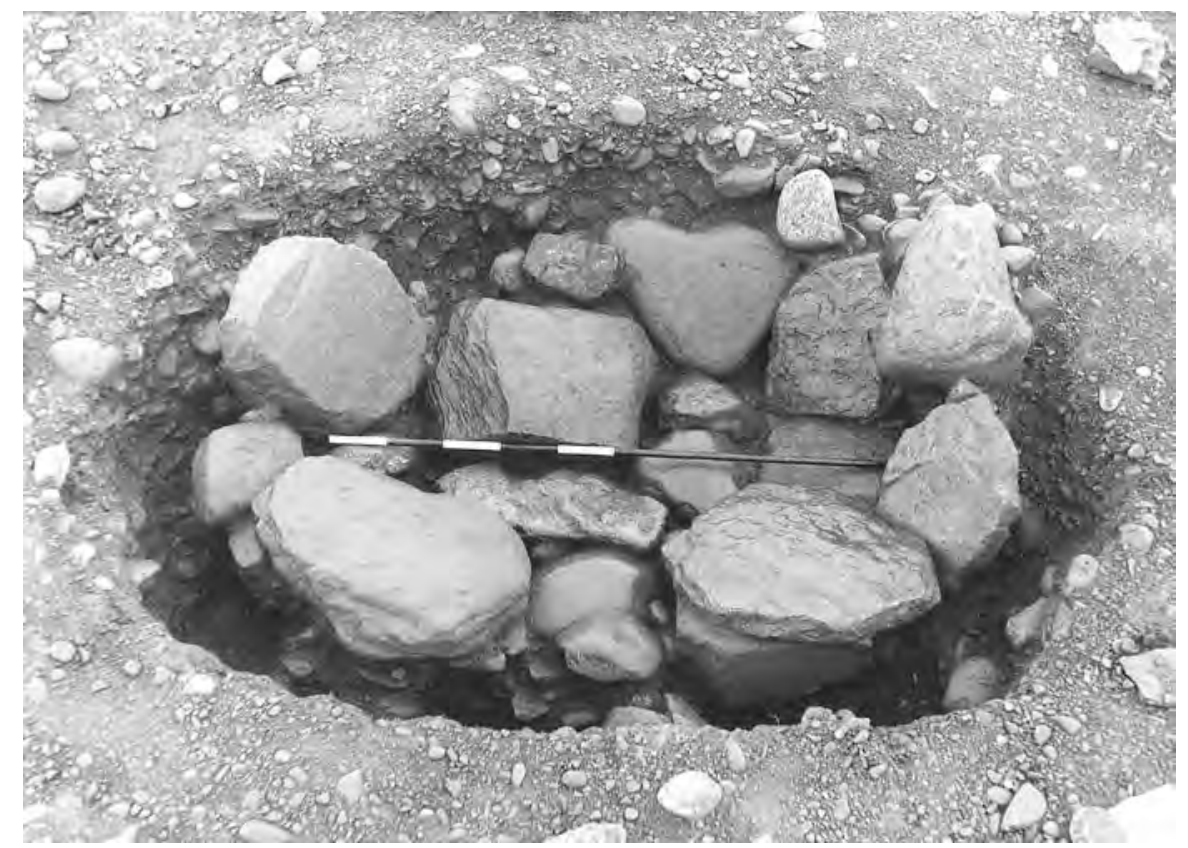

Illus 56 Stone-lined pit M5

M69 after it had been fully filled in. A sub-rectangular pit measuring $2 \mathrm{~m}$ by $1.8 \mathrm{~m}$, and $0.5 \mathrm{~m}$ deep, had been excavated, and the remains of a dog had been placed in the base of the pit on a carefully laid floor of stone slabs. The burial pit had been cut through the palisade slot of the outer enclosure, and was demonstrated to be secondary to it. The dog burial

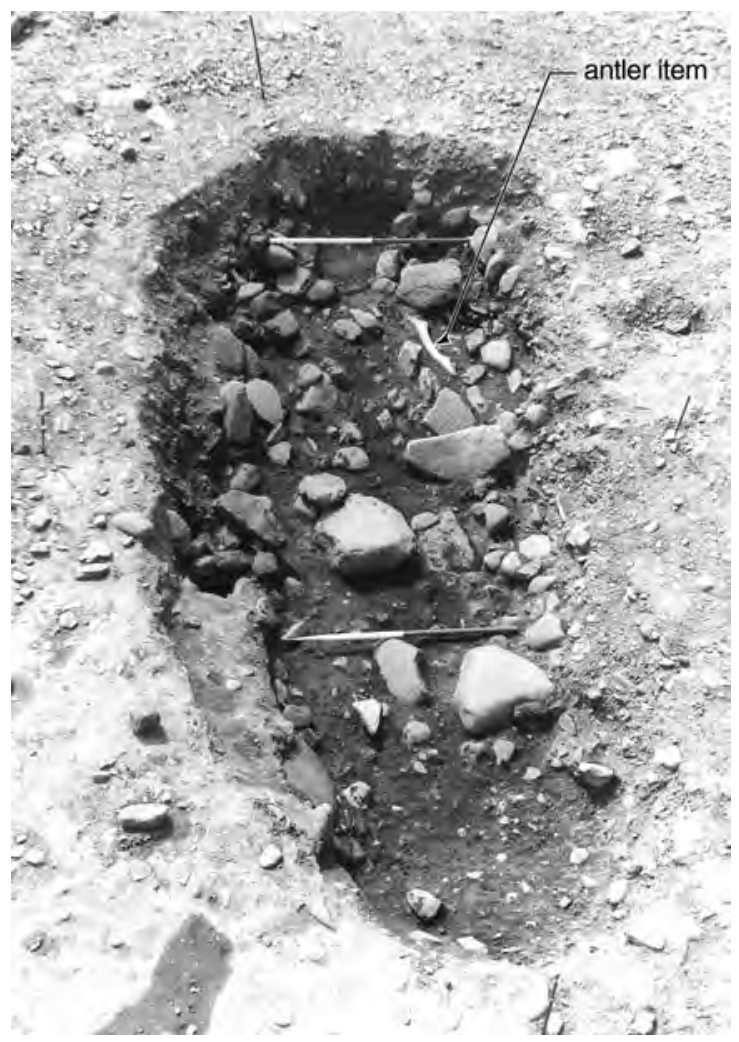

Illus 57 Pit 048 showing partly exposed antler had itself been cut through by the modern land drain.

A significant assemblage of artefacts was recovered from the fill of feature M69 including coarse pottery (Cat Nos 31-35), an iron sickle (SF658, Section 8.4, illus 62), a sherd of Roman glass (Section 8.5, illus 62), an oil shale bangle fragment (SF681, Section 8.6, illus 62 ), and a collection of chipped stone pieces including five microliths. A sherd of pottery was also recovered from the filling of the dog burial (Cat No 62).

A vertebra from the inhumed dog was submitted for radiocarbon dating. This produced a result with a 2-sigma calibrated range of cal AD 80-320 (SUERC-4939/GU-12564; 1830 \pm 40 ). This indicates a Roman Iron Age date for the dog burial. This is consistent with the recovery of Roman glass from feature M69.

\subsubsection{Pit M5 (illus 3; illus 56)}

A little to the north of pit M69 was a distinctive deep pit measuring $1.6 \mathrm{~m}$ by $1.2 \mathrm{~m}$. Above basal sandy fills, the pit had been lined with a neat arrangement of slabs. In the absence of any evidence of burning, this slab-lined feature may best be interpreted as a small working hollow (cf Russell-White 1995, 14 for a larger such feature at Wardend of Durris, Aberdeenshire).

While the feature itself was not particularly noteworthy, it contained several bronze sheet fragments, iron tool fragments and bronze artefacts, within the fills sealed beneath the paving. Very few metal items were found at Dryburn Bridge (Sections 8.3 \& 8.4), and thus the concentration from this feature is striking. However, there was nothing to suggest that the pit was in any way associated with the manufacture of metal items. 
This large pit measured $4.5 \mathrm{~m}$ by $2 \mathrm{~m}$ in surface extent, and was $0.6-0.7 \mathrm{~m}$ deep. It contained a sequence of earth and stone fills, but not evidence of in situ structural remains. A considerable range of artefacts came from the pit. These included pottery (Cat No 59), saddle-quern uppers (Cat Nos 16, 20, 25; see illus 59 for Cat No 20), polished stones (Cat Nos 54, 66-67), fuel ash slag, and antler items (the larger piece partly exposed on illus 57), animal bone, and chipped stone including a microlith. This feature was interpreted during the excavation as a rubbish pit and it is admittedly difficult to find a better explanation. This pit appears to have been too steep-sided and deep to have been used as a working hollow.

A sample of the larger antler was submitted for radiocarbon dating. The result returned (SUERC$4938 /$ GU-12562; $2320 \pm 40$ ) has a 2-sigma calibrated range of 490-200 cal BC, but an approximately $80 \%$ likelihood of falling within the range 490-350 cal BC.
This curvilinear section of shallow ditch measured $9 \mathrm{~m}$ long by up to $0.8 \mathrm{~m}$ wide, being nowhere in excess of $0.25 \mathrm{~m}$ deep. As discussed above (Section 7.2.4), it intersects the area of putative House 10, although it is highly unlikely that the two co-existed. Its form on plan bears superficial similarity to the ringditches characterizing Houses 3, 7 and 8. However, in the absence of either paving or associated structural remains, this interpretation can be rejected. On plan the feature also resembles a souterrain, but the depth of this feature, even accounting for plough-truncation, allows such an explanation to be rejected. Similarly, its spatial relationship with fence-line O36 (illus 3, g) might suggest that two combined to form part a paddock within the south end of the outer enclosure, although this also seems unlikely given their differing character. Pottery (Cat No 73, illus 58), a saddle-quern fragment (coarse stone, Cat No 29) and iron slag were discovered in the sandy fill of this feature. 


\section{The Finds from the Iron Age Settlement}

\subsection{Pottery (illus 58) by Hilary Cool} (drafted $c$ 1980)

\subsubsection{Discussion}

The majority of the later prehistoric pottery from Dryburn Bridge consists of undecorated, fairly coarse-gritted sherds. Where the form of the vessel can be reconstructed it appears to have been a flat- bottomed, barrel or bucket-shaped with a simple upright rounded or internally bevelled rim. Although traces of coil manufacture can be seen in the section of some sherds, the pottery is generally well made and, in some cases, carefully finished. Cat Nos 10, $14,22,24,67,70$ and 71 all have a smooth, slightly glossy outer surface which suggests that they were burnished to a greater or lesser extent when in a leather hard condition; in Cat No 63 this burnish-

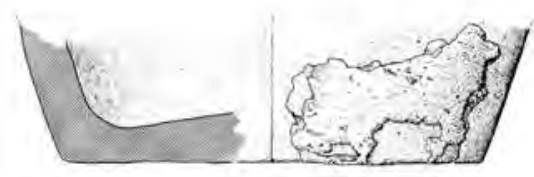

1

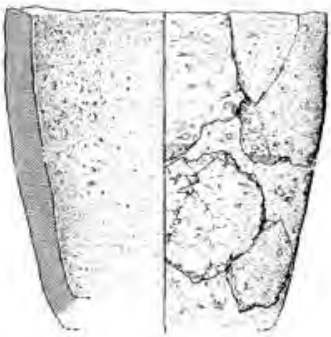

9

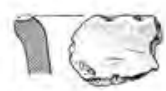

42

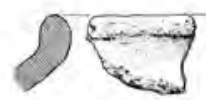

64

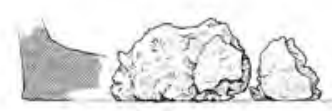

2

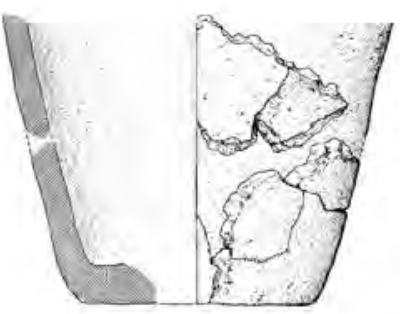

10

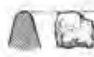

3

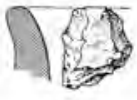

18

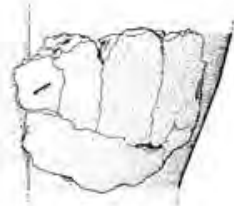

63

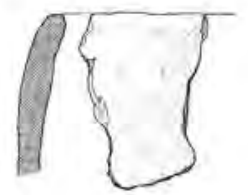

$70 a$

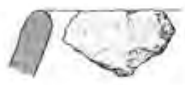

$70 b$

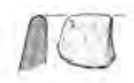

73

Illus 58 Coarse pottery 
ing has brought the surface to a very high gloss. Cat No 1 was burnished and then slipped with a more finely tempered clay than was used in the body of the vessel. These vessels were presumably used for cooking purposes as their inner surfaces are frequently covered by a thick black deposit. (Note by A Dunwell - No dating of organic residues adhering to pottery vessels was undertaken. Should the missing pottery assemblage be re-discovered, this material would appear to have the potential for further analysis and radiocarbon dating.)

The only sherds from Dryburn Bridge that show decoration, or possible decoration, are Cat Nos 20, 42 and 62. Cat No 62 is too small a fragment to identify with certainty and the indentation on Cat No 20 may be accidental. The regular rim-pinching on Cat No 42 is deliberate and the sherd may have come from a vessel similar to those discussed below where the potter had experimented with the rim form.

The undecorated barrel or bucket form, from which the remaining sherds appear to have come, was the dominant pottery class in southern Scotland from at least the Middle Bronze Age to the pre-Roman Iron Age. At the nearby site of Broxmouth (Hill 1982a), it has been possible to identify two consecutive types of pottery belonging to the second half of the first millennium BC (Cool 1982). These two types have been found at other sites too and therefore seem to have been of more than local significance. As Dryburn Bridge and Broxmouth are so close it is to be expected that the Broxmouth pottery types should be recognizable in the Dryburn Bridge assemblage if Dryburn Bridge was in contemporary occupation. At Dryburn Bridge there are no examples of the early Broxmouth Type I pottery and only a very few sherds that could belong to the later Broxmouth Type II. These are Cat Nos 33, 34 and 35 from feature M69/MAY, Cat Nos 36 and possibly 37 from the post-abandonment infill over House 2, possibly Cat No 60 from the north-west corner post of rectilinear structure $\mathrm{D}$, and Cat No 73 from curvilinear ditch $\mathrm{O} 76$.

The occurrence of this pottery in M69 is interesting as not only does it suggest that this feature might be one of the latest features on the site, but it also suggests that Cat No 31, made of a hard thin fabric unparalleled elsewhere in the assemblage, may be of a similar late date as parts of it were found in the same feature.

The fact that the bulk of the plain pottery shows so little correspondence with the Broxmouth material suggests that the Dryburn Bridge pottery belongs to the earlier rather than the later part of the plain bucket class's date range. Pottery of this type, often termed flat-rimmed ware, has been found in contexts dated to the Middle Bronze Age by radiocarbon determinations. Pottery of this type from dated sites at Liddle, South Ronaldsway (Hedges 1975) and Green Knowe, Peeblesshire (Jobey 1980) suggest that the Dryburn Bridge pottery could date from anytime between the mid-second and mid-first millennium BC. Apart from the sherds noted above that have similarities with the Broxmouth Type II pottery, it has not been possible to isolate major differences between the pottery from different contexts. This is in part due to the fact that so many of the sherds are very small and need not indicate that they were all contemporary.

\subsubsection{Catalogue of illustrated forms}

16 body and three base sherds of a large flat-based vessel of possible bucket shape. Fabric thickly tempered with angular dark, red/brown and black and white crystalline grits (up to $10 \mathrm{~mm}$ in length). Traces of coil building visible in section but vessel does not fracture along these lines. Exterior of vessel has a very pale buff slip which has flaked off in places to reveal pink/orange burnished surface. Interior of vessel fired dark grey and covered by thick black encrustation. Exterior surface has a few grass impressions. Base diameter $c$ 160-180mm. Wall thickness $17 \mathrm{~mm}$. Base thickness $c 20 \mathrm{~mm}$. Find nos $\beta$ 547, $\beta$ 607, $\beta$ 610, $\beta$ 623, $\beta$ 820. Contexts: Post-holes belonging to rectangular structure $\mathrm{C}$, and outer enclosure palisade.

22 flat base sherds thickly tempered with angular dark and black and white crystalline grits (up to $10 \mathrm{~mm}$ in length). Fabric fired dark grey in core, buff/red on interior and buff on exterior. Exterior surface smoothed. Length $50 \mathrm{~mm}$. Wall thickness $11 \mathrm{~mm}$. Base thickness $20 \mathrm{~mm}$. Find no $\beta$ 719. Context: Post-hole of rectangular structure C. 31 small rounded rim sherd tempered with 1 grey grit (c 8mm long) and smaller sandy grits (may have been coarsely tempered originally). Fabric fired dark grey in core, buff/orange on surfaces. Length $25 \mathrm{~mm}$. Wall thickness $9 \mathrm{~mm}$. Find no $\beta$ 720. Context: Post-hole of rectangular structure $\mathrm{C}$.

95 rim and approximately 10 body sherds of small, bucket-shaped vessel with upright, internally bevelled rim, in places a slight finger-marked channel on exterior below rim. Fabric thickly tempered with black and white crystalline grits (up to $6 \mathrm{~mm}$ in length). Fabric fired dark grey in core, light grey interior surface and brown on exterior surface. Grits protrude through both surfaces, most noticeably on interior. Rim diameter $c 130 \mathrm{~mm}$. Wall thickness $12 \mathrm{~mm}$. Find nos $\beta$ 605, $\beta$ 606. Context: From the complex of intercutting post-holes at the entrance to House 7.

102 base and 8 body sherds of flat-based possibly bucketshaped vessel. Fabric thickly tempered with dark angular and brown sandy grits (up to $6 \mathrm{~mm}$ in length). Fabric fired grey in interior and brown/buff on exterior. Interior surface has black encrustation, exterior burnished and shows smears in places. Base diameter $c 120 \mathrm{~mm}$. Wall thickness 10mm. Base thickness 16mm. Find nos $\beta$ 611, $\beta$ 612. Context: From the complex of intercutting post-holes at the entrance to House 7.

181 rim sherd - slightly rounded and out-turned. Thickly tempered with angular dark and some black and white crystalline grits (up to $7 \mathrm{~mm}$ in length). Fabric fired buff/grey on surfaces, dark grey in interior. Length $32 \mathrm{~mm}$. Wall thickness $13 \mathrm{~mm}$. Find no $\beta$ 217. Context: southern terminal of the north-east entrance of the outer enclosure.

421 rim sherd - simple rounded rim, edge decorated by oval depressions formed by pinching clay at intervals. Tempered with dark angular grits (up to $5 \mathrm{~mm}$ in length, many smaller). Fabric fired dark grey. Length $36 \mathrm{~mm}$. Wall thickness $10 \mathrm{~mm}$. Find no $\beta$ 110. Context: entrance posthole, House 3. 
561 simple rounded rim sherd tempered with black and white crystalline grits (up to $10 \mathrm{~mm}$ in length, majority smaller). Fabric fired red/buff on surfaces, dark grey in core. Length $30 \mathrm{~mm}$. Find no $\beta$ 104. Context: Pit E1.

636 body sherds tempered with brown and white grits (up to $6 \mathrm{~mm}$ in length). Fabric fired buff brown. Exterior surface burnished to a gloss. Length $70 \mathrm{~mm}$. Wall thickness $8 \mathrm{~mm}$. Find no $\beta$ 613. Context: From unassociated pit to north of House 7.

641 rounded out-turned rim sherd tempered with small sandy and angular grey grits up to $4 \mathrm{~mm}$ in length). Fabric fired dark grey. Length $43 \mathrm{~mm}$. Wall thickness $10 \mathrm{~mm}$. Find no $\beta$ 100. Context: unlocated.

702 rim and 1 body sherds. Rim rounded and possibly inturned. Tempered with brown and white crystalline and grey grits (up to $5 \mathrm{~mm}$ in length). Fabric fired brown/ buff on interior, orange/buff on exterior. Exterior surface slightly burnished, grits project through interior surface. Length (rim) 70mm. Wall thickness $10 \mathrm{~mm}$. Find nos $\beta 504$ and 505. Context: unlocated.
731 rounded rim sherd tempered with sandy grits (up to $20 \mathrm{~mm}$ in length). Fabric fired dark grey throughout. Length $20 \mathrm{~mm}$. Wall thickness $11 \mathrm{~mm}$. Find no $\beta 527$. Context: curvilinear ditch O76.

\subsection{Coarse stone tools (illus 59; illus 60) by Hilary Cool (drafted c 1980)}

\subsubsection{Discussion}

The excavations at Dryburn Bridge produced 31 saddle-querns, of which only ten were complete, unbroken stones. The remainder varied from being only slightly damaged, for example Cat Nos 6 and 18, to being small fragments like Cat No 31. The fragmentary nature of this assemblage is not surprising

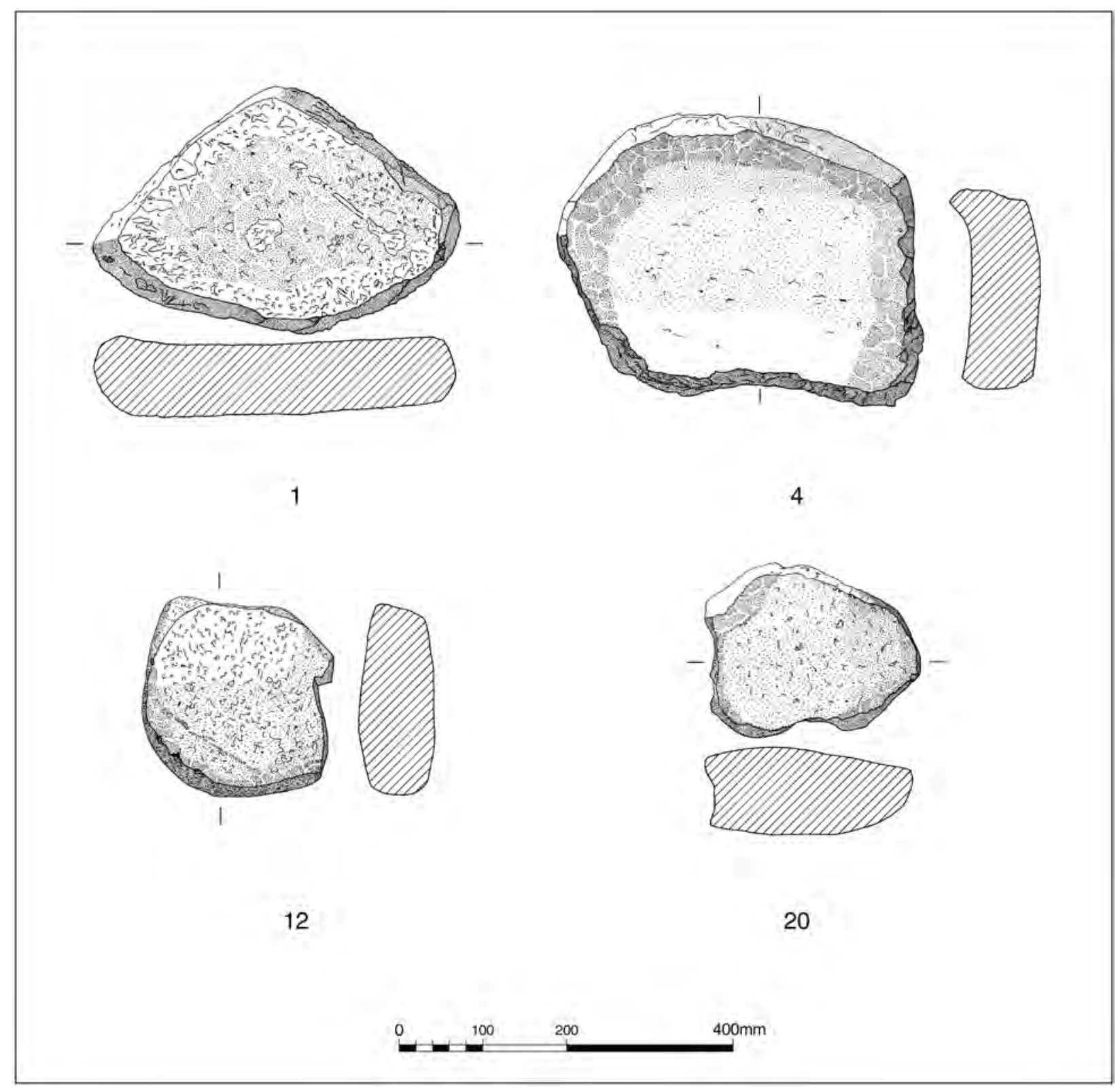

Illus 59 Selected saddle-querns 


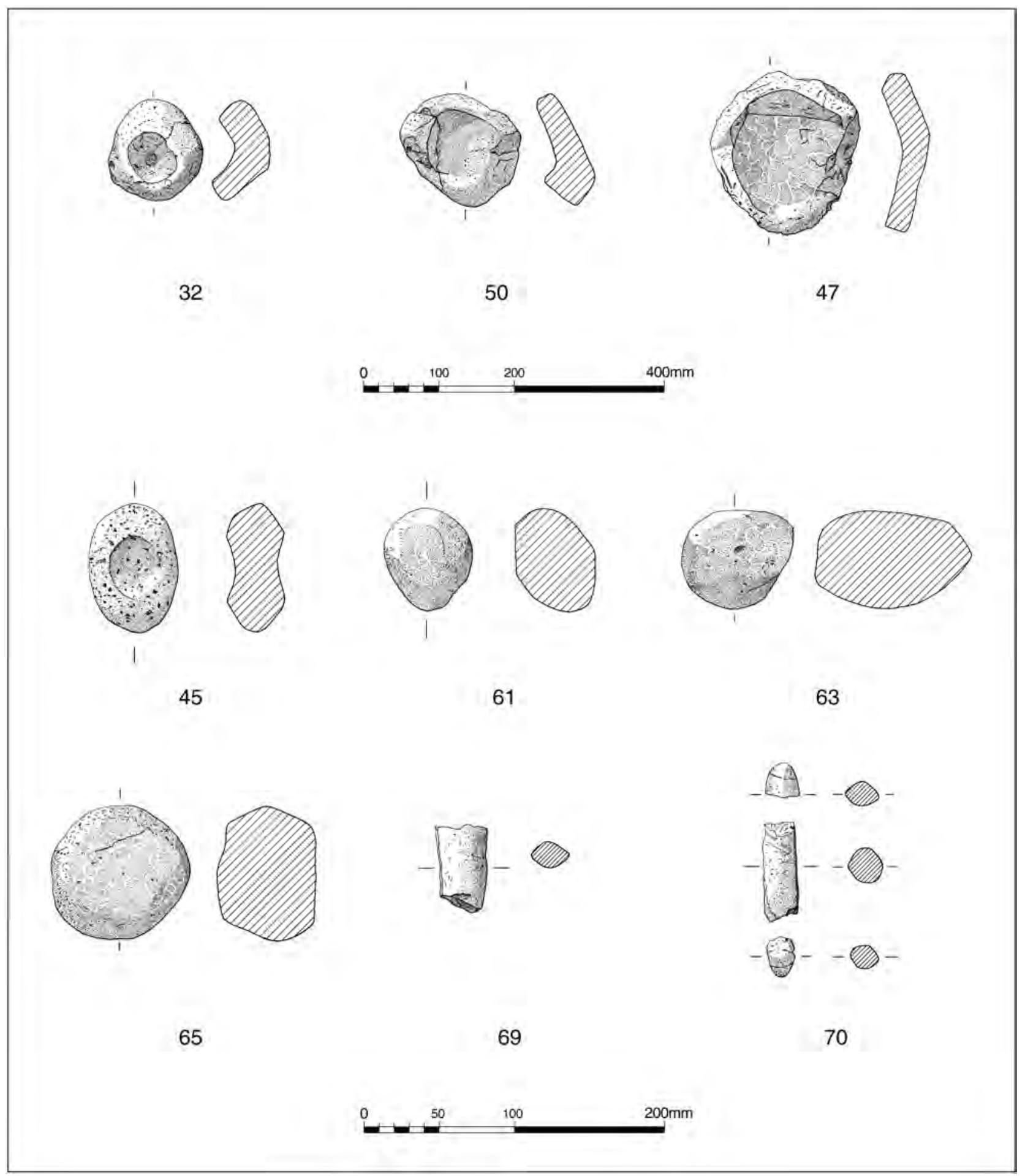

Illus 60 Other coarse stone items

as most of the stones had ceased to be used as quernstones before they reached the contexts in which they were found, and had been reused as paving slabs in the houses or as packing stones in post-holes. The secondary contexts from which the stones were recovered make it impossible to show whether or nor they were all of broadly contemporary date originally. Several of the stones are in very poor condition due to their constituent rock having rotted and crumbled subsequent to their reuse, presumably because of the action of water in the soil and of frost. The assemblage consists of 15 lower stones, ten probable upper stones or mullers and six stones which are too fragmentary to be identified.

The stones were made by splitting a boulder in half to produce a grinding face. The majority of the lower stones and all of the upper stones owe their shape to that of the boulder from which they were made, 
as they show no evidence of having been externally dressed to shape. A boulder of approximately oval outline was usually preferred but triangular (Cat No 5), D-shaped (Cat No 6) and lozenge-shaped (Cat No 18) ones also occur. Three lower stones do appear to have had their lower faces deliberately dressed to shape to a greater or lesser degree (Cat No 1 where a triangular stone has been produced, and Cat Nos 2 and 3 which have an elongated rectangular shape). The grinding faces of most of the stones, both upper and lower, have been dressed with peck marks to roughen the surface so that material may be ground on them more efficiently.

The grinding faces on all the stones are consonant with the edges (that is they extend right up to them). The most common form of grinding face on the lower stones is one that is concave about one axis, though ones that are slightly convex, for example Cat Nos 9 and 11, were also found. Three lower stones, Cat Nos 5, 8 and 12, show a very shallow concavity about the axis at right angles to the axis of the major concavity, but none show a truly dished grinding face. The material ground on these stones, therefore, was not intended to be retained within the grinding face, but to fall away from it and to be collected on a cloth set around the base of the lower stone.

Two main types of wear pattern are visible on the stones. In one the area of greatest wear, taking the form of a high polish and smoothness, is found in an intermittent band all around the edges of the grinding face. This may be seen on Cat Nos 4, 6, 8, 12 and possibly on Cat No 10. In the other pattern, the greatest wear is concentrated at the short ends of the grinding face; it frequently takes the form of an angled slope between the main part of the grinding face and the upper face, in addition to being highly polished. Such wear occurs on Cat Nos 4, 6, 7, and possibly 12 . On similar grounds of size Cat Nos 16 and 18 may confidently be identified as upper stones, as can Cat Nos 19 and 20, though here with less certainty. The concentration of the wear at the short ends of the upper stones was also seen on the upper stones from Douglasmuir, Angus (Kendrick 1995, 58-9). On those stones the wear took the form of a facet between the grinding and upper faces rather than the more gentle slope as here, a difference probably due to the different types of rock used. Although wear in a band around the edges of the grinding face appears to be limited to the lower stones in this assemblage, wear at the short ends is not limited exclusively to the upper stones.

In the case of Cat No 25, the wear is very similar to that seen on the undoubted upper stones, but as it is broken it is not certain that they themselves were upper stones. Small patches of high polish are seen on the short ends of the lower stones Cat Nos 3 and 11 but it is not of the extent or sloped form seen on the upper stones. Therefore, though we may note some exceptions, it does not seem reasonable to conclude that the different wear patterns corre- spond to the use of the stone as either an upper or lower stone.

The remainder of the worked stone assemblage from Dryburn Bridge came from similar contexts to those in which the quernstones were found and much had also been reused. Most of the objects have been only cursorily worked and would best be described as used rather than worked stone. In only a few cases has the original shape of the boulder or pebble been materially altered; these include two hones (Cat Nos 69 and 70).

There are a considerable number of stones that have cups or indentations worked into them (Cat Nos 32-45). The purpose of these cups is not clear, certainly none are large enough to have been used as mortars. The rest of the worked stone assemblage consists of pebbles and boulders that have been used for grinding and polishing. This utilization ranges from Cat No 47 which has a very smooth and carefully made saucer-shaped grinding face, to the patches of polish or wear seen on the hand-held pebbles Cat Nos 61-68 and the boulders Cat Nos 59 and 60.

Table 12 summarizes the contents of the coarse stone assemblage.

Table 12 Summary of coarse stone assemblage

\begin{tabular}{lr}
\hline Saddle-querns and uppers & 31 \\
Hollowed stones & 14 \\
Cobble tools & 23 \\
Hones & 2 \\
\hline
\end{tabular}

\subsubsection{Catalogue of illustrated coarse stone artefacts}

\section{Lower quernstones}

1 Complete triangular stone. Flat lower face and approximately vertical sides have been dressed to shape; grinding face is consonant with edges, slightly concave about short axis and has greatest wear concentrated in centre. Grinding face is chipped in places. Dimensions 440 $\times 300 \times 95 \mathrm{~mm}$. Find no 629 . Context: Paving in ring-ditch, House 7.

4 Complete oval stone. Lower face is natural cortex of boulder. Grinding face is consonant with edges; markedly concave about long axis and shallowly concave about short axis; dressed with peck marks and shows greatest wear as an intermittent band of high polish running around edges and being especially noticeable at shorter ends of stone. Dimensions $470 \times 350 \times 105 \mathrm{~mm}$. Find no 647 . Context: Paving in ring-ditch, House 7.

12 Broken square stone. Lower face is natural cortex of boulder. Grinding face is consonant with edges apart from at one corner, shallowly concave about both axes and dressed with peck marks. Greatest wear is concentrated in a band running around approximately one-third of extant edge. Dimensions $240 \times 220 \times 90 \mathrm{~mm}$. Find no 569 . Context: Fill of inner ring-groove, House 2. 


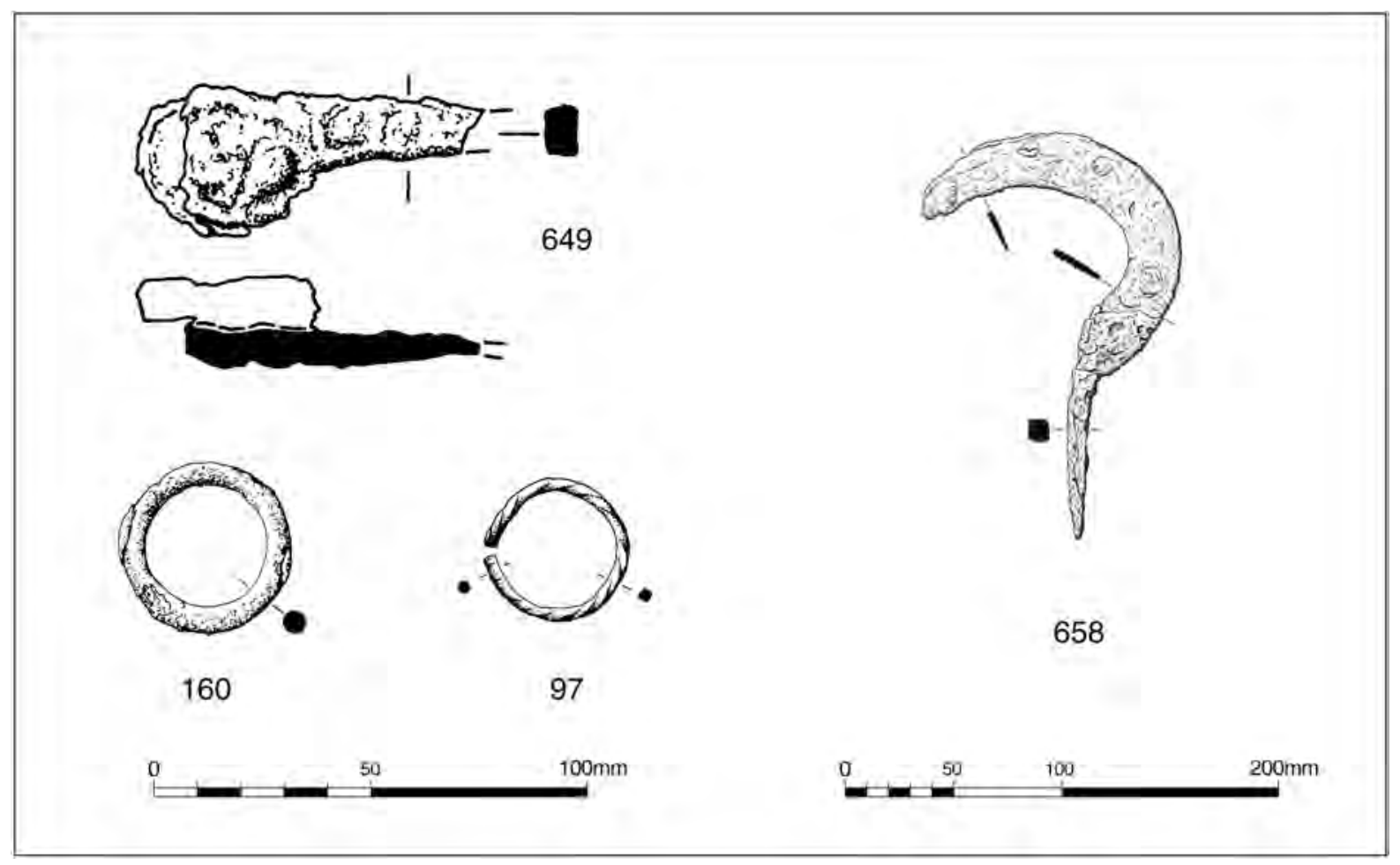

Illus 61 Copper alloy and iron objects

\section{Upper quernstones}

20 Complete irregular oval stone. Upper face is natural cortex of boulder apart from along some ancient breaks. Grinding face is consonant with edges; markedly convex about short axis and shallowly convex about long axis and dressed with peck mark. Greatest wear is concentrated at short ends. Dimensions $235 \times 210 \times 100 \mathrm{~mm}$. Find no 634 . Context: Pit O48/OBH.

\section{Other worked stones}

32 Approximately triangular-shaped rounded pebble, oval cup with rounded base pecked into upper face. Dimensions $130 \times 120 \times 80 \mathrm{~mm}$. Cup size $70 \times 55 \times c 20 \mathrm{~mm}$. Find no 566. Context: Cobble fill of ring-ditch, House 2.

45 Flattened oval pebble with smooth concave depression centrally placed on each flat face. Dimensions $85 \times 60$ $\times 35 \mathrm{~mm}$. Depression sizes $45 \times 45 \times 5 \mathrm{~mm} .40 \times 35 \times 5 \mathrm{~mm}$. Find no 234. Context: unstratified.

47 Small irregular oval boulder with upper face occupied by smooth dished concavity not consonant with edges. Dimensions $210 \times 195 \times 45 \mathrm{~mm}$. Find no 230. Context: House 3, ring-ditch fill.

50 Small, triangular boulder with circular concave depression on upper face showing a peck marked surface. Dimensions $165 \times 135 \times 65 \mathrm{~mm}$. Find no 559. Context: Cobble fill of ring-ditch, House 2.

61 Approximately oval pebble with one small flattened facet. Dimensions $70 \times 60 \times 55 \mathrm{~mm}$. Find no 553. Context: House 2, central floor area.

63 Approximately oval pebble with several flattened, slightly polished faces. Dimensions $105 \times 75 \times 65 \mathrm{~mm}$. Find no 630. Context: House 7, cobble-filled depression in central floor space.
65 Circular pebble with two polished faces; one flattened, other slightly convex. Dimensions $90 \times 85 \times 65 \mathrm{~mm}$. Find no 560. Context: House 2, fill of a shallow scoop in central floor space.

69 Oval-sectioned hone, both ends broken. Length $55 \mathrm{~mm}$, section $30 \times 20 \mathrm{~mm}$. Find no 59. Context: unstratified.

70 Approximately circular-sectioned hone possibly tapering to angular ends; ends are now detached in three pieces and do not join body of hone. Length (largest piece) $65 \mathrm{~mm}$, section $c 20 \mathrm{~mm}$. Find no 671 . Context: fill of fenceline $\mathrm{K} 5$ adjacent to House 7.

\subsection{Copper alloy (illus 61) by Fraser Hunter}

\subsubsection{Discussion}

The alloys used are all consistent with a pre-Roman date except for the twisted hoop, whose silvering indicates a Roman or later date. As would be expected, the sheet objects are unleaded while the cast ones include lead for ease of casting. Much of the material is so fragmentary that little can be made of it, although the sheet fragments from pit M5 are probably mounts, fittings or repairs from an organic object.

The most significant and puzzling find is the twisted hoop (illus 61). It most closely resembles the hoop of a penannular brooch, although there are problems with this identification, notably the different terminals. One could be seen as a variant Fowler type A3 (Fowler 1960), but there is no evidence that the other terminal has broken off as the ends are smooth and patinated. It cannot easily 
be explained as the reuse of another object: probes with twisted shafts are known, but the head would normally be modelled in the round, whereas the flattening inside suggests this was a primary design feature. Penannular brooch hoops are normally plain, although Roman examples are known with decorated, often ribbed hoops (eg Breeze 1974, 160, no 37). The silvering would also point to a Roman origin, as brooches were often decorated with white metal coatings. Although no precise parallels have yet been located, an origin as a variant Roman penannular brooch seems most likely.

\subsubsection{Catalogue}

DB78/96 Circular-sectioned rod fragment, slightly curved, broken at both ends. Unidentified. L 7.5mm, D $3 \mathrm{~mm}$. House 2 post-abandonment fill (CAB). Leaded bronze (trace silver, antimony, zinc) (see L Fraser comment based on surface X-ray flourescence (XRF) analysis by Laurianne Robinet and Katherine Eremin).

DB78/97 Penannular hoop formed from a spiral-twisted rod. One terminal is cut square, the other has a variant knob-and-collar moulding with a small, unexpanded knob and an elongated columnar collar, resembling a baluster moulding. This is defined only on the outside. The twisting is worn internally, especially opposite the terminals and near the moulded terminal. A slight white metal sheen on the surface was identified by XRF as silvering. The size, shape and wear resemble a penannular brooch, although the spiral twisting and non-matching terminals are unusual. External D $33 \mathrm{~mm}$, internal D $26.5 \mathrm{~mm}$, section $3 \mathrm{~mm}$. Hillwash over palisade east of House 2 (CAC). Leaded bronze (trace zinc). Illus 61.

DB79/652 Five sheet fragments; no original edges or surviving features. Heavily corroded. Largest fragment $15 \times 10 \times 1 \mathrm{~mm}$. Pit M5, fill under paving (MBK). Bronze (trace lead).

DB79/654 Nine flat sheet fragments, some slightly curved in section. One has a shallow linear channel some have original straight edges. Largest fragment 18 $\times 12 \mathrm{~mm}$; T $0.3-0.5 \mathrm{~mm}$. Pit M5, fill under paving (MBK). Bronze (trace lead).

DB79/655 14 fragments of flat or slightly undulating sheet; probably one object, although there are no obvious joins. Part of one rivet hole, two perpendicular corners (one rounded) and one angled one. One fragment bent as if clenched over an organic medium to act as a mount. Largest fragment $21 \times 17 \times 0.5 \mathrm{~mm}$. Pit M5, fill under paving (MBK). Bronze (trace lead).

DB79/656 Circular-sectioned rod fragment, broken at both ends and damaged on one side. Too small to identify, but may be a pin shank or perhaps a rivet. L 7, D $2 \times$ $2.5 \mathrm{~mm}$. House 8, ring-ditch fill (PAA). Leaded bronze (trace silver, barium, nickel, arsenic).

\subsection{Iron (illus 61) by Fraser Hunter}

\subsubsection{Discussion}

Of this sparse assemblage, only the sickle (illus 61) merits wider discussion. It is of balanced type, where the initial curve of the blade lies behind the axis of the tang (Rees 1979, 438-9, fig 136). These first appear in the late pre-Roman Iron Age, although they are commoner in Roman contexts (Rees 1979, 458; Manning 1985, 51). The earliest known Scottish examples are Roman Iron Age, in the hoards of Carlingwark (Kirkcudbrightshire) and Blackburn Mill (Berwickshire), and from Traprain Law (East Lothian; S Piggott 1953; Burley 1956, no 481). One from Tentsmuir (Fife), found with a shouldered bucket urn of later first millennium BC type may be earlier (unpublished: East Fife Museum SAAUM 1977.1993), although a Roman Iron Age date cannot be ruled out.

The deposition of the sickle in feature M69 may be linked to a series of Iron Age deposits of agricultural equipment. These have been seen as offerings with symbolic associations: it has been argued that sickles had a particular link with the agricultural cycle and hence concepts of fertility and prosperity (Hingley 1997, 13-15). Such special treatment of agricultural equipment is seen in the tools in the Carlingwark, Blackburn Mill and Eckford (Roxburghshire) hoards (S Piggott 1953), the sickle from a pit at Albie Hill (Dumfriesshire; Strachan 1999), the ard head from the substructure of Milton Loch crannog (Kirkcudbrightshire; C M Piggott 1953, 143-4; Rees 1979, 42-3), and the ard beam from a peat bog near Lochmaben (Dumfriesshire; Rees 1979, 43). Hingley has conveniently summarized other Scottish deposits of agricultural items (Hingley 1992, 23-4, 38-9). The Tentsmuir sickle and pot is a further likely example, although records are unfortunately vague.

\subsubsection{Catalogue}

Only iron from secure contexts has been catalogued in detail. A range of stray finds was recovered but none can be shown to be Iron Age, and they are probably post-medieval.

DB79/160 Ring, circular section. Probably a rod welded into a circle; no sign of a butt join, but corrosion obscures details. No evidence of wear to clarify function. External D $39 \mathrm{~mm}$, internal D $28 \mathrm{~mm}$, section $5.5-6 \mathrm{~mm}$. House 1 , central post B71 (AFB). Illus 61 .

DB79/649 Knife? Two non-joining fragments are best interpreted as parts of the tang and blade of a knife. The tang fragment is a tapering rectangular bar $(10 \times 5 \mathrm{~mm})$, probably aligned on the knife back; surviving L $28 \mathrm{~mm}$. The other fragment is part of a V-sectioned tapering blade, of width $23 \mathrm{~mm}$ and $\mathrm{T} 5 \mathrm{~mm}$. Overall $\mathrm{L}$ of the two fragments is $80 \mathrm{~mm}$. Pit M5, fill under paving (MBL). Illus 61 .

DB79/650 Ferrule? Heavily corroded with part of side missing, but broadly conical with remains of socket some $20 \mathrm{~mm}$ D. $48 \times 24 \times 17 \mathrm{~mm}$. Pit M5, fill under paving (MBL). DB79/651 Square-sectioned rod, too fragmentary to identify. Approx $5 \times 5 \mathrm{~mm}$ section, at least $34 \mathrm{~mm} \mathrm{~L}$. Pit M5, fill under paving (MBK).

DB79/658 Balanced sickle. The rectangular-sectioned tapering tang continues into the blade, which sweeps back then curves relatively sharply to an angled point. Handle L $74 \mathrm{~mm}$, section $10 \times 9 \mathrm{~mm}$. Blade W $26 \mathrm{~mm}$, chord L $85 \mathrm{~mm}$, T 3-4.5mm. Overall H $185 \mathrm{~mm} \times \mathrm{W} 118 \mathrm{~mm}$. Pit M69 (MAY). Illus 61. 


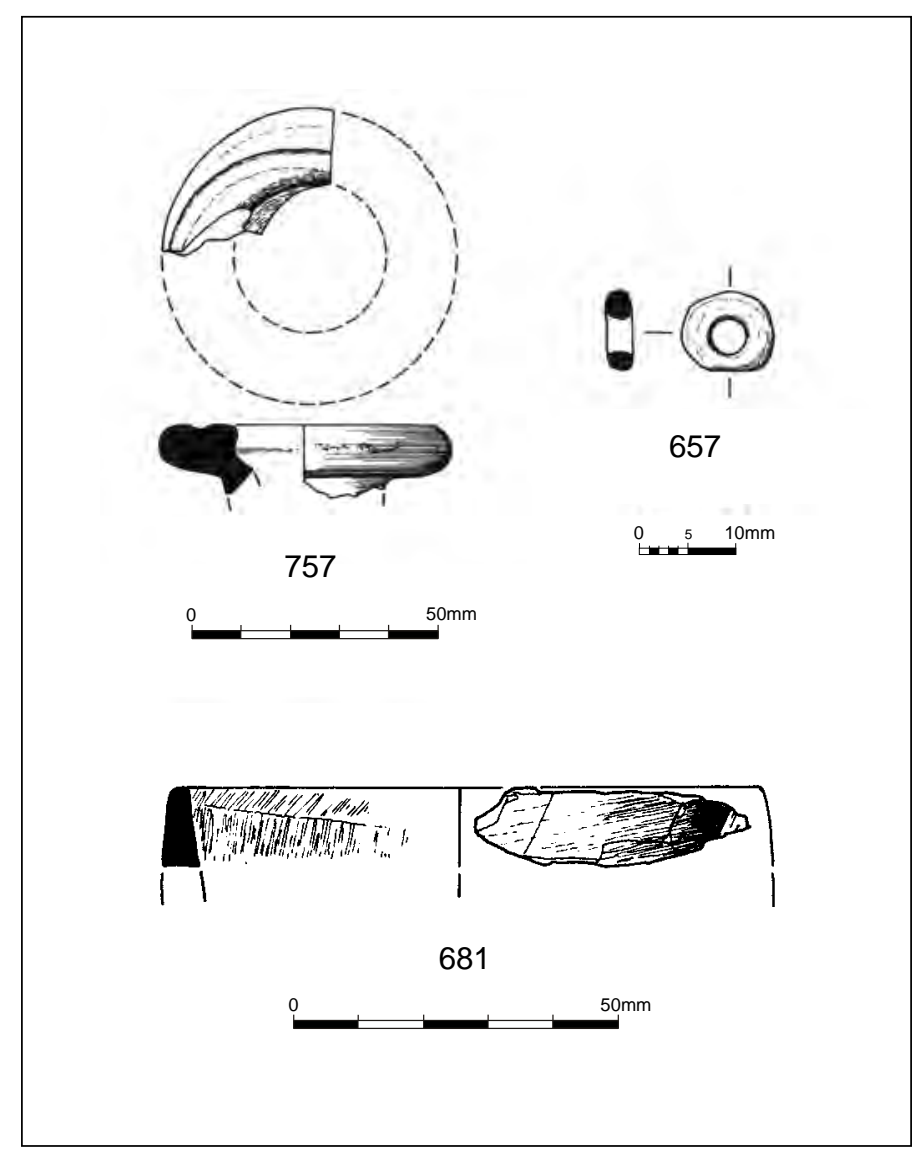

Illus 62 Glass and oil shale objects

\subsection{Roman glass (illus 62) by Dominic Ingemark}

\subsubsection{Discussion}

One rim-sherd of blue-green bottle glass was found at Dryburn Bridge. As the rims and necks of cylindrical, prismatic and rectangular bottles (Isings Forms 51, 50 and 90) are identical (Isings 1957, 63-9, 108), the detailed type could not be determined. However, as rectangular bottles are relatively rare (Price \& Cottam 1998, 201), it is most likely to represent a cylindrical or a prismatic bottle.

Although the earliest examples of these two types date to the Claudian period, only in the last quarter of the first century AD did they became common (Price $\&$ Cottam 1998, 191, 195). In Britain the cylindrical bottle was relatively short-lived, with production ceasing around $\mathrm{AD} 110$, whereas prismatic bottles were manufactured until around AD 200 (Cool \& Price 1995, 184; Price \& Cottam 1998, 191). The most likely date-range for this find would be $\mathrm{AD} 70-200$.

Bottle glass constitutes a significant proportion of assemblages on Roman sites between the Flavian period and the late second century AD (Cool $\&$ Price 1995, 236), reflecting its widespread use as a container for liquids, semi-liquids and solid foodstuffs (Isings 1957, 67-9; Charlesworth 1966, 26). There is, however, a lack of reliable chemical analyses of the contents, and it can only be assumed that narrow-necked bottles would have contained wine, olive oil and suchlike, whereas wide-necked bottles/jars could have contained honey or other foodstuffs. From depictions on tombstones and mosaics we also know that cylindrical bottles functioned as tableware in the Roman world, and there is much to suggest that it was for the serving of wine (Holwerda 1931, abb 20-1; DeMaine 1990, fig 3a; Masseroli 1998, fig 7).

No fewer than 28 native sites in Scotland and north Northumberland have yielded bottle glass, making it the single most common category of Roman vessel glass found in indigenous contexts (Ingemark 2003). It is primarily concentrated in the Scottish Lowlands and Northumberland, mostly - though not solely - on rich sites with a relatively wide range of other imported Roman goods. This could suggest a high value for the bottles, and thus that the contents rather than the actual bottle were the primary reason for importing them (Ingemark 2003). The heavy wear on much of the bottle glass found in native contexts bears witness to a more prosaic afterlife as containers once they were emptied of their original contents. In the case of the Dryburn Bridge find the relatively narrow neck suggests that it originally contained some sort of liquid - most 
probably wine - but whether it reached the site full or empty must unfortunately remain unknown.

\subsubsection{Catalogue}

DB79/757 Rim fragment of cylindrical or prismatic bottle. Blue-green. Usage scratches. Present height $14 \mathrm{~mm}$; thickness of rim $12 \mathrm{~mm}$; external rim diameter $c 65 \mathrm{~mm}$. Pit M69.

\subsection{Oil shale and cannel coal (illus 62) by Fraser Hunter}

\subsubsection{Discussion}

Bangles were commonplace in the Iron Age, and the disc bead also finds ready parallel (for example Traprain Law; Curle 1915, fig 27.1). The stratified bangle and the bead are from Phase III contexts, but the working debris confirms shale-working in Phase II (see Discussion). The bangle roughout and working debris demonstrate that such items were manufactured on site. More working debris was probably present but not recognized - recovery of this material in excavations is sadly deficient. While shale and cannel coal working has rarely been studied in detail, ongoing work by the writer shows that it was relatively common in East Lothian, being attested at North Berwick Law, Broxmouth, Craig's Quarry Dirleton and Traprain Law.

To investigate the raw materials used the objects were examined visually and analysed by X-ray fluorescence. With such a small group it is difficult to find patterns, but a range of materials was represented, mainly various oil shales with some cannel coal. The variety indicates exploitation of a range of sources. The raw material was available relatively locally - both oil shale and cannel coal occur in Carboniferous deposits on the coast south of Dunbar (Gibson 1922, 51-2; Greig 1971, 83, fig 14), although there has been no detailed study of their composition or working properties.

\subsubsection{Catalogue}

\section{Artefacts}

DB 78/273 Bangle portion, well-rounded D-section with circumferential and near-vertical manufacturing scars internally; extensive wear and post-depositional scratching, especially on exterior. L $33 \mathrm{~mm}, \mathrm{~B} 9 \mathrm{~mm}, \mathrm{H} 12 \mathrm{~mm}$, internal D 70-5mm (13\% survives). Cannel coal (markedly more organic than other items). Topsoil, unstratified.

DB79/681 Bangle fragment; tall lentoid section (now incomplete); vertical scars internally from manufacturing, externally well-finished. L 42mm, B $6 \mathrm{~mm}, \mathrm{H} 13 \mathrm{~mm}$, internal D 80-5mm (16\% survives). Markedly laminar structure - oil shale. Pit M69 (MAY). Illus 62.

DB79/657 Flat disc bead, the edge straighter in one area where there is a flaw. Edges rounded, with some residual faceting; cylindrical perforation (D 3mm) with rounded edges, slightly oval from wear. $9.5 \times 8.5 \times 3 \mathrm{~mm}$. Polish obscures structure - analysis similar to bangle 681 , probably oil shale. Pit M1, below rubble (MAC); ?boundary linked to House 8. Illus 62.

DB79/824 Whorl fragment? Broken disc, the partlypreserved edge forming a convex curve in section. Its size and material (a highly inorganic oil shale) suggests it is a whorl rather than a bead, as it would be heavy. Very worn after breakage. Original D $40 \mathrm{~mm} .23 .5 \times 19.5 \times 6.5 \mathrm{~mm}$. Location uncertain.

\section{Working debris}

DB79/842 Bangle roughout. Disc with one face that of the natural cobble, the edges cut and chipped to rough circle. Central conical indentation on one side (D $10 \mathrm{~mm}$, $4 \mathrm{~mm}$ deep), pair of similar indents (D $13 \times 5 \mathrm{~mm}$, D $7 \times$ $2.5 \mathrm{~mm}$ ) on the other (implying a mistake in initial layout). Abandoned perhaps because of spalling of the edges. D $112 \times 106 \mathrm{~mm}, \mathrm{H} 13 \mathrm{~mm}$. Cannel coal or canneloid shale. House 2, post-hole in central area.

DB78/220 Fragment of probable working debris - corner removed from a squared block. Tabular fragment, the edges cut square and the corner facetted; the fractured edge is worn, but behind it the surface shows signs of an earlier attempt at removal, with initial cutting and pecking. Surface worn, implying it was residual. Shale (markedly different elemental composition from others). $46 \times 28 \times 10 \mathrm{~mm}$. Upper fill of Burial 2 (DAS).

\subsection{Slag by Andrew Heald}

\subsubsection{Description}

A total of $944.2 \mathrm{~g}$ of slag was recovered. Visual examination allowed the material to be broadly categorized on criteria of morphology, density, colour and vesicularity (after Bachmann 1982; McDonnell 1986). However, each of the various production processes can create a wide range of slag morphologies depending on the temperature, duration and chemistry of the fuel, hearth linings and alloys used. Only tap slag and smithing hearth bottoms are truly diagnostic (of iron smelting and smithing respectively). Further elemental and mineralogical analyses would be necessary to classify other material more conclusively: this was not undertaken. The slag has been described and catalogued using common terminology (eg Bachmann 1982; McDonnell 1986): smelting slags; slag spheres; smithing slags; and fuel ash slag.

All of the slags are fractured and small. Such irregularly shaped slags can be produced by both iron smelting and smithing; differentiating through visual examination is difficult, and they are generally referred to as undiagnostic ironworking slags (see Starley 2000, 338). It is common for these to constitute up to $50 \%$ of a total site assemblage (Crew 1995). However, the morphology, density, colour and vesicularity allows some of the material to be classified more closely.

Two fragments have the appearance of smelting slags (SFs 550 and 596). One piece (SF 550) has a 
distinctive 'ropey' flowed morphology with very low vesicularity, characteristics common on smelting slags allowed to run from the furnace (Starley 2000, 338). Two other pieces (SFs 668 and 669) may also be smelting slags. Three pieces (SFs 503, 518 and 525) appear to be smithing residues. One slag sphere (SF 533), surface-oxidized iron expelled during hammering of iron, was also found. When found in quantities slag spheres are usually indicative of in situ smithing. However, the minute amount recovered from Dryburn Bridge is insufficient to prove this.

Three pieces of vitrified fuel ash were found (SFs 546, 588 and 730), slag formed when material such as earth, clay, stones or ceramics is subjected to high temperatures (for example in a hearth). These need not be associated with ironworking.

\subsubsection{Discussion}

The assemblage from Dryburn Bridge is very small, and there are no excavated features or diagnostic slags to indicate in situ metalworking. Analysis of context does little to broaden the picture: all the slags are either unstratified or in secondary contexts (Table 13).

Though indicative of ironworking in the vicinity, presumably somewhere on the site, the presence of the material does not prove in situ metalworking. Iron slag is known from other Iron Age sites in East Lothian, such as Fishers Road West, Port Seton (Heald 2000); St Germains (Alexander \& Watkins 1998, 249) and Broxmouth (Hill 1982a, 181, 188). However, discussion of intra- or inter-site differences is difficult as, like Dryburn Bridge, the quantities are small and derive from secondary or unphased contexts. That said, the Dryburn Bridge material is useful evidence for ironworking in the area in the earlier Iron Age.

\subsection{Antler (illus 63) by Fraser Hunter}

Two pieces of red deer antler were recovered from pit $\mathrm{O} 48$.

A substantial portion of a shed red deer antler ( $\mathrm{L}$ $500 \mathrm{~mm}$, crown diameter $c 50 \mathrm{~mm}$ ), in poor condition, with detached portions and worn edges (partly visible on illus 57). The bez and trez tines have been removed (the former apparently by chopping, the latter sawn), and there are scattered knife-cuts on the beam. The brow tine was attached when found but is badly damaged and now separate, the ends broken and worn. No wear traces or working marks are visible; the cancellous tissue is hollowed, but this probably arises from damage and subsequent conservation. In the absence of any clear working traces, its on-site interpretation as a pick cannot be sustained. It is necessary to be rigorous about this, as shed antlers stripped of their tines are too often identified as picks without firm evidence; yet this is often a stage in preparing the beam (generally the sought-after portion) for further working. The upper end is badly damaged, but there is a hint in one area that the end may have been cut square, removing the terminal tines. On the surviving evidence this looks like a red deer antler collected for raw material, partly prepared by removing most of the tines but abandoned before the beam was used.

More problematic is an unattached curved portion of beam (illus 63 ; L $150 \mathrm{~mm}$, W $48 \times 39 \mathrm{~mm}$ ). This does not appear on the site photographs (eg illus 57) and does not seem to fit the shed antler. It is thus likely (although not certain) that it is a separate item. The body is badly damaged, but the intact end

Table 13 Distribution of slag (with mass in grammes)

\begin{tabular}{|c|c|c|c|c|c|c|}
\hline Description of block & Context & $\begin{array}{l}\text { Smelting } \\
\text { slag }\end{array}$ & $\begin{array}{l}\text { Undiagnostic } \\
\text { ironworking } \\
\text { slag - smelting? }\end{array}$ & $\begin{array}{l}\text { Slag } \\
\text { sphere }\end{array}$ & $\begin{array}{l}\text { Undiagnostic } \\
\text { ironworking } \\
\text { slags - smithing }\end{array}$ & $\begin{array}{c}\text { Fuel ash } \\
\text { slag }\end{array}$ \\
\hline \multicolumn{7}{|l|}{ House 2} \\
\hline Cobble fill of ring-ditch & CGA & & 290.2 & & & \\
\hline Central floor area & CCR & 118.3 & & & & \\
\hline \multicolumn{7}{|l|}{ House 7} \\
\hline Fence-line K5 & $\mathrm{KAE}$ & & & 0.1 & 211.0 & \\
\hline Fill of ring-ditch & KAA & & & & & 7.6 \\
\hline $\begin{array}{l}\text { Sheep burial cut through south } \\
\text { side House } 7\end{array}$ & KEG & & & & & 2.4 \\
\hline \multicolumn{7}{|l|}{ Other } \\
\hline Curvilinear ditch O76 & OBK & 243.8 & & & & \\
\hline Rubbish pit $\mathrm{O} 48$ & $\mathrm{OBH}$ & & & & & 8.8 \\
\hline Unlocated or unstratified & KMB? & & & & 62 & \\
\hline
\end{tabular}




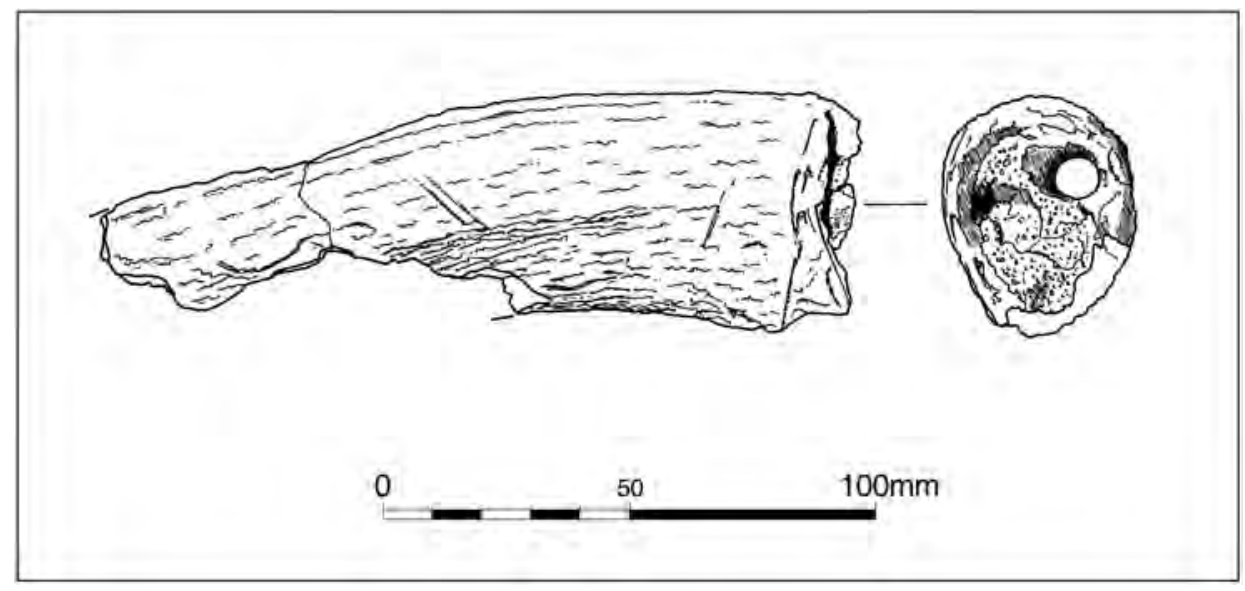

Illus 63 Antler fragment

is cut square with an off-centre cylindrical hole (D $10 \mathrm{~mm}$, min length $63 \mathrm{~mm}$ ) drilled into it; shallow hollows around this suggest earlier abortive drilling attempts. This suggests it was a handle for an item with a circular tang (and thus not a knife or similar bladed tool, as a circular tang allows too much movement in the handle).

\subsection{Discussion of the artefact assemblage by Fraser Hunter}

\subsubsection{Nature of the assemblage}

The assemblage from Dryburn Bridge is dominated by pottery and coarse stone, with the vast majority of the material being essentially prosaic and functional. Ornamental or exotic items are rare and tend to come from later phases, notably the Roman glass and the penannular brooch hoop. Shale bracelets are the only ornamental items that can be firmly linked to earlier phases, with the roughout from House 2.

Among the coarse stone, querns predominate. The abundance of saddle-querns fits an earlier Iron Age date. The finds also show some evidence of craft activities: iron smelting and smithing (although no primary in situ material was located) and the manufacture of shale jewellery. The sickle emphasizes the agricultural basis of the site. The other notable feature of the assemblage is the evidence of Roman contact in the bottle glass (and perhaps the brooch; F Hunter, pers comm). This does not indicate the site was special or privileged in its latest phase: Roman items are relatively commonplace in southern Scotland, with most sites having access to some material. It has been argued that this was moderated through a hierarchical structure with powerful individuals or groups controlling access (Hunter 2001). The choice of the material, connected most probably with drinking and ornament, is typical: Roman finds were selected because of their appropriateness for local habits (Hunter 2001).

\subsubsection{Taphonomy and deposition}

Table 14 summarizes the occurrence of finds across the site. This is highly variable, and depends in large part on the nature of the surviving deposits: hollows and ring-ditches provide artefact traps safe from ploughing, while cobbled surfaces and packing are the main sources of reused coarse stone tools. Those houses represented only by post-holes have correspondingly sparse finds assemblages. This makes it unrealistic to compare the material from different houses, and it is best treated by phase or (more realistically) as a whole.

The bulk of the material is fragmentary and appears to have been discarded or reused. There is a broad negative correlation between features producing stone and those producing pottery, suggesting different depositional patterns - notably the selective reuse of stone in paving and packing. This is true of many of the querns, although some perhaps were set into paving or pits as a solid base for grinding (for example Houses 2, $7 \&$ 8; but see reservations expressed by Dunwell in Section 7.4.4 and Cool in Section 8.2.1). The reuse of quernstones has potential symbolic as well as functional dimensions (eg Hingley 1992, 32), but this excavation pre-dated such concerns and there was no detailed recording of quern location, position, orientation and so on. Only with recurring patterns of placement can a strong argument for symbolic deposition be made. The differential distribution may be significant, with a marked concentration in House 2; however, this also has most coarse stone tools generally, suggesting it relates to greater reuse of stone. House 8 has a concentration of querns in the paving uncorrelated with other coarse stone, and here querns may have been preferentially selected; they are spread evenly across the paving rather than clustered (illus 32). Other ring-ditch houses show a similar pattern of large quantities of saddle-querns being deposited in the ditches (for example Douglasmuir, Kendrick 
Table 14 Distribution of finds (object count) at Dryburn Bridge (excluding features with few finds)

\begin{tabular}{|c|c|c|c|c|c|c|}
\hline Feature & Querns & Coarse stone & Pot & Metal & Glass & Slag \\
\hline House 1 & & & 1 & 1 & & \\
\hline House 2 & 13 & 24 & & & & $\mathrm{x}$ \\
\hline House 2 later infill & 2 & & 5 & 1 & & \\
\hline House 3 & 1 & 2 & 3 & & & \\
\hline House 7 & 5 & 3 & 1 & & & $\mathrm{x}$ \\
\hline House 8 & 6 & & & 1 & & \\
\hline House 9 & & 1 & & & & \\
\hline Boundary a & & 1 & 3 & & & $\mathrm{x}$ \\
\hline Boundary b & & 1 & 3 & & & \\
\hline Rectangular structures & & & 11 & & & \\
\hline Enclosure - inner & & 2 & 2 & & & \\
\hline Enclosure - outer & & & 16 & & & \\
\hline Hillwash (CAC) & & & 1 & 1 & & \\
\hline Feature K2 & & & 2 & & & \\
\hline Feature M5 & & & & 6 & & \\
\hline Feature M69 & & 2 & 5 & 1 & 1 & \\
\hline Feature 048 & 3 & 3 & 1 & & & $\mathrm{x}$ \\
\hline Feature O76 & 1 & & 1 & & & $\mathrm{x}$ \\
\hline
\end{tabular}

1995; Kintore, M Cook pers comm) and it is likely that this was not simply pragmatic.

Only with feature M69 can a strong case for structured deposition be made. As discussed in Section 8.4.2, the complete sickle fits a pattern of the deposition of agricultural implements, perhaps connected with rituals linked to the agricultural year. With the eye of faith it could be argued that the sherd of Roman glass from the same feature was significant, perhaps the disposal of a powerful and exotic token, but there is insufficient detailed contextual information to support this over more mundane fates. Of the other features with finds, it is hard to argue for structured deposition, with pit M5 and hollow O76 having only very fragmentary material. Pit $\mathrm{O} 48$ is more striking, especially in the quantity of coarse stone tools, both intact and broken. It may be a rubbish pit, but could be an example of the structured deposition of material as part of 'pit ritual', as attested most notably in Wessex (J D Hill 1995). Given the rarity of metal on the site, the presence of an iron ring in the central post-hole of House 1 may also be significant. While worth noting, a broaderranging regional survey is required before the significance of these deposits can be assessed.

\subsubsection{Regional patterns}

Cool has noted how prosaic and restricted earlier Iron Age assemblages are in contrast to later ones in south-east Scotland (Cool 1982, 99), and more recent work has confirmed this. At Myrehead (Falkirk), for instance, the most striking finds (dagger fittings) came from a late Iron Age pit; with the exception once more of a shale bracelet, the assemblage was otherwise entirely functional (Barclay 1983). The same is true of Eildon Hill North, where the ornamental bronzework and glass is late Iron Age (Rideout et al 1992, 145-51). This is not an absolute: there are late Iron Age sites with poor surviving assemblages (for example Fisher's Road West; Haselgrove \& McCullagh 2000, 30-9, 69), and earlier sites can have less prosaic finds (for example a stone ball and two discs from Douglasmuir; Kendrick 1995, 58). However, in general, the pattern seems to hold.

Some qualifications must be entered. The wide range of bone pins from Broxmouth shows that our view of ornaments is badly skewed by the general absence of bone (Cool 1982; Hill 1982a, 182-3). Ornaments are not unknown in the earlier Iron Age, with shale and cannel coal jewellery occurring regularly. However, these materials were widely available in the Lothians and their role was doubtless different from the more technically complex or exotic bronze and glass items. If they had a role beyond the ornamental, it was presumably in marking out identity not in terms of status but other affiliations such as kin, age or sex. Finally, the rarity of earlier Iron Age bronzework may in part stem from depositional bias; it seems there was no tradition of depositing such ornaments on settlement sites, in contrast to areas such as Wessex. Despite this, there does seem to be a change in the later Iron Age and Roman Iron Age; more ornamental material and a wider range of artefacts, including stone tools, 
were being deposited. This may in part represent depositional habits but is also likely to reflect social changes in the use of material culture. These are as yet unstudied in Scotland, but may be related to similar trends noted in southern Britain (J D Hill 1995). The Dryburn Bridge data, while insubstantial, would support such a trend.

The Dryburn Bridge assemblage stands ready comparison with the material from Myrehead (Barclay 1983) and Douglasmuir (Kendrick 1995), with the stone showing an abundance of saddle-querns and cobble tools, and limited shale/cannel coal jewellery; the bulk of metal items, if present, come from late contexts. Clarke has noted a tendency for sites to have local peculiarities in their coarse stone (Clarke 1998, 389), and this is seen at Dryburn Bridge with the preponderance of hollowed or cupped stones whose function is unclear. Here we are seeing local practice and adaptation in action. In comparison to assemblages with a significant later Iron Age phase such as St Germains (Alexander \& Watkins 1998) or the Dunion (Rideout et al 1992, 152-7) there is an absence not just of rotary querns but also balls, counters, discs and even spindle whorls.

The other material is more difficult to compare. The pottery assemblages are dominated by cooking vessels on most sites, although ongoing detailed study of the region's pottery by Cath McGill should reveal more subtle patterns; sadly, the Dryburn Bridge pot has been lost since excavation. The craft processes such as shale/cannel coalworking and ironworking are common on many sites, although they have not yet been synthesized on a regional level to look for trends and variations. The Roman items have been discussed above - Roman material is not uncommon in south east Scotland, but the quantities present do not indicate Dryburn Bridge was any form of power centre in its latest phase.

In summary, while outwardly unprepossessing, the Dryburn Bridge material can be used to investigate a series of issues about material culture and its uses in the southern Scottish Iron Age. While it may not answer many questions, it is a valuable assemblage to add to the debate. 


\section{Faunal and Human Remains from the Iron Age Settlement}

\subsection{Animal bone by Jennifer Thoms}

\subsubsection{Introduction}

A report on the animal bones recovered during the excavation was produced $c 1980$ by Mary Harman. The material has been reassessed in the light of the developments that have occurred in the theory and methodology of zooarchaeology in the years since that time. Harman's original report is included in the project archive, and this account includes consideration of taphonomy (Lyman 1994), in an attempt to learn something about site formation processes, and to examine the pit contents in the light of recent research on 'special animal deposits' (J D Hill 1995).

\subsubsection{Methods}

The bones were cleaned, bagged and boxed when the current worker first encountered them. Nothing is known of the sampling strategy employed during the excavation, nor whether the bones collated in the boxes represent all the bones collected during excavation, or a percentage of those bones surviving on site.

As the bones had been identified to element and species by Harman, and any unidentifiable fragments classified as such, this normally time consuming process was not repeated. Harman's report made no mention of what criteria had been used to distinguish between sheep and goats. In this report the term caprines describes both sheep and goat identified by Harman since they could not be distinguished using Boessneck's criteria (Boessneck 1969).

Each fragment was examined closely for taphonomic indicators, such as gnaw marks and signs of burning, both of which have implications for the taphonomic history of the bone deposits and, in turn, on the site formation processes (cf Binford 1978; Meadow 1980; Brain 1981; Hesse \& Waspnish 1985; Lyman 1994; Reitz \& Wing 1999; O'Connor 2000).

All fragments were sorted into size categories of $10 \mathrm{~mm}$ apart. For example, a bone fragment measuring $24.7 \mathrm{~mm}$ would be classed in the ' $<30 \mathrm{~mm}$ ' group.

All fragments were assessed for preservation state and graded on a scale of A to D where 'A' indicates a fresh appearance with no surface degradation, 'B' a duller, slightly degraded surface and 'C' a more highly damaged surface but with at least half of the bone surface remaining intact. A bone with more than half of its surface severely abraded or missing, revealing the internal structure, was categorized as ' $\mathrm{D}$ '.

\subsubsection{Results}

No faunal remains were retrieved from contexts believed to date from Neolithic and Bronze Age activities.

The bone-bearing contexts from the Iron Age settlement are grouped into feature types, to facilitate incorporation of the faunal results into the interpretation of the site as a whole. The features that contained animal bones are discussed in the same order as in the foregoing site description (Section 7). Table 15 displays the results of the animal bone analysis, listing the features that contained animal bones and the species and skeletal parts (elements) they contained. Large quantities of small indeterminate fragments were retrieved from all features and have not been listed on Table 15 unless the feature produced no identifiable bone fragments whatsoever.

The bone fragments were also studied for taphonomic indicators and the state of fragmentation of the bones in each feature was assessed. The information is presented in Table 16.

\subsubsection{Outer enclosure palisade trench}

Terminal post-hole on the south side of the north-east entrance Twenty samples of animal bone fragments had been retrieved from the fill (Context ACA) of the pit on the south side of the north-east entrance. A fragment of pig ulna, one of only five pieces of pig bone retrieved from the site, was present in one of the samples. The good condition of the bone fragments may suggest rapid infilling of the pit.

Palisade trench AAQ Three maxillary molars were retrieved from the palisade trench north of pit ACB. They were from cattle, caprine and pig. The pig molar was only just in wear, indicating a young animal. No other bone fragments were present in the samples from this context and many factors might contribute to the retrieval of three teeth from the context including the fact that enamel is more durable than most bone material, and, possibly, the higher visibility of teeth in the trench.

\subsubsection{Inner enclosure palisade trench}

Only teeth fragments were retrieved from the contexts associated with the inner palisade trench. Tooth enamel is more resistant to decay in acidic 
Table 15 The animal bone retrieved from various features at Dryburn Bridge

\begin{tabular}{|c|c|c|c|c|}
\hline Feature & Species & Element & Frag & Taph \\
\hline \multirow[t]{4}{*}{ Outer enclosure palisade } & Cattle & Teeth + enamel metapodial & Fragments & \\
\hline & Caprine & Tooth, tibia, humerus metacarpal & Fragments & \\
\hline & Pig & Tooth, ulna & Fragments & \\
\hline & Pig & Milk tooth & Complete & \\
\hline \multirow[t]{2}{*}{ Inner enclosure palisade } & Cattle & Tooth + enamel & Fragments & \\
\hline & Caprine & Tooth & Fragment & Burnt \\
\hline \multirow[t]{2}{*}{ Houses 5 and 6} & Cattle & Metapodial & Recent break & \\
\hline & Horse & Skull & Fragment & \\
\hline \multirow[t]{2}{*}{ House 1} & Cattle & Mandible & Fragment & \\
\hline & Caprine & Astragalus, teeth & Fragment & \\
\hline House 9 & Indet & Indet & & \\
\hline House 3 & Cattle & Tooth enamel & Fragments & \\
\hline House 8 & Indet & Indet & & \\
\hline House 7 & Indet & Indet & & Burnt \\
\hline \multirow[t]{3}{*}{ House 2} & Cattle & $\begin{array}{l}\text { Humerus } \\
\text { Tooth } \\
\text { Pelvis } \\
\text { Radius } \\
\text { Scapula } \\
\text { Tibia }\end{array}$ & $\begin{array}{l}\text { Fragment } \\
\text { Fragments } \\
\text { Fragment } \\
\text { Fragment } \\
\text { Fragment } \\
\text { Fragment }\end{array}$ & $\begin{array}{l}\text { Butchered } \\
\text { Burnt }\end{array}$ \\
\hline & Red deer & $\begin{array}{l}\text { Antler } \\
\text { Antler (cast) }\end{array}$ & Fragment & Butchered \\
\hline & Horse & Tooth & & \\
\hline Structure D & Indet & Indet & & \\
\hline \multirow[t]{2}{*}{ Pit grave - B3 } & Caprine & Third molar & Complete & \\
\hline & Indet & Indet & & Burnt \\
\hline Pit grave - B2 & Indet & Indet & & \\
\hline Pit grave - B 12 & Indet & Indet & & \\
\hline \multirow[t]{2}{*}{ Pit E1 } & Cattle & Teeth & Fragments & \\
\hline & Caprine & Radius & & \\
\hline \multirow[t]{2}{*}{ Pit M1 (MAC) } & Cattle & $\begin{array}{l}\text { Third phalanx } \\
\text { Teeth } \\
\text { Metapodial } \\
\text { Pelvis } \\
\text { Scapula } \\
\text { Tibia } \\
\text { Tooth enamel } \\
\text { Vertebra }\end{array}$ & $\begin{array}{l}\text { Complete } \\
\text { Fragments } \\
\text { Fragment } \\
\text { Fragment } \\
\text { Fragments } \\
\text { Fragment } \\
\text { Fragments } \\
\text { Fragment }\end{array}$ & \\
\hline & Pig & Humerus & Fragment & \\
\hline F2/F3 (FAA) & Indet & Indet & 1 fragment & \\
\hline O36 (OBA) & Indet & Tooth enamel & Fragments & \\
\hline \multirow[t]{2}{*}{ Pit M69 (MAY) } & Cattle & $\begin{array}{l}\text { Horn core } \\
\text { Skull } \\
\text { Tooth enamel } \\
\text { Rib }\end{array}$ & & Gnawed \\
\hline & Caprine & Third molar (unworn) & Complete & \\
\hline Pit M43 & Dog & Almost complete skeleton & & \\
\hline Pit M5 (MAX) & Cattle & Maxillary molar & Fragment & \\
\hline
\end{tabular}


Table 15 (contd.) The animal bone retrieved from various features at Dryburn Bridge

\begin{tabular}{|c|c|c|c|c|}
\hline Feature & Species & Element & Frag & Taph \\
\hline \multirow[t]{5}{*}{ Pit O48 (OBH) } & Cattle & $\begin{array}{l}\text { Axis vertebra } \\
\text { Teeth + enamel } \\
\text { Metacarpal } \\
\text { Tibia }\end{array}$ & $\begin{array}{l}\text { Fragment } \\
\text { Fragments } \\
\text { Fragments } \\
\text { Fragment }\end{array}$ & \\
\hline & Red deer & Antler & Large fragment & \\
\hline & Horse & $\begin{array}{l}\text { Metapodial } \\
\text { Maxillary tooth }\end{array}$ & $\begin{array}{l}\text { Fragment } \\
\text { Complete }\end{array}$ & \\
\hline & Caprine & Metatarsal & Fragment & \\
\hline & Pig & Third molar & Complete & \\
\hline \multirow[t]{2}{*}{ Pit LEL } & Cattle & Metapodial & & \\
\hline & Indet & Indet & Burnt & \\
\hline Pit OBL & Indet & Indet & & \\
\hline Pit OCP & Indet & Indet & & \\
\hline Pit LAB & Cattle & Horncore & & \\
\hline
\end{tabular}

Frag, fragmentation state; Taph, taphonomic indicator; Indet, indeterminate fragment.

conditions than is bone, so the finds reflect poor preservation conditions in that area of the site.

\subsubsection{Houses 5 and 6}

Three contexts from Houses 5 and 6 contained animal bone remains. FBX corresponds to the fill of the outer entrance post-pit L60 (illus 21) and FCT corresponds to the fill of the southernmost middle post-pit in the entrance to House 6 (L61). Context FBC is the fill from one of the post-holes in the postring of House 6.

Context FBX contained a very abraded, friable fragment of cattle metapodial that may have deteriorated further since excavation. The fill of L61 contained some small fragments of skull. This was identified by Harman as horse, suggesting it may have fragmented further since her initial analysis, as its present highly fragmented condition would preclude such an identification. Horse is rather rare in the Scottish zooarchaeological record, due to its role as a non-food animal. Hippophagy has been frowned upon by the church since at least medieval times and it seems likely that, even earlier, the animal's usefulness for traction and transportation, together with its slow reproduction rate, would increase its perceived value and so make its consumption less likely. Thus horse tends not to end up on the rubbish heaps or middens commonly excavated by archaeologists, resulting in a scarcity in the archaeological record. The occurrence of horse skull fragments in a pit, particularly a pit that may have had a defining role at the entrance of the house, may therefore be a matter of interest. In this instance, however, the small size of the fragments precludes against drawing any conclusions about their presence in the pit as they may represent re-deposited material.

\subsubsection{House 7}

Features relating to House 7 Context KAB was the fill of structure K2 (illus 3) and contained more complete, identifiable animal remains than did the internal structures sampled in House 7. The faunal remains included two left horn cores, a fragment of mandible with an almost complete tooth row (third premolar to third molar present) and a fragment of pelvis, all from cattle. One indeterminate fragment was burnt and calcined and was the only burnt bone retrieved from the feature, the pelvis fragment displayed butchery marks and both bones were reasonably well-preserved (B).

\subsubsection{House 2}

As indicated in Table 15 and Table 16, this more complete house had more bone fragments retrieved from it than the other features on site. Some difficulties exist with correlating the contexts containing bone with the three phases of House 2, so each context will be considered separately.

Context CEQ was the fill of a scoop between the two ring-grooves in House 2 (illus 39). Bone material excavated from context CEQ included worked red deer antler and butchered cattle humeri. The cattle humeri, all from the left side of the body, were derived from at least three animals, and were all heavily butchered. A piece of cattle scapula, also from the left side of the body was also present among the bones from this context, as was half a radius, from cattle and from the right hand side of the body. The slight over-representation of bones from the left side of the body is not particularly surprising; all three humerus fragments are from the distal end of the bone, the most dense part of the humerus and one of the most structurally dense parts of the skeleton. While the deposition 
Table 16 Fragmentation and preservation of animal bone

\begin{tabular}{|c|c|c|c|c|c|}
\hline Feature & Burnt frags & No of Frags & Context & $\%$ smaller than $20 \mathrm{~mm}$ & $\begin{array}{c}\% \text { well-preserved } \\
\text { ('A' and 'B') }\end{array}$ \\
\hline \multirow[t]{2}{*}{ Outer enclosure palisade } & $\checkmark$ & $\begin{array}{l}67 \\
96\end{array}$ & ACA & $\begin{array}{l}52 \\
56\end{array}$ & $\begin{array}{l}59 \\
57\end{array}$ \\
\hline & & 22 & AAR & 55 & 86 \\
\hline Inner enclosure palisade & $\checkmark$ & 76 & & 66 & 72 \\
\hline House 1 & $\checkmark$ & 126 & & 66 & 87 \\
\hline House 9 & $\checkmark$ & & & $\mathrm{n} / \mathrm{a}$ & 0 \\
\hline House 3 & $\checkmark$ & 23 & & 56 & 40 \\
\hline House 8 & & 19 & & 73 & 26 \\
\hline House 7 & $\checkmark$ & 19 & & 95 & 0 \\
\hline House 2 & $\checkmark$ & 169 & & 51 & 60 \\
\hline Burial 12 & & $100+$ & & $\begin{array}{c}100 \\
(100+ \\
\text { tiny fragments })\end{array}$ & 100 \\
\hline Pit E1 & $\checkmark$ & 254 & & 70 & 98 \\
\hline Pit M1 & & 61 & & 4 & 19 \\
\hline Feature M69 & $\checkmark$ & 216 & & 68 & 97 \\
\hline Pit 048 & $\checkmark$ & 279 & & 58 & 24 \\
\hline Pit LEL & $\checkmark$ & 7 & & 100 & 33 \\
\hline Pit OCP & $\checkmark$ & 23 & $\mathrm{OCP}$ & 83 & 13 \\
\hline
\end{tabular}

of three similar fragments of bone into one context might represent an example of a structured, or special deposit (sensu J D Hill 1995) it might equally well represent the activity of one carnivore, such as a dog, hoarding bones, or it may be table or butchery waste.

Context CAQ corresponds to the upper fill of the ditched feature and contained three fragments of bone $20-40 \mathrm{~mm}$ in length. They were reasonably well-preserved (B) and showed no signs of burning or calcification.

Context CFA was the fill of the largest pit within the floor of the building. Of the 18 fragments of bone retrieved from this feature, 16 were unidentifiable and, of these, one was severely abraded and one was burnt. The identifiable bones comprised one fragment each of cattle tibia and pelvis.

Another context, CFR, the cobble infill of the ring-ditch, produced only tooth enamel fragments, again from cattle. The post-abandonment infill of House $2(\mathrm{CAB} / \mathrm{CBC})$ produced teeth and indeterminate fragments, predominantly derived from cattle or a similar larger mammal. One fragment of horse molar was retrieved from CBC. Of the 17 fragments retrieved from $\mathrm{CAB}$, two were burnt and the majority (14) were in a reasonable state of preservation (B), while three were poorly-preserved (C). CBC contained around a hundred small $(<50 \mathrm{~mm})$ fragments of tooth and tooth enamel, the majority from cattle. Some cattle teeth were also retrieved in samples labelled simply as 'House 2'.

\subsubsection{Pit graves}

Very little animal bone was found associated with any of the burials. One lower third molar from a caprine was retrieved from the fill of Burial 3, along with one indeterminate fragment of burnt bone less than $20 \mathrm{~mm}$ long. There is no reason to attach any significance to the animal tooth in this context, as it could as easily have been present within the soil matrix used to fill the graves.

The fill of Burial 12, context FDA, contained over a hundred fragments of bone less than $10 \mathrm{~mm}$ in length. They showed no signs of burning and were poorly preserved (D). It is possible that this is human bone, sampled before the grave was recognized as such, particularly as the human remains in this grave were of a fragmentary nature (Section 9.2). The poor state of survival of this bone sample does not permit further speculation.

\subsubsection{Pitted boundaries articulating with House 8 porch (illus 3, b)}

Pit E1 contained one caprine radius fragment less than $50 \mathrm{~mm}$ long and one fragment of long bone from a large mammal such as a cow. Other bone material from this pit consisted of small indeterminate fragments of burnt, calcined bone and tooth enamel, plus some fragments of cattle teeth. The cattle teeth fragments were in very good condition, possibly indicating rapid infilling of the pit. 
Pit M1, fill context MAC, contained several relatively complete and identifiable bone fragments. Cattle bones retrieved included two scapula articular ends, a distal end of tibia, a maxillary molar, a pelvis acetabulum articulation, a proximal metapodial fragment and a distal phalanx. All these skeletal areas are composed of structurally dense bone, which probably explains their survival. However, the lack of even such structurally dense bones on other parts of the site indicates that bone survival is better here than elsewhere. A fragment of pig humerus was also present in Pit M1 as well as several indeterminate fragments of bone in fairly poor condition (C). None of the bone in M1 was calcined or showed any other signs of burning. There is nothing about the bone assemblage from these pits to indicate it is anything other than domestic refuse.

\subsubsection{Feature M69 and dog burial (M43)}

The fill of pit M69 (illus 54), context MAY, contained fragments of cattle skull, including a $150 \mathrm{~mm}$ long piece of horn core, approximately 200 indeterminate skull fragments, some tooth enamel fragments and two pieces of rib from a cattle-sized animal. One rib fragment had gnawing marks on it, and was the only piece of bone retrieved that exhibited evidence of carnivore gnawing. A mandibular third molar from a caprine was also present in this context, and was unworn, suggesting it derived from an animal of between one and two years old (Payne 1973). Burnt, calcined indeterminate bone fragments and fragmented tooth enamel were also present in this context.

The insertion of a dog burial (M43) obscured the relationship between pit M69 and the outer enclosure palisade trench. The dog skeleton is almost complete with parts of both maxillae and mandibles surviving. Other bones present include one cervical vertebra, seven lumbar vertebra, part of the sacrum, three caudal vertebrae, a few rib fragments, most of the pelvis and fragments of both scapulae. The limb bones are even better represented with most of both humeri, both radii and ulnae, six carpals, four metacarpals, seven phalanges, both ends of the right femur, both tibiae, parts of the fibulae, the left calcaneus and astragalus, two tarsals and five metatarsals all present.

The dog skeleton was in reasonable to poor condition (B to C) and the bones were fragile. All epiphyses present were fused to the diaphyses and the teeth were moderately worn, indicating the dog was several years old, certainly mature rather than juvenile.

Unfortunately no complete long bones survived so an estimate of withers height of the living dog could not be made. However, the size and gracility of the bones indicate a small- to medium-sized dog, similar in size to a modern spaniel or small collie.

The dog burial is of particular interest because the upper right forelimb had fractured and healed.
This resulted in swelling along most of the length of the ulna and radius and slight bowing of both bones in the anterio-posterior plane, resulting in the right forelimb being around $10 \mathrm{~mm}$ shorter than the left one. Examples of healed fractures in animal bones are rare in the archaeological record, and may suggest that the dog enjoyed the sort of status today accorded to pets, rather than being a working animal. It can be envisaged that a pet, valued for companionship, would be allowed, or indeed encouraged, to survive a bone fracture, whereas an animal kept primarily for working might not be kept alive if it was unable to run. There is no reason to doubt that animals were valued for companionship in the past, just as they are today, and there is written evidence of this in early Irish legal texts.

Pet dogs were particularly associated with highranking women in these sources. A dog's duties include providing company and a function in protecting a woman from fairies when she was giving birth (Kelly 1998, 120). The dog was itself protected by legislation against killing it; anyone doing so faced steep fines and the obligation to provide a priest to read scripture throughout the labour in its stead. Therefore the importance of animals in noneconomic roles in the past can be demonstrated, and the idea that the dog buried at Dryburn Bridge might have been of some importance cannot be ruled out. The archaeological evidence that the dog was buried in a carefully stone-floored grave tends to accord with such a possibility.

\subsubsection{Pit O48 (illus 3; illus 57)}

Pit $\mathrm{O} 48$, context $\mathrm{OBH}$, contained a considerable amount of bone and some antler (Section 8.8). An unworn third molar from pig was retrieved, suggesting an older animal than might be expected in an archaeological context. This tooth does not erupt until the animal is between 17 and 22 months (Silver 1969) and as most pigs are slaughtered for meat before that age the tooth may indicate a breeding animal. The tooth is unworn which might indicate that the animal was unsuccessful as breeding stock, dying or being killed later in life than expected if killed for food, but not living to be a productive breeding sow. The death may have been due to disease, infertility or the lack of another animal for the cooking pot.

Context OBH also contained indeterminate bones bearing butchery marks, and both burnt and unburnt bone material. None of this faunal evidence argues against the original suggestion that this feature represents a rubbish pit.

A particularly large antler from a red deer was also present in Pit O48 (Section 8.8). The large size of the antler indicates it came from an animal larger than most found in Scotland today. Red deer size varies considerable according to their nutrition base and the environment in which they live. They are at the edge of their tolerated habitat 
range today in Britain and living in a resourcepoor environment (Red Deer Commission 1981, 10; Clutton-Brock et al 1982, 11). It is known that stags reared on farms or parks can grow up to twice as large as hill animals from the same gene pool (Callandar \& MacKenzie 1991, 54). The large size of this antler indicates a more favourable environment for red deer in the Iron Age than they experience in the Highlands today. The antler was cast, so does not indicate the animal had been hunted. It need not represent a local animal either, as antlers may have been a traded item.

\subsubsection{Conclusion}

The faunal evidence indicates that cattle, sheep or goats and horses or ponies were present on the site. Few gnawing marks were present on the bones, indicating either that dogs were not commonplace or that most bone material was deposited and buried rapidly. Red deer was only represented as shed antler, which may have been collected locally or traded from elsewhere. Larger, compact bone survived better than bone from smaller animals, or more cancellous material. Differential survival of bone precludes any detailed economic reconstruction as large animals such as cattle are over-represented in the faunal remains as a result of taphonomic processes.

The animal bone material is generally in reasonable condition, but highly fragmented, and was present in most contexts in quantities too small to be useful. The bones in the dog burial were soft and friable, indicating that their mineral content had been destroyed, presumably by acidic soil conditions, leaving the organic components more intact. Chemical removal of the inorganic component of the bones would explain why they were generally reasonably well-preserved but very fragmented.

Larger bones and more structurally dense body parts, such as distal humeri, survive this chemical action longer than do smaller, more porous bones. In the case of the human burials, most bones would be large enough to withstand chemical destruction, and the smaller bones from the limb extremities might be expected to survive due to their high structural density. The state of bone preservation seems to mirror the archaeological preservation generally with House 2 and the features in the south-west of the site producing bone that was better preserved than elsewhere. Much of the surviving bone had been burned, as the mineralization that takes place in the burning process aids preservation in certain soil conditions.

\subsection{Human remains from the pit graves by Julie Roberts}

\subsubsection{Introduction}

The ten skeletons excavated from Iron Age pit graves in 1978 and 1979 were originally analysed by
Harman (report contained in project archive). Methodologies used in the current analysis are recorded in Appendix I.

The condition of the burials varied greatly, but generally speaking the skeletons in the Iron Age pit burials were in a far worse state of preservation than those from the Bronze Age cists. The Iron Age burials had not been well protected in their pits, and as well as being susceptible to the detrimental effects of physical and chemical agents in the soil, stones had been placed directly on top of them at the time of burial. An assessment of the state of preservation of each articulated skeleton was made, based on the percentage of the skeleton surviving, the amount of fragmentation present and the degree of surface erosion to the bones. All ten individuals were less than $40 \%$ complete; seven were considered to be 'very poor' and three were 'poor'.

\subsubsection{Age at death and sex}

All the Iron Age burials were adults. Using one or more of the methods outlined in Appendix I, it was possible to assign an age range to five. The remaining five could only be termed 'Adult', although one was thought to be older than 25 years, and two were thought to be older than 30 years at death. Table 17 summarizes the age at death and sex data of the Iron Age burials.

Table 17 Summary of ages at death and sex of Iron Age burials

\begin{tabular}{lll}
\hline Burial no & Age at death & Sex \\
\hline 1 & $>30$ years & Unknown \\
2 & $25-30$ years & Female \\
3 & $>30$ years & Unknown \\
6 & $>25$ years & Male \\
7 & Probable adult & Unknown \\
8 & 18-25 years & Unknown \\
9 & $30-40$ years & Male \\
12 & $28-35$ years & $?$ Male \\
13 & $25-35$ years & $?$ Female \\
14 & Adult & $?$ Female \\
\hline
\end{tabular}

The sex of six of the adult individuals could be determined. The remainder were too poorly preserved and lacked sexually dimorphic elements. Two were female, one was a probable female, two were male and one was a probable male. This makes a male to female ratio of $1: 1$ if the probable and definite males and females are added together, respectively. If it had been possible to determine the sex of the remaining four adults, this ratio may obviously have been different.

In previous studies of 'normal' prehistoric and medieval populations (those that are not besieged 
by famine or warfare), there has been a tendency for larger numbers of females to appear in the young adult age range, and this has been attributed to deaths during childbirth (Roberts \& Manchester 1997). In this instance, there were no clear patterns.

\subsubsection{Metric data}

Very few cranial or post-cranial measurements were possible given the fragmentary state of the skeletal material. Details are included in the full osteoarchaeological report contained within the project archive.

\subsubsection{Health and disease}

Although the state of preservation of the remains was poor, it was still possible to undertake a reasonably comprehensive assessment of any pathological conditions present due to the relatively high survival rate of joint surfaces, fragments of shafts of long bone and rib, and dentition. This meant that conditions such as dental disease, degenerative joint disease and infectious disease could potentially be identified.

Dental disease The preservation of the dentition of even the more poorly preserved burials was generally good. Even in cases where the roots and pulp of the crown had degraded leaving only the outer enamel shell, it was still possible to examine the teeth for oral pathologies such as caries and dental enamel hypoplasia. A total number of 102 teeth were recovered from the Iron Age individuals. The frequencies and types of dental diseases observed will be discussed below in terms of overall frequency rates within and between the groups and also with reference to individual burials.

Three carious lesions were identified, giving an overall prevalence rate of $1.5 \%$. Two of the Iron Age individuals were affected, a probable male who had two small lesions (Burial 12) and a female who had one lesion (Burial 2). The affected teeth were mandibular molars of Burial 12 and the right maxillary second molar of Burial 2. The lesions were small and slight in severity. None of the individuals had suffered from ante-mortem tooth loss.

As was the case for the Bronze Age skeletons (Section 4.4.7), it was difficult to assess the amount of dental calculus (mineralized plaque) present on the teeth. Where calculus was observed, it was generally slight. The only exceptions were female Burial 2, who had moderate to heavy calculus on her left mandibular molars and moderate on her right maxillary molars, and male Burial 9, who also had heavy calculus on the left mandibular molars (categorization after Brothwell 1981).

No dental enamel hypoplasia was observed on any of the teeth.
Degenerative joint disease Burial 2 was the only Iron Age individual to show signs of spinal joint disease and these were only slight, present in the first and second cervical vertebrae (although those were the only two vertebrae preserved in that skeleton).

\subsubsection{Catalogue}

\section{Skeleton number: 1}

Preservation: Very poor. Just a few degraded fragments of bone and tooth enamel. $<5 \%$ complete. Moderate surface erosion.

Elements present: Cranial: Left temporal.

Dentition: Loose fragmented crowns, mostly unidentifiable except for right maxillary canine, and left maxillary canine and lateral incisor.

Post-cranial: Small fragments of upper limb and unidentified long bone, articular facets from three vertebrae, rib fragments $\times$ five.

Age at death: Amount of wear on surviving tooth crowns suggests age of $30+$ years (judging from attrition patterns in others).

Sex: Unknown.

Stature: Unknown.

Pathology: None observed.

Non-metric traits: Not observable.

Additional info: Considerably less bone survived than originally catalogued. Various fragments previously sent for dating (GU-1149).

\section{Skeleton number: 2}

Preservation: Poor. 20\% complete, very fragmentary with moderate surface erosion.

Elements present: Cranial: Left and right mandible (right menton only), left frontal and parietal, left and right occipital, temporal, sphenoid, maxilla and nasal bones, left zygoma, fragments of ethmoid and vomer.

Dentition: All maxillary and mandibular dentition except right mandibular third molar.

Age at death: 25 to 30 years.

Sex: Female.

Stature: Unknown.

Pathology: Dental disease, slight spinal joint disease.

Non-metric traits: Right mastoid foramen extra-sutural, left accessory supra-orbital foramen, posterior atlas bridging. Additional info: 'Tibiae' (right and left?) previously sent for C14 dating (GU-1404).

\section{Skeleton number: 3}

Preservation: Very poor. $<10 \%$ complete. Fragments only. Moderate surface erosion.

Elements present: Post-cranial: Left humerus and ulna, fragments of unsided humerus, ulna, femur, tibia and rib. One fragment of rib could be identified as right. One unidentified tarsal bone, one hand phalanx, ten fragments of vertebra, including lumbar and thoracic.

Age at death: Adult (30+ years based on vertebrae).

Sex: Unknown.

Stature: Unknown.

Pathology: None observed.

Non-metric traits: None observable.

Additional info: 'Assorted' fragments previously sent for C14 dating (GU-1405).

Skeleton number: 6

Preservation: Poor. 20\% complete, very fragmentary. Moderate surface erosion.

Elements present: Post-cranial: Fragments of sternal 
body, right clavicle, left humerus, ilium, ischium, right femur, fragments of right and left tibia, left ribs $\times$ three, left 1st metacarpal and 3rd metatarsal, three fragments of vertebra.

Age at death: Adult (25+ years).

Sex: Male.

Stature: Unknown.

Pathology: None observed.

Non-metric traits: Right plaque.

Additional info: Left femur previously sent for C14 dating (GU-1410).

\section{Skeleton number: 7}

Preservation: Very poor. $<5 \%$ complete. Several fragments only. Moderate surface erosion.

Elements present: Cranial: right and left temporal bones. Post-cranial: Fragments of unsided femur, tibia, unidentified long bone and calcaneus.

Age at death: Probable adult.

Sex: Unknown.

Stature: Unknown.

Pathology: None observed.

Non-metric traits: None observable.

Additional info: None.

\section{Skeleton number: 8}

Preservation: Very poor. $<5 \%$ complete. Several fragments only. Moderate surface erosion.

Elements present: Cranial: Left mandible, left and right occipital, left temporal.

Dentition: All left and right maxillary and mandibular premolars and molars. The teeth were all loose and with the exception of the right mandibular second molar, crowns/enamel only.

Post-cranial: One cervical vertebra, and one fragment of unidentified vertebra.

Age at death: 18 to 25 years.

Sex: Unknown.

Stature: Unknown.

Pathology: None observed.

Non-metric traits: Left double anterior condylar canal.

Additional info: A label on the box stated 'fragments except for skull removed for C14'. No C14 dates are known to have been obtained previously.

\section{Skeleton number: 9}

Preservation: Poor. 25\% complete. Fragmentary with moderate surface erosion.

Elements present: Cranial: Mandible, occipital, temporal, zygoma, maxilla, palatine.

Dentition: All left mandibular premolars and molars. Loose right maxillary second and third molars, left maxillary lateral incisor and right mandibular second premolar and second molar. All loose teeth were crowns/ enamel only.

Post-cranial: Right clavicle and humerus, left ulna, right and left ilium and ischium, left femur and tibia, right scaphoid, capitate and 1st and 2nd metacarpals, hand phalanges $\times 6$, six cervical and five sacral vertebrae.

Age at death: 30 to 40 years.

Sex: Male.

Stature: Unknown.

Pathology: None observed.

Non-metric traits: Left foramen of Huschke, mastoid foramen extrasutural, posterior condylar canal open and absent zygomatico-facial foramen, precondylar tubercle, double atlas facets.

Additional info: Femoral head previously removed for C14 dating (GU-1412).

\section{Skeleton number: 12}

Preservation: Very poor, fragments of cranium and dentition only. 5\% complete. Moderate surface erosion. Elements present: Cranial: Left mandible, frontal, temporal, sphenoid and maxilla.

Dentition: All right maxillary teeth, left maxillary premolars and first and second molars, all left mandibular teeth except lateral incisor (lost pm), right mandibular central incisor, canine, both premolars and first and second molars. Only right mandibular teeth in situ.

Age at death: 28 to 35 years.

Sex: Possible male.

Stature: Unknown

Pathology: Dental disease.

Non-metric traits: None observable.

Additional info: None.

\section{Skeleton number: 13}

Preservation: Very poor. $<10 \%$ complete. Very fragmentary with severe surface erosion.

Elements present: Cranial: Left and right occipital, right petrous temporal.

Dentition: All dentition loose. Right maxillary lateral incisor, both premolars, second and third molars, left maxillary canine, both premolars and second and third molars, right mandibular premolars and 2nd molar, left mandibular premolars and second molar.

Post-cranial: Unsided scapula, humerus and fibula, right tibia, unsided fibula, minimum number of seven left ribs and two right, seven thoracic vertebrae, plus fragments of neural arch, three further fragments of unidentified vertebra.

Age at death: 25 to 35 years.

Sex: Probable female.

Stature: Unknown.

Pathology: None observed.

Non-metric traits: None recordable.

Additional info: 'Leg fragments' previously removed for C14 dating (GU-1414).

Skeleton number: 14

Preservation: Very poor. $<5 \%$ complete. Only four fragments with moderate-severe surface erosion.

Elements present: Post-cranial: Right radius, ulna and femur.

Age at death: Adult.

Sex: Possible female.

Stature: Unknown.

Pathology: None observed.

Non-metric traits: None observable.

Additional info: None.

\subsection{Stable isotopes from the human and faunal remains by Mandy Jay}

Skeletal material from Dryburn Bridge has been included in a wider project employing carbon and nitrogen stable isotope analysis of bone collagen to investigate Iron Age diet in Britain. The data from the project as a whole will be published elsewhere. The site was chosen as one of four which are geographically close and from which a number of humans and also faunal material were available. The latter is important in providing a 'baseline' for the human values, since local environmental conditions will affect interpretation of the data. The other East Lothian sites from which material has been analysed are Broxmouth (Hill 1982a), Winton 
House and Port Seton (Dalland 1991; Haselgrove \& McCullagh 2000). These four sites were considered of particular importance in respect of their coastal location, as one of the research questions for the study was the consideration of the level of marine foodstuffs in the diet.

Samples were originally taken from ten humans, two of which were Bronze Age. Collagen preservation for this site was poor and only six of the ten yielded acceptable results. These are presented in Table 18 and illus 64, the latter also including the faunal data. Burials 5 (Bronze Age), 7 and 13 produced collagen with $\mathrm{C}: \mathrm{N}$ ratios outside the range considered acceptable for uncontaminated material (2.9 to 3.6), while Burial 12 was not well enough preserved to produce enough collagen for analysis. For the four cattle and the sheep (representative of the herbivores from the site) the average $\delta^{13} \mathrm{C}$ and $\delta^{15} \mathrm{~N}$ values were $-21.8 \pm 0.1 \%$ and $5.8 \pm 1.0 \%$, respectively. The horse has not been included in these averages, since this animal regularly produces depleted carbon values when compared to cattle and sheep and this is likely to indicate physiological disparity.

The $\delta^{13} \mathrm{C}$ values from this study compare well with those produced by the radiocarbon dating process (Table 7; Table 11), except in the case of Burial 8. Analytical error for the data presented here is considered to be $\pm 0.2 \%$ (1-sigma) for both carbon and nitrogen and all data are based on the average of two replicates. The collagen extraction procedure underlying these data includes the use of ultrafilters (Brown et al 1988; Ramsey et al 2004), while the radiocarbon procedure did not (Gordon Cook, pers comm). This filtering may remove additional contaminants, which may be particularly relevant where consolidants have been applied, as in this case. Burial 8 has been included in this analysis as an Iron Age individual, as it was originally classified based on the archaeology, but the radiocarbon date suggests that it is younger than the others presented here (although there are questions over the reliability of the date, Section 7.6).

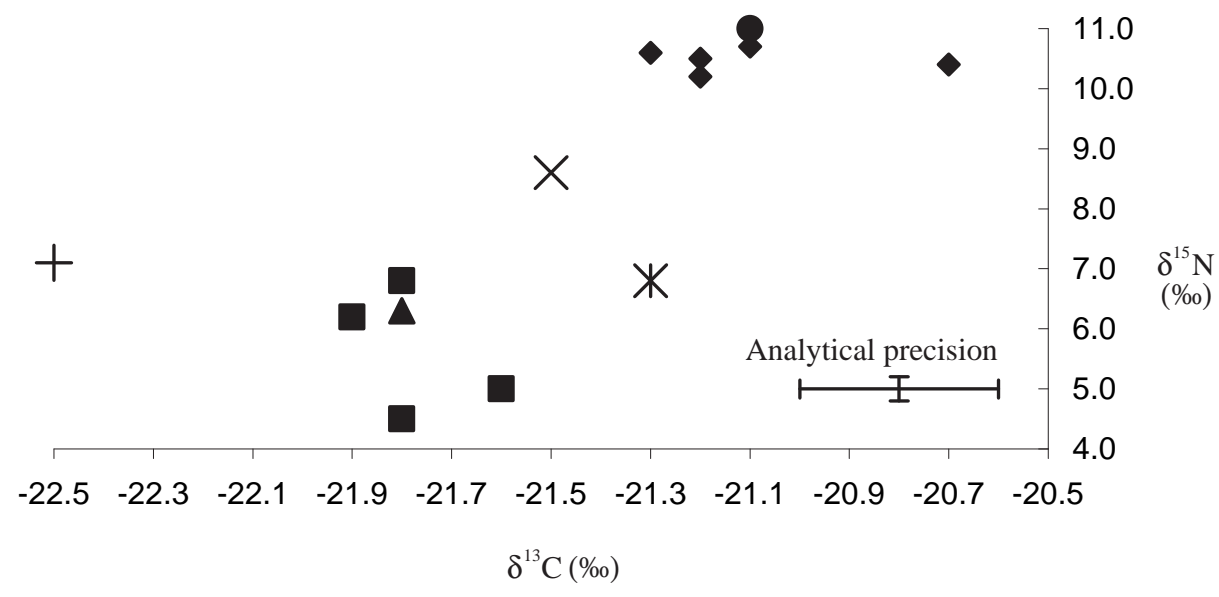

IA Humans $\bullet$ BA Human $\boldsymbol{D}$ Cattle $\boldsymbol{\Delta}$ Sheep $\times$ Dog $\boldsymbol{*}$ Pig + Horse

Illus 64 Stable isotope values plotted for individual humans and fauna

Table 18 Isotopic results for human samples

\begin{tabular}{|c|c|c|c|c|c|}
\hline Burial (skeletal element sampled) & $\delta^{13} \mathbf{C}(\%)$ & $\delta^{15} \mathbf{N}(\% o)$ & C:N (atomic) & $\% \mathrm{C}(\mathrm{wt})$ & $\% \mathbf{N}(w t)$ \\
\hline 10 (Bronze Age) (rib) & -21.1 & 11.0 & 3.3 & 45 & 16 \\
\hline 2 (long bone cortex) & -21.2 & 10.2 & 3.4 & 44 & 15 \\
\hline 6 (long bone cortex) & -21.3 & 10.6 & 3.5 & 42 & 14 \\
\hline 8 (skull) & -21.1 & 10.7 & 3.3 & 44 & 15 \\
\hline 9 (long bone cortex) & -20.7 & 10.4 & 3.4 & 29 & 10 \\
\hline 14 (long bone cortex) & -21.2 & 10.5 & 3.6 & 42 & 14 \\
\hline Average Iron Age & -21.1 & 10.5 & & & \\
\hline Standard deviation & \pm 0.2 & \pm 0.2 & & & \\
\hline
\end{tabular}


Sample numbers here are low, but the conclusions reached take into account results from the other sites which have been included in the overall study. Despite the coastal location of the East Lothian sites, no significant levels of marine foodstuffs were present in the diet at any of them. This suggests deliberate avoidance of this resource. At Dryburn Bridge, the spacing between the average Iron Age human $\delta^{15} \mathrm{~N}$ value and that of the herbivores is $4.7 \%$, indicating a diet high in animal protein (meat and/or dairy produce). A spacing of 3 to $4 \%$ is often given as that expected between diet and consumer (eg Sealy 2001), so that a value over $4 \%$ is noticeably elevated. This elevation is not considered to be due to marine resources, as the average of the $\delta^{13} \mathrm{C}$ values is only $0.8 \%$ less negative than that of the herbivores, such a shift being indicative of one trophic level in the terrestrial system. Human diet is consistent, both across the small number of individuals from this site and from the other sites investigated. The values for the dog and the pig, while being only single individuals here, conform to an overall pattern seen in which adult pigs are largely herbivorous, apparently not being fed significant amounts of animal waste protein, and dogs are omnivorous, probably consuming less animal protein than the human populations. The single Bronze Age human from this site has a slightly enriched nitrogen value over those for the Iron Age, although the numbers of individuals involved here does not allow for this to be considered significant. 


\section{Radiocarbon Dates from the Iron Age Settlement}

The results of the radiocarbon dates have been described where appropriate in the site description. However, a brief appraisal of the group as a whole is merited, to investigate what information they may impart as to site phasing as a whole. The determinations are sorted by group in illus 65 , with the original Glasgow University dates omitted, a result of their long calibrated ranges, except where no corroboration is available from more recent determinations (GU-1285).

The key points to note from comparisons between different dated elements of the settlement are that:
- The dates from Houses 2 and 9 are not statistically different, and thus the buildings could be contemporary constructions. The dates indicate that Houses 2 and 9 were most probably constructed prior to 400 cal BC. House 2 may also have been rebuilt and enlarged prior to $400 \mathrm{cal}$ $\mathrm{BC}$, although the possibility of reuse of old wood from the original building within the secondary structure renders this less certain.

- The cemetery was also in use prior to 400 cal BC and, with one exception, the radiocarbon dates are indistinguishable from those obtained from

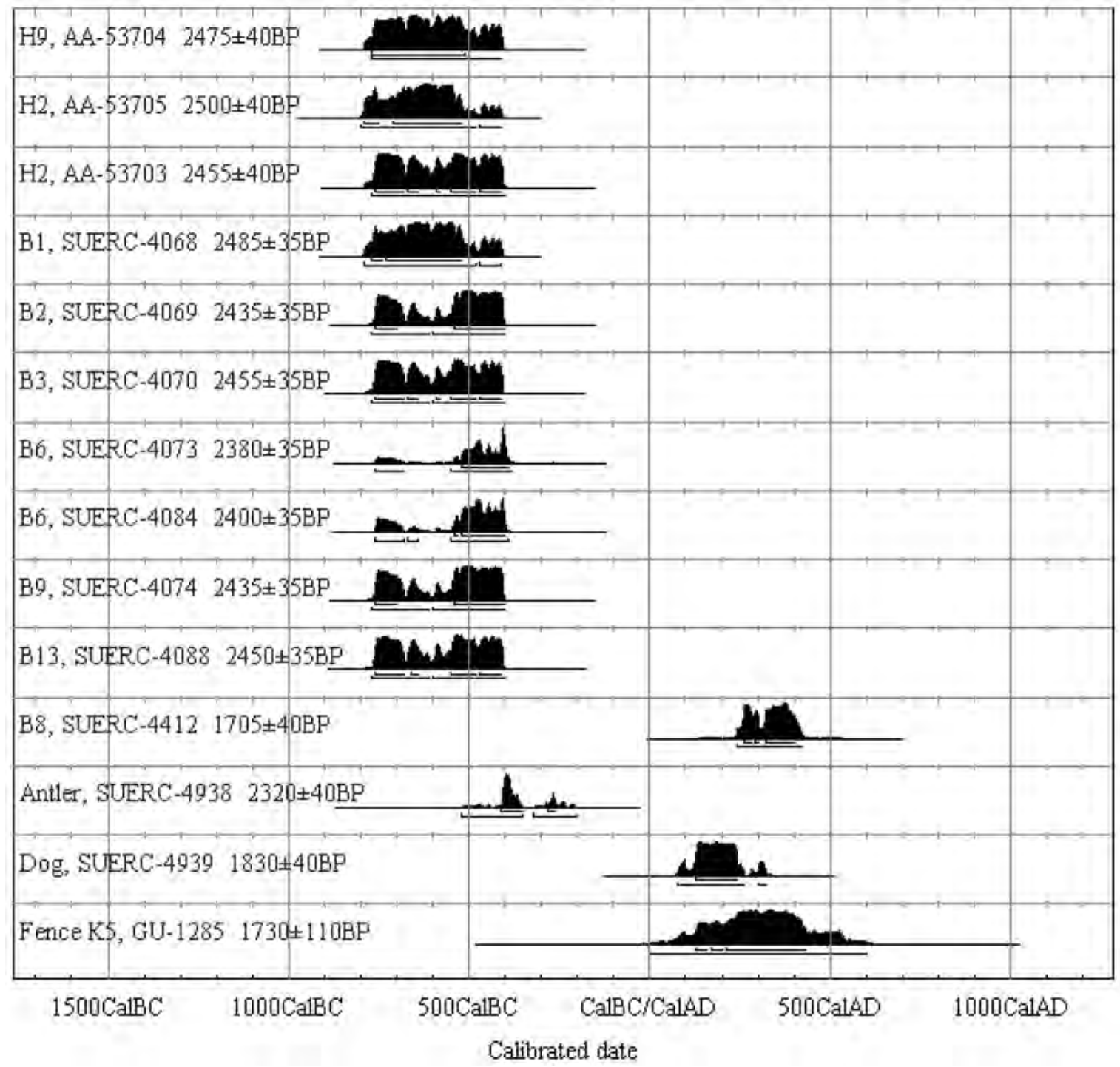

Illus 65 Radiocarbon dates (OxCal v 3.5; Bronk Ramsay 2000) 
Houses 2 and 9. The date from Burial 8 (SUERC4412 ) is several centuries younger those obtained from other burials, although there are good archaeological reasons for doubting the reliability of this determination (discussed in Section 7.6).

- The dates from Burials 1 and 13 are important, as stratigraphic evidence indicates that they were interred before (Burial 13) and after (Burial 1) the removal of the outer enclosure palisade. This provides proxy evidence that the outer enclosure palisade was dismantled prior to $400 \mathrm{cal} \mathrm{BC}$.

- The radiocarbon date from the antler recovered from pit O48 (SUERC-4938) has a calibrated range that partly overlaps with those from both Houses 2 and 9 and the reliably dated burials, and could relate to later occupation of the settlement.

- The date from the fence outside House 7 (GU1285), although with only a wide calibrated range, is statistically later than those from Houses 2 and 9 , the reliably dated pit burials, and the antler from pit O48. It indicates that activity on the settlement site continued into the first millennium cal AD.
- The dog burial took place in the early first millennium cal AD (SUERC-4939). The radiocarbon date is consistent with that obtained from the House 7 fence nearby, but is statistically more recent than those from Houses 2 and 9, all the reliably dated burials, and the antler from pit $\mathrm{O} 48$.

Therefore, certain elements of the site can be placed into a chronological sequence on the basis of the radiocarbon dates, and can contribute towards the development of an overall model of settlement development. The construction of Houses 2 and 9 and the formation of the cemetery could have been contemporary. The cemetery probably formed both before and after the removal of the outer enclosure palisade. The burial of the dog and the date from the House 7 fence-line relate to a chronologically distinct phase of occupation over four centuries after the dated activity related to the cemetery and Houses 2 and 9 . 


\section{The Iron Age Settlement: Discussion}

\subsection{Settlement development and chronology}

Illus 66 presents an outline scheme for the development of the key features of the site, based upon the stratigraphic and spatial evidence presented above, combined with the limited radiocarbon and artefactual dating evidence that is available. The 'phasing' scheme illustrated should not be interpreted necessarily as relating to sudden changes in the plan of the settlement. Rather, the intention has been to identify three groups of broadly co-existing features; assessing whether the change from one to the next reflects gradual evolution or radical re-organization is undertaken separately.

Many excavated features of the site cannot be phased reliably, and thus are excluded from the scheme presented - key amongst these being Houses 4 and 5. Other features, such as the pit graves and the rectangular structures, cannot be linked conclusively to any single phase. The 'phasing' is inevitably a 'best-fit' scheme capable of some revision or refinement.

\subsubsection{Phase I}

This phase is defined by the construction of the more substantial palisaded enclosure. This feature was oval in form, measuring approximately $87 \mathrm{~m}$ by $50 \mathrm{~m}$, and was bounded by a timber fence or palisade. It was provided with two, and possibly three equally spaced entrances on its east side. Two post-ring roundhouses recognized by the excavators (Houses 1 and 6) appear to have been constructed within the north and central interior of the enclosure as part of the original design, and a third likely structure (House 10) recognized by the present author appears to have occupied the south central area. House 1 was the largest of the structures, being at least $14.4 \mathrm{~m}$ in diameter within its wall, whereas House 6 was the smallest, estimated to have been around $9.6 \mathrm{~m}$. House 1 was refurbished during its use-life. The overall scale and character of the proposed primary settlement morphology is not unlike that envisaged for the settlement he excavated at Staple Howe, North Yorkshire (Brewster 1963, esp fig 6).

The original layout of the palisaded enclosure and Houses 1 and 6 was carefully planned. The entrance to House 1 was aligned on the north-east entrance to the outer enclosure, and that for House 6 may have been similarly aligned on a central entrance, although the presence of that feature remains unproven but was suspected. House 10, if its former existence is accepted, was aligned on the south-east entrance of the outer enclosure. The alignment of house and enclosure entrances is not uncommon, and for example is paralleled in the Late Bronze Age enclosed site at Springfield Lyons, Essex (Buckley 1988). The unity of the primary design of outer enclosure and post-ring structures is further strengthened by the recognition that the three structures were laid out in a row. It is apparent from the site plan (illus 3 ) that the structures are strung out on a broad north-east/south-west alignment. However, the precision of the design is not immediately recognizable as the roundhouses are of different sizes, but becomes apparent when it is appreciated that the entrance alignments lie on the same north-east/south-west axis. A straight line can be drawn through the posts defining the inner ends of each entrance passage, ie within the post-rings of House 6 (posts L50 and L52) and House 10 (posts O65 and O73) and the inner post-ring of House 1. This alignment is on an orientation almost parallel to the alignment of the section the outer enclosure palisade trench between the south-east and northeast entrances.

The ordered layout of the settlement appears to encode information relating to the relationships between the three roundhouses and, assuming they were dwellings, their occupants. For example the provision of separate entrances could signify the intended independence of each household, albeit one forming part of a community defined by the presence of the palisaded enclosure. The different sizes of the roundhouses could reflect varying social status of their inhabitants, although we should perhaps avoid being deterministic in assuming that the largest building contained the headman of the community and his kin, since the size variations could alternatively reflect differing numbers of inhabitants or some other social factor that cannot be established from the archaeological remains. As is widely accepted, roundhouses could have fulfilled a range of functions, not all simply being domestic residences. Buildings for non-domestic communal use may have been constructed and, while it is possible to conceive that size differences of buildings related to varying functions, there remains no convincing supporting archaeological evidence for non-domestic roundhouses in southern Scotland.

There could be a correlation between the largest roundhouse (House 1) being aligned with the most complex entrance to the outer enclosure, although the greater concentration of features in that entranceway could reflect a more complex structural history being represented in the archaeological record rather than the former presence of a more elaborate entrance structure. The elaboration of the roundhouse entrances, particularly House 1, 


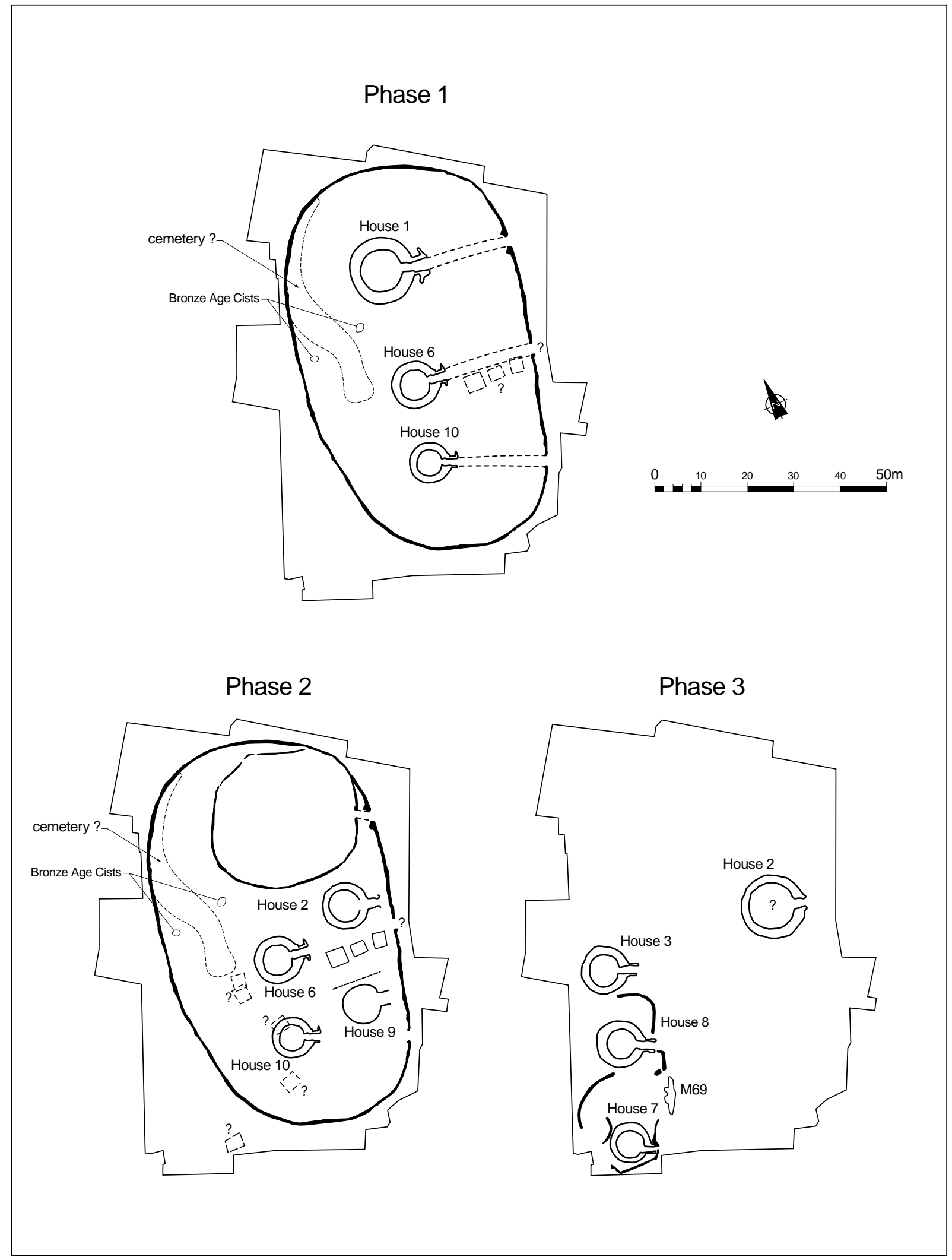

Illus 66 A simplified model for the development of the settlement at Dryburn Bridge

as suggested by their substantial foundations, could indicate an emphasis on the display of wealth and status to those entering the palisaded enclosure. However, issues relating to social status, both within the settlement and between the settlement and others in the contemporary landscape, may be better understood from considering Dryburn Bridge within a local or regional settlement context, which 
is beyond the remit of this report. To the author's knowledge the ordered settlement layout interpreted for Dryburn Bridge is not replicated in any other comparable excavated Iron Age settlement of the Lothian plain.

The cemetery may have begun to form in this primary settlement phase, its location possibly determined by the recognition of the presence of ancient (Bronze Age) burials. Other excavated features may relate to the Phase I layout of the palisaded enclosure, although they may have been secondary additions rather than primary features. These include the rectangular structures aligned to the east of House 6 (and possibly others). Burial 12 appears to have been deliberately positioned outside the entrance to House 6 and at the corner of rectangular structure A. On spatial grounds it seems likely that the deposition of the burial was linked to the presence of one or the other, but the burial has not been dated. Its 'special' status is discussed further in Section 11.6. However, it is equally possible that none of the rectangular structures relate to this primary settlement layout.

No opportunities arose for the independent dating of the outer enclosure or Houses 1, 6 and 10, and the few stratified artefactual discoveries are not informative in chronological terms. The radiocarbon dates from Houses 2 and 9 (Phase II) indicate that it is reasonably certain that the foundation of the palisaded enclosure pre-dates $400 \mathrm{cal} \mathrm{BC}$, and the radiocarbon date from Burial 1 indicates that it had been dismantled, at least in that locality, prior to $400 \mathrm{cal} \mathrm{BC}$. These dates form merely termini ante quem for the date of foundation and longevity of use of the outer enclosure, and provide no positive dating evidence. At best they do not contradict a likely early/mid first millennium BC date for the palisaded enclosure, a chronological context often proposed for this settlement form (Harding 2001; discussed further in Section 11.2)

It is worth considering that, although the palisaded enclosure has been attributed to Phase I, the theoretical possibility exists that it did not form the primary element of the Iron Age settlement at this location. That there was nothing stratigraphically earlier than the palisaded enclosure or Houses 1 and 6 has been described above. To assert the presence of settlement remains pre-dating the palisaded enclosure would thus require special pleading, and in the author's opinion appears unjustified. However, there are unphased features, such as House 5 and fence-line (e), which have an uncertain relationship to all other elements of the site. It is reasonably certain, however, that there was no coherent, archaeologically detectable, settlement layout pre-dating the construction of the outer enclosure and contained post-ring structures. Some tenuous support for the primacy of the palisaded enclosure lies in the absence of any reused worked stones, particularly querns, within the packing of the foundation trench, which may be significant as such items occurred frequently in other features relating to the later occupation of the site.

\subsubsection{Phase II}

A second settlement layout can be detected within the palisaded enclosure, superimposed over the original design. In the northern interior, House 1 was removed and replaced with the inner enclosure. This was fitted into the north-east corner of the outer enclosure, its eastern side set on a separate alignment from that of the outer enclosure, creating an oblique entrance passage between the two. Direct access between the inner enclosure and the remainder of the outer enclosure to the south appears to have been barred off. The resetting of the outer enclosure entrance is likely to have occurred at this time. The foundation trench for the inner enclosure was less substantial than that of the palisaded enclosure, and contained little stone-packing, suggesting that the inner enclosure was bounded by a less substantial fence or stockade than the outer. Given its morphology and the apparent absence of internal features, the inner enclosure may best be interpreted as a stock pen. Phosphate spot tests taken in a transect across the site returned higher readings from within the inner enclosure than from outside it, which might be attributed to the result of stock penning. However, given the prolonged use of the site, any conclusions drawn from a single transect must be treated with extreme caution. The report on the phosphate analysis forms part of the site archive.

Houses 2 and 9 were erected within the outer enclosure, quite possibly at the same time as part of a major reorganization and as a replacement for House 1, although there is no direct stratigraphic evidence for this, and the radiocarbon and artefactual dating is too imprecise to provide support. House 2 in its original form appears to have been a ring-ditch structure approximately $10 \mathrm{~m}$ in diameter, and House 9 was a smaller construction around $6 \mathrm{~m}$ across. In both cases the walls of these structures were defined by ring-groove foundations. Radiocarbon dates obtained from Houses 2 and 9 tend to indicate that these buildings were constructed prior to $400 \mathrm{cal} \mathrm{BC}$ (assuming that the structural timbers dated were not reused old wood). House 2 appears to have been occupied for a prolonged period. At some stage it was enlarged, and was modified thereafter on at least one occasion. It is possible that these changes to House 2 occurred after the removal of the outer enclosure palisade, a point that is returned to in Section 11.1.4.

While Houses 2 and 9 were fitted into unoccupied spaces within the palisaded enclosure, it is evident that their precise siting was carefully organized. It is considered highly likely, though beyond absolute proof, that House 2 in its original form was positioned so as not to intersect the approach to House 6 . If accepted, this suggests the continued existence 
of House 6 , which in turn implies a continuity of settlement between Phases 1 and 2. A similar spatial relationship could be inferred between Houses 10 and 9.

The case for proposing House 2, House 9 and the inner enclosure as contemporary elements of the settlement is considerably strengthened with the recognition that the entrances to these three buildings lie on exactly the same north-east/south-west axis. A line can be drawn through the posts defining the entrances in House 9 (posts L109 and L112), House 2 (terminal posts of the inner ring-groove) and the inner enclosure (posts in palisade terminals). This arrangement is very similar to the relationship between the entrances to the Phase I structures as interpreted above. The particular reasons underpinning the creation of what was effectively a frontage cannot be reconstructed. However, the alignment is more likely to have been ideologically or cosmologically governed than determined on practical grounds, as the effect was the erection of an alignment of structures running obliquely to the east side of the outer enclosure (and thus on a slightly different axis to that of the primary settlement layout, with a difference of $c 6$ degrees). Moreover, the reasons for the slight change in the alignment connecting the doorways, from that evident in the Phase I layout, is equally obscure (and is considered further in Section 11.3.5).

That the location of the new Phase II constructions appears to have been governed by a pre-determined alignment may well explain the peculiar morphology of the juxtaposed outer and inner enclosures. There seem to be no practical advantages to have been gained from building the inner enclosure oblique to the outer, creating an entrance passage but at the same time requiring the provision of what appears to be a blocking feature adjacent to it, seemingly to prevent internal access between outer and inner enclosure. It would have been far simpler to have continued the south side of the inner enclosure around to the outer enclosure, with both enclosures sharing the same east side and entrance.

Other features of the settlement could have formed part of this settlement layout. Rectangular structures A-C may have been standing at the time. Other rectangular structures, given their morphological similarities to A-C, could also have been in use, although they need not all have been exactly contemporary and some could have been replacements for others. Putative House 10 and rectangular structure $\mathrm{H}$ could not have co-existed. The cemetery was also likely forming during this occupation phase.

\subsubsection{Phase III}

The latest settlement layout which can be distinguished with any clarity relates to the presence of what appears to be an unenclosed settlement of ring-ditch houses (Houses 3, $7 \&$ 8) in the south-west part of the excavation site. Because these structures were located at the edge of the excavation area, it is possible that those features exposed form only part of a more extensive suite, an hypothesis that cannot now be tested by further excavation as limestone quarrying has encroached into this sector of the site.

Houses 3 and 8 overlay the boundary of the outer enclosure, and therefore must have been constructed after it had fallen out of use. The three buildings formed a row, with Houses 3 and 8 spaced approximately $7 \mathrm{~m}$ apart and Houses 8 and 7 located around $12 \mathrm{~m}$ apart. Houses 3 and 8 were of very similar dimensions and character, whereas House 7 was slightly smaller and its structural characteristics were less comprehensible, perhaps as a result of greater plough-truncation. The buildings all had entrances facing south-east although, while the row of houses catches the eye, their doorways are not on an axial alignment as had been the structures of Phases 1 and 2. The significance of this observation is unknown, although it presumably relates to different principles underlying settlement layout. All three structures displayed evidence of rebuilding or refurbishment, suggesting that their occupation was not temporary.

The buildings appear to have been associated with a series of gardens or paddocks defined by composite boundaries comprising fence-lines and pit alignments. The presence of pit-defined boundaries perhaps can be best understood within the extensive landscapes of such features recorded in south-east Scotland (eg Halliday 1982; Macinnes 1984a), one of which at Eskbank, Dalkeith has been dated to the early centuries AD (Barber 1985).

The limited dating evidence for this layout indicates activity continuing into the Roman Iron Age. The evidence most intimately associated with the ring-ditch houses is provided by a single radiocarbon determination from a sample taken from the fence-line associated with House 7 (GU-1285). As discussed in Section 7.7.1, the mixed nature of the dated sample, combined with the uncertain taphonomy of the deposit from which the sample was extracted, present significant problems in assessing what the radiocarbon date means. Its date range covers the first half of the first millennium cal AD. However, Roman Iron Age activity in that part of the site is also attested by the radiocarbon date from the dog burial inserted into the upper fill of feature M69 (SUERC-4939). A piece of Roman bottle glass was also recovered from the fill of feature M69.

The dating evidence available does not relate to the construction of ring-ditch Houses 3, 7 and 8, and could reflect the later or even terminal use of the Phase III settlement layout. The presence of Roman artefacts in terminal settlement contexts occurs widely in the settlement record of southeast Scotland (Hill 1982b, esp 8-12). The absence of rotary querns from Houses 3, 7 and 8, combined with the presence of complete saddle-quern lower stones incorporated in potentially useable positions 
within the paved over ring-ditches of Houses 7 and 8 , could be of chronological significance. In conventional terms saddle-querns are understood to have been replaced by rotary technology from around 200 cal BC (Caulfield 1978). However, it would be unwise to use the generalized model of quern replacement to flesh out the chronology of a particular site ( $\mathrm{cf}$ Armit 1991 on the use of quern replacement as a dating tool for the Western Isles settlement sequence). Moreover, as noted in Section 7.4.4, the saddle-querns may simply have been recycled from elsewhere for use as paving slabs, and their date(s) and place (s) of manufacture may be unrelated to the date of the buildings that formed their final resting places.

There are no other features that can be certainly related to this phase of settlement. The possibility that the construction of these buildings overlapped with the continuing use of House 2 is discussed separately in the following section.

\subsubsection{From enclosed to unenclosed settlement - between Phases II and III}

To summarize, three sequential settlement layouts can be detected with varying degrees of clarity within the excavated remains at Dryburn Bridge. Phases I and II appear to represent a continuous period of settlement within the outer palisaded enclosure. The redesign of the settlement layout may have been a single event, but this is not certain. The Phase II roundhouses appear to have been erected prior to $400 \mathrm{cal}$ BC, although associated settlement could have extended beyond $400 \mathrm{cal} \mathrm{BC}$. All reliably dated burials pre-date $400 \mathrm{cal}$ BC. However, the length of occupation represented by these two phases is not known. It could be expected that a free-standing palisade could not have lasted for any considerable period of time (cf Reynolds 1982, 46), but the possibility of archaeologically invisible repair and replacement needs to be borne in mind.

More opaque still is the history of the Phases II and III occupation of the settlement. Activity on the site persisted into the early centuries cal $\mathrm{AD}$ and overlapped with the Roman occupation/s of southern Scotland, but was it continuous? No straight answer can be provided. The settlement appears to have continued after the dismantling of the outer enclosure palisade, judging by the insertion of Burial 1 across its alignment. Other evidence that can be adduced in support is circumstantial rather than empirical. Judging by its juxtaposition with the outer enclosure and the apparent trampling of the outer enclosure palisade outside its entrance, it is possible that House 2 in its enlarged form continued to stand after the removal of the outer enclosure, but the chronology and longevity of this continuing occupation is unknown. The presence of a rectangular structure (I) outside the outer enclosure could indicate that the erection of such structures persisted beyond the removal of the outer enclosure: its stratigraphic relationship to House 7 was not demonstrated but intuitively the rectangular structure is more likely the earlier of the two. Whether other pre-existing structures also continued to stand after the removal of the outer enclosure is similarly unresolved. It cannot be established when ring-ditch Houses 3, 7, and 8 were erected, and whether House 2 was still standing at that unspecified time. This imprecise evidence allows for the settlement to be either continuously occupied or abandoned for a period during the last centuries cal BC.

Given these uncertainties, it becomes difficult to appreciate the specific context within which the change from an enclosed to an unenclosed settlement took place, and hence what significance should be attached to that development. The general similarities in form and layout between House 2 and Houses 3,7 and 8 could indicate a link between them, and hence favour a model of continuous occupation. However, that evidence is not clinching, or even strong, as it could be observed in contrast that the form of the roundhouse wall of House 2 was different from that interpreted for Houses 3, 7 and 8. Additionally, the fact that House 3 truncated a linear feature (F2) that in turn truncated an earlier burial (B8) could suggest a lack of recognition of the cemetery by the later occupants of the settlement site, although again the evidence is not strong.

However, in citing the Dryburn Bridge sequence as being of fundamental importance to the undermining of the Hownam model of settlement form development (eg Armit 1999a, 70), the assumption of continuous occupation at Dryburn Bridge has been made. If the assumption of discontinuity between Phases II and III were to be accepted, the presence of two chronologically distinct settlements at the same location would be of considerable interest, not least as to how we should interpret the continuity of occupation on unexcavated settlement sites more generally (cf Harding 2001, 357 on Braidwood). However, the Dryburn Bridge sequence would provide neither support for nor rebuttal of the Hownam model, and after revisiting this issue it is concluded that Dryburn Bridge does not have the solidity of evidence previously claimed in support of an anti-Hownam stance. There is sufficient evidence from Broxmouth (Hill 1982a) and elsewhere to reject the Hownam sequence as having any widespread significance (reviewed by Armit 1999a).

\subsubsection{Population growth/settlement expansion}

One consequence of the discontinuous development sequence proposed above is that each settlement layout may have comprised no more than four roundhouses. It becomes difficult therefore to argue that the settlement expanded over time or that it supported a larger population. By contrast, the model of continuous occupation could allow for the physical expansion of the settlement over the former outer enclosure palisaded boundary in the Phase 
III use of the settlement. In turn a greater number of structures might be a reflection of an increasing number of inhabitants (as discussed by Jobey 1974), although to propose this makes assumptions both about the functions of structures as well as consistency of numbers of individuals residing in particular buildings (cf Dunwell 1999, 350 on Edin's Hall). This latter cannot readily be calculated. By way of a cautionary modern analogy, the recent expansion and current shortage of housing stock across Britain is as much a result of different patterns of living increasing numbers of single-parent families, single occupants, second homes - as of population growth or economic growth. This modern situation has no direct relevance to later prehistory beyond demonstrating that patterns of living change with time, and there is no a priori reason to assume that living styles did not alter over the course of the last millennium cal BC.

\subsection{The palisaded (outer) enclosure}

Harding's recent review of the Iron Age palisaded enclosures of south-east Scotland identifies several variant types of palisaded settlements and enclosures characteristic of the mid first millennium cal BC, frequently occurring in association with roundhouses displaying ring-ditch and ring-groove characteristics (Harding 2001, 365). These are the sites that had formerly been understood to form the earliest enclosed phase of the Hownam sequence (eg Ritchie 1970). These sites were proposed as forming a distinct grouping within a more long-lived use of palisaded construction methods, to the extent that Harding (2001) has questioned the usefulness of the term 'palisaded enclosure' as a classificatory term.

The enclosure at Dryburn Bridge is morphologically similar to other putative early Iron Age constructions such as Hayhope Knowe (Piggott 1949), Braidwood (Piggott 1958; Gannon 1999) and the larger enclosure at High Knowes, Alnham (Jobey \& Tait 1966), as well as the more extensively explored site at Myrehead, Falkirk (Barclay 1983). The Dryburn Bridge enclosure was most likely a primary component of that settlement, but this was not the case at Myrehead (Barclay 1983), and possibly also not at Braidwood (Gannon 1999). The structural histories of even this small group of settlements, in as far as they can be reconstructed, are variable and specific, and warn against using the results of one excavation to make generalizing statements. All, however, appear to have been in use by the mid first millennium BC.

Harding has discussed the various possible uses for palisaded enclosures (Harding 2001, 365) homestead, village, ancillary enclosure, hillfort. $\mathrm{He}$ considered Jobey \& Tait's interpretation of the larger palisaded enclosure at High Knowes, Alnham as a village and the smaller as a homestead, pointing to other examples in the Anglo-Scottish Borders, and raised the issue of their social inter-relationships
(Jobey \& Tait 1966). This distinction is pertinent to Dryburn Bridge as a smaller palisaded enclosure, $c$ $35 \mathrm{~m}$ in diameter, is recorded as a cropmark only $c$ $100 \mathrm{~m}$ north of the excavation site (NMRS: NT77NW 30 ), and could have formed a contemporary part of the early Iron Age landscape. This site remains unexcavated, but has recently been subject to geophysical survey in advance of proposed quarrying, revealing two circular enclosures with suggestions of internal features (Discovery Excav Scot 2001, $31)$.

\subsection{Roundhouses}

\subsubsection{Post-ring structures}

The primary structures present in the outer enclosure were post-ring structures of distinctly unequal sizes. House 1 , even at $14.4 \mathrm{~m}$ in diameter based on its conservative reconstruction (Section 7.2.2), was 'substantial' in the sense discussed by Hingley. It represents an example of what is increasingly being recognized as a not uncommon feature of the early Iron Age landscapes of eastern and southern Scotland (Hingley 1992, 27-8). Recently excavated examples of similarly large early Iron Age roundhouses include the dated House 1 at Bannockburn (Rideout 1996) and the double-postring structure approximately $18 \mathrm{~m}$ in diameter at Ironshill East, Angus (McGill 2003), both located centrally within palisaded 'homestead' enclosures, in the latter case with the entrances to building and enclosure aligned.

House 6 appeared to be smaller version of House 1 , with an estimated ground floor space $(72 \mathrm{sq} \mathrm{m})$ less than half that of House 1 (163sq m); or less than a third if the larger $18 \mathrm{~m}$ diameter reconstruction is accepted (254sq m). Potential explanations for the varying sizes of the post-ring buildings have been considered above (Section 11.1.1).

\subsubsection{Ring-ditch buildings}

Only following the Dryburn Bridge and Broxmouth excavations was the recurrent presence of ring-ditch houses within south-east Scotland considered in terms of their chronological (Hill 1982b) and functional (Reynolds 1982) significance. Hill noted that ring-ditch houses were well established in southeast Scotland by the mid-first millennium cal BC, on the basis of dated structures from Broxmouth (Hill 1982a) and Douglasmuir, Angus (Kendrick 1995), as well as House 2 at Dryburn Bridge. More recent excavations have extended the currency of the form back into the second millennium cal BC, on the basis of a dated structure from Kintore, Aberdeenshire (Alexander 2000; M Cook, pers comm) and forwards towards the later first millennium cal BC and beyond (Ironshill, Angus: Pollock 1997; Culhawk Hill, Angus: Rees 1998). It is with the understanding of 
this extended chronology for ring-ditch houses that the association of the radiocarbon date from the fence-line of House 7 (GU-1285) with the occupation (although not the construction) of the building itself becomes less startling. Furthermore in this light, the interpretative possibility that the ring-ditch houses at Dryburn Bridge were not all contemporary foundations does not appear problematic.

Ring-ditches were initially interpreted as designed for cattle-stalling (Jobey \& Tait 1966; Reynolds 1982). The ring-ditches at Douglasmuir have more recently been interpreted as constructed for crop storage and comparable in function to souterrains (Kendrick 1995). There is no reason why the functions of ring-ditches could not have varied between structures, settlements or regions, or why particular features could not have had multiple functions (cf Harding 2001, 368). The contrast between the relatively deep-cut features present at Douglasmuir, for example, and the shallow interconnected scoops present at Braidwood and High Knowes, Alnham has been considered previously (Reynolds 1982), and it seems unlikely that both could have been intended to serve the same purposes, whatever they may have been. At Dryburn Bridge both types are present within House 2. The features characterizing Houses 3, 7 and 8 are fairly shallow, although this may be partly a result of plough-truncation - it is notable that the deepest feature, in House 2, was preserved in the only environment where positive archaeological features were preserved on the floor level of a building. The scarcity of hearths from the ground floors of excavated ring-ditch structures (as noted by Ralston 1996, 146) hinders interpretation of their function as domestic structures, but may simply reflect a lack of archaeological survival.

It is noteworthy that the ring-ditches at three of the four structures containing such features were filled in and at least partly paved over. Their infilling in most cases was demonstrated to be a secondary act, and was clearly not part of the initial design of the ring-ditch. If one intention of the excavation of the ring-ditch had been to provide additional headroom under the eaves, then the filling in of the features may have been a significant act. The ring-ditch fills were not sampled and this has not allowed their potential functions to be assessed by palaeobotanical or soil micromorphology studies. In this respect Dryburn Bridge is representative of the excavated data set of ring-ditch houses as a whole. Until the contents of one or more ring-ditch are assessed scientifically and produce meaningful results, our discussions of the specific functions of these features are little more than speculation.

\subsubsection{Ring-groove construction}

House 9 was a small, single-ring roundhouse defined by a post-ring partly embedded in a ring-groove foundation. The use of ring-groove wall foundations in timber roundhouses is a construction device, and their presence cannot be used to define a particular building style or function. The use of this foundation technique is not chronologically sensitive, and can be traced running from the unenclosed settlements of the middle second millennium cal BC (for example Ednie, Peterhead: Strachan \& Dunwell 2003; Lintshie Gutter, Upper Clydesdale: Terry 1995), throughout the first millennium cal $\mathrm{BC}$ and into the Roman Iron Age (for example Camelon: Proudfoot 1978). House 2 at Dryburn Bridge also incorporates ring-groove wall foundations.

\subsubsection{Houses as cultural and chronological indicators?}

This sub-heading paraphrases Hill, who proposed that different types of roundhouse might be chronologically distinct (Hill 1982b, 7), drawing a particular distinction between ring-ditches and houses in the 'Votadinian tradition' (Hill 1982c). At Dryburn Bridge the post-ring buildings pre-dated the appearance of ring-ditch buildings, although the two appear to have co-existed during the Phase II settlement layout. The wider significance of this relationship is uncertain.

The absence of houses of 'Votadinian' style from Dryburn Bridge is of interest, given that these are regarded by Hill as a vernacular style of the late first millennium cal $\mathrm{BC}$ and early first millennium cal AD (Hill 1982b),. At Broxmouth (Hill 1982a) and St Germains (Alexander \& Watkins 1998) such structures were associated with the latest phases of occupation, and appeared to have continued in use into the Roman Iron Age, to judge from the recovery of Roman artefacts at those sites. Given the presence of Roman material at Dryburn Bridge, its association with continued occupation of ring-ditch houses appears likely and suggests that at some sites, of which Dryburn Bridge is one, this style of timber building continued in use while elsewhere 'Votadinian' structures may have become the norm. This is the simplest explanation based upon the evidence excavated at Dryburn Bridge: to associate the Roman Iron Age activity with stone-floored buildings either not surviving or present outside the excavation area would fall foul of Occam's Razor.

\subsubsection{Orientations and cosmology}

The widespread south-easterly orientation of later prehistoric roundhouse and enclosure entrances is reflected at Dryburn Bridge, and is widely (eg Oswald 1997) but not universally considered to be imbued with cosmological significance. In this regard there is a difference of $c 12$ degrees to be drawn between the entrance orientations of the palisaded enclosure and the roundhouses of Phases I and II and the Phase III structures (Houses 3 and 8; the entrance orientation of House 7 is not certain). Assuming it is 
not entirely coincidental, the change in alignment appears to have chronological significance on the basis of the structural phasing presented. This alteration also appears to correspond with the adoption of less rigidly aligned 'frontages' between the doorways of the Phase III roundhouses. It is of note that the orientation of the roundhouse entrance persists into Phase II despite a slight but noticeable change in the frontage alignment. This tends to indicate a conceptual link between Phases I and II, reinforcing the suggestion that these phases represent continuous occupation. The distinction between Phases I/II and Phase III could be taken to indicate the reverse, although of course not necessarily, as what factors lay behind the observed changes are difficult to reconstruct.

As an adjunct to the above, it is worth considering the alignment of the entrance passage between the inner and outer enclosures. This does not follow the orientation for other Phase I and II entrances. There is no evident practical reason that the inner enclosure could not have been constructed to maintain the same alignment. Thus, we can consider that the decision to alter this alignment was significant and related, for example, either to specific practical functions associated with the inner enclosure, or for unknowable symbolic reasons. As above, these observations assume that the re-alignment was meaningful and not the result of casual and unthinking acts.

\subsection{Rectangular structures}

The interpretation of the function(s) of rectangular post-defined structures within Iron Age settlement contexts has been the subject of much discussion in recent decades (see Section 7.5), but is based mainly on discussion of discoveries in central and southern Britain. Excavations at Danebury have revealed a range of rectangular structures with four-, six- and nine-post foundations comparable to those identified at Dryburn Bridge (Cunliffe 1984). However, there is comparatively little evidence for the construction of rectangular buildings during the pre-Roman Iron Age in Scotland (cf Ralston 2004, 22), although several six-post structures similar to the Dryburn Bridge examples were excavated with the unenclosed settlement of ring-ditch houses at Douglasmuir, Angus (Kendrick 1995). Other rectangular structures have also been detected within the palisaded enclosure at Myrehead, Falkirk (Barclay 1983), close to a ring-ditch house at Ironshill, Angus (Pollock 1997), within the ditched enclosure at Port Seton East (Haselgrove \& McCullagh 2000,110) and associated with Late Bronze Age ring-ditch houses at Deer's Den, Kintore (Alexander 2000). The fourpost structure at this last-mentioned site has been dated by radiocarbon methods to the early first millennium cal BC, and the settlement associations of the others fall within the same millennium.

Kendrick concluded that the most likely explanation of the Douglasmuir structures was as raised granaries (Kendrick 1995, 64) (comparable in form to the reconstructions based on the rectangular structure excavated at Staple Howe; Brewster $1963,53)$. She argued that this interpretation was supported to a certain degree by the recovery of charred cereal remains from some of the post-holes of one structure. However, the quantity of material mentioned ( $100+$ wheat grains, 15 barley grains and one oat grain; Brewster 1963, 57) is hardly large. In addition, it is not clear how this material supports the interpretation of the structure as a granary, as the material presumably entered the post-holes either before the setting of the post or after its removal (cf Guilbert 1981, 108-9). More generally, the presence of a granary implies the storage of surplus crops, whereas charred cereal remains reflect primarily crop-processing activities.

Without any positive archaeological evidence it is not possible to be confident in interpreting the particular functions of the Dryburn Bridge structures, which need not have been contemporary (and indeed structures D and E cannot have been). At least some could well have been raised timber granaries, with the implications that such an interpretation carries for the storage of surplus agricultural produce. If this interpretation were accepted, it would remain the case that archaeological evidence for this form of storage technology is relatively rare in the later prehistoric settlement record of eastern Scotland, an area in which grain storage pits (sensu Reynolds 1974) are also very rare, if not wholly absent. The archaeological evidence from eastern Scotland does not seem to represent the sort of large-scale 'centralized storage' seen in southern England at some sites such as Danebury (Gent 1983; Hill 1996, 97-8 for a critique).

It is also of potential interpretative significance that the rectangular structures were founded variously on four-, six- and nine-post arrangements. This may indicate that the foundations were designed with different load-bearing capacities and hence were intended to fulfil different functions. For example, the possibility that structure G represents an excarnation platform associated with the nearby Early Bronze Age burial cists has been considered previously (Section 6.2), but an Iron Age origin could also be advanced (cf Carr \& Knüsel 1997).

\subsection{Souterrain-related features}

Two features were excavated which bear resemblance to the more modest forms of souterrain excavated at sites such as Dalladies (Watkins 1980) and Dubton Farm, Brechin (Cameron 2002). Souterrains are more characteristic of north-east Scotland (Armit 1999b, 577-8), although an example has been confirmed recently in the Upper Forth Valley (Discovery Excav Scot 1999, 88). Until recently they were not known to occur commonly south of the Forth, and most of those that were known were stone-built constructions of relatively grand scale 
and Iron Age date (Welfare 1984). Aerial photography is beginning to rectify this imbalance, with roundhouses associated with souterrains identified in East Lothian (D Cowley, pers comm) and as far south-west as Galloway (Garphar: Cowley \& Brophy 2001, 65, 68)

Of the two potential souterrain-related features at Dryburn Bridge, one was cut into the uppermost floor surfaces of House 2, and may be related at the earliest to its final stages of occupation. The other appears to have been associated with the Phase III settlement layout, and contained a sherd of Roman bottle glass. Both these features thus relate to the later stages of occupation at the site. Roman material has been commonly recovered from souterrain fills in north-east Scotland, and has been argued as dating evidence for a 'souterrain abandonment horizon' in the late second or early third century $\mathrm{AD}$ (Armit 1999b, 587), involving the widespread ritualized infilling and closure of souterrains and possibly the deliberate deposition of Roman artefacts (Armit 1999b, 584-7).

There was no evidence recovered by which the function/s of the Dryburn Bridge features could be determined, although the consensus of opinion is gravitating towards the function of souterrains having been associated with storage of crops and other produce (cf Armit 1999b, 582-3; Alexander 2005).

\subsection{Cemetery}

The excavation of an Iron Age cemetery at Dryburn Bridge represents an important addition to the limited corpus of later prehistoric burial sites of this period from south-east Scotland. Conversely, the Iron Age burial record from this area is rich by comparison to many other areas of Great Britain. Other examples of pit graves include the cemeteries at Broxmouth (Hill 1982a) and Winton House (Dalland 1991), as well as a single example at Port Seton East (Haselgrove \& McCullagh 2000, 125). These single burials, most of which occur in confirmed settlement contexts, appear to contrast with the multiple burials in apparently off-site contexts such as North Belton (Crone 1992) and Lochend (Longworth 1966), and with the 'warrior burials' so-called because of the burial of weaponry with the deceased (eg Dunbar High Street: Roy 2006).

The Dryburn Bridge cemetery contains only ten graves. All but one occupied the north-west part of the settlement, which appears to have been reserved for funerary practices (to judge from the dearth of other archaeological features in that area). The graves surely account for only a small proportion of the inhabitants of the settlement over its period of occupation, and this suggests that most of the dead were disposed of either offsite and/or by means other than burial, such as cremation and the scattering of ashes. The selectivity of who was buried on the site is perhaps emphasized by the absence of children from the cemetery population.

The generally curvilinear distribution of the majority of the graves is noticeable. This might suggest that the arrangement of graves within the cemetery formed some orderly sequence, but this cannot be distinguished within the set of radiocarbon dates. The presence of four graves along the line of the outer enclosure palisade surely reflects an example of the structured deposition of significant deposits along a settlement boundary (reviewed in the Scottish context by Hingley 1992, 31-2), which formed important loci for structured deposition at various stages during the Iron Age (Hingley 1990). This occurrence is paralleled in the burial record elsewhere in Britain (Whimster 1981; Wait 1985), for example nearby at Broxmouth (Hill 1982a, 17980 ), where a cemetery was located outside the Outer Ditch and isolated graves were present at other liminal locations such as the south-west entrance and across a palisade trench. Two of the Dryburn Bridge burials ( 7 and 13) had been placed immediately outside the settlement boundary, a location which must have been carefully chosen to project certain information about the identity, status or means of death of the deceased (cf Bruck 1995). The proximity of the graves to the Early Bronze Age cist burials is also surely more than coincidence.

The archaeological remains of the burial form are relatively simple, each comprising the remains of an individual placed in a crouched position in the base of an unlined pit. The pits were not backfilled with the sand and gravel excavated from them, but were covered directly with stones either imported or reused from elsewhere on the site (such as disused houses or palisade lines). The meaning of this filling material is of course beyond meaningful reconstruction, but its repeated appearance within the graves indicates that it must have been of some significance to the burial rite. It seems possible that the excavated subsoil may have been used to form a low mound over the grave, of which nothing would have survived plough-truncation.

Most of the graves were orientated north/south and, where it could be established, with the bodies facing east, either on their left side with the head to the north (slightly more common), or on the right side with the head to the south. The former is the more common arrangement found in Iron Age burials found in Britain as a whole (Haselgrove 2001, 49), although the variation in arrangements is repeated for instance at Broxmouth (Hill 1982a, 179) and in the East Yorkshire Iron Age square barrow cemeteries (Parker Pearson 1999a, 53). The reasons for this variation in body orientation are not known, but on the basis of the sexed individuals at Dryburn Bridge it does not appear to have been a gender-related distinction (Table 10). The introduction of a sheep molar into Burial 3 and cannel coal working debris and indeterminate animal bone fragments into Burial 2 may well have been unintended. However, given the repeated associations of certain animal 
body parts or bones with male and female burials in East Yorkshire (Parker Pearson 1999a), we should be wary of dismissing the potential link altogether.

Burial 12 stands out from all the others excavated at Dryburn Bridge. The grave lay on a different orientation (north-west/south-east), the inhumed body faced south-west, and it was isolated from the rest of the graves and at what appears to be a significant location within the roundhouse settlement area, outside the entrance to House 6. This burial seems therefore to be a good candidate for a 'special' burial, perhaps a dedicative or commemorative deposit of some kind. However, we should be cautious of arguing for special burials on the basis of orientations of a small number of graves at Broxmouth two of the nine graves within the cemetery area faced west, six east and one north (P H Hill 1995).

No disarticulated fragments of human bone were recovered at Dryburn Bridge, unlike at Broxmouth (P H Hill 1995) where fragments of cranium, postcranial bone and teeth were recovered from a variety of ditches and pits.

\subsection{Economy}

In the light of contemporary excavations then underway at Broxmouth (Hill 1982a), it was initially hoped that, despite it being a plough truncated site, Dryburn Bridge would produce material for environmental analysis (Triscott 1982, 117). In the event no palaeobotanical data was recovered. The mammalian bone assemblage is of limited interpretative value given its generally poor preservation, although the range of domestic species present indicates that livestock played a role in the farming practices adopted by the occupants of Dryburn Bridge throughout its sequence of settlement layouts.

It appears from the combination of ground stone tools, particularly the large numbers of saddlequerns, and the faunal evidence that a mixed agricultural economy was followed. It is not possible to determine with any confidence whether the structural changes in the types and numbers of buildings were matched by changes to agricultural practices.

\subsection{Wealth and status of the settlement}

There is nothing in the limited and mostly prosaic artefact assemblage to indicate that the occupants of Dryburn Bridge were at any stage of high status although, as noted by Hunter (Section 8.9), the assemblage no doubts represents a very partial record of the materials and items that were present on the site during its occupation. The Roman bottle glass is exotic, but similar fragments of Roman material culture have been recovered from a wide range of settlement contexts in southern Scotland (Robertson 1970; Hunter 2001), and their occurrence need not in itself indicate that the settlement was of high status (eg Macinnes 1984b; Macinnes 1989).

The archaeologically visible acts of enclosure and the construction of ostentatious roundhouse entrances could indicate that the occupants of Dryburn Bridge, at least in its original settlement form, were of enhanced status within a local context, but these settlement features could equally have been symbolic boundaries or elements of display ( $\mathrm{cf}$ Collis 1996). Assessment of the wealth and status of a particular site can be investigated reliably only within a regional context, which is beyond the remit of this report.

\subsection{Structured deposition and ritualized acts?}

The disposal of human remains represents one expression of structured deposition at Dryburn Bridge, but are there others? This point is now difficult to assess, however some suggestions can be made.

The insertion of a dog burial into the fill of the souterrain-related feature could have been a deliberate act, in light of the considerable evidence for the structured deposition of animal deposits (summarized by Fitzpatrick 1997, 82), including dogs (eg at Danebury: Cunliffe 1984, 12 and fig 3.8). The potential for the dog burial to have been a 'special animal deposit' (after Grant 1984) is especially pertinent when viewed in light of Armit's proposals for the ritualized destruction and infilling of some of the Angus souterrains (Armit 1999b, 583-6). The dog burial also lies on the circuit of the palisaded enclosure although as this feature may have been dismantled for a considerable time it is not known in this instance whether the superimposition was the result of design or coincidence. The dog appears to have been cherished in life, as it had been allowed to recover from a fractured leg and following death was interred in a carefully stone-floored grave pit. The radiocarbon date for the dog burial is consistent with the Roman glass present within the fill of the souterrain-related feature. Both could have been deposited as part of the closure of that feature, although to propose the Roman glass as a structured ritualized deposit is not justified on archaeological evidence, although it undeniably forms part of the widespread occurrence of Roman material within souterrain fills (cf Armit 1999b). The sickle recovered from the souterrain is more likely to reflect a case of structured deposition than the shard of Roman glass (Section 8.9.2).

Elsewhere, pottery and animal bone recovery from the foundation trench of the palisaded enclosure concentrated at the north-east entrance. Conversely, there was nothing obviously meaningful in the distribution and contexts of the many saddle-querns discovered (cf Hingley 1992, 32). They had for the most part been reused for packing of post-holes or were found within the rubble infill of the House 
2 ring-ditch. Some appeared to have been incorporated into secondary paving within ring-ditch houses (eg Houses $2 \& 7$ ), but do not certainly reflect anything beyond opportunistic reuse. Some of the large artefact-bearing pits interpreted as rubbish pits (eg 048) could have been the focus of acts of structured deposition, but this is now impossible to establish. The recovery of fragments of horse bone from an entrance post-hole in House 6 could also have been a deliberate deposit (Section 9.1.6).
Finally, the scarcity of charred in situ timbers suitable for radiocarbon dating reflects the lack of evidence for deliberate destruction of the built elements of the settlement. However, of the five charred timbers that did survive, four were roundhouse door-posts associated with Houses 2 and 9. It is a matter of conjecture as to whether this can be interpreted as evidence for the selective ritualized destruction of doorways as opposed to the chance by-product of fires. 


\section{Conclusion}

In drawing together the excavation and post-excavation results from Dryburn Bridge, several previously unknown discoveries and themes have come to light since the publication of the interim report in 1982. Principal amongst these have been the proposal of a revised settlement development, based upon the observed stratigraphic, dating and spatial evidence; the identification of planned layouts based upon frontage alignments, and changes to those alignments over time; and the presence of Roman material culture. These have allowed interim statements as to the nature of the site to be reassessed. The outcome is a more detailed picture of the development of one Iron Age settlement in East Lothian. As with any individual site, there are considerable lacunae in the evidence, and it is only through the continued excavation of such sites that a more nuanced impression of the regional development of Iron Age society and settlement will be developed. It is hoped that the results from Dryburn Bridge will contribute to the developing research framework for this region. As noted by Armit, the agenda for south-east Scotland has not really moved on since the late 1970s/early 1980s (Armit 1999a, 73), and is some way behind that of other regions, although recent initiatives such at the Traprain Law Environs Project (Discovery Excav Scot 2002, 43; Discovery Excav Scot 2003, 60-1; Discovery Excav Scot 2004, 46-7) and the Traprain Law Summit Project (Armit et al 2002) are beginning to redress this. Given these developments, and to avoid repeating many of the issues presented in recent regional reviews (eg Armit 1999a; Haselgrove \& McCullagh 2000, 186-9), there is no attempt in this report to work up a 'grand narrative' based upon the revised results (although this risks attracting the opprobrium of Armit 1999a, 72-3).

The final word is reserved for the fate of the settlement. Hill has identified a substantial discontinuity in the settlement record of south-east Scotland which appears to coincide broadly with the successive Roman occupations of southern Scotland in the early centuries AD (Hill 1982b, 10). This pattern occurs repeatedly at excavated settlement sites in the south-east, such as St Germains (Alexander \& Watkins 1998), Broxmouth (Hill 1982a), Port Seton (Haselgrove \& McCullagh 2000) and Dryburn Bridge, although occupation of other high status sites such as Traprain Law (Jobey 1976) and Castle Rock, Edinburgh (Driscoll \& Yeoman 1997) appears to have persisted beyond this. That a severe settlement dislocation occurred seems beyond doubt, and is perhaps mirrored by the apparent disappearance of souterrains in Angus (Armit 1999b). What the precise causes of this disruption were, whether economic, political or social, have been the subject of considerable debate and will continue to stimulate discussion. What were the effects of the abandonments of these sites? What happened to the last 


\section{Acknowledgements}

The excavation work was initially funded by the Scottish Development Department and the writing up by Historic Scotland. With such a large excavation there are numerous people who have made important contributions to the site archive. These include the site directors, Jon Triscott and Dave Pollock, and the supervisors Jim Falconer, Jill Kendrick, Rod McCullagh and Anne Weatherstone. Thanks are due to all the specialist contributors for their reports and for their comments upon other sections of the report. A good deal of the drawing work was originally done by Dave Pollock (illus 3, 4, $9,10,21,24,30,32,36,47,48,54,58-60,61$ (twisted ring)) and was reworked and added to for publication by Kevin Hicks and George Mudie of CFA. Illus
61 (excluding twisted ring) and illus 62-63 were produced by Alan Braby. Remaining illustrations were produced by Kevin Hicks. Louise McGuire undertook the initial sorting of the archive and typing up of the original specialist reports, and Derek Alexander and Bill Finlayson collated that material. Dave Cowley is thanked for providing information on recent discoveries of souterrains in southern Scotland, and Adam Jackson is thanked for sharing his expertise as regards saddle-quern technology. Derek Alexander, Rod McCullagh, Patrick Ashmore and Ian Ralston commented on earlier drafts of the publication. Final responsibility for the report lies with the author and CFA Archaeology. 


\section{References}

Alexander, D $2000^{`}$ Excavation of Neolithic pits, later prehistoric structures and a Roman Temporary Camp along the line of the A96 Kintore and Blackburn Bypass', Proc Soc Antiq Scot 130, 11-75.

Alexander, D 2005 'Redcastle, Lunan Bay, Angus: the excavation of an Iron Age timber-lined souterrain and a Pictish barrow cemetery' Proc Soc Antiq Scot 135, 41-118.

Alexander, D \& Watkins, T 1998 'St Germains, Tranent, East Lothian: the excavation of Early Bronze Age remains and Iron Age enclosed and unenclosed settlements', Proc Soc Antiq Scot 128, 203-54.

Armit, I 1991 'The Atlantic Scottish Iron Age: five levels of chronology', Proc Soc Antiq Scot 121, 181-214.

Armit, I 1997 Celtic Scotland. Batsford, London.

Armit, I 1999a 'Life after Hownam: the Iron Age in south-east Scotland', in Bevan, B (ed), Northern Exposure: Interpretive Devolution and the Iron Ages in Britain, 65-80. Leicester (=School Archaeol Studies monogr 4).

Armit, I 1999b 'The abandonment of souterrains: evolution, catastrophe or dislocation?', Proc Soc Antiq Scot 129, 577-96.

Armit, I \& Braby, A 2002 'Excavation of a burnt mound and associated structures at Ceann nan Clachan, North Uist', Proc Soc Antiq Scot 132, 229-58.

Armit, I, Dunwell, A \& Hunter, F 2002 'The hill at the Empire's Edge: recent work on Traprain Law', Trans East Lothian Antiq Field Natur Soc $25,1-11$.

Ashmore, P J 1999 'Radiocarbon dating: avoiding errors in dating by avoiding mixed samples', Antiquity 73, 124-30.

Ashmore, P J , Cook, G T \& Harkness, D D 2001 Radiocarbon Dates for Archaeological Sites in Scotland Issued Before June 1996. www.historicscotland.gov.uk.

Aufderheide, A C \& Rodriguez-Martin, C 1998 The Cambridge Encyclopaedia of Human Palaeopathology. Cambridge University Press, Cambridge.

Avery, M \& Close-Brooks, J 1969 'Shearplace Hill, Sydling St Nicholas, Dorset, House A: a suggested re-interpretation', Proc Prehist Soc $35,345-51$.

Bachmann, H G 1982 The Identification of Slags from Archaeological Sites. London (=Inst Archaeol Univ London Occ Paper 6).

Barber, J 1985 'The pit alignment at Eskbank Nurseries', Proc Prehist Soc 51, 149-66.

Barclay, G J 1983 'The excavation of a settlement of the Later Bronze Age and Iron Age at Myrehead, Falkirk District' Glasgow Archael J 10, 41-71.

Barclay, G J 1993 'The excavation of pit circles at Romancamp Gate, Fochabers, Moray, 1990', Proc Soc Antiq Scot 123, 255-68.

Barclay, G J \& Russell-White, C J (eds) 1993 ‘Excavations in the ceremonial complex of the fourth to second millennium $\mathrm{BC}$ at Balfarg/Balbirnie, Glenrothes, Fife', Proc Soc Antiq Scot 123, $43-210$.

Bass, W 1995 Human Osteology: A Laboratory and Field Manual. $4^{\text {th }}$ Edition. Missouri Archaeological Society.

Berry, R C \& Berry, R J 1967 'Epigenetic variation in the human cranium', Journal of Anatomy 101, $361-79$

Bersu, G 1940 'Excavations at Little Woodbury, Wiltshire', Proc Prehist Soc 6, 30-111.

Binford, L R 1978 Nunamiut Ethnoarchaeology. Academic Press, New York.

Boessneck, J 1969 'Osteological differences between sheep (Ovis aries Linne) and goats (Capra hircus Linne)', in Brothwell, D \& Higgs, E (eds) 1969, $331-58$

Brain, C K 1981 The hunters or the Hunted? An Introduction to African Cave Taphonomy. University of Chicago Press, Chicago.

Breeze, D J 1974 'The Roman fortlet at Barburgh Mill, Dumfriesshire', Britannia 5, 130-62.

Brewster, T C M 1963 The Excavation of Staple Howe. Dennis \& Sons, Scarborough.

Brock, S L \& Ruff, C B 1988 'Diachronic patterns of change in structural properties of the femur in the prehistoric American Southwest', $A m J$ Physical Anthropol 75, 113-27.

Bronk Ramsey, C 2000 OxCal v 3.5 .

Bronk Ramsey, C 2003 OxCal v 3.9.

Brooks, S T \& Suchey, J M 1990 'Skeletal age determination based on the Os Pubis: a comparison of the Ascadi-Nemeskeri and Suchey-Brooks methods', Human Evolution 5, 227-38.

Brothwell, D R 1981 Digging up Bones, $3^{\text {rd }}$ edition. London.

Brothwell, D R \& Higgs, E (eds) 1969 Science in Archaeology 2. Thames \& Hudson, London.

Brown, T A, Nelson, D E, Vogel, J S \& Southon, J R 1988. 'Improved collagen extraction by modified Longin method', Radiocarbon 30 (2), 171-7.

Bruck, J 1995 'A place for the dead: the role of human remains in later Bronze Age Britain', Proc Prehist Soc 61, 245-77.

Buckley, D 1988 'Springfield', Curr Archaeol 108 (vol 10.1), 6-11.

Buikstra, J E \& Ubelaker, D H (eds) 1994 Standards for Data Collection from Human Skeletal 
Remains.Archaeological Survey Research Series No 44, Arkansas.

Burgess, C 1976'Meldon Bridge: a Neolithic defended promontory complex near Peebles', in Burgess, C \& Miket, R (eds), Settlement and Economy in the Third and Second Millennium BC, 151-79. Oxford (=Br Archaeol Rep, Br Ser 33).

Burley, E 1956 'A catalogue and survey of the metalwork from Traprain Law', Proc Soc Antiq Scot 89 (1955-6), 118-226.

Callandar, R F \& MacKenzie, N A 1991 The Management of Wild Red Deer in Scotland. Rural Forum Scotland, Perth.

Callander, J G 1929 'Scottish Neolithic pottery', Proc Soc Antiq Scot 63 (1928-9), 29-98.

Cameron, K 2002 'Excavation of Neolithic pits and Iron Age souterrains at Dubton Farm, Brechin, Angus', Tayside Fife Archaeol J 8, 19-76.

Carr, G \& Knüsel, C 1997 'The ritual framework of excarnation by exposure as the mortuary practice of the early and middle Iron Ages of central southern Britain', in Gwilt, A \& Haselgrove, C (eds) 1997, 167-73.

Caulfield, S 1978 'Quern replacement and the origin of brochs', Proc Soc Antiq Scot 109 (1977-8), 129-39.

Chalmers, J H 1870 'Notice of the discovery of a stone cist at Broomend, near Inverurie, Abderdeenshire', Proc Soc Antiq Scot 7 (1866-8), 110-14.

Champion, T C \& Collis, J R (eds) 1996 The Iron Age in Britain and Ireland: Recent Trends. Sheffield Academic Press, Sheffield.

Charlesworth, D 1966 'Roman square bottles', Journal of Glass Studies 8, 26-40.

Childe, V G \& Lowe, A 1939 'A Beaker burial from Innerwick, East Lothian', Proc Soc Antiq Scot, 78 (1938-9), 318-19.

Clarke, A 1998 'Stone', in Main, L, 'Excavation of a timber round-house and broch at the Fairy Knowe, Buchlyvie, Stirlingshire, 1975-8', Proc Soc Antiq Scot 128, 377-90.

Clarke, C M \& Hamilton, J 1999 'Excavation of a cist burial on Doons Law, Leetside Farm, Whitsome, Berwickshire', Proc Soc Antiq Scot 129 (1999), 189-201.

Clarke, D L 1970 Beaker Pottery of Great Britain and Ireland. Cambridge.

Close-Brooks, J, Young, A \& Lunt, D A 1979 'A Beaker cist at Skateraw, East Lothian', Trans East Lothian Antiq Field Natur Soc 16 (1979), 1-6.

Clutton-Brock, T H, Guinness, E E \& Albon, S D 1982 Red Deer: Behaviour and Ecology of Two Sexes. Chicago: The University of Chicago Press.

Collis, J 1996 'Hill-forts, enclosures and boundaries', in Champion, T C \& Collis, J R (eds) 1996, 87-94.

Collis, J (ed) 2001 Society and Settlement in Iron Age Europe. J R Collis Publications, Sheffield.

Cook, M 2000 'Excavation of Neolithic and Bronze Age settlement features at Lamb's Nursery, Dalkeith, Midlothian', Proc Soc Antiq Scot 130, 93-113.
Cool, H E M 1982 'The artefact record: some possibilities, in Harding, D W (ed) 1982, 92-100.

Cool, H E M \& Price, J 1995 Roman Vessel Glass from Excavations in Colchester, 1971-85. Colchester (=Colchester Archaeological Report 8).

Cowie, T 1993a 'A survey of the Neolithic pottery of eastern and central Scotland', Proc Soc Antiq Scot 123, 13-41.

Cowie, T 1993b 'Later Neolithic Impressed Ware: vessels P83-P114 (Group 3)', in Barclay, G \& Russell-White, C J 1993, 121-6.

Cowley, D \& Brophy, K 2001 'The impact of aerial photography across the lowlands of south-west Scotland', Trans Dumfries Galloway Natur Hist Antiq Soc 75, 47-72.

Crawford-Adams, J 1987 Outline of Fractures, 9th Edition. Churchill Livingstone, Edinburgh.

Crew, P 1995 'Bloomery iron smelting slags and other residues', Historical Metallurgy Society Archaeology, Datasheet 5.

Crone, B A 1992 'An Iron Age cist at North Belton Farm, Dunbar', Proc Soc Antiq Scot 122, 161-70.

Cunliffe, B 1984 Danebury: an Iron Age Hillfort in Hampshire, Volume 1, the Excavations, 1969 1978: the Site. London (=Council for British Archaeology Res Rep 52).

Curle, A O 1915 'Account of excavations on Traprain Law in the parish of Prestonkirk, county of Haddington, in 1914', Proc Soc Antiq Scot 49 (1914-15), 139-202.

Dalland, M 1991 'Burials at Winton House, Cockenzie and Port Seton, East Lothian', Proc Soc Antiq Scot 121, 175-80.

Davidson, C B 1870 'Notice of further stone kists found at Broomend, near the Inverurie papermills', Proc Soc Antiq Scot 7 (1866-8), 115-18.

DeMaine, M R 1990 'The northern Necropolis at Emona - banquet burials with ladles', Annales du 11e Congrès de AIHV, Basel, 129-44.

Discovery and Excavation in Scotland. Council for Scottish Archaeology, Edinburgh.

Driscoll, S T \& Yeoman, P A 1997 Excavations within Edinburgh Castle in 1988-91. Edinburgh (=Soc Ant Scot monogr 12).

Dunwell, A 1999 'Edin's Hall fort, broch and settlement, Berwickshire (Scottish Borders): recent fieldwork and new perceptions', Proc Soc Antiq Scot 129, 303-57.

Ellison, A \& Drewett, P C 1971 'Pits and post-holes in the British early iron age: some alternative explanations', Proc Prehist Soc 37, 183-94.

Finnegan, M 1978 'Non-metric variation of the infracranial skeleton', J Anatomy 125, 23-37.

Fitzpatrick, A 1997 'Everyday life in Iron Age Wessex', in Gwilt, A \& Haselgrove, C (eds) 1997, 73-86.

Fowler, E 1960 'The origins and development of the penannular brooch in Europe', Proc Prehist Soc 26, 149-77.

Gannon, A 1999 'Challenging the past: the resurvey of Braidwood hillfort', in Frodsham, P, Topping, 
P \& Cowley, D (eds) 'We were always chasing time: papers presented to Keith Blood, Northern Archaeology 17/18, 105-11.

Gent, H 1983 'Centralised storage in later prehistoric Britain', Proc Prehist Soc 49, 243-67.

Gibson, W 1922 Cannel Coals, Lignite and Mineral Oil in Scotland. London, HMSO (=Special Reports in the Mineral Resources of Great Britain, vol 24).

Grant, A 1984 'Survival or sacrifice? A critical appraisal of animal burials in the Iron Age', in Grigson, C \& Clutton-Brock, J (eds), Animals and Archaeology 4: Husbandry in Europe, 2218. Oxford (=Br Archeol Rep, Br Ser 227).

Grauer, A L 1993 'Patterns of anaemia and infection from medieval York, England', Am J Physical Anthropol 91, 203-13.

Greig, D C 1971 British Regional Geology: The South of Scotland. HMSO, Edinburgh.

Greig, M, Greig, C, Shepherd, A N \& Shepherd, I A G 1989 'A Beaker cist from Chapelden, Tore of Troup, Aberdour, Banff and Buchan District, with a note on the orientation of Beaker burials in north-east Scotland', Proc Soc Antiq Scot 119, $73-81$.

Guilbert, G C 1975 'Planned hillfort interiors', Proc Prehist Soc 41, 203-21.

Guilbert, G C 1976 ' Moel y Gaer (Rhosesmor) 1972 1973: an area excavation in the interior', in Harding, D W (ed) 1976, 303-17.

Guilbert, G C 1981 'Hillfort functions and populations: a sceptical viewpoint', in Guilbert, G C (ed), Hillfort Studies: Essays for A H A Hogg, 104-21. Leicester University Press, Leicester.

Gwilt, A \& Haselgrove, C (eds) 1997 Reconstructing Iron Age Societies. Oxford (= Oxbow monogr 71).

Halliday, S 1982 'Later prehistoric farming in south-east Scotland', in Harding, D W (ed) 1982, $75-87$.

Hanley, R \& Sheridan, A 1994 'A Beaker cist from Balblair, near Beauly, Inverness District', Proc Soc Antiq Scot 124, 129-39.

Harding, D W (ed) 1976 Hillforts: Later Prehistoric Earthworks in Britain and Ireland. Academic Press, London.

Harding, D W (ed) 1982 Later Prehistoric Settlement in South-East Scotland. University of Edinburgh, Department of Archaeology, Occasional Paper No 8.

Harding, D W 2001 'Later prehistory in South-East Scotland: a critical review', Oxford Archaeol $J$ 20(4), 355-76.

Harris, J 1984 'A preliminary survey of hut circles and field systems in SE Perthshire', Proc Soc Antiq Scot 114, 199-216.

Haselgrove, C 2001 'Iron Age Britain and its European setting', in Collis, J (ed) 2001, $37-72$.

Haselgrove, C \& McCullagh, R 2000 An Iron Age Coastal Community in East Lothian: The Excavation of Two Later Prehistoric Enclosure
Complexes at Fishers Road, Port Seton, 1994-5. Edinburgh (=Scott Trust Archaeol Res monogr $6)$.

Heald, A 2000 'Metalworking objects and debris' in Haselgrove, C \& McCullagh, R (eds) 2000, 39.

Hedges, J 1975 'Excavation of two Orcadian burnt mounds at Liddle and Beaquoy', Proc Soc Antiq Scot 106 (1974-5), 39-98.

Hesse, B \& Waspnish, P 1985 Animal Bone Archaeology. Taraxacum Press, Washington.

Hill, J D 1995 Ritual and Rubbish in the Iron Age of Wessex. Oxford (=Br Archaeol Rep, Br Ser 242 ).

Hill, J D 1996 'Hill-forts and the Iron Age of Wessex', in Champion, T C \& Collis, J R (eds) 1996, 95-116.

Hill, J D \& Cumberpatch, C G (eds) 1995 Different Iron Ages: Studies on the Iron Age of Temperate Europe. Oxford (=Br Archaeol Rep, Int Ser 602).

Hill, P H 1982a 'Broxmouth Hill-fort excavations, 1977-78: an interim report', in Harding, D W (ed) 1982, 141-88.

Hill, P H 1982b 'Settlement and chronology', in Harding, D W (ed) 1982, 4-43.

Hill, P H 1982c 'Towards a new classification of early houses', Scott Archaeol Rev 1, 24-31.

Hill, P H 1984 'A sense of proportion: a contribution to the study of double-ring roundhouses', Scott Archaeol Rev 3, pt 2, 80-6.

Hill, P H 1995 Broxmouth excavations. Draft excavation report typescript held by Historic Scotland, unpublished.

Hingley, R 1990 'Boundaries surrounding Iron Age and Romano-British settlements', Scott Archaeol Rev 7, 96-103.

Hingley, R 1992 'Society in Scotland from 700 BC to AD 200', Proc Soc Antiq Scot 122, 7-53.

Hingley, R 1997 'Iron, ironworking and regeneration: a study of the symbolic meaning of metalworking in Iron Age Britain', in Gwilt, A \& Haselgrove, C (eds) 1997, 9-18.

Holwerda, J H 1931 Een vondst uit den Rijn bij Doorwert en romeinische sarcophaag uit Simpelveld. Leiden (Oudheidkundige Mededeelingen uits Rijksmuseum van Oudheiden te Leiden Supp. 12).

Hunter, F 1996 'Recent Roman Iron Age metalwork finds from Fife and Tayside', Tayside Fife Archaeol J 2, 113-25.

Hunter, F 1997 'Iron Age hoarding in Scotland and northern England', in Gwilt, A \& Haselgrove, C (eds) 1997, 108-33.

Hunter, F 2001 'Roman and native in Scotland: new approaches', J Roman Archaeol 14, 289-309.

Ingemark, D 2003 Glass, Alcohol and Power in Roman Iron Age Scotland. PhD thesis, Dept of Archaeology and Ancient History, Lund University, Sweden.

Iscan, M \& Loth, S 1986a 'Determination of age from the sternal rib in white males: a test of the Phase Method', J Forensic Science 31, 122-32.

Iscan, M \& Loth, S 1986b 'Determination of age from 
the sternal rib in white females: a test of the Phase Method', J Forensic Science, 31, 990-9.

Isings, C 1957 Roman Glass from Dated Finds. Groningen.

Jackes, M, Lubell, D \& Meiklejohn, C 1997 'Healthy but mortal: human biology and the first farmers of western Europe', Antiquity 71, 639-58.

Jobey, G 1962 'An Iron Age homestead at West Brandon, Durham', Arch Aeliana, 4 ser, 40, 1-34.

Jobey, G 1974 'Notes on some population problems in the area between the two Roman walls, I', Archaeol Aeliana, 5 ser, 2, 17-26.

Jobey, G 1976 'Traprain Law: a summary', in Harding, D W (ed) 1976, 191-204.

Jobey, G 1980 ‘Unenclosed platforms and settlements of the later second millennium $\mathrm{BC}$ in northern Britain', Scott Archaeol Forum 10, 12-26.

Jobey, G \& Tait, J 1966 'Excavations on palisaded settlements and cairnfields at Alnham, Northumberland', Archaeol Aeliana, 4 ser, 44, 5-48.

Johnson, M 1999 'Prehistoric pottery', in Speak, S \& Burgess, C 1999 'Meldon Bridge: a centre of the third millennium BC in Peeblesshire', Proc Soc Antiq Scot 129, 53-76.

Jurmain, R D 1990 'Palaeoepidemiology of a Central Californian prehistoric population from CAALAI', Am J Physical Anthropol 83, 83-94.

Kelly , F 1998 Early Irish Farming: a Study Based Mainly on the Law-texts of the $7^{\text {th }}$ and $8^{\text {th }}$ centuries $A D$. Dublin Institute for Advanced Studies, Dublin.

Kendrick, J 1995 'Excavation of a Neolithic enclosure and an Iron Age settlement at Douglasmuir, Angus', Proc Soc Antiq Scot 125, 29-68.

Kennedy K A R 1989 'Skeletal markers of occupational stress', in Iscan, M Y \& Kennedy, K A R (eds) Reconstruction of Life from the Skeleton, 129-60. Liss, New York.

King, S E 1994 Human Skeletal Remains from the Isle of May. Glasgow GUARD report, unpublished.

Kinnes, I, Gibson, G, Ambers, J, Bowman, S, Leese, M \& Boast, R 1991 'Radiocarbon dating and British Beakers: the British Museum programme', Scott Archaeol Rev 8, 35-68.

Lanting, J N \& van der Waals, J D 1972 'British Beakers as seen from the Continent', Helinium $12,20-46$.

Larsen, C S 1984 'Health and disease in prehistoric Georgia: the transition to agriculture', in Cohen, M N \& Armelagos, G J (eds), Paleopathology at the Origins of Agriculture, 367-92. Academic Press, London.

Lewis, J \& Terry, J 2004 'The excavation of an early Bronze Age cemetery at Holly Road, Leven, Fife', Tayside Fife Archaeol J 10, 25-53.

Longworth, I H 1966 'A massive cist with multiple burials of Iron Age date at Lochend, Dunbar', Proc Soc Antiq Scot 98 (1964-6), 173-97.

Longworth, I H 1967 'Further discoveries at Brackmont Mill, Brackmont Farm and Tentsmuir Fife', Proc Soc Antiq Scot 99 (1966-7), 60-92.

Lovejoy, C O, Meindle, R S, Pryzbeck, T R \&
Mensforth, R P 1985 'Chronological metamorphosis of the auricular surface of the ilium: a new method for the determination of age', $A m J$ Physical Anthropol 68, 15-28.

Lyman, R L 1994 Vertebrate Taphonomy. Cambridge University Press, Cambridge.

McDonnell, G 1986 The Classification of Early Ironworking Slags. Unpublished PhD thesis, Aston University.

McGill, C 2003 'The excavation of a palisaded enclosure and associated structures at Ironshill East, near Inverkeilor, Angus', Tayside Fife Archaeol J 9, 14-33.

McInnes, I J 1969 'A Scottish Neolithic pottery sequence', Scot Archaeol Forum 1, 19-30.

Macinnes, L 1984a 'Settlement and economy: East Lothian and the Tyne-Forth province', in Miket, R \& Burgess, C (eds) 1984, 176-98.

Macinnes, L 1984b 'Brochs and the Roman occupation of lowland Scotland', Proc Soc Antiq Scot $114,235-49$.

Macinnes, L 1989 'Baubles, bangles and beads: trade and exchange in Roman Scotland', in Barrett, J C, Fitzpatrick, A P \& Macinnes, L (eds), Barbarians and Romans in North-West Europe from the Later Republic to Late Antiquity, 108-16. Oxford (= Br Archaeol Rep, Int Ser 471).

MacSween, A 1999 'Wider context of the prehistoric pottery', in Speak, S \& Burgess, C 1999 'Meldon Bridge: a centre of the third millennium $\mathrm{BC}$ in Peeblesshire', Proc Soc Antiq Scot 129, 76-80.

Manchester, K 1989 Bone Changes in Leprosy: Pathogenesis and Palaeopathology. University of Bradford, Bradford.

Manning, W H 1985 Catalogue of the RomanoBritish Iron Tools, Fittings and Weapons in the British Museum. Trustees of the British Museum, London.

Masseroli, S 1998 'Analisi di una forma vitrea: la bottiglia Isings 50 nella Cisalpina Romana', Il Vetro dall'Antichità all'Eta Contemporanea: Aspetti Tecnologici, Funzionali e Commerciali, Milan, 41-9.

Meadow, R H 1980 'Animal bones: problems for the archaeologist together with some possible solutions', Paleorient 6, 65-77.

Metcalf, P \& Huntington, R 1991 Celebrations of Death: the Anthropology of Mortuary Ritual. Cambridge University Press, Cambridge.

Miket, R \& Burgess, C (eds) 1984 Between and Beyond the Walls: essays on the prehistory and history of north Britain in honour of George Jobey. John Donald, Edinburgh.

Miles, A E W 1963 'Dentition in the assessment of age', J Dental Research 42, 255-63.

Mulholland, H 1970 'The microlithic industries of the Tweed Valley', Trans Dumfries Galloway Natur Hist Antiq Soc 47, 81-110.

O'Connor, T 2000 The Archaeology of Animal Bone. Sutton Publishing, Stroud.

Ortner, D J \& Putschar, W G J 1981 Identification of Palaeopathological Conditions in Human 
Skeletal Remains. Smithsonian Institution Press, Washington, DC.

Oswald, A 1997 'A doorway on the past: practical and mystic concerns in the orientation of roundhouse doorways', in Gwilt, A \& Haselgrove, C (eds) 1997, 87-95.

Parker Pearson, M 1996 'Food, fertility, and front doors in the first millenium $\mathrm{BC}$, in Champion, $\mathrm{T}$ C \& Collis, J R (eds) 1996, 117-32.

Parker Pearson, M 1999a 'Food, sex and death: cosmologies in the British Iron Age with particular reference to East Yorkshire', Cambridge Archaeol J 9(1), 43-69.

Parker Pearson, M 1999b The Archaeology of Death and Burial. Sutton, Stroud.

Parker Pearson, M, Mulville, J, Sharples, N \& Smith, H 2001 'Decoding dirt and deposition: the Iron Age broch settlement of Dun Vulan, Outer Hebrides, Scotland', in Collis, J R (ed) 2001, 125-35.

Payne, S 1973 'Kill-off patterns in sheep and goats', Anatolian Studies 23, 281-303.

Petersen, F 1973 'Traditions of multiple burial in Late Neolithic and Early Bronze Age England', Archaeol J 129, 22-55.

Piggott, C M 1948 'The excavations at Hownam Rings, Roxburghshire, 1948', Proc Soc Antiq Scot 82 (1947-8), 193-225.

Piggott, C M 1949 'The Iron Age settlement at Hayhope Knowe, Roxburghshire: excavations, 1949', Proc Soc Antiq Scot 83 (1948-9), 45-67.

Piggott, C M 1953 'Milton Loch crannog I: a native house of the 2nd century AD in Kirkcudbrightshire', Proc Soc Antiq Scot 87 (1952-3), 134-52.

Piggott, S 1953 'Three metalwork hoards of the Roman period from Southern Scotland', Proc Soc Antiq Scot 87 (1952-3), 1-50.

Piggott, S 1958 'Excavations at Braidwood Fort, Midlothian and Craig's Quarry, Dirleton, East Lothian', Proc Soc Antiq Scot 91 (1957-8), 61-77.

Pollock, D 1997 'The excavation of Iron Age buildings at Ironshill, Inverkeilor, Angus', Proc Soc Antiq Scot 127, 339-58.

Pollock, D \& Triscott, J 1980 'Dryburn Bridge, NT 724755, Palisaded enclosure', Proc Prehist Soc 46,369

Price, J \& Cottam, S 1998 Romano-British Glass Vessels: A Handbook. York (= Practical Handbook in Archaeology 14).

Proudfoot, E V W 1978 'Camelon native site', Proc Soc Antiq Scot 109 (1977-8), 112-28.

PSAS 1901 'Donations and purchases for the Museum and Library, with exhibits', Proc Soc Antiq Scot 35 (1900-1), 277.

Ralston, I 1996 'Recent work on the Iron Age settlement record in Scotland', in Champion, T C \& Collis, J R (eds) 1996, 133-53.

Ralston, I 2004 'Scottish roundhouses - the early chapters', Scott Archaeol J, 25, 1-26.

Ramsey, C B, Higham, T, Bowles, A \& Hedges, R
2004 'Improvements to the pretreatment of bone at Oxford', Radiocarbon 46 (1), 155-63.

Red Deer Commission 1981 Red Deer Management: A Practical Book for the Management of Wild Red Deer in Scotland. HMSO, Edinburgh.

Rees, S E 1979 Agricultural Implements in Prehistoric and Roman Britain. Oxford (= Br Archaeol Rep, Br Ser 69).

Rees, T 1998 'Excavation of Culkawk Hill ring-ditch house, Kirriemuir, Angus', Tayside Fife Archaeol J 4, 106-128.

Reitz, E \& Wing, E 1999 Zooarchaeology. Cambridge University Press, Cambridge.

Reynolds, D 1982 'Aspects of later prehistoric timber reconstruction in south-east Scotland', in Harding, D W (ed) 1982, 44-56.

Reynolds, P J 1974 'Experimental Iron Age storage pits: an interim report', Proc Prehist Soc 40, 118-31.

Rideout, J 1996 'Excavation of a promontory fort and a palisaded homestead at Lower Greenyards, Bannockburn, Stirling, 1982-5', Proc Soc Antiq Scot 126, 199-269.

Rideout, J S, Owen, O A \& Halpin, E 1992 Hillforts of Southern Scotland. Edinburgh (= Scott Trust Archaeol Res).

Ritchie, A 1970 'Palisaded sites in North Britain: their context and affinities', Scott Archaeol Forum 2, 48-67.

Roberts, C \& Manchester, K 1997 The Archaeology of Disease, 2nd Edition. Cornell University Press/ Sutton Publishing Ltd, Stroud.

Roberts, J A 1999 Medieval Skeletal Remains from Dunbar, East Lothian. Glasgow, GUARD report, unpublished.

Roberts, J A 2002 Skeletal Remains from Dryburn Bridge. Glasgow, GUARD report, unpublished.

Roberts, J A, Goodwin, W, Taylor, M \& Duffy, P 2004 Dryburn Bridge, East Lothian: a possible case of leprosy from the Bronze Age. Glasgow, GUARD report, unpublished.

Robertson, A S 1970 'Roman finds from nonRoman sites in Scotland. More Roman 'drift' in Caledonia', Britannia 1, 198-226.

Roy, M 2006 'The Dunbar Iron Age warrior grave', History Scotland 6/2, 7-8.

Russell-White, C J 1995 'The excavation of a Neolithic and Iron Age settlement at Wardend of Durris, Aberdeenshire', Proc Soc Antiq Scot $125,9-27$.

Sealy, J 2001 'Body tissue chemistry and palaeodiet', in Brothwell, D R \& Pollard, A M (eds), Handbook of Archaeological Sciences, 269-79. John Wiley \& Sons, Chichester.

Shepherd, I A G 1986 Powerful Pots: Beakers in North-East Prehistory. University of Aberdeen, Aberdeen.

Sheridan, J A 1997 'Pottery', in Johnston, D A 'Biggar Common, 1987-93: an early prehistoric funerary and domestic landscape in Clydesdale, South Lanarkshire', Proc Soc Antiq Scot 127, 202-23. 
Silver, I A 1969 'The ageing of domestic animals', in Brothwell, D \& Higgs, E (eds) 1969, 283-302.

Starley, D 2000 'Metalworking debris', in Buxton, K \& Howard-Davis, C (eds) Bremetenacum: Excavations at Roman Ribchester 1980, 1989-1990, 337-47. Dorchester (=Lancaster Imprints Ser 9).

Steer, K 1956 'An Early Iron Age homestead at West Plean', Proc Soc Antiq Scot 89 (1955-6), 227-51.

Stevenson, R B K 1939 'Two Bronze Age burials', Proc Soc Antiq Scot 73 (1938-9), 231-3.

Stevenson, R B K 1940 'Short cists in the Parish of Innerwick, East Lothian: (a) Thurston Mains, (b) Skateraw', Proc Soc Antiq Scot 74 (1939-40), $138-45$

Strachan, R 1999 'Excavations at Albie Hill, Applegarthtown, Annandale, Dumfries and Galloway', Trans Dumfriesshire Galloway Nat Hist Antiq Soc 73, 9-15.

Strachan, R \& Dunwell, A 2003 'Excavations of Neolithic and Bronze Age sites near Peterhead, Aberdeenshire, 1998', Proc Soc Antiq Scot 133, $137-71$.

Stuart Macadam, P S 1992 'Porotic hyperostosis: a new perspective', Am J Physical Anthropol 87, $39-47$.

Stuiver, M, Reimer, P J, Bard, E, Beck, J W, Burr, G S, Hughen, K A, Kromer, B, McCormac, G, van der Plicht, J, \& Spurk, M 1998 'INTCAL98 Radiocarbon age calibration 24000-0 cal BP', Radiocarbon 40 (3), 1041-83.

Terry, J 1995 'Excavation at Lintshie Gutter unenclosed platform settlement, Crawford, Lanarkshire', Proc Soc Antiq Scot 125, 369-427.

Triscott, J 1982 'Excavations at Dryburn Bridge, East Lothian', in Harding (ed) 1982, 117-24.

Trotter, M 1970 'Estimation of stature from intact long limb bones', in Stewart, T D (ed) Personal Identification in Mass Disasters, 71-83. Smithsonian Institute, Washington, DC.

Ubelaker, D H 1989 Human Skeletal Remains, Excavation, Analysis, Interpretation. 2nd Edition. Taraxacum Press, Washington.

Wait, G A 1985 Ritual and Religion in Iron Age Britain. Oxford (=Br Archaeol Rep, Br Ser 149].

Ward, G K \& Wilson, S R 1978 'Procedures for comparing and combining radiocarbon age determinations: a critique', Archaeometry 20, 19-32.

Watkins, T 1980 'Excavation of an Iron Age open settlement at Dalladies, Kincardineshire', Proc Soc Antiq Scot 110 (1978-80), 122-64.

Welfare, H 1984 'The southern souterrains', in Miket, R \& Burgess, C (eds) 1984, 305-23.

Whimster, R 1981 Burial Practices in Iron Age Britain. Oxford.

Wickham-Jones, C 1990 Rhum: Mesolithic and Later Sites at Kinloch: Excavations 1984-6. Edinburgh (=Soc Antiq Scot monogr 7).

Young, R \& Humphrey, J 1999 'Flint use in England after the Bronze Age: time for a re-evaluation?', Proc Prehist Soc 65, 231-42. 


\section{Appendix I: Osteoarchaeological Analysis Methodology by Julie Roberts}

\section{Age at death}

In the immature individual, Burial 11, age at death was based on dental development and epiphyseal fusion (Ubelaker 1989; Buikstra \& Ubelaker 1994). In the adult individuals, epiphyseal fusion and, where possible, standards developed for the appearance of the pubic symphysis and auricular surface of the pelvis, and the sternal end of the 4th rib, were used (Lovejoy et al 1985; Iscan \& Loth 1986a; Iscan \& Loth 1986b; Brooks \& Suchey 1990). Age at death was based on molar attrition (Miles 1963) only in conjunction with other methods, or when there was no alternative. This is because tooth wear can vary greatly between populations and individuals depending on lifestyle, diet and genetic factors. Generalized degenerative change was also taken into account, but again this can be unreliable for the reasons cited above. Despite using multiple methods (including dental attrition) wherever possible, in almost all cases the ages at death estimated using methods developed since the time of the original report corresponded to those originally given by Harman, based on dental attrition alone.

\section{Sex}

Estimations of sex were based where possible on pelvic and cranial morphology (Buikstra \& Ubelaker 1994). Where these elements were absent or in too poor a condition to be of use, a probable sex was assigned based on the sizes of the articular surfaces of the long bones (Bass 1995). Sexually dimorphic features do not fully develop until puberty, and as yet there are no standards for determining the sex of juveniles considered acceptable by most osteologists (Buikstra \& Ubelaker 1994).

\section{Metric data}

Cranial measurements were taken in accordance with those outlined in Standards for Data Collection from Human Skeletal Remains (Buikstra \& Ubelaker 1994). Related cranial and facial indices were calculated (after Bass 1995). Where any intact long bones were preserved, living stature was estimated using the formulae devised previously (Trotter 1970). Where preservation allowed, standard measurements of the proximal shafts of the femora and tibiae were made in order that platymeric and platycnemic indices could be calculated (standards used were after Bass 1995).

\section{Non-metric traits}

Non-metric traits are skeletal variants that cannot be measured on a metric scale, but are simply recorded as being present or absent. They are thought to be genetically or environmentally determined, and in some cases they have been linked to specific activities or occupations (Kennedy 1989). The significance of non-metric traits is debateable, but they are generally used to compare differences between population groups. Traits were recorded with reference to those compiled previously (Berry \& Berry 1967; Finnegan 1978).

\section{Pathology}

The recognition of specific diseases is often dependent on the whole of the skeleton being present in order that the character and distribution of the lesions throughout the body might be observed. Even in a relatively complete skeleton, however, lack of pathology does not necessarily indicate a healthy individual. Infectious diseases may cause death quickly before bony manifestations have had time to develop, and many illnesses or traumatic injuries that might ultimately be fatal, do not affect the skeleton at all.

All elements from each burial were examined for evidence of pathology and where possible lesions were classified according to cause (Ortner \& Putschar 1981; Roberts \& Manchester 1997; Aufderheide \& Rodriguez-Martin 1998). Differential diagnosis of pathological conditions was particularly difficult in the case of the more poorly preserved Iron Age skeletons. Where there were a sufficient number of elements, for example with the dentition and the vertebrae, disease frequency rates were calculated and limited comparisons were made between the Bronze Age and the Iron Age groups. 